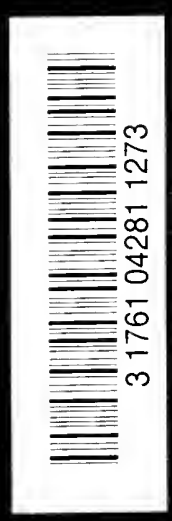

ic

4 



INTERNATIONAL LAW AND DIPLOMACY OF THE RUSSO-JAPANESE WAR 
The $1 \times 1$ is. 


\title{
THE
}

\section{INTERNATIONAL LAW}

AND DIPLOMACY

OF THE

\section{RUSSO-JAPANESE WAR}

\author{
By \\ AMOS S. HERSHEY, Ph. D. \\ PROFESSOR OF POLITICAL SCIENCE AND INTERNATIONAL LAW \\ IN INDIANA UNIVERSITY
}

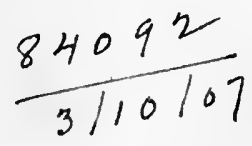

Dew 鼠art

THE MACMILLAN COMPANY LONDON: MACMILLAN छ CO., LTD.

1906

All rigbts reserved 
Copyright, 1906

By AMOS S. HERSHEY

THE HOLLENBECK PRESS

INDIANAPOLIS, INDIANA 
To O. F. H.

THE COMRADE OF MY YOUTH 


\section{Digitized by the Internet Archive in 2007 with funding from Microsoft Corporation}




\section{PREFACE}

In view of the importance of the issues involved and the general interest manifested in the subject, perhaps no apology is needed for the appearance of a volume which aims to be a fairly complete history, from the point of view of International Law and Diplomacy, of the RussoJapanese War.

This great conflict not only aided in the solution of many disputed questions in International Law, but it also gave rise to a number of new precedents and controversies which will materially affect the future conduct of international affairs. It furnished a particularly interesting and important field for the application of those principles governing the rights and duties of neutrals, which are of comparatively recent origin, and to the growth of which the United States has largely contributed. Certain of the rules or customs based upon these principles are still in process of formation, or have not as yet been fully established by the general practice of nations; others are perhaps no longer observed, and are, therefore, of doubtful or waning validity.

International Law is in a state of constant growth and decay. Its rules are the result of international practice which, although based upon fundamental principles, vary in different times and under different circumstances. The usages observed during the Russo-Japanese War may serve to strengthen such customs as are in a stage of imperfect development, or to weaken still further such as are in a state of decay. In any case, they are an index to the present condition of international morality. 
It is hoped that this treatment of the subject may have interest for the general reader as well as for the specialist, and that it may be regarded as a contribution to history as well as to International Law. To this end the material has been cast, wherever practicable, in narrative form. Each chapter, though a separate study, is strictly subordinated to the proportions of the work as a whole.

The present volume has grown out of a series of eight articles contributed to The Green Bag, from May to December, inclusive, 1904. These have, however, been recast and enlarged, and a number of chapters, entirely new, have been added. Chapter 12 is (with slight changes) identical witl a paper which may be found in Vol. II of the Proceedings of the American Political Science Association ( 1905 ).

The author acknowledges his indebtedness to the many publicists whose works have been consulted in the preparation of this volume. The extent of his obligations may be seen in the numerous footnotes. To these footnotes points of minor interest and importance have been relegated, together with references to documents and authorities. They contain fairly complete bibliographies bearing on important principles and controversies, and it may be noted that these bibliographies include references to Continental as well as to Anglo-Saxon authorities.

Two excellent and important works, which appeared during the course of the war, have been of such exceptional service that special mention should here be made of them. These are the "Russo-Japanese Conflict," by K. Asakawa, and "War and Neutrality in the Far East," by T. J. Lawrence.

In conclusion, the author wishes to make public acknowl- 
edgment of his great indebtedness to his friend and colleague, Professor Samuel Bannister Harding, whose advice and assistance in the preparation of this volume have been invaluable; and to Dr. Dudley Odell McGovney, who kindly read the manuscript and offered a number of helpful suggestions.

Bloomington, Indiana, Nov. 17, 1906. 



\section{CONTENTS}

PAGE

Preface $\ldots \ldots \ldots \ldots \ldots \ldots \ldots \ldots \ldots \ldots \ldots \ldots \ldots \ldots \ldots$, vii

\section{INTRODUCTORY}

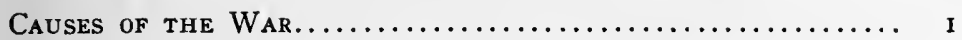

\section{CHAPTER I}

The Outbreak of War and the Alleged Violation of Korean NeUtraltty $\ldots \ldots \ldots \ldots \ldots \ldots \ldots \ldots \ldots \ldots \ldots \ldots \ldots \ldots \ldots, 62$

\section{CHAPTER II}

The Conduct of the United States in Respect to its Neutral Rights and Duties............................. 78

\section{CHAPTER III}

The Construction, Sale, and Exportation by Neutrals of WarShips, Submarine Boats, and other Vessels Intended for Belligerent Service............................... 9i

\section{CHAPTER IV}

War Correspondents, Wireless Telegraphy, and Submarine Mines $\ldots \ldots \ldots \ldots \ldots \ldots \ldots \ldots \ldots \ldots \ldots \ldots \ldots \ldots \ldots \ldots \ldots \ldots \ldots \ldots$

\section{CHAPTER V}

Russian Seizures of Neutral Merchantmen-the Right of Visit and Search and the Allegged Right of Sinking Neu-

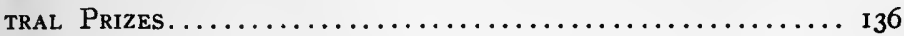

\section{CHAPTER VI}

Questions Relating to Contraband of War................ i6o

\section{CHAPTER VII}

The Voyage of the Baltic Fleet, and the Rights and Privileges of Belligerent Armed Vessels in Neutral Ports and WATERS 


\section{CHAPTER IX}

The Hay Note and Chinese Neutraltty.............. 246

\section{CHAPTER X}

Russian and Japanese Rules of Warfare...............269

\section{CHAPTER XI}

The Relations of the Belligerents with Each Other........ 295

CHAPTER XII

The Relations between England and the United States as Affected by the Far EAStern Question and the War..... 325 CHAPTER XIII

The Treaty of Portsmouth......................... 340

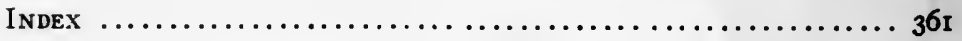




\section{INTERNATIONAL LAW AND DIPLOMACY \\ OF THE}

\section{RUSSO-JAPANESE WAR}

\section{INTRODUCTORY \\ The Causes of the War}

In his history of the Hannibalic War, Polybius carefully distinguishes between the real or fundamental causes of the struggle and the overt acts or events leading up to that great conflict. He justly remarks that we should look for real causes in the "motives which suggested such action and the policy which dictated it."1 But in order to explain fully the fundamental causes of the Russo-Japanese War, it would be necessary to analyze carefully the foreign policies of Russia and Japan and to investigate the motives which suggested these policies. This would involve an exposition of Russian and Japanese political and economic aims and ambitions as illustrated by a complete history of Russian and Japanese expansion, more particularly of the Russian advance to the Pacific and the repeated efforts of Japan to obtain a preponderance of influence in, if not a positive control over, the affairs of Korea. For such an exhaustive discussion the writer has neither the requisite knowledge nor sufficient space at his disposal. The reader of this volume must, therefore, be content with a brief sketch or outline of the underlying issues at stake between Japan and Russia.

${ }^{1}$ Polybius (Shuckburgh's trans.) III, 6. 
For Japan, except possibly in Korea, these issues appear to be economic rather than political in their nature. They are to be found in the "enormous increase of her population"; the "immense growth of her trade and industries"; the slow progress of her agriculture, which is "no longer able either to support her increased population or to produce enough raw articles for her manufactures"; the consequent need of new sources of supply, as well as an outlet or field of colonization and economic enterprise for her surplus population; and finally, the need of "an increased importation of raw material and foodstuffs and an increased exportation of manufactures."2

Japan's interests in China-probably the most important stake in this war-also seem to be primarily economic rather than political. ${ }^{3}$ They are apparently based on a desire for trade advantages, the gaining of which involves, under present conditions, the maintenance of the principle of the open door in China, or the policy of equal economic opportunity for all nations. This in turn involves, as a means to that end, the preservation of the territorial sovereignty or integrity of China; for if that country be dismembered or partitioned into "spheres of interest" or "influence," it might eventually fall a prey to the systematic commercial exploitation and exclusive protective systems of the several Powers exercising political influence or control in the regions acquired by them.

The interests of Russia in the Far East, on the other hand, appear to be primarily political rather than economic, and are, therefore, less vital than those of Japan. Russia is still

2 The above citations are from the Introduction to Dr. Asakawa's excellent work entitled The Russo-Japanese Confict, pp. I-8, passim.

They are probably political only in a negative sense, $i$. $e$., as opposed to aggressive political designs on the part of any other Power.

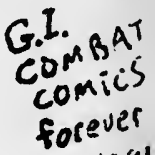


essentially in the agricultural stage of her development, and, in an economic sense, she is largely sufficient unto herself. Speaking broadly, it may be said that she produces what she consumes and consumes what she produces. Her "economic interests are, even in Manchuria, rather for her glory as a great expanding empire than for any imperative need of trade and emigration in that particular part of her Asiatic dominion; while similar interests of Japan, primarily in Korea and secondarily in Manchuria, are vital, as they are essential for her own life and development as a nation."

A mere glance at the globe will suffice to show how greatly the history of Russian expansion has been influenced by her geographical situation. Ever since the days of Peter the Great, who first discerned the possibilities of the future, the foreign policy of Russia has been largely controlled by a desire to obtain access to the sea in four directions, viz.- - the Baltic Sea, the Black Sea and the Mediterranean, the Persian Gulf, and the Pacific Ocean. Her desire for the control of the Baltic Sea has been but partially realized, owing to the maritime rivalry of England, Germany, and Sweden; after several failures she finally secured a foothold on the Black Sea, but her successive attempts to obtain control of Constantinople and the passageway of the Bosporus and the Dardanelles from the Black Sea to the Mediterranean have been frustrated by the interference of the Powers, more particularly of England, who has also restrained her from ob-

-Asakawa, op. cit., p. 48. The truth of the former part of the above statement is shown by the fact that, while Russia's vested interests in Manchuria are enormous, her commercial success there has been remarkably small. Such apparent success as she obtained in Manchuria was due to the protective and exclusive policy of the Russian Government and to the artificial stimulus which was furnished by the building of railways and the activity of the Russo-Chinese Bank. See recent works on Manchuria, especially Weale, Manchu and Muscovite, passim. 
taining a foothold on the Persian Gulf; and her recent attempt to become the dominant power on the Pacific has been defeated by Japan, the England of the Far East. ${ }^{5}$

The Russian advance across the Ural Mountains into Siberia was begun in the latter part of the sixteenth century under the leadership of the Stroganoffs, a rich and powerful corporation of merchants, which flourished during the reign of Ivan IV. In 158I the Cossack robber outlaw Yermak announced to the Czar the conquest of a new "Siberian Kingdom." In the latter part of the sixteenth century was begun the construction of a line of towns across Siberia, which finally reached the Pacific at Okhotsk in 1638 . This place was too far north, however, to make a really.serviceable port, and the control of the Amur River next became the object of Russian ambition. In the seventeenth century the repeated clashing of the Cossacks and Manchus in this region led to diplomatic negotiations between the Muscovite and the Chinese Governments which resulted in $168 \mathrm{I}$ in the Treaty of Nerchinsk. By this treaty the Russians were excluded from the region of the Amur; and the Argun River and the Stanovoi Mountains were fixed upon as the boundary line between the Empires of China and Muscovy. ${ }^{\circ}$

More than a century and a half passed before another attempt was made to reach the Amur. In 1847 Count Nikolas Muravieff (later known as Count of the Amur or Muravieff Amursky) became Governor of Eastern Siberia. His success in provisioning the Russian Pacific fleet by way of the Amur River during the Crimean War (I854-186I), the re-

\footnotetext{
"For a good general sketch or outline of the history of the "Expansion of Russia," see Rambaud, The Case of Russia.

- For the main provisions of this treaty, see Weale, Manchu and Muscovite, pp. 40-4I. For the text, see De Martens, Nouveau recueil genérale, $\mathrm{t}$. XVII, and part, p. 173 .
} 
pulse of the allied Anglo-French squadron by this Russian fleet in 1854-55, and the defeat of Russian policy in the nearer East as the result of the Crimean War, together with the personal appeals of Count Muravieff, seem to have furnished the arguments which convinced the Russian Government of the importance of the Amur to the interests of Russia, and that the line of least resistance to the realization of Russian dreams of expansion lay in the direction of the Pacific. In I 857 Count Muravieff, armed with full discretionary powers as the result of a visit to St. Petersburg, began a systematic advance which resulted in the Treaty of Aigun $^{7}$ in May, I858. China being then at war with England and France, the Chinese frontier authorities consented to the cession to Russia of the left bank of the Amur, or the vast territory north of this river as far as the Ussuri, and of both banks from thence to its mouth. The Treaty of Aigun, which had not been signed by the Chinese Central Government, was replaced by the Treaty of Peking in November, I $860 .^{8}$ This important treaty, the terms of which were highly favorable to Russia, was secured by the skillful diplomacy of General Ignatieff, who had won the favor of the Chinese Government by acting as mediator between China and the allies. It fixed the boundaries of Manchuria as they nominally existed at the outbreak of the Russo-Japanese War. Russia thus acquired, in addition to the left bank of the Amur, the region on the Pacific lying east of the Ussuri and the Amur rivers bordering on the Sea of Japan and extending as far south as Korea. ${ }^{9}$ Russia had obtained possession of Maritime Manchuria, which was to furnish her with

\footnotetext{
'De Martens, op. cit., t. XVII, Ist pt., p. I.

- De Martens, op. cit., and pt., p. 18r.

- For details, see Weale, op. cit., pp. 51-52.
} 
a port on the Pacific (Vladivostok) in a much more temperate region than any she had hitherto occupied, and had also completely shut China off from direct access to the Sea of Japan. In I861 a Russian man-of-war took possession of the Japanese islands of Tsushima in the Korean straits, but it was obliged to withdraw at the instance of the British Minister. In 1875 the long island of Sakhalin, for many years ( and Russia, was formally surrendered to Russia by Japan in return for the sterile Kurile islands.

The period between $\mathrm{I} 860$ and $\mathrm{I} 890$ was devoted to colonization and the promotion of commerce in these newlyacquired provinces-Amur and Primorsk. The visit of the Czarevitch in the Far East in I89I seems to have had a very important influence upon the course of subsequent events. It brought St. Petersburg to a specific knowledge of conditions in the Far East; led to a realization, on the part of the Russian Home Government, of the rising importance of Japan as a Pacific power; and created a conviction of the necessity for Russia to increase and consolidate her power in the Far East if she desired to maintain and strengthen her position in that quarter of the globe. The Czarevitch also in I89I cut the first sod, near Vladivostok, for the great TransSiberian Railway.

The unexpected outcome of the Chino-Japanese War in 1894-95 afforded Russia an opportunity of at once administering a severe blow to Japan and of ingratiating herself with China. The Treaty of Shimonoseki ${ }^{10}$ between these

${ }^{10}$ For the text of the treaty, see U. S. House Documents, 54th Congress, Ist session, Vol. I, pp. 200-203. It is also printed in the Appendix to Beveridge, Russian Advance. For the French text, see Appendix to La Guerre Sino-Japonaise, by N. Ariga. 
two belligerents, signed on April I 7, I895, provided, among other things, for the absolute independence of Korea, the cession to Japan of the Liao-tung Peninsula, Formosa, the Pescadores, and an indemnity of 200,000,000 taels. The Japanese control of the Liao-tung Peninsula and Port Arthur (the key to Peking), Manchuria, and Korea, meant a death blow to Russia's hopes of expansion southward and of thus obtaining one or more ice-free ports on the Pacific. It is, therefore, not at all surprising that Russia acceded to $\mathrm{Li}$ Hung Chang's appeal for intervention, although the motives of France and Germany in joining that intervention are less clearly discernible. The result of the interchange of views between Russia, Germany, France, and England which followed was that the Russian, French, and German representatives at Tokio joined, in the latter part of April, in a "friendly recommendation" to the Japanese Government, to the effect that the "contemplated possession of the Liao-tung Peninsula by Japan would not only constitute a constant menace to the capital of China, but would also render the independence of Korea illusory, and thus jeopardize the permanent peace of the Far East." Accordingly, "in a spirit of cordial friendship for Japan," they counselled the Japanese Government "to renounce the definitive possession of the Liao-tung Peninsula." 11

Meanwhile, the three intervening Powers, by the augmentation and concentration of their Eastern fleets, made a display of overwhelming force, "Russia going even so far as to prepare the army contingents in the Amur region for quick mobilization." ${ }^{12}$ The Japanese Government, in view of the

"From the Russian note to the Japanese Government. Reprinted by Lawrence, War and Neutrality in the Far East (2nd ed.), p. Ir.

${ }^{12}$ Asakawa, p. 75. 
exhaustion of its resources, and being urged by the British Minister "to make to the susceptibilities of Europe all concessions compatible with the dignity and permanent interests" of Japan, ${ }^{13}$ decided, early in May, to relinquish, for an additional indemnity of $30,000,000$ taels from China, all of the Liao-tung Peninsula. On May 10, 1895, the Mikado issued an Imperial Rescript, countersigned by all his ministers, announcing that, "out of regard for peace" and a disinclination to cause suffering to his people, or "to impede the progress of the national destiny by embroiling the Empire in new complications," he had decided to accept "the advice of the friendly Powers," and had commanded his government "to negotiate with the Chinese Government respecting all arrangements for the return of the particular districts." ${ }^{14}$ In accordance with this proclamation, a convention between China and Japan for the retrocession of the Liao-tung Peninsula was signed at Peking on November 8, 1895, just six months after the exchange of the ratification of the Treaty of Shimonoseki. ${ }^{15}$

The retrocession of the Liao-tung Peninsula to China, although bitter medicine at the time, proved for Japan a blessing in disguise. It marks a turning point in her history, more particularly in her relations with Russia. Although it can hardly be considered a fundamental cause of the Russo-Japanese War (which was sooner or later inevitable,

${ }^{13} \mathrm{M}$. de Blowitz to the London Times, May 3, 1895, p. 5. Cited by Asakawa, p. 76.

${ }^{16}$ This proclamation is printed in full in Hosie, Manchuria, pp. 41-42, and by Beveridge, Appendix. For the French text, see Ariga, La Guerre Sino-Japonaise, Appendix VI.

${ }^{2 s}$ Japan made a strong effort to secure from China a promise that under no circumstances would the latter voluntarily cede the Liao-tung Peninsula or any part thereof to any other Power; but this attempt is said to have been defeated by the action of the three allies. 
in any case), yet it brought Russia face to face with Japan in Korea and greatly hastened the outbreak of the struggle. If Japan had entertained any delusions regarding the ultimate designs of Russia or the real character of European diplomacy, these illusions now vanished forever, and Japan realized, as she never had before, the necessity of straining every nerve to increase and strengthen her naval and military arms to the utmost, if she desired to assume a leading rôle in the affairs of the Orient, or perhaps even to maintain her independence. As Dr. Asakawa testifies:" "Japan suddenly awoke to an absorbing desire which left her little room for the question of revenge. It became to her as clear as daylight that the new position she had acquired in the Orient by her victory over China could be maintained, and even her independence must be guarded, only by an armament powerful enough to give her a voice among the first Powers of the world. If she would not retire within herself, and finally cease to exist, she must compete with the greatest nations, not only in the arts of peace, but also in those of war. Moreover, a far vaster conflict than she had ever known in her history, excepting the Mongol invasion of the thirteenth century, was seen to be awaiting her." From this time on, the budgets of the Japanese Government show a great increase in army and naval expenditures. ${ }^{17}$ Subsequent events only tended to make the Japanese Government and people more resolute in their efforts in this direction.

In I89 I Russia had begun, at a tremendous cost, the construction of the great Trans-Asiatic Railroad across Siberia to Vladivostok. But the route from Lake Baikal to Vladivostok through the Amur province north of the Amur River

${ }^{16}$ The Russo-Japanese Conflict, pp. 79-80.

${ }^{17}$ See table in Asakawa, p. 80. 
proving well-nigh impossible, it was resolved to run the railway through Manchuria by a more direct and practicable route. By her successful intervention in the Chino-Japanese War, Russia had placed China under a debt of fear and gratitude, and this debt was greatly increased by the guarantee by the Russian Government of a 4 per cent. loan to China, on very liberal terms, ${ }^{18}$ of $400,000,000$ francs, the interest of which was guaranteed by the Russian Government without security. Ostensibly to facilitate the execution of this loan, but really to promote Russian commercial and political designs in Eastern Asia, the Russo-Chinese Bank was organized, in 1895 , with Prince Uktomsky as President. The Chinese Government was induced to contribute 5,000,000 taels toward the capital of the bank, and by the end of the year 1896 Prince Uktomsky had obtained valuable concessions or privileges from China in the way of important railway and telegraph franchises, the receipt of tax returns, management of local finances, coining privileges, etc. ${ }^{19}$

In the meantime, Russian diplomacy appears to have been active through its regular official channels. On September 30, 1896 , the so-called "Cassini Convention" was ratified at Peking. This secret agreement, which has been the subject of considerable controversy (its existence having been offcially denied by the Russian Government), conceded to Russia privileges of the most important nature "as a re-

${ }^{13}$ This loan was issued principally from Paris in July, 1895 , and was intended to cover one-half of China's indemnity to Japan. It was issued at $941 / 8$, bore 4 per cent. interest, and was payable in thirty-six years. The other half $(£ 16,000,000)$ was supplied by British and German capitalists at 5 per cent. interest. See Asakawa, pp. 83-84.

${ }^{10}$ On the Russo-Chinese Bank, see Cordier, III, pp. 310-312, and Asakawa, p. 85 . 
sponse to the loyal aid given by Russia in the retrocession of the Liao-tung and its dependencies." These included: (I) The right to prolong the Siberian Railway into Chinese territory across the northern part of Manchuria to Vladivostok. The control of all railways built by Russia in northern Manchuria was to be placed in the hands of Russia for thirty years, at the end of which time China was to be allowed to redeem them, although the manner of such redemption was to be "left for future consideration." (2) If China should find it "inconvenient" to build the railroad in contemplation from Niu-chwang to Mukden, she was to allow Russia to provide the necessary funds, but was to be allowed to redeem this road at the end of ten years. (3) The Russian railways in Manchuria were to be "protected" by the Chinese local, civil, and military authorities; but, "owing to the fact that the said railways will pass, for the greater part, through barren and sparsely inhabited territory, in which it will be difficult for the Chinese authorities to be always able to grant the necessary protection and aid, Russia shall be allowed to place special battalions of horse and foot soldiers at the various important stations for the better protection of the railway property." (4) Russians as well as Chinese were to be permitted hereafter to exploit and open any of the mines in northern Manchuria. (5) Should China desire to reform her army organization in the said province in accordance with the Western system, she was to be permitted to engage Russian military officers for that purpose.

Since "Russia has never possessed a seaport in Asia which is free from ice and open the year round," and since if "there should suddenly arise military operations on this Continent, it will naturally be difficult for the Russian Eastern Seas and Pacific Fleets to move about freely and at pleasure," China 
declared herself "willing to lease temporarily to Russia the port of Kiao-chau in the province of Shan-tung, the period of such lease being limited to fifteen years. . . . But, should there be no danger of military operations, Russia shall not enter immediately into possession of the said port, or hold the important points dominating the port, in order to obviate the chance of exciting the jealousy and suspicions of other Powers." (7) China was to properly fortify the Liao-tung ports of Port Arthur and Talien-wan "with all haste," "in order to provide against future dangers;" and Russia was to lend all necessary assistance "in helping to protect these two ports," and was not to "permit any foreign Power to encroach upon them." China, on her part, also bound herself "never to cede them to another country, but if, in future, the exigencies of the case require it, and Russia should find herself suddenly involved in a war," China consented "to allow Russia temporarily to concentrate her land and naval forces within the said ports, in order better to enable Russia to attack the enemy or to guard her own position." If, however, there was no danger of military operations, China was to retain entire control over the administration of these ports. ${ }^{20}$

${ }^{20}$ For the text of the "Cassini Convention," see the appendices to Weale, Re-Shaping of the Far East, and Beveridge, Russian Advance. As stated in the text, the existence of this Convention was denied by Russia and it is characterized by some writers as "apocryphal." The document may be unauthentic in some particulars, but its substantial truth appears now to be generally admitted and the fact of its existence seems to be borne out by subsequent events. For some convincing arguments on this head, see Asakawa, pp. $90 \mathrm{ff}$.

Earlier in the same year ( 1896 ) a secret treaty of alliance between China and Russia appears also to have been concluded. The Russian text has never been published, but Asakawa (pp. 85-87) gives the following abstract from a Japanese source: "It was agreed, in secrecy, that, if Russia should come into conflict with other Asiatic Powers, she 
At about the same time (September, I896) there was concluded an open agreement between the Chinese Government and the Russo-Chinese Bank providing for the construction of a railway through Manchuria connecting the Trans-Baikal and South Ussuri lines of the Siberian railway system. This "Agreement," together with the "Statutes" of the Railway promulgated by the Czar, provided for the organization of the Chinese Eastern Railway Company under the management of a board whose nominal head was the Chinese Minister at St. Petersburg, but whose real head, the vice-president, was under the supervision of the Russian Minister of Finance. The general terms of the "Agreement" were that the shareholders should be Russians and

should be allowed to make free use of any port or harbor on the Chinese coast, and, in case of urgent need, levy troops from among the Chinese people. If a protest should be made by other Powers, China should answer that she was powerless to resist Russian demands. . . . In view of the great disadvantages of the ice-bound naval harbors of Russia, China agreed to allow her in time of peace a free use of Port Arthur, or, if the other Powers should object, of Kiao-chau. If the latter should be found inadequate, Russia might choose any harbor on the coast of Kiang-su and Che-kiang. If, on the other hand, China should be at war with another Power, Russia should endeavor to effect a compromise between the belligerents, and, if the effort should fail, it should be the duty of Russia openly to assist China and thereby strengthen the alliance between the two Powers. . . . If a war should arise between Russia and Japan concerning Korea, China should allow Russia to send troops toward the Yalu, so as to enable them to attack the western boundary of Korea."

Cordier (Histoire des relations de la Chine avec les puissances occidentales, III, pp. 347-48) is of the opinion that the Cassini Convention can not be considered as an official or authentic document. He thinks it is a hybrid which contains clauses borrowed from two documents: (I) the convention with the Russo-Chinese Bank relating to the Manchurian railway, signed in September, I896; and (2) the secret treaty of alliance of March-April of the same year. This view is adopted by M. Rey in the Revue Générale de Droit International Public for 1905, p. 225. 
Chinese only; that the railway should be begun within twelve months and completed within six years; that, on the expiration of eighty years from the completion of the line, the railway, together with all its property, should pass, without payment, to the Chinese Government, which was not to be held responsible for any losses which the company might sustain during that period; and that the Chinese Government was to have the right, at the expiration of thirty-six years from its inauguration, to take over the railway on due payment, such payment to include the actual cost thereof, together with all interest thereon. The "Agreement" also contained a provision for the protection of the railway and its employees by the Chinese Government, and the "Statutes" provided for the policing of the lands assigned to the road and its appurtenances by "police agents appointed by the company." "21 "It was also provided that during the eighty years of Russian management, all commodities carried between China and Russia by the railway should pay in China duties one-third less than the ordinary import and export duties in that Empire,-a provision hardly reconcilable with the open door principle, and explicitly contrary to the principles proposed by the United States to the Powers two years later." 22

The road to Vladivostok through Manchuria was now open, and, in accordance with the above agreement, the

"In these police agents, Asakawa (p. 98) discerns the origin of the famous "railway" or "frontier guards" whose existence later became an important problem in connection with the Russian evacuation of Manchuria.

"Asakawa, p. 99. For the substance of the "Agreement," see Hosie, Manchuria, pp. 43-44, and Asakawa, pp. 96 ff. The "Statutes" are printed in the Appendix to Beveridge, Russian Advance, pp. $473 \mathrm{ff}$., and in Weale, Re-Shaping of the Far East, II, pp. 444 ff. App. D. 
Chinese Eastern or Manchurian Railway was begun in August, r897. But Vladivostok is ice-bound several months of the year, and Russia longed for a port which was ice-free the whole year round. An opportunity for acquiring such a port and at the same time greatly strengthening her strategic position on the Pacific presented itself in March, I898, when Germany secured a 99-year lease of the bay and port of Kiao-chau, ${ }^{23}$ along with exclusive mining and railway privileges in the province of Shan-tung, as indemnity for the murder of two German Catholic missionaries at the hands of a Chinese mob during the previous year. A precedent was thus set which went far to palliate, if, indeed, it did not tend to justify a similar seizure on the part of Russia. ${ }^{24}$ With the plea that she could not be denied what had been granted to Germany, Russia demanded a lease of Port Arthur and Talien-wan, ${ }^{25}$ and also a concession for a railway between these ports and a point on the Manchurian section of the Trans-Siberian railroad. These concessions were made to Russia by China on March 27, I898, and were followed by the promise of the lease of Wei-hai-wei to Great Britain on April $3^{26}$ of the same year, as a means of "restoring the balance of power in the Gulf of Pe-chi-li," ${ }_{27}$ and by the

${ }^{2}$ The port Tsing-tau at the entrance to the bay of Kiao-chau had been seized by the landing of 600 German marines in November, 1897 . Li-Hung Chang justly characterized this act of brigandage as "a flagrant violation of treaties and of International Law." See Cordier, III, p. 353 .

${ }^{24}$ It is especially worth noting in this connection that Kiao-chau was to have been leased to Russia by the terms of the "Cassini Convention."

${ }^{25}$ Port Arthur was to be open only to Russian and Chinese war vessels, and was to be closed to all the ships of other nations; Talien-wan, on the other hand (with the exception of a portion used for naval purposes), was to be an open port.

${ }^{*}$ The lease was not actually signed until July I, 1898 .

${ }^{2}$ The lease of Wei-hai-wei to Great Britain was approved of by 
French occupation under lease of the Kwang-chau Bay on the southeastern coast of China.

The Central Manchurian Railway, i. e., the southern branch of the Chinese Eastern or Trans-Manchurian Railway, connecting Port Arthur, Dalny, and Niu-chwang with Harbin on the main line, was now built, in accordance with the terms of the agreement of March 27, I898, by which Russia acquired the lease of Port Arthur, Talien-wan, and adjacent parts of the Liao-tung Peninsula. Article VIII of this agreement provided that the procedure sanctioned in I896, regarding the construction of railways by the Chinese Eastern Railway Company across Manchuria, be extended so as to include the construction of this branch line.

The work was interrupted, however, by the Boxer uprising in 1900, which had important results for China and the rest of the world. One of these was the occupation of Manchuria by Russian troops amidst scenes of frightful slaughter. Even the treaty port of Niu-chwang was seized, and placed under the civil administration of Russian authorities on August 5. On August 14, 1900, at a time when the troops of the allies had almost reached Peking, General Groderkoff, then in command of the northern Russian army in Manchuria and Governor-General of the Amur province,

the Japanese Government. It was to remain in the possession of England so long as Port Arthur, which had been leased for twenty-five years (subject to renewal by mutual agreement), remained in the hands of Russia. On these leases, see especially Asakawa, ch. 4, and Beveridge, ch. 9. The latter prints several of the important texts and documents. See also the Appendices to Weale, Re-Shaping of the Far East. See Cordier, III, ch. 20, for the texts in French.

For more detailed information of an official or diplomatic character regarding these occupations and leases, see the British Parliamentary Blue Books on China for 1898-1900, and the U. S. House Documents, 55th Congress, 3 rd session (Foreign Relations, I898), pp. I82 ff. 
wrote to the Minister of War at St. Petersburg: "Fifty years ago Nevelskoy raised the Russian flag at the mouth of the Amur, on its right bank, and laid the foundation for our possessions on that great river. Now, after hard fighting, we have taken possession of the right bank, thus consolidating the great enterprise of annexing the whole of the Amur to Russia's dominions, and making that river an internal waterway and not a frontier stream, whereby free and unmolested navigation of that artery through one of the vastest regions of the Empire has been secured." ${ }^{28}$ By the time the Foreign Legations at Peking had been relieved, the greater portion of Manchuria was occupied by Russian troops.

In order to allay the apprehensions of the Powers, the Russian Government issued a Circular Note to the Powers on August 28, $1900,{ }^{29}$ in which it was explained that the military occupation of Manchuria was purely "temporary" in its nature and "had been solely dictated by the absolute necessity of repelling the aggression of the Chinese rebels, and not with interested motives, which are absolutely foreign to the policy of the Imperial Government." It was furthermore declared that as soon as the pacification of Manchuria shall have been attained and the necessary measures taken for the protection of the railway, "Russia would

${ }^{28}$ Cited by Asakawa, p. I45.

20 In a Circular Note to the Powers on July I3, I900, Russia had laid down the fundamental principles which she considered necessary for the maintenance of a permanent peace in the Far East. These were: (I) harmony between the Powers having interests in China; (2) the exclusion of all idea of a partition of the Celestial Empire; (3) the preservation of the governmental régime formerly existing in China; and (4) the reëstablishment by common action of the legitimate Central Government at Peking. $C f$. the response of Russia to Japan on June 28, 1900, cited by Baron Suyematsu in the Nineteenth Century for September, I904, p. 345. See also Suyematsu, The Risen Sun, pp. 42-43. 
not fail to withdraw her troops from Chinese territory, provided that the action of the other Powers does not place any obstacle in the way of such a measure."30 Similar assurances were subsequently given by leading representatives of the Russian Government. ${ }^{31}$

In spite of these assurances, Russia remained in military occupation of Manchuria. The Russian troops withdrawn from Peking were sent to Manchuria and large naval reinforcements were dispatched to the Far East. A military force of twelve thousand railway guards was established for the protection of the Manchurian railways, and an agreement concluded in November of the same year (1900), between a representative of Admiral Alexieff and the Tartar General, Tsêng-chi, of Mukden, known as the AlexieffTsêng Agreement, ${ }^{32}$ provided that the Chinese should resume the civil government of Feng-tien (Sheng-king), the southern province of Manchuria, on the following conditions: that the Chinese soldiers be disarmed and disbanded

${ }^{30}$ The italics are the author's. See Parliamentary Blue Book on China, No. 1, No. 256. Similar assurances that Russia had no territorial designs in China were given to the United States. See $e$. g., U. S. House Documents of 56th Congress, and session (Foreign Relations, 1900), pp. 304, 372, 380 .

To the American representative at St. Petersburg, Count Lamsdorff volunteered the statement, in the most positive terms, that Russia had no intention whatever of acquiring or retaining "a single inch of territory in either China or Manchuria." Ibid., p. 372.

${ }^{31}$ E. g., by Count Lamsdorff, on October 25 , to the Russian representatives abroad, and by General Kuropatkin to the Governors-General of the Amur and Kwau-tung provinces. Cited from a Japanese source by Asakawa, p. 152, note.

${ }^{82}$ For the text of this agreement, see Asakawa, pp. I66-67, and Blue Book on China, No. 2 (1904), p. 3. Similar agreements described as modus vivendi appear to have been concluded in the other provinces of Manchuria between the Chinese and Russian authorities. See Russian Official Messenger of April 6, I901, cited by Asakawa in note on p. I68. 
and all munitions of war be handed over to the Russians; that all forts and defences in Feng-tien not occupied by the Russians be dismantled; that "Niu-chwang and other places now occupied by the Russians be restored to the Chinese civil authorities when the Russian Government is satisfied that pacification of the provinces is complete"; that law and order be maintained by the Chinese local police under the Tartar general, who, in case of emergency, was to apply for Russian reinforcements to the Russian Political Resident stationed at Mukden.

Although this agreement had not been ratified either at St. Petersburg or Peking, its contents, as published in the London Times on January 3, I90I, caused general astonishment in the diplomatic world, and a further report in the beginning of February that Russia was urging China to ratify the agreement led Japan, Great Britain, Germany, and the United States to make strong representations to China on this subject. ${ }^{33}$

Before any of the protests of the Powers had reached Peking, Count Lamsdorff had, however, on February 6, explained matters to Sir Charles Scott, the British Minister at St. Petersburg. He denied that "Russia had concluded or was engaged in concluding, with China, a convention or permanent arrangement which would give Russia new rights and a virtual protectorate in Southern Manchuria"; although he admitted that "the Russian military authorities who had been engaged in the temporary occupation and pacification of that province had been directed, when reinstating the Chinese authorities in their former posts, to arrange with the local civil authorities the terms of a modus

${ }^{38}$ See British Blue Book on China, No. 2 (I904), Nos. 8, I2, I3, I9. 
vivendi between them for the duration of the simultaneous presence of Russian and Chinese authorities in Southern Manchuria, the object being to prevent the recurrence of disturbances in the vicinity of the Russian frontier, and to protect the railway from the Russian frontier to Port Arthur." He also admitted that "some of the details of the proposed modus vivendi had been sent for consideration to St. Petersburg," but he insisted that no convention or arrangement with regard to Manchuria had been concluded with the Central Government of China. He assured the British ambassador that the Czar had no "intention of departing in any way from the assurances which he had publicly given that Manchuria would be entirely restored to its former condition in the Chinese Empire as soon as circumstances admitted of it."

This communication closed, however, with the following ominous statement: "When it came to the final and complete evacuation of Manchuria, the Russian Government would be obliged to obtain from the Central Government of China an effective guarantec against the recurrence of the recent attack on her frontier and the destruction of her railway, but had no intention of seeking this guarantee in any acquisition of territory or of an actual or virtual protectorate over Manchuria, the object being simply to guarantee the faithful observance in the future by China of the terms of the agreement which she had been unable to fulfill during the disturbance." ${ }^{\text {34 }}$

Within a few weeks after this statement by Count Lamsdorff, it was learned that the Russian Government was pressing China hard for a new agreement providing for "an ef-

${ }^{34}$ Blue Book on China, No. 2 (1901), and China, No. 2 (1904), No. II. 
fective guarantee" such as Russia desired. On February 28, I90I, there was published in the London Times the substance of an agreement between Count Lamsdorff and Yang-yu (known as the Lamsdorff-Yang-yu Convention), ${ }^{35}$ the Chinese representative at St. Petersburg. According to the supposed terms of this agreement (of which there exists no authentic text), the Czar agreed to "restore" the whole of Manchuria to China on the following conditions: (I) that a corps of the railway guards provided for by the Manchurian Railway Agreement be retained until order shall be restored and until China shall have fulfilled certain obligations set forth in the last four articles of the convention; (2) that China agree "not to organize an army until the (Manchurian) railway is completed and opened to traffic", and that "when military forces are eventually organized, their numbers shall be fixed in consultation with Russia"; (3) that the importation of arms and munitions of war into Manchuria be prohibited; (4) that "China shall dismiss from office all Generals-in-Chief (Tartar Generals) and high officials whose actions conflict with friendly relations, and who are denounced for that reason by Russia. China may organize mounted and foot police in the interior of Manchuria, but their numbers shall be fixed in consultation with Russia"; (6) that "no subject of another Power be employed to train naval or military forces in the Northern Provinces (i.e., the provinces in North China)"; (7) that "without the consent of Russia, China shall not concede mining, railway, or other privileges to another Power, in the countries adjoining Russia, that is to say, in Manchuria,

${ }^{25}$ For the supposed text of this convention, see Asakawa, pp. 174-76. For the various Chinese versions, see Blue Book on China, No. 2 (1904), Nos. 14, 25, and 42. 
Mongolia, Tarbogati, Ili, Kashgar, Yarkond, Khoten, etc. China shall not herself construct a railway in those countries without Russia's consent;" (8) that no leases of land in Manchuria, outside of Niu-chwang, be granted to the subjects of other Powers. The last four articles relate to the payment of the Chinese indemnity due to Russia, payment of damages for destruction of railway property, etc., during the Boxer uprising, the whole or part of which indemnities might be set off against privileges of other kinds.

Upon the appeal of the Emperor of China to the Powers declaring that "it was impossible for China alone to incur the displeasure of Russia by remaining firm," Great Britain and Japan protested vigorously against the conclusion of such a separate agreement with Russia; "for such an act was contrary to the principle of solidarity which then united the Powers, and an individual convention with a Power would materially lessen the capacity of China to meet her obligations toward all the Powers." ${ }^{\prime 3}$ As a result of these protests, China refused to sign the convention even in a form somewhat modified in her favor; and on April 6, I901, it was officially announced in Russia that owing to the publication in the foreign Press of all sorts of false reports of the alleged treaties with China, and owing to the serious obstacles that had apparently been put in the way of China as regards the conclusion of an agreement with Russia serving as a "starting point" toward the restoration of Manchuria to China, "it had been found impossible immediately to take the measures contemplated for the gradual evacuation of Manchuria." The negotiations had therefore been aban-

*Asakawa, p. 178. Germany suggested, Great Britain and Japan seconding the suggestion, that China should refer the matter to the Conference of the representatives then in session at Peking. 
doned. "With regard to the question of the complete and final restitution of this territory to China," it was declared: "it is evident that it can only be accomplished after a normal state of affairs has been reëstablished in the Chinese Empire, and a Central Government has been secured in the capital, independent and sufficiently strong to guarantee Russia against the renewal of the disturbances of last year. While maintaining the present temporary form of government in Manchuria, with the object of insuring order in the neighborhood of the vast Russian frontier, but remaining unalterably true to their original programme, as repeatedly formulated, the Imperial Government will quietly await the further progress of events.",37

It was not long, however, before Russia made fresh demands upon China. After the signing, in September, I901, of the final Peace Protocol between China and the Powers, Russia appears to have felt herself once more free to treat independently with China concerning the settlement of the Manchurian question. ${ }^{38}$ A new Convention of Evacuation was prepared by M. Lessar, the new Russian Minister at Peking, early in October. The Russian proposals, which were disclosed to Mr. Conger, the American ambassador at Peking, by Prince Ching on December II, I90I, ${ }^{39}$ were substantially as follows: (I) Russia agreed to evacuate

"British Blue Book on China, No. 2 (1904), No. 37, p. 23. Cited by Asakawa, pp. $187-88$. The extract from the Russian Official Messenger of April 6, 1905, on pp. 17-23 of the Blue Book, cited above, is the best and most comprehensive statement of the Russian position which $I$ have seen.

* Russia had tried to treat the Manchurian question as one solely concerning the interests of China and Russia from the beginning, but the other Powers had refused so to regard it.

U. S. House Documents of the 57th Congress, 2nd session (Foreign Relations, 1903), pp. 271-72. 
Manchuria in three yẻars ${ }^{40}$ if "there are no repetitions of disorder, and the conduct of other nations does not hamper"; (2) that the Agreement of April, I899, with the RussoChinese Bank be adhered to; (3) that China undertake to protect the railways and Russian subjects in Manchuria, for which purpose mounted and foot soldiers (the numbers to be determined by agreement with Russia) might be stationed in lands other than those assigned to the Railway Company, provided that the use of artillery be excluded and that the troops of no other nationality be employed; (4) that subjects of no other nationality be permitted without the consent of Russia to build railways or bridges in Southern Manchuria.

In addition to the above proposed convention, the Russian Government insisted, in January, 1902, that China sign a separate agreement prepared by the Russo-Chinese Banik, which provided that China should herself undertake all industrial development in Manchuria. If, however, she needed financial aid, application should always be made, in the first instance, to the Russo-Chinese Bank; and only when the latter did not wish to give such aid might citizens of other countries be permitted to undertake such work. ${ }^{41}$ Great Britain, Japan, ${ }^{42}$ and the United States protested against these demands, Secretary Hay reminding the Russian and Chinese Governments, in February, 1902, of the repeated assurances made by Count Lamsdorff in favor of the principle of the open door in all parts of China. He said, among other things: "An agreement whereby China

"This term was afterwards reduced to two years.

${ }^{11} \mathrm{U}$. S. House Doc. of 57 th Congress, 2nd session, op. cit., pp. 273-74

${ }^{42}$ At least it is highly probable that Great Britain and Japan protested, though these protests do not appear in the published documents. See Asakawa, pp. 193-94. 
gives any corporation or company the exclusive right or privilege of opening mines, establishing railroads, or in any other way industrially developing Manchuria, can but be viewed with the greatest concern by the Government of the United States. It constitutes a monopoly, which is a distinct breach of the stipulations of the treaties concluded between China and foreign Powers, and thereby seriously affects the rights of American citizens." ${ }^{33}$

In reply to this note Count Lamsdorff reminded Secretary Hay of the fact that "negotiations carried on between two entirely independent states are not subject to be submitted to the approval of other Powers." He gave assurances that Russia had "no thought of attacking the principle of the 'open door' as that principle is understood by the Imperial Government of Russia," and that Russia had "no intention whatever to change the policy followed by her in that respect up to the present time. If the Russo-Chinese Bank should obtain concessions in China, the agreements of a private character relating to them would not differ from those heretofore concluded by so many other foreign corporations. . . . It is impossible to deny to an independent state the right to grant to others such concessions as it is free to dispose of, and I have every reason to believe that the demands of the Russo-Chinese Bank do not in the least exceed those that have been so often formulated by other foreign companies, and I feel that under the circumstances it would not be easy for the Imperial Government to deny to the Russian companies that support which is given by other Governments to companies and syndicates of their own nat onalities."*

${ }^{4}$ U. S. House Doc., 57th Congress, and session, Vol. I, pp. 275-76, and pp. 926-28.

"Ibid., p. 929. 
In spite of the firm tone of this note, Russia appears to have ceased to press China for her acceptance of these proposals, China (supported by the protests of Great Britain, Japan, and the United States) probably refusing to sign. It was now the turn of China to make counter-proposals, which were promptly accepted by Russia. This sudden change of attitude on the part of Russia was probably due to the conclusion of the Anglo-Japanese Agreement signed at London on January 30, 1902, and simultaneously announced in the British Parliament and at Tokio on February 12. This agreement, which was in the nature of a defensive alliance, was so important in strengthening the hands of Japan and Great Britain in dealing with Russia and China that it merits citation in full :

"The Governments of Great Britain and Japan, actuated solely by a desire to maintain the status quo and general peace in the extreme East, being moreover specially interested in maintaining the independence and territorial integrity of the Empire of China and the Empire of Korea, and in securing equal opportunities in those countries for the commerce and industry of all nations, hereby agree as follows :

"Article I. The High Contracting Parties having mutually recognized the independence of China and Korea, declare themselves to be entirely uninfluenced by any aggressive tendencies in either country. Having in view, however, their special interests, of which those of Great Britain relate principally to China, while Japan, in addition to the interests which she possesses in China, is interested in a peculiar degree, politically as well as commercially and industrially, in Korea, the High Contracting Parties recognize that it will be admissible for either of them to take such measures as may be indispensable in order to safeguard those interests if threatened by the aggressive action of any other Power, or by disturbances arising in China or Korea, and necessitating the intervention of either 
of the High Contracting Parties for the protection of the lives and property of its subjects.

"ART. II. If either Great Britain or Japan, in the defense of their respective interests as above described, should become involved in war with another Power, the other High Contracting Party will maintain a strict neutrality, and use its efforts to prevent other Powers from joining in hostilities against its ally.

"ART. III. If, in the above event, any other Power or Powers should join in hostilities against that ally, the other High Contracting Party will come to its assistance, and will conduct war in common, and will make peace in mutual agreement with it.

"ART. IV. The High Contracting Parties agree that neither of them will, without consulting the other, enter into separate agreements with another Power to the prejudice of the interests above described.

"ART. V. Whenever, in the opinion of either Great Britain or Japan, the above mentioned interests are in jeopardy, the two Governments will communicate with one another fully and frankly.

"ART. VI. The present Agreement shall come into effect immediately after the date of signature, and remain in force for five years after that date.

"In case neither of the High Contracting Parties should have notified twelve months before the expiration of the said five years the intention of terminating it, it shall remain binding until the expiration of one year from the day on which either of the High Contracting Parties shall have denounced it. But if, when the date fixed for its expiration arrives, either ally is actually engaged in war, the alliance shall, ipso facto, continue until peace is concluded." 45

A communication, bearing the same date, from Lord Lansdowne to Sir Claude MacDonald, the British Minister at Tokio, stated that "this agreement may be regarded as

- The British Parliamentary Papers, Treaty Series, No. 3, I902. Reprinted by Asakawa, pp. 202-204, and Beveridge, Appendix, pp. 482-83. 
the outcome of the events which have taken place during the past two years in the Far East," and that the Far Eastern policies of England and Japan were identical; both of them desiring that "the integrity and independence of the Chinese Empire should be preserved, that there be no disturbance of the territorial status quo either in China or the adjoining regions, that all nations should, within those regions, as well as within the limits of the Chinese Empire, be afforded equal opportunities for the development of their commerce and industry, and that peace should not only be' restored, but should, for the future, be maintained." 46

The publication of this treaty was followed on March I7, 1902, by the following declaration on the part of Russia and France:

"The allied Governments of Russia and France have received a copy of the Anglo-Japanese Agreement of the 3oth January, 1902, concluded with the object of maintaining the status quo and general peace in the Far East, and preserving the independence of China and Korea, which are to remain open to the commerce and industry of all nations, and have been fully satisfied to find therein affirmed the fundamental principles which they have themselves, on several occasions, declared to form the basis of their policy, and still remain so.

"The two Governments consider that the observance of these principles is at the same time a guarantee of their special interests in the Far East. Nevertheless, being obliged themselves also to take into consideration the case in which the aggressive action of third Powers, or the recurrence of disturbances in China, jeopardizing the integrity and free development of that

${ }^{4}$ The British Parliamentary Papers, Japan, No. I (1902). Reprinted by Asakawa, pp. 205-07.

In reply to questions in the British Parliament on February 12, I902, Lords Lansdowne and Cranborne both affirmed that the Anglo-Japanese Alliance applied to Manchuria as well as to any other province of the Chinese Empire. 
Power, might become a menace to their interests, the two allied Governments reserve to themselves the right to consult in that contingency as to the means to be adopted for securing those interests." 47

On April 8, I902, Russia accepted the counter-proposals of Prince Ching, referred to above, and concluded with China the famous Convention providing for the gradual evacuation of the whole of Manchuria within eighteen months from the date of signature. By the terms of this agreement, the Czar agreed to the "reëstablishment of the authority of the Chinese Government in that region (Manchuria), which remains an integral part of the Chinese Enpire," and restored "to the Chinese Government the right to exercise therein governmental and administrative authority, as it existed previous to the occupation by Russian troops" on the following conditions: (I) that the Chinese Government "observe strictly the stipulations of the contract concluded with the Russo-Chinese Bank on the 27th August, I896, and in virtue of paragraph 5 of the above mentioned

${ }^{17}$ Blue Book on China, No. 2 (1904), No. 50. Reprinted by Asakawa, pp. 209-10.

The St. Petersburg Official Messenger declared on March 20 that the Russian Government had received the announcement of the AngloJapanese Agreement "with the most perfect calm," inasmuch as Russia likewise desired "the preservation of the status quo and general peace in the Far East" and was also in favor of maintaining the integrity of China and Korea. It declared that "the intention expressed by Great Britain and Japan to attain those same objects, which have invariably been pursued by the Russian Government, can meet with nothing but sympathy in Russia, in spite of the comments in certain political spheres and in some of the foreign newspapers, which endeavored to present in quite a different light the impassive attitude of the Imperial Government toward a diplomatic act which, in its eye, does not change in any way the general situation of the political horizon." Cited by Asakawa, p. 2II. The italics are the author's. 
contract, ${ }^{48}$ assume the obligation to use all means to protect the railway and the persons in its employ, and bind itself to secure, within the boundaries of Manchuria, the safety of all Russian subjects in general and of all undertakings established by them."

"The Russian Government, in view of these obligations assumed by the Government of His Majesty, the Emperor of China, agrees on its side, provided that no disturbances arise and that the action of other Powers furnish no obstaclc,${ }^{40}$ to withdraw gradually all its forces from within the limits of Manchuria and in the following manner: (a) within six months from the signature of the agreement to clear the southwestern portion of the province of Mukden up to the Liao River of Russian troops, and to hand over the railways to China; (b) within the following six months to clear the remainder of the province of Mukden and the province of Kirin of Imperial troops; (c) within the six months following to withdraw the remaining Imperial Russian troops from the province of Hei-lung-chang. (Article II.)

"In view of the necessity of preventing in the future any recurrence of the disorders of last year, in which Chinese troops stationed on the Manchurian frontier also took part, the Imperial Russian and Chinese Governments shall undertake to instruct the Russian military authorities and the Tsiang-Tsungs (local Governors), mutually to come to an agreement respecting the members and the disposition of the Chinese forces until the Russian forces shall have been withdrawn. At the same time the Chinese Government

48 This paragraph imposed upon China the duty of protecting the Manchurian Railway and its employees.

${ }^{40}$ The italics are the author's. 
binds itself to organize no other forces over and above those decided upon by the Russian military authorities and the Tsiang-Tsungs as sufficient to suppress brigandage and pacify the country. After the complete evacuation of Manchuria by Russian troops, the Chinese Government shall have the right to increase or diminish the number of its troops in Manchuria, but of this it must duly notify the Russian Government. . . . "For police service and maintenance of internal order in the districts outside those parts alotted to the Eastern Chinese Railway Company, a police guard, under the local Governors (Tsiang-Tsungs), consisting of cavalry and infantry, shall be organized exclusively of subjects of His Majesty the Emperor of China." (Article III.)

In view of the restoration by the Russian Government to its owners of the Shan-hai-kwan-Niu-chwang-Siumin-ting Railway, which, since the end of September, I900, had been occupied and guarded by Russian troops, the Chinese Government bound itself: (a) not to invite other Powers to participate in the protection, construction, or working of this railway, "nor to allow other Powers to occupy the territory evacuated by the Russians"; (b) to conduct the completion and working of said line in strict accordance with the Agreement between Russia and England of April 16, I899, and to observe the contract respecting the loan for its construction; (c) "should, in the course of time, extensions of the line in Southern Manchuria, or constructions of branch lines in connection with it, or the erection of a bridge in Niu-chwang, or the moving of the terminus there, be undertaken, these questions shall first form the subject of mutual discussion between the Russian and Chinese Governments"; (d) the Chinese Government recog- 
nized its liability for the expenses incurred by the Russian Government in repairing and working the said line during the period of its occupation. (Article IV.) ${ }^{50}$

At the same time, M. Lessar handed a note to the Chinese Plenipotentiaries which declared, in the name of the Russian Government, that the surrender of the civil government of Niu-chwang into the hands of the Chinese would take place only after the withdrawal from that port of the foreign forces and landing parties and the restoration to the Chinese of the town of Tien-tsin, then under international administration. He also declared that "if the Chinese Government, in spite of their positive assurances, should, on any pretext, violate the above conditions, the Imperial Government (of Russia) would no longer consider itself bound by the provisions of the Manchurian Agreement, nor by its declarations on this subject, and would have to take all responsibility for all consequences which might ensue." 51

It will be seen that even the comparatively mild conditions imposed upon China (at her own suggestion, it is true) by this Convention were very difficult, if not impossible, to fulfill. China was to be held responsible for the security of all Russians and their enterprises in Manchuria, but Russia was practically to determine the number of troops which would be required for this purpose. The inevitable failure of China to suppress internal disorder or prevent the incursions and depredations of the Chunchuses or mounted bandits of Manchuria and Mongolia, might at any time be made

${ }^{80}$ For a French text of this convention, see Blue Book on China, No. 2 (1904), No. 54. Reprinted by Asakawa, pp. 215-218. For an English version, see Blue Book, op. cit., No. 5I, and Asakawa, pp. 220-24.

${ }^{31}$ China, No. 2 (1904), p. 38. Cited by Asakawa, pp. 224-25. The italics are the author's. 
a pretext for the refusal of Russia to withdraw her troops from these provinces. Besides, it would always be open to Russia to allege that the action of some other Power or Powers in China constituted a sufficient bar to such withdrawal. The right of Russia to continue to police the Manchurian railway by means of the so-called "railway" or "frontier guards" seems to have been tacitly permitted.

Inasmuch as the Convention of Evacuation made no provision for the exclusive control of mining and railway enterprises in Manchuria by Russian subjects, no objection was raised by any of the Powers; for "they probably preferred the imperfect obligation the Convention imposed upon the contracting parties, to an indefinite prolongation of the dangerous conditions which had prevailed. What remained for them and for China was to watch the conduct of Russia in Manchuria and test her veracity according to their own interpretations of the Agreement." ${ }_{2}$

By October 8, 1902, at the end of the first six months, Russia had handed over the Chinese Railway to the Chinese Government and withdrawn her troops from the southwestern portion of the Sheng-king or Mukden province as far as the Liao River; but a considerable number of these troops appear to have been simply transferred to other parts of Manchuria, where they were transformed into railway guards. $^{53}$ The evacuation of Niu-chwang was delayed, however, for trivial reasons, in spite of the fact that the conditions named by M. Lessar in his note of April, I9or, had been met; and this important treaty-port remained in the

${ }^{32}$ Asakawa, p. 233.

${ }^{s}$ See especially Dr. Morrison's articles in the London Times for January 3 and 14, I903. See also Blue Book on China, No. 2 (1904), Nos. 56, 58, $60 \mathrm{ff}$., and U. S. House Doc., 57th Congress, and session (For. Rel.), pp. $28 \mathrm{r}$ ff. 
possession of the Russians until they were driven out by the Japanese during the early months of the war.

By April 8, 1903, the date set for the evacuation of the remainder of the province of Mukden and of the province of Kirin, it had become evident from the disposition of the Russian forces in Manchuria that not even a nominal withdrawal was intended. ${ }^{54}$ It was even reported early in May, I903, that a number of Russian soldiers in civilian dress had advanced across the Yalu River into Korea and were cutting timber at Yong-am-po. In the meantime (early in April) Russia had made seven new demands upon China, upon the acceptance of which the further evacuation of Manchuria appears to have been practically conditional. These demands, which were rejected by China, appear to have been substantially as follows: $:^{55}$ (I) that "no portion of territory restored to China by Russia, especially at Niuchwang and in the valley of the Liao-ho, shall be leased or sold to any other Power under any circumstances;" (2) that the status quo be maintained in Mongolia; (3) that "China shall engage herself not to open, of her own accord, new

${ }^{34}$ U. S. House Doc. of 58 th Congress, and session, Vol. I (For. Rel.), I903-4, p. 53. It appears that some pretense of evacuation was made in the Sheng-king province where some Russian troops were withdrawn to the railway line. Asakawa, p. 239. At Mukden there was a sham evacuation.

${ }^{*}$ For the most authentic text of these demands obtainable by England, see Blue Book on China, op. cit., No. 94. For the original Russian note sent by M. de Plancon to Prince Ching, see U. S. House Doc. of 58th Congress, 2nd session (For. Rel.), pp. 56-58. See also Asakawa, pp. 242-44. In his interview of April 28, 1903, with Mr. McCormick, the American ambassador at St. Petersburg, Count Lamsdorff denied in the most positive manner that such demands were made by the Russian Government; but the denial of Count Lamsdorff was partly offset by the admissions made by Count Cassini in his remarkable interview which appeared in the New York Tribune for May I, 1903. Cited by Asakawa, p. 249. 
ports or towns in Manchuria, without giving previous notice to the Russian Government, nor shall she permit foreign consuls to reside in these towns or ports;" (4) that "the authority of foreigners, who may be engaged by China for the administration of any affairs whatever, shall not be permitted to extend over any affairs in the Northern Provinces (including Chili) where Russia has the predominant interests. In case China desires to engage foreigners for the administration of affairs in the Northen Provinces, special offices shall be established for the control of Russians: for instance, no authority over the mining affairs of Mongolia and Manchuria shall be given to foreigners who may be engaged by China for the administration of mining affairs; such authority shall be left entirely in the hands of Russian experts"; (6) that the custom receipts of Niu-chwang shall continue to be deposited with the Russo-Chinese Bank after the restoration of that port to the Chinese local authorities; (7) that the rights acquired in Manchuria by Russian subjects and foreign corporations during the Russian occupation shall remain unaffected after the evacuation. ${ }^{56}$

It will be seen that these demands included stringent measures for closing Manchuria against the economic enterprises of all foreigners except Russians, and that they practically forbade the opening of new treaty-ports in Manchuria without the consent of Russia. They were, therefore, in direct opposition to the principle of the open door, and it is not in the least surprising that their publication was followed

* This article also contained provision for the establishment of a quarantine office and a permanent Sanitary Board at Niu-chwang, after its restoration to China. Article 5 (omitted in the text) provided for the retention by Russia of the control of the telegraph line between Port Arthur and Mukden. 
by firm protests at Peking on the part of Japan, Great Britain, and the United States.

October 8, 1903, the date set for the final evacuation of the province of Hei-lung-chang, arrived and the Russians were still in possession of practically the whole of Manchuria with the exception of the region west of the Liao River. They still retained control of Niu-chwang, and by the end of October ${ }^{57}$ they had actually reoccupied Mukden. ${ }^{58}$ Although there had been no serious disturbances in Manchuria, and although Russia did not even allege that any of the Powers had placed obstacles in the way of such withdrawal, there was no further attempt to carry out the provisions of the Convention of Evacuation, and it became increasingly evident that Russia intended to remain in Manchuria and absorb that vast and productive region politically as well as exploit it economically.

The aggressive and exclusive policy of Russia in Manchuria-dangerous as this policy was to the interests of Japan and other Powers in China-might perhaps have been tolerated by Japan had it not been for clear indications of an intention on the part of Russia to make similar encroachments in Korea, long since regarded by the Japanese as

${ }^{\text {s7 }}$ On September 6, 1903, six fresh demands were made by Russia on China. See Blue Book, op. cit., Nos. $147 \mathrm{ff}$., especially No. 156. The most important of these demands appear to have been that "China shall undertake not to alienate any part of Manchuria to another Power, nor to grant land for the purpose of foreign settlements," and that "no greater duties be imposed on goods brought into Manchuria by rail than those now imposed on goods transported by road or river." These demands were rejected by the Chinese Government at the instigation of the British and Japanese Ministers at Peking.

s This re-occupation of Mukden by Russian troops, although unimportant in itself (Mukden having never been really evacuated), is said to have greatly excited public feeling in Japan against Russia. 
within the sphere of their special or predominant interests. The peninsula of Korea, although geographically and historically connected with the Manchurian Hinterland, faces Japan, as a Japanese statesman has graphically said, "like an arrow with the point aimed at her heart."

Lying at the very door of Japan and separated from her only by the Korean Straits, ${ }^{59}$ Korea has at intervals been an object of interest or ambition on the part of the Japanese ever since the invasion and temporary subjugation of southeastern Korea (Shinra) by the Empress Jingu at the beginning of the third century, A. D. (2OI-203?). From that day to the year 1876 , when Japan signed a treaty recognizing the independence of Korea-an acknowledgment which led to the great Satsuma rebellion against the Japanese Government in 1877 - Korea $^{60}$ was regarded by the Japanese as a tributary or vassal state. A similar claim of suzerainty was made by the Chinese and acknowledged by the Koreans, ${ }^{61}$ so that, during a considerable part of this period at least, we have the curious spectacle of a people paying

${ }^{60}$ The Japanese islands of Tsushima, from which the Japanese mainland is visible, are only fifty miles distant from the magnificent harbor of Masampo on the southern coast of Korea.

${ }^{80}$ This is at least true of Shinra or southeastern Korea. The Koreans did not form a united state before 934 A. D.

"The Chinese claim to Korea is much older than the Japanese. It goes back to the year II 22 B. C., but the first real conquest of "Korai" (northern Korea) by China dates from the middle of the seventh century, A. D. (664). The claims of Japan have, therefore, a better historical basis than those of China. Besides, the attitude of China toward the Koreans has always been that of a patron rather than a master. As a rule, China has claimed neither the right of regulating their internal affairs nor of meddling in matters of foreign policy. She has at times even gone to the extent of disclaiming responsibility for Korea's misdeeds and of disavowing any active political interest in the peninsula. 
tribute to two suzerains and acknowledging the overlordship of both.

The relations between Japan and Korea appear to have been particularly close and active from the third to the thirteenth centuries, A. D. There were frequent tribute missions, and a steady stream of commerce and immigration flowed from the peninsula into the archipelago. Japan profited immeasurably by this intercourse, so much so that, as Griffis" ${ }^{62}$ says: "It must never be forgotten that Korea was not only the bridge on which civilization crossed from China to the archipelago, but was most probably the pathway of migration by which the rulers of the new race now inhabiting Nippon reached it from the ancestral seats around the Sungari and the Ever-White Mountains. True, it is not absolutely certain whether the homeland of the Mikado's ancestors lay southward in the sea, or westward among the mountains, but that the mass of the Korean and Japanese people are more closely allied in blood than either are the Chinese, Manchus, or Malays seems to be proved, not only by language and physical traits, but by the whole course of the history of both nations, and by the testimony of Chinese records. Both Koreans and Japanese have inherited the peculiar institutions of their Fuyu ancestors-that race which alone of all the peoples sprung from Manchuria, migrated toward the rising, instead of the setting sun."

In the early part of the thirteenth century China and Korea were conquered by the Mongols under Genghis Khan, and it was from Korea that his grandson Khublai Khan dispatched his ill-fated expedition for the conquest of Japan in 1281. The Mongol conquest of Korea seems to mark the definite ascendency of Chinese influence in the peninsula

${ }^{92}$ Corea, The Hermit Nation (7th ed.), pp. 6r-62. 
-an influence which appears to have been increased rather than diminished by the fall of the Mongols and the establishment of the native Ming dynasty on the throne of China in the middle of the fourteenth century ( $134 \mathrm{I}-\mathrm{r} 368$ ).

The Japanese had been neglecting foreign affairs for several centuries, and it was partly in order to recover lost ground in Korea that Hideyoshi ${ }^{63}$ invaded the peninsula in I592. The six years of slaughter and devastation in Korea which followed left Japan in possession of the islands of Tsushima in the Korean Strait and gave her a bare foothold on the mainland at Fusan (a position which Japan retained until 1876 ), but it left behind it a legacy of hatred for Japan in Korea- a hatred from which the Japanese suffer to this day.

After the invasion of Hideyoshi, which had been resisted with the aid of China, the ascendency of Chinese interests and influence in Korea became more pronounced than before, although Japan still retained sufficient influence to insist upon the annual tribute missions-embassies which were really sent at the expense of the Japanese-during the seventeenth and eighteenth centuries. During this period the suzerainty of Japan was merely nominal, while that of China was more or less real, ${ }^{64}$ and the tribute missions to Japan ceased altogether after the first decade of the nineteenth century.

${ }^{3}$ This would-be conqueror also aimed at the conquest of China, to which that of Korea was to be merely a prelude. For good accounts of the invasion of Hideyoshi, see Griffis, ch. I3, and Hishida, Japan as a Great Power, in the Columbia University Studies in History, etc., Vol. XXIV, pp. 302-310.

os In the seventeenth century Korea succumbed to the Manchus like the rest of China. The bonds of vassalage between China and Korea seem, indeed, to have been drawn tighter by the Manchus than they were before. 
The beginning of the modern phase of the Korean question dates from the year I868. In that year the Japanese, having abolished the Shogunate and feudalism, and having restored the power of the Mikado as a result of revolution and the opening of Japan to the influence of Western civilization, determined to reassert their ancient claims of suzerainty over Korea. Accordingly, the Korean Government was invited to return to its former state of vassalage to Japan. This invitation was met with an insolent refusal at Seoul, and the war-party in Japan clamored for war; but the Japanese Government resisted this clamor and tried to reëstablish its influence in the peninsula by peaceful means. Little progress was made, however, for the Koreans had not forgotten the Japanese invasion of the sixteenth century; besides, they resented the Japanese adoption of western manners and customs. Fearful of arousing the hostility of China and Russia, and, having learned by inquiry at Peking that the Chinese Government renounced the right of interference with the external or internal affairs of Korea, Japan agreed in $1876^{65}$ to recognize the independence and equality of Korea as a sovereign state. In addition to Fusan, which was recognized as a Japanese settlement and open port of commerce between Japan and Korea, Japan also obtained a promise that two new ports should be opened to Japanese trade-a promise which was not fulfilled, however, before I 880 .

In the meantime, other Powers had also become interested in this attempt to open the doors of the "Hermit Nation" to trade-a policy which was at first encouraged by the great Chinese statesman $\mathrm{Li}$-Hung Chang with a view of strength-

${ }^{\star 5}$ For the treaty of 1876 , see De Martens, Nouveau recueil, and series, t. III, p. 5 II. 
ening the influence and position of China in Korea. In spite of the violent opposition at times of the "Exclusionists" or "Port Closers", the "Civilization" or "Progressionist" party triumphed in Korea, and in I882 treaties of friendship and commerce were concluded with England and the United States. These were followed by similar treaties with Germany in 1883 , with Russia and Italy in 1884 , with France in I886-7, and with Austria-Hungary in 1892 .

This "open door" policy was, as above stated, violently and bitterly opposed by the "Exclusionist" faction in Korea, who incited an insurrection, in I882, directed mainly against the Japanese at Seoul, which resulted in the intervention of China and Japan and the stationing of Chinese and Japanese troops in Korea. In December, 1884 , as a result of another insurrection, which had been incited by members of the pro-Japanese or "Civilization" faction, these troops came into conflict, and China and Japan suddenly found themselves on the brink of war. But at the eleventh hour war was averted by the conclusion of the Convention of Tientsin, negotiated by Count Ito and $\mathrm{Li}-\mathrm{Hung}$ Chang, in 1885 , in which both states agreed to withdraw their forces and not to dispatch troops to Korea in the future without previous notice to the other. ${ }^{68}$ This treaty was a great diplomatic

For good accounts of these events, see especially Curzon, Problems of the Far East, ch. 7; Norman, Peoples and Politics of the Far East, ch. 23; an article on "The Question of Korea" in The Fortnightly Review for 1903, Vol. 80, pp. 846 ff., by Alfred Stead; and the last (7th) edition of Griffis, Corea, ch. 50 . See also Hishida, op cit., pp. $165 \mathrm{ff}$.

In 1885 Count Ito drew up the following agreement for the peaceable settlement of the pending dispute between China and Japan:

"The pretension of Japan over Korea is economical, $i$. $e$., she does not claim any legal authority over Korea, but from her geographical position and the necessity of providing for her constantly increasing population, she is intent on utilizing Korea as the best source from 
triumph for Japan, for it implied the recognition by China of the fact that Japan stood upon a footing of equality with herself in Korea.

The years from i 885 to 1894 were comparatively quiet and peaceful, and Japan appears to have been fairly success$\mathrm{ful}$ in her attempts to obtain a fiscal and commercial ascendency in Korea in spite of Chinese intrigues and Korean conservatism.

It was during these years that Russia appears for the first time as an important factor in Korean affairs. In 1884 "rumours, not without solid foundation, were circulated of a secret agreement between Russia and Korea, negotiated by the German adviser of the King, by which Russia was to reorganize the Korean army and to support the Korean claims to Tsushima, while Korea in return was to cede Port Hamilton; and it was something more than rumour of the latter intention that induced the British Government to anticipate an impending Muscovite seizure by hoisting the British flag upon those islands" "67 (in April, I885). In I886 a further plot for placing Korea under Russian protection was detected by the Chinese Resident at Seoul. In the same year, the Chinese Government having obtained a promise from Russia that "if the British would evacuate Port which the defect of the home produce of rice is to be supplied as well as the nearest field in which the future sons of Japan may find employment. For this purpose Japan would have Korea always independent, and under no foreign influence, but within the last years China has been sending military and political agents to Korea, and interfering with Korean international affairs, as if she intended to make real her pretensions over Korea, which have long since become purely historical. This state of things must be rectified, for Japan would never consent to Korea's becoming in reality a part of the Chinese Empire."

Cited by Alfred Stead in Fortnightly Review (1903), Vol. 80, pp. $852-53$.

${ }^{\text {ez }}$ Curzon, op cit. p. 2 10. The date is supplied by Norman, p. 369. 
Hamilton, the Russian Government would not occupy Korcan territory under any circumstances whatever," that island was evacuated on February $27,1887 .{ }^{68}$ But in 1888 Russia concluded a commercial convention with Korea by which she obtained valuable concessions in the way of lower customs duties on goods imported overland from Russia into Korea (i.e., lower than on sea-borne imports), and the right of having "agents" in northern Korea. An overland telegraphic connection between Russia and Korea was also obtained a few years later (in I893).

In 1894 , in consequence of a third insurrection, Japanese and Chinese troops once more found themselves face to face in Korea. Japan, incensed by the murder of her protégé Kim-ok-Kim at Shanghai, was determined to solve the Korean question by the introduction of certain reforms, as well as by the suppression of the rebellion. China, on the other hand, opposed these reforms and, calmly ignoring the Tientsin Convention, reasserted her ancient claims of suzerainty. Among the results of the Chino-Japanese War of I 894-95 was the "definitive" recognition by China of "the full and complete independence and autonomy of Korea." ${ }^{\prime 9}$

The impolitic attempts at hasty and radical reform in Korea, which followed the outbreak of the Chino-Japanese War, were resisted by the Court party at Seoul, headed by the Queen and the Min family, to which she belonged. ${ }^{70}$ Early in October, I895, the Queen planned a coup d'état with a view to disbanding the soldiers who had been trained by Japanese officers, and of replacing the pro-Japanese par-

For citation from the British Blue Book on China, No. I (I887), p. 38 , see Norman, p. 370.

" Art. I of the Treaty of Shimonoseki.

${ }^{70}$ This faction was doubtless aided by the intrigues of M. Waeber, the Russian representative at Seoul. 
tisans of reform in the Korean Cabinet by her friends. The result was a counter-plot (in which the King's father, the veteran conspirator Tai-wen-Kun, was a prime mover) to seize the King and Queen with the aim of obtaining complete control of the Korean Government in the interest of the pro-Japanese and reform party. In carrying out this plot (in which the Japanese Minister Miura seems to have been an accomplice), the Queen was murdered by Japanese and Korean ruffians. ${ }^{71}$

This disgusting crime, although it assured the power of the reform cabinet for the time being, reacted upon its perpetrators, and was followed, four months later, by another equally revolting, by means of which Russia obtained control of the Government of Korea. "In January, I896, there took place a slight uprising in Northern Korea, at the instigation, it was said, of pro-Russian leaders. When the major portion of the army had been sent out of the capital to suppress the rebellion, 127 Russian marines with a cannon suddenly landed at Chemulpo on February ro, and immediately entered Seoul."72 The next day, the King, accompanied by the Crown Prince and some court ladies, fled in disguise to the Russian Legation, where he remained until February 20, 1897. As a result of a royal edict, which declared the Cabinet Ministers guilty of treason, the Prime Minister and two other ministers were murdered on the streets of Seoul in broad daylight, while several others fled to Japan.

A brief period of Russian ascendency now followed, dur-

${ }^{11}$ Asakawa (p. 26I) says it is "probable that the murder of the Queen was premeditated and that Minister Miura had been prevailed upon to connive at the guilt of the murderers." For further evidence, see M. Rey in Revue Générale de Droit International Public, note on p. 308.

${ }^{72}$ Asakawa, p. 262. 
ing which Japan saw herself deposed from the position in Korea to which her victories entitled her, by a nation which appeared to be both an upstart and a usurper on the Sea of Japan. Among other things, the Russians obtained a valuable timber concession in the Yalu valley on the northern frontier, and a mining concession along the Tumên River. The Korean troops trained by Japanese officers were abolished and the Japanese soldiers stationed in Korea reduced in number.

In the summer of I896 Japan formally departed from her policy of the past two decades of upholding the independence and integrity of Korea by her own efforts, and sought the coöperation of Russia toward the same end. On May I4 the Russian and Japanese Ministers at Seoul concluded a Memorandum which fixed the number and disposition of Japanese and Russian troops in Korea. ${ }^{73}$ On June 9, I 896, the Yamagata-Lobanoff Protocol was signed at St. Petersburg. It was thereby agreed: (I) That the Japanese and Russian Governments should unite in advising the Korean Government to "suppress all unnecessary expenses and to establish an equilibrium between expenditure and revenue. If, as a result of reforms which should be considered indispensable, it should become necessary to have recourse to foreign debts, the two Governments should, of a common accord, render their support to Korea." (2) "The Japanese and Russian Governments should try to abandon to

The Japanese were to be permitted to have 200 gendarmes for the protection of their telegraph line between Fusan and Seoul. Russia and Japan were to be allowed to keep an equal and specified number of troops at Seoul, Fusan, and Gensan. These troops were to be withdrawn as soon as internal tranquillity was assured, but this contingency apparently never arose. For the terms of this Memorandum, see Asakawa, pp. $265-66$. 
Korea, in so far as the financial and economic situation of that country should permit, the creation and maintenance of an armed force and of a police organized of native subjects, in proportion sufficient to maintain internal order, without foreign aid." (3) Russia was to be permitted to establish a telegraph line from Seoul to her frontier, the Japanese Government being allowed to administer those lines already in its possession. (4) "In case the principles above expounded require a more precise and more detailed definition, or if in the future other points should arise about which it should be necessary to consult, the representatives of the two Governments should be instructed to discuss them amicably." It will thus be seen that Asakawa does not overstate the case when he says : ${ }^{75}$ "Despite the millenniums of her historic relations with Korea, and the actual preponderance of her interests therein, and after her successful liberation of the kingdom from Chinese suzerainty by a costly war, Japan now admitted into the peninsular politics on an equal footing with herself a Power which owed its bright success to a mere diplomacy of less than two years' standing, and whose policy seemed to be guided by principles entirely at variance with the independence and strength of Korea."

The Protocol of June, I896, was no sooner signed than Russia began to violate its terms. In the same month Russia decided to try to gain control of the Korean army by giving it Russian military instruction and discipline. This plan was partly carried out in the following year. In the same year ( 1897 ) she attempted to obtain control of Korean finances by requesting that the disposal of all taxes and customs be placed in the hands of M. Kir Alexieff. Mr. Brown,

${ }^{74}$ For the text, see Asakawa, p. 264.

${ }^{75}$ Ibid., p. 267. 
a British subject, was accordingly dismissed from the position of Financial Adviser and General Director of Customs in Korea on October 26, 1897 , in spite of the protest of the British Consul, and the Russo-Korean Bank was organized to transact the financial and commercial affairs of the peninsula; but Mr. Brown was soon restored to his former office in consequence of a visit to Chemulpo of seven British menof-war on December 27, 1897.

The suspicions and opposition of the Koreans were aroused by these measures, as well as by the overbearing conduct of M. Speyer, who had replaced M. Waeber as Russia's representative at Seoul; and a strong reaction or revulsion of feeling against Russia set in which changed the attitude of the Korean Government and people toward Japan. For this and other reasons (the chief of which was doubtless her recent lease of Port Arthur and Talien-wan) Russia found it advisable to try to conciliate Japan. Accordingly, there was concluded between these two nations the Nishi-Rosen Protocol of April 25, 1898. This agreement is sufficiently important to be quoted in full :

"Article I. The Imperial Governments of Japan and Russia definitely recognize the sovereignty and entire independence of Korea, and mutually engage to abstain from all direct interference in the internal affairs of that country.

"ART. II. Desiring to remove every possible cause of misunderstanding in the future, the Imperial Governments of Japan and Russia mutually engage, in case Korea should have recourse to the counsel and assistance of either Japan or Russia, not to take any measure regarding the nomination of military instructors and financial advisers, without having previously arrived at a mutual accord on the subject.

"ART. III. In view of the great development of commercial and industrial enterprise of Japan in Korea, as also the con- 
siderable number of Japanese subjects residing in that country, the Russian Imperial Government shall not impede the development of the commercial and industrial relation between Japan and Korea." ${ }^{\prime 6}$

It will be seen that this Protocol was much more favorable to Japan than the two agreements of 1896 . It not only contained an explicit recognition of the "sovereignty and entire independence" of Korea, but it restored Japan to a footing of political equality with Russia in the peninsula, and, in addition, Japan obtained from Russia a formal recognition of her special economic interests in that country.

In spite of this agreement, the rivalry between Japan and Russia in Korea continued during the next five years (I899I904), under the leadership of Mr. Hayashi and M. Pavloff, the representatives at Seoul of Japan and Russia respectively. Russia appears in most cases to have been the aggressor, repeatedly violating the Protocols of 1896 and 1898 , while Japan seems to have confined herself to the quiet development of her commercial and industrial interests in the peninsula. Nearly every move made by the bold and enterprising Pavloff was checkmated or duplicated by the cautious but persistent Hayashi, and, on the whole, it may be said that Japan regained and maintained her former commercial and financial ascendency in Korea. ${ }^{77}$

${ }^{76}$ For the French text of this Protocol, see Treaties and Conventions between Japan and other P'owers, p. 394. See also Alfred Stead in Fortnightly Review, Vol. 8o, pp. 856-57. For the English translation, see Asakawa, p. 27I. It should be noted that this Protocol together with that of 1896 became the basis of Japan's direct negotiations with Russia regarding Korea which preceded the Russo-Japanese War.

${ }^{7} E$. g., Japan obtained a concession from the Korean Government giving her the right of priority of construction of railways between Seoul and Fusan. She also obtained control of the finances of the country by the establishment of banks and the control of the currency. 
The first efforts of Russia (1899-190I) were directed toward acquiring certain leases at Masampo on the southern coast of Korea, with a view of transforming this valuable harbor into a base for the use of the Russian navy; but M. Pavloff found himself outwitted and checkmated at every turn by the Japanese, who had managed to secure possession of every valuable and important site within the three-mile limit open to foreign purchase. But Russia succeeded in obtaining some leases of little practical value, and secured from the Korean Government a "pledge" not to alienate any part of the Kojedo Island, near Masampo, Russia herself agreeing not to seek such alienation on her part. ${ }^{78}$

There was also an unsuccessful attempt during this period to place the Korean Government under financial obligations to Russia by means of a French loan, and Russian agents or emissaries caused considerable irritation in Japan by vainly attempting to obstruct the circulation of the bank notes issued by the Korean branch of the First Bank of Japan. In March, I899, M. Pavloff succeeded in leasing, for the use of a Russian subject, three whaling stations on the northeastern coast of Korea ;" but "this concession was offset by one secured by a Japanese citizen on February 14, 1900, which conferred upon him the right of whaling for three years, subject to renewal, along the Korean coast.", 80

Japanese trade with and emigration to Korea have also greatly increased since $I 895$.

${ }^{73}$ Asakawa, p. 276. Cf. Hamilton, Korea, pp. 198-99. Russia afterwards attempted to secure a naval base at Nam-pu on the Ching-kaiwan about 20 miles south of Masampo, but failed owing to the strenuous protest of Japan. See Hamilton, op. cit., p. 200.

${ }^{70}$ For this contract see U. S. House Doc.. 56th Congress, Ist session, pp. 484-88. For some interesting comments on these leases, see London Times for June 2, 1899 .

Asakawa, p. 283. 
Another bone of contention between Japan, on the one side, and Russia and France, on the other, lay in the question of the construction of the Seoul-Wiju Railway. In I 894 Korea had granted to Japan priority of rights in the construction of railways between Seoul and Fusan. In 1898 Japan obtained control of the short railway between Seoul and Chemulpo-an American concession-and in the same year Japan entered into a definite contract with the Korean Government for the construction of the Fusan-Seoul line. ${ }^{81}$ Prior to this (in 1896 ) a French company had been granted a concession to build a railway from Seoul to Wiju on the Yalu, but this company tried to sell its concession, first to Russia and afterward to Japan. In I900 the Korean Government announced that the line would be built with Korean capital, but this project had to be abandoned. In 1903 Russia made several attempts to obtain the concession, but the Korean Government declined to entertain such a proposition.

But, aside from her attempts to obtain control of the harbor of Masampo, Russia's conduct on the northern frontier of Korea along the Tumên and Yalu rivers was the greatest source of anxiety to Japan. In I896 Russia had obtained valuable mining concessions in two districts near the port of Kiong-hung at the mouth of the Tumên River, and later sought to extend her influence in that region. More important and dangerous, however, to the interests of Japan were the attempts of Russia to obtain an actual foothold on Korean territory at Yong-am-po on the Korean side of the Yalu River. As far back as 1896 , when the Korean king

${ }^{81}$ This line was in process of being built at the outbreak of the RussoJapanese War. It has since been completed and the line extended to Wiju. 
was a guest at the Russian legation, a Russian merchant had obtained timber concessions on the Uining Island in the Sea of Japan and on the Tumên and Yalu rivers. The concession along the Yalu was to be forfeited unless work was begun within five years in the other two regions. This condition $^{82}$ does not appear to have been complied with when the Korean Government was suddenly notified on April I3, I903, that the Russian timber syndicate would at once begin the work of cutting timber on the Yalu. Early in May, sixty Russian soldiers in civilian dress, later increased by several hundred more, were reported to have occupied Yongam-po, a point rather remote from the places where actual cutting was in progress. "At the same time, there was taking place a mysterious mobilization of troops from Liaoyang and Port Arthur towards Feng-hwang-Cheng and Antung on the other side of the Yalu." ${ }^{83}$ Early in June four Russian warships paid a week's visit to Chemulpo. In August, M. Pavloff appears to have been on the point of obtaining an extension of the Yong-am-po lease from the Korean Government, but this was prevented by the receipt of an ultimatum from the Japanese Minister. In his dispatch of August 25, Mr. Hayashi threatened that if the Korean Government were to sign such a lease, Japan would regard diplomatic relations between the two countries as suspended, and would consider herself free to act in her own interests. ${ }^{84}$

In the meantime, a state of anarchy had prevailed on the

"22 Asakawa, p. 290. Cf. Hamilton, p. 201.

${ }^{83}$ Asakawa, p. 292 . For a more detailed account of these movements, see Blue Book on China, No. 2 (1904), Nos. I15, 116, 128, 129, 131, and I34.

See Hamilton, Korea, pp. 201-206. 
northern frontier of Korea, and Russia had increased her forces at Antung. In the face of these ominous events in Korea-doubly ominous in view of the suspension of the Russian evacuation of Manchuria-Japan decided to institute direct negotiations with Russia with a view of arriving, if possible, at a definite understanding or solution of the Korean and Manchurian questions which would be satisfactory to both nations.

On July 28, I903, Mr. Kurino, the Japanese Minister at St. Petersburg, was informed by Baron Komura, the Japanese Foreign Minister, that the recent conduct of Russia at Peking (in proposing new demands), in Manchuria (by tightening her hold upon it), and in Korea (by her increased activity on the Korean frontier) had caused grave concern to the Imperial Government of Japan. "The unconditional and permanent occupation of Manchuria by Russia would," he said, "create a state of things prejudicial to the security and interests of Japan. The principle of equal opportunity would thereby be annulled, and the territorial integrity of China impaired. There is, however, a still more serious consideration for the Japanese Government, that is to say, if Russia was established on the flank of Korea it would be a constant menace to the separate existence of that Empire, or at least would make Russia the dominant Power in Korea. Korea is an important outpost in Japan's line of defense, and Japan consequently considers her independence absolutely essential to her own repose and safety. Moreover, the political as well as commercial and industrial interests and influence which Japan possesses in Korea are paramount over those of other Powers. These interests and influence Japan, having regard to her 
own security, can not consent to surrender to, or share with, another Power."

In view of these interests, so vital to Japan, Mr. Kurino was instructed to present the following note verbale to Count Lamsdorff, the Russian Minister of Foreign Affairs :

"The Japanese Government desire to remove from the relations of the two Empires every cause of future misunderstanding, and believe that the Russians share the same desire. The Japanese Government would therefore be glad to enter with the Imperial Russian Government upon an examination of the condition of affairs in the regions of the extreme East, where their interests meet, with a view of defining their respective special interests in those regions.

"If this suggestion fortunately meets with the approval, in principle, of the Russian Government, the Japanese Government will be prepared to present to the Russian Government their views as to the nature and scope of the proposed understanding." 86

The assent of Count Lamsdorff and the Czar having been obtained on August 12, the following articles were prepared by the Japanese Government as the basis of an understanding between Japan and Russia :

"I. A mutual engagement to respect the independence and territorial integrity of the Chinese and Korean Empires, and to maintain the principle of equal opportunity for the commerce and industry of all nations in those countries.

"2. A reciprocal recognition of Japan's preponderating in-

${ }^{*}$ Correspondence between Japan and Russia (1903-1904), published by the Japanese Government. Baron Komura to Mr. Kurino, Dispatch No. I. Translation by Asakawa, pp. 297-298. On the whole Asakawa's translation of these dispatches is to be preferred to that of the official publication.

${ }^{*}$ Asakawa, pp. 297-98. 
terests in Korea and Russia's special interests in railway enterprises in Manchuria, and of the right of Japan to take in Korea, and of Russia to take in Manchuria, such measures as may be necessary for the protection of their respective interests as above defined, subject, however, to Article I of this Agreement.

"3. A reciprocal undertaking on the part of Russia and Japan not to impede the development of those industrial and commercial activities, respectively, of Japan in Korea and of Russia in Manchuria, which are not inconsistent with the stipulations of Article I of this Agreement.

"An additional engagement on the part of Russia not to impede the eventual extension of the Korean Railway into Southern Manchuria so as to connect with the Eastern Chinese and Shan-kai-kwan - Niu-chwang lines.

"4. A reciprocal engagement that in case it should be found necessary to send troops by Japan to Korea, or by Russia to Manchuria, for the purpose of protecting the interests mentioned in Article 2 of this Agreement, or of suppressing insurrection or disorder liable to create international complications, the troops so sent are in no case to exceed the actual number required and are to be forthwith recalled as soon as their missions are accomplished.

"5. The recognition on the part of Russia of the exclusive right of Japan to give advice and assistance in the interest of reform and good government in Korea, including necessary military assistance.

"6. This Agreement to supersede all previous arrangenents between Japan and Russia respecting Korea." 87

The essential features of these proposals were: (I) A mutual engagement to respect the independence and territorial integrity of the Chinese and Korean empires, and to maintain the "open door" in these countries; and (2) a reciprocal recognition of Japan's preponderating interests in

${ }^{87}$ Dispatch No. 3 of the Correspondence cited above. Cf. Asakawa, pp. 303-04. 
Korea and of Russia's special interests in Manchuria. ${ }^{88}$ These demands were never materially altered by Japan during the negotiations, and their persistent rejection by Rus$\mathrm{sia}^{89}$ together with her delay in replying and her preparations for war, finally precipitated the struggle.

After a delay of eight weeks, the seat of negotiations having, in the meantime, at the request of Russia, been transferred from St. Petersburg to Tokio, in order that Admiral Alexieff might be more freely consulted, Russia presented the following counter-note to the Japanese Government, through Baron Rosen, the Russian Minister at Tokio, on October 3, 1903:

"I. Mutual engagement to respect the independence and territorial integrity of the Korean Empire.

“2. Recognition by Russia of Japan's preponderating interests in Korea, and of the right of Japan to give advice and assistance to Korea tending to improve the civil administration of the Empire without infringing the stipulations of Article I.

"3. Engagement on the part of Russia not to impede the commercial and industrial undertakings of Japan in Korea, nor to oppose any measures taken for the purpose of protecting them, so long as such measures do not infringe the stipulations of Article I.

"4. Recognition of the right of Japan to send, for the sane purpose, troops to Korea, with the knowledge of Russia, but their number not to exceed that actually required, and with the

* It may be said that Japan demanded more in Korea than she was willing to concede to Russia in Manchuria. This is undoubtedly true, but she appears to have been justified therein by conditions in Korea and the greater proximity and vitality of her interests there.

The charge made by the Russian Government in its official note of February 9, I904 (see Annuaire Diplomatique de l'empire de Russe for 1905, p. 235) that "the Tokio Cabinet gave evidence of ever increasing pretensions in the course of the negotiations" can not be substantiated. 
engagement on the part of Japan to recall such troops as soon as their mission is accomplished.

"5. Mutual engagement not to use any part of the territory of Korea for strategical purposes, nor to undertake on the coasts of Korea any military works capable of menacing the freedom of navigation in the Straits of Korea.

"6. Mutual engagement to consider that part of the territory of Korea lying to the north of the thirty-ninth parallel as a neutral zone into which neither of the contracting parties shall introduce troops.

"7. Recognition by Japan of Manchuria and its littoral as in all respects outside her sphere of interest.

"8. This Agreement to supersede all previous agreements between Russia and Japan regarding Korea."»o

It will thus be seen that in these counter-proposals Russia not only reduced Japan's demands regarding Korea, but imposed new conditions upon Japan in that country. Butmost significant of all-she quietly ignored the most important part of Article I of the Japanese proposals, viz., that part which stipulated for a mutual agreement to respect the independence and territorial integrity of the Chinese Empire and to maintain the "open door" in China and Korea, and she merely retained that part which called for a "mutual agreement to respect the independence and territorial integrity of Korea." Russia not only refused to make any declarations regarding her future policy in China or Manchuria, but required Japan expressly to recognize Manchuria as "in all respects outside her sphere of interest."

In the meantime Russian activity had been increased both in Manchuria and in Korea. On August 13, I903, Admiral

*Asakawa, pp. 308-09. Dispatch No. I7, of the Correspondence. These counter-proposals were prepared by Admiral Alexieff and Baron Rosen. 
Alexieff was appointed Viceroy of the Far East. His policy appears to have been, "on the one hand, to deal with Japan's overtures lightly and leisurely, but, on the other, to hasten the establishment of Russian control in Manchuria and on the Korean frontier, so that Japan might in time be compelled to bow to the situation and accept terms dictated by Russia."91 It was probably in pursuance of this policy that M. Lessar presented six new demands at Peking on September 6 , as conditions $^{92}$ for the final evacuation of Niuchwang and Manchuria, but these were refused by the Chinese Government at the instigation of Great Britain and Japan. The conduct of the Russians in the neighborhood of Yong-am-po on the Korean frontier of the Yalu River also became more aggressive and aggravating at this time.

The Japanese statesmen having agreed upon an "irreducible minimum", Japan made several important concessions, which were communicated in a note to Baron Rosen by Baron Komura on October 30 . These included the guarantee of the freedom of the Korean Straits; the establishment of a neutral zone extending fifty kilometres on each side of the Korean-Manchurian frontier; a "mutual engagement not to impede the connection of the Korean Railway and the Eastern Chinese Railway when these railways shall have been eventually extended to the Yalu"; a reciprocal engagement not to interfere with each other's treaty rights in Korea and China; and a recognition by Japan that Manchuria is outside her sphere of special interest in return for a recognition by Russia that Korea is outside her sphere of special interest. ${ }^{93}$

${ }^{21}$ Asakawa, p. 323.

${ }^{22}$ Ibid., p. 316 . See supra, note 57 on p. 36.

${ }^{03}$ For an English translation of this note, see Asakawa, pp. 324-25. Dispatch No. 22 in the Correspondence. 
In her counter-reply, which was delayed until December I I, Russia repeated her former counter-proposals, with the omission of the clause regarding Manchuria and the insertion of the Japanese proposal relating to the connection of the Korean and Chinese Eastern Railways.

On December 2 I the Japanese Government made a third overture to Russia. Baron Komura tried to make it clear to the Russian Government that Japan desired "to bring within the purview of the proposed arrangement all those regions in the Far East where the interests of the two Empires meet." ${ }^{44} \mathrm{He}$ also presented several slight amendments to the Russian counter-proposals regarding Korea, and the total suppression of Article VI, providing for a neutral zone in northern Korea. But when the reply of Russia, which reached Tokio on January 6, I904, was received, it was found that not only was there no mention made of the territorial integrity of China in Manchuria, but that Russia again insisted upon the recognition by Japan of Manchuria and its littoral as being outside her sphere of interests. Russia now agreed to insert a clause to the effect that she would "not impede Japan nor other Powers in the enjoyment of the rights and privileges acquired by them under existing treaties with China, exclusive of the establishment of settlements," ${ }^{95}$ on condition that Japan agree not to use any part of the territory of Korea for strategical purposes, and on condition that she agree to the establishment of a neutral zone in northern Korea. ${ }^{98}$

20 Dispatch No. 35.

"The italics are the author's. Russia resisted the attempts of foreign nations to secure rights of settlement and consular appointments in Manchuria.

"For these Russian counter-proposals, see Asakawa, p. 333. Dispatch No. 38 . 
It will thus be seen that the views of the two Governments were apparently as irreconcilable as ever, but the Japanese Government made a fourth attempt to obtain a favorable reply from Russia. On January I 3 Baron Komura instructed Mr. Kurino to present a note verbale to Count Lamsdorff which contained the following modifications of the Russian counter-proposals :

I. Suppression of the clause (in Article 5) requiring Japan not to use any part of Korea for strategical purposes.

2. Suppression of the whole Article (6) concerning the establishment of a neutral zone.

3. Recognition by Japan of Manchuria and its littoral as being outside her sphere of interest, provided that Russia will engage: (a) to respect the territorial integrity of China and Manchuria; (b) to recognize the treaty rights, including those of settlement of Japan and other Powers in Manchuria; (c) to recognize Korea and its littoral as being outside her sphere of interest.

4. Recognition by Japan of Russia's special interests in Manchuria, and of the right of Russia to take measures necessary for the protection of those interests. ${ }^{97}$

An early reply to these proposals was repeatedly asked for, but the reply, which appears to have contained a reiteration of substantially the same points as the three previous ones, did not reach Tokio until February 7, or the day following the severance of diplomatic relations between Japan and Russia on February 6.

In the meantime, Russia had increased her military activity and warlike preparations in the Far East. Since April, 1903, she had dispatched 34 war vessels, aggregating about I 3,000 tonnage, to the Pacific, and by the beginning of

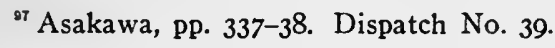


February, 1904, she had over 40,000 soldiers in Manchuria and was preparing to send over 200,000 more troops in case of need. In January, 1904, the military activity of Russia was greatly accelerated. ${ }^{98}$

On February 6, 1904, the Russian Government was notified that in view of the "obstinate rejections by Russia of Japan's proposals respecting Korea" and of the "obstinate refusal of Russia to enter into an engagement to respect China's territorial integrity in Manchuria," and in view of "Russia's repeated delays to reply without intelligible reasons and of her naval and military activities, irreconcilable with pacific aims," the Japanese Government had "no other alternative than to terminate the present futile negotiations."

"In adopting this course," so the Russian Government was informed, "the Imperial Government (of Japan) reserve to themselves the right to take such independent action as they may deem best to consolidate and defend their menaced position, as well as to protect the acquired rights and legitimate interests of the Empire." Un Under the circumstances, this severance of diplomatic relations between Russia and Japan,

${ }^{98}$ See statement published in the Press by the Japanese Government on March 3, 1904. Translated by Asakawa, pp. 352-54. It appears that Admiral Alexieff advised the Czar in December, I903, that the Japanese were preparing to send troops to Korea and establish a protectorate over that country with the consent of the Korean Government. He warned the Czar that the occupation of Korea would ruin Russia's military plans and be a menace to Port Arthur and the Russian railway system in Manchuria. In accordance with the Admiral's suggestion, and as a result of these representations, the Czar ordered Admiral Alexieff to mobilize the Far Eastern Districts and to declare a state of siege in Manchuria, at Port Arthur, and at Vladivostok, and generally to prepare for war. See London Times (weekly ed.) for June 2, 1905, p. 345 .

Asakawa, pp. 342-44. Dispatch No. 48 of the Correspondence. 
accompanied, as it was, by this ominous statement on the part of Japan, amounted to a threat of war ; and if the Russians were not prepared for the events' of February 8 and 9 (the naval engagements at Chemulpo and Port Arthur), that is evidence of culpable negligence on the part of the Russians rather than proof of a "treacherous" surprise on the part of the Japanese. 


\section{CHAPTER I}

The Outbreak of War and the Alleged Violation of Korean Neutrality

War is an abnormal relation between states, and produces abnormal conditions affecting the activities and interests of individuals as well. Consequently, its outbreak brings into existence a new set of rules affecting individuals and governments, which largely supplant or supplement those rights and obligations existing in time of peace. In view of this fact, it is extremely important to fix upon a definite date for the beginning of these new and abnormal relations between neutrals and belligerents on the one hand and the two or more belligerents on the other.

A majority of the more recent authorities ${ }^{1}$ on International Law hold that between belligerents a formal notice of intention or a declaration of war is no longer necessary prior

${ }^{1}$ A majority of the older authorities insisted upon the necessity of a declaration in some form. They were doubtless influenced by traditional views or customs which had their origin in the fetial law of the Romans or in the chivalry and ceremonies of the Middle Ages. The Romans, e. g., were very strict in their observance of certain formalities connected with the declaration of war, and they largely measured the justice or the injustice of a war by the strictness with which these formalities had been observed.

For a very extensive citation of the older authorities and historical examples, see Hall, Treatise on International Law (3rd ed.), pp. 37679, and notes. Especially interesting is the citation from Burlamaqui (note on p. 379), who naively says that "an enemy ought not to be attacked immediately after declaration of war, "otherwise the declaration would only be a vain ceremony." "This is a reductio ad absurdum of the view that a declaration of war is necessary. 
or preliminary to the outbreak of hostilities. "An act of hostility, unless it be done in the urgency of self-preservation or by way of reprisal, is in itself a full declaration of intention; any sort of previous declaration, therefore, is an empty formality unless an enemy must be given time and opportunity to put himself in a state of defence, and it is needless to say that no one asserts such quixotism to be obligatory." 2 Though the war dates from the declaration in case a declaration is made prior to an act of overt hostility, nevertheless, the date of the first actual or pronounced hostilities is, in fact, a better criterion of the commencement of a war than the date of formal declaration. For declaration is usually preceded by acts of hostility, and in such cases difficult questions are sure to arise which may lead to great uncertainty and much long and useless controversy. ${ }^{3}$

Although modern authorities ${ }^{4}$ are still somewhat divided

${ }^{2}$ Hall, op. cit., p. 374 .

"In the eighteenth century declarations were frequently published several months after letters of marque had been granted, after general reprisals had been ordered, and even after battles had been fought; and disputes in consequence took place as to whether war had begun independently of the declaration, or from the date of the declaration, or in consequence of the declaration, but so as to date, when once declared, retrospectively to the time of the first hostilities. As the legitimacy of the appropriation of private property depends upon the existence of a state of war, it is evident that conflicts of this nature were extremely embarrassing and, where different theories were in play, were altogether insoluble. To take the state of war, on the other hand, as dating from the first act of hostility, only leads to the inconvenience that in certain cases, as for example of intervention, a state of war may be legally set up through the commission of acts of hostility, which it may afterwards appear that the nation affected does not intend to resent by war; and, as in such cases the nation doing hostile acts can always refrain from the capture of private property until the question of peace or war is decided, the practical inconvenience is small." Hall, op. cit., p. 375 .

- For more or less extensive citations of the modern authorities, see Hall, op. cit., pp. 379-81, and note on p. 380 ; Calvo, IV, § I906; Pradier- 
on this question, the general practice of nations, at least since the sixteenth century, shows conclusively that declarations of war prior to the outbreak of hostilities have been comparatively rare and altogether exceptional. ${ }^{5}$ So far as

Fodéré, VI, § 2673. The French publicist, Pradier-Fodéré (VI, § 2677), is of the opinion that "if declaration is not an essential condition of a regular war, it is, at least, a useful formality which states ought not to omit." The Russian publicist, De Martens (III, p. 205), thinks that "neither proclamation nor diplomatic notice are obligatory, provided that the state of relations is such that hostilities will not be a surprise." Hostilities which constitute a surprise he characterizes as "brigandage and piracy." The German Holzendorff (Handbuch, IV, \$8 82-84) holds neither declaration nor manifesto to be necessary, although he thinks that "a belligerent ought to give notice of some sort if he can do so consistently with his political interest and his military aims." (The last two citations are given by Hall, note on p. 380 .)

French publicists appear generally to regard a formal declaration of war as necessary, and to look upon a war begun without such declaration as at least tainted with irregularity. See $e$. g., Pillet, Les Lois Actuelles de la Guerre, \& 31, pp. 64-65; Bonfils, Manuel, \$\$ 1027-32; Despagnet, Cours, pp. $549 \mathrm{ff}$; and Guelle, Précis des Lois de la Guerre, I, ch. I.

"Most of the wars of the seventeenth century began without declaration, though in some cases declarations were issued during their continuance." Hall, note on p. 377. "The nearer we approach to modern times the rarer do formal declarations become. There have been only eleven of them between civilized States since 1700, whereas the present century has seen over sixty wars or acts of reprisal begun without formal notice to the power attacked." Lawrence, Principles, p. 300 . In a compilation of cases of hostilities extending from 1700 to the present time Colonel Maurice, of the British army, found but I I out of I 8 instances in which a declaration of war preceded hostilities. Snow, Manual, p. 78. In most cases declarations have, however, followed the outbreak of hostilities.

For extensive citations of historical examples, see Hall, cited above; Phillimore, Commentaries, III, Pt. IX, ch. 5 ; Calvo, IV, \& 1908; Rivier, II, pp. 223-28. For an abstract of cases ranging from 1700 to 1870 , in which hostilities have occurred between states prior to declaration, see Maurice, Hostilities without Declaration of War (1883), and a review of this work by Prof. Holland in the Revue de Droit International, 1885, No. 6, pp. 63-65. See also Des Hostilités sans Declaration de 
the writer is aware, judges of prize courts (at least in the United States and England), who have been called upon to pass upon the validity of captures made prior to the declaration of war, are unanimously of the opinion that war may exist without a declaration. ${ }^{6}$

The utmost that nations in a state of peace have a right to demand is that they shall not be suddenly surprised or treacherously attacked without any intimation or warning whatsoever. But "the use of a declaration does not exclude surprise"; it only "provides that notice shall be served an infinitesimal space of time before a blow is struck. . . . The truth is that no forms give security against disloyal conduct, and that when no disloyalty occurs states always sufficiently well know when they stand on the brink of war."? War is usually preceded by a long period of negotiations, which generally, although not necessarily, terminates in an

Guerre, by M. Feraud-Giraud in the same review for I885, No. I, pp. I9 ff, and Owen, Declaration of War, 1899 .

It should perhaps be noted that recent wars seem to have witnessed a return to the older practice, e. g., those of 1870 and 1877 . The practical futility of the declaration of 1877 is, however, shown by the fact that Turkish territory was invaded by Russia on the day of her declaration of war on April 24, 1877. In the Chino-Japanese War of 1894-5, hostilities were begun before the declaration, and in our own recent war with Spain war was formally declared on April 25, 1898, after the capture of several Spanish vessels and the blockade of the Cuban ports on the 22nd of April. The existence of hostilities was dated back to the 21st of April by the Declaration itself.

- See, e. g., the opinion of Lord Stowell in I Dodson, 247; of Sir W. Scott in the case of the Eliza Ann, I Dodson, 244; The U. S. Supreme Court in Bas v. Tingy, 4 Dallas, 37, and in The Prize Cases, 2 Black, 635; Justice Sprague in The Amy Warwick, 2 Sprague, 123; Lord Chief Justice Mellish in the Teutonia, 4 Privy Council Reports, 171; and Judge Locke in the Panama, 87 Fed. Rep. 927.

${ }^{7}$ Hall (3d ed.), p. 38I. See also Lawrence, pp. 30I-02; Woolsey (6th ed.), pp. 189-90; Walker, The Science of International Law, p. 242; Pradier-Fodéré, VI, \& 2676; Rivier, II, p. 222; Funck-Brentano and Sorel, Précis, p. 245; De Martens, Traité, III, p. 205. 
ultimatum. Moreover, with modern facilities for telegraphic communication, a complete surprise would be wellnigh impossible.

The mere recall and dismissal of ambassadors or ministers, or, in other words, the breaking off of diplomatic relations, is not and ought not in itself to be regarded as equivalent to a declaration of a state of war $;^{8}$ but such acts indicate that the relations between the states in question are very much strained or altered, and they often form a sort of transition from a state of peace to that of war. They are generally preceded by an ultimatum or final note, which usually prescribes a definite time within which a favorable answer must be returned in order to prevent a resort to force. In such cases the ultimatum amounts to a conditional declaration of war, $i$. e., conditional upon the rejection of the terms proposed, or a failure to accept them within the time specified.

The foregoing rules or customs are so well known to students of International Law, and their practice is so generally observed by modern states, that it might perhaps be deemed unnecessary to restate them here were it not for the charges of "treachery," "piracy," "bad faith," and "breach of International Law" which were made in certain quarters -high as well as low-against Japan in consequence of the Japanese attack upon the Russian fleets at Chemulpo and Port Arthur on February 8 and 9 prior to the formal declaration of war against Russia on February IO, 1904. Not only were these charges noised abroad by the apparently unanimous voice of the French and the Russian Press, but similar accusations have been made by leading authori-

${ }^{8}$ Pradier-Fodéré, VI, § 2678; Rivier, II, p. 220; Funck-Brentano and Sorel, p. 243. 
ties on International Law in France and Russia. ${ }^{9} \quad$ Most serious of all, the Czar himself was made the mouthpiece of these charges, which were presented to the whole world through the medium of the Czar's formal Manifesto of February Io and through Count Lamsdorff's Circular Note to the Powers of February 22, $1904 .^{10}$

A brief review of the facts ought to convince the most prejudiced or the most skeptical that the conduct of Japan in this matter was entirely correct. It is not our intention in this connection to enter upon a discussion of the causes of this war with reference to their justice or injustice. International Law, as such, is indifferent to causes. It does not consider the justice or injustice of a war. From the purely legal standpoint, all wars are equally just or unjust; or, properly speaking, they are neither just nor unjust. International Law merely takes cognizance of the existence of war as a fact, and prescribes certain rules and regulations which affect the rights and duties of neutrals and belligerents during its continuance. The justice of war in general or of a certain war in particular are questions of the gravest importance and of the most vital interest, but they belong to the domain of international ethics or morality rather than to that of International Law. ${ }^{11}$

- See, e. g., H. Ebren and F. de Martens in the Revue Générale de Droit International Public for March-April, 1904, pp. 134 and 149.

10 For these documents, see London Times (weekly ed.) for February 12 and 26,1904 .

${ }^{13}$ Bluntschli (Droit International Codifié, 5th ed., $§ 515$, p. 293) expresses a different view. He says, "War is just when International Law authorizes recourse to arms; unjust when it is contrary to the principles of law." He adds in a note: "This principle is not only a rule of morality, it is a true principle of law." He admits, however, that it has no great practical value, inasmuch as each of the belligerents is sure 
In order to justify the propriety and validity of the Japanese attack upon the Russian fleets from the standpoint of International Law, it is enough for us to show that all peaceful or diplomatic relations between Japan and Russia had been severed a sufficient time before the attack, and under such circumstances as to guard against all reasonable danger of surprise. It must have been manifest to all concerned for months prior to the outbreak of hostilities that war was inevitable unless important concessions should be effected or a compromise agreed upon, which neither state seemed willing to make. Obviously this fact was realized at St. Petersburg as well as at Tokio, and the long Russian delays ${ }^{12}$ in answering the Japanese notes during the period of negotiation which preceded the outbreak of hostilities can hardly be explained on any other theory than that Russia desired time for the completion of her military preparations and the concentration of her land and naval forces. ${ }^{13}$ The Russian reply to the last Japanese note of January I3, I904, had not been received at Tokio by February 6 , in spite of a request on the part of the Japanese Government for a prompt response on account of the gravity of the situation, and in spite

to affirm the justice of its cause, and because there is no judge to pronounce upon the value of these assertions.

But, as Funck-Brentano and Sorel (Précis, p. 232, 2nd ed.) say, "It is only an abuse of words, in relying upon the law of nations, to qualify wars as just or unjust. The law of nations only considers states in their relations with one another. . . . It is with wars between states as with combats between men, they only begin when all notion of reciprocal right and justice ceases. . . War is a political act. . . ."

${ }_{12}$ The Japanese proposal of August 12, 1903, was not answered by a counter-proposal until October $3 \mathrm{~d}$. The answer to the Japanese proposal of October 3oth was delayed until December II, I903.

${ }^{13}$ For evidence on this head, see the Japanese reply to the Russian charges in the London Times (weekly ed.) for March 4, 1904. This reply is reprinted in Asakawa, pp. 352-54. 
of the repeated requests for an answer on the part of $\mathrm{Mr}$. Kurino, the Japanese Minister at St. Petersburg. ${ }^{14}$

Under these circumstances the only matter for astonishment is that the Japanese Government should have delayed so long, unless it, too, required more time for military preparations. It is therefore no cause for adverse criticism that diplomatic relations with Russia were abruptly severed on February 6. The Russian Government was informed that "in the presence of delays which remain largely unexplained, and naval and military activities which it is difficult to reconcile with entirely pacific aims, . . . the Imperial Government (of Japan) have no other alternative than to terminate the present futile negotiations. In adopting this course the Imperial Government reserve to themselves the right to take such independent action as they may deem best to consolidate and defend their menaced position, as well as to protect their established rights and legitimate interests." 15 This was undoubtedly a sufficient declaration of intention on the part of the Japanese Government, and if the Russian fleet or the Russian Government allowed themselves to be surprised after such a plain, albeit diplomatic, intimation of hostile intention, the fault, if any, can certainly not be laid at the door of Japan. Russia can hardly be accused of such

${ }^{14}$ See the Japanese statement of the case in the London Times (weekly ed.) for February I2, 1904. So far as I am aware, the Russian Government has not denied these facts. The burden of the Russian complaint was that Japan did not await the receipt of the last Russian note which, it is alleged, was on the way to Tokio at the moment of the rupture of diplomatic relations. But it is not alleged that this note conceded any appreciable portion of the Japanese demands. For the Russian statement of the case, see Annuaire Diplomatique de l'Empire de Russe, pp. 255 ff.

${ }^{15}$ See N. Y. Times for February 13, 1904. The italics are the author's. 
ignorance or inexperience of the methods of modern diplomacy as is implied in her complaint that Japan began the attack on Port Arthur without "previously notifying (us) that the rupture implied the beginning of warlike action."16

The Japanese attack on the Russian fleets at Chemulpo and Port Arthur occurred on February 8 and $9,{ }^{17} i$. e., over two days after Mr. Kurino, the Japanese Minister at St. Petersburg, had informed the Russian Government that Japan had decided to sever diplomatic intercourse with Russia, and that she reserved to herself the right to "take such independent action" as was deemed proper for the consolidation and defence of her menaced position and the protection of her rights and interests. Surely there was less cause for the charges of "surprise," "bad faith," and "treachery" than if Japan had patiently awaited the Russian note, carefully preserved the appearance of diplomatic relations, then suddenly declared war, and immediately followed this declaration by an attack on the Russian fleet. ${ }^{18}$

At the same time Russia also complained of another alleged serious infraction of International Law on the part of Japan-viz., of the violation of the neutrality of Korea. In a Circular Note to the Powers, sent on February 22, I904, Count Lamsdorff charged Japan with "an open violation of all customary laws governing the mutual relations between

${ }^{10}$ See the Czar's Manifesto, in the London Times (weekly ed.) for February 12, 1904.

${ }^{17}$ It is claimed by the Japanese that the first shot of the war was fired by a Russian vessel, the Korietz, at Chemulpo; but this point is entirely immaterial, inasmuch as it was Japan that made the first aggressive movement.

${ }^{18}$ For an able defense of Japan's conduct in this matter, see Lawrence, War and Neutrality in the Far East, ch. 2. For the negotiations and documents bearing on the case, see M. H. Nagaoka in the Revue de Droit International for 1904, No. 5, VI (deuxième série), pp. 46I ff. 
civilized nations." "Without specifying each particular violation of these laws on the part of Japan," he called the serious attention of the Powers to the acts committed by the Japanese Government with respect to Korea, the "independence and integrity" of which "was recognized by all the Powers." In thus violating the neutrality of Korea, Japan was accused, not only of a violation of treaties, but of a "flagrant breach of International Law," as well. ${ }^{19}$ The captains of the three English, French, and Italian war vessels lying in the harbor of Chemulpo at the time of the attack also protested "energetically" against "such a violation of neutrality." 20

There can be no doubt but that, according to the strict letter of the law, Japan was guilty of a violation of one of the most fundamental rules of International Law,-viz., the right of an independent state to remain neutral during a war between other members of the family of nations, ${ }^{21}$ and to have its neutrality and territorial sovereignty respected by the belligerent states. On the other hand, as the Japanese Government was careful to point out in its official reply to

10 The Japanese claim, however, that it was Russia who first violated the neutrality of Korea by sending troops across the Yalu on February 2. See London Times (weekly ed.) for April I, I904.

${ }^{2}$ The Russian Press showed considerable irritation over the fact that Captain Marshall, the commander of the American gunboat Vicksburg, did not join in this protest of the three captains. As a matter of fact, the American captain was not asked to join in the protest, his determination to preserve a strictly neutral attitude being well known. The conduct of Captain Marshall appears to have been entirely correct, more so, in fact, than was that of the other three captains. For his reply to the charges made by M. Pavloff, the Russian minister in Korea, see House Doc., 58th Congress, 3d session (For. Rel., 1904), pp. 782 ff.

${ }^{21}$ This right was scarcely recognized in practice before the modern period, and it has often been violated even in modern times; but it may now be regarded as one of the best-established and most fundamental rules of International Law. 
the Russian note, "the maintenance of the independence and territorial integrity of Korea is one of the objects of the war, and, therefore, the dispatch of troops to the menaced territory was a matter of right and necessity, which had the distinct consent of the Korean Government."22

This seems to be one of those not altogether rare although exceptional cases where reasons of policy or motives of national interest, if not the necessity of self-preservation, intervene to prevent a strict observance, or necessitate a positive violation of law. Japan had long since included Korea within her political "sphere of influence" or protection, and Korea was one of the main objects of the war. It was, therefore, just as impossible for Japan to respect the neutrality of Korea after the opening or in contemplation of hostilities as it would be impossible for the United States to respect the neutrality of a Spanish-American state under similar circumstances, e.g., if threatened by a European Power. The complaints of Russia on this score, although theoretically sound, were therefore practically absurd. Korea, although in theory sovereign and independent since I876-82, was really a dependent state under the protection of Japan.

Russia's real motive in entering this protest is probably to be found in the conclusion of Count Lamsdorff's note. "At the same time, the Imperial Government (of Russia) considers it necessary to issue a timely warning that, owing to Japan's illegal assumption of power in Korea, the Government declares all orders and declarations which may be issued on the part of the Korean Government to be invalid." In order to raise her position in Korea above that of a mere

\footnotetext{
${ }^{22}$ See the London Times (weekly ed.) for March II, I904.
} 
military occupant on the one hand or of a vulgar conqueror on the other, Japan negotiated a treaty with the Korean Government in which she guaranteed the "independence and integrity of the Korean Empire" (Art. III), and agreed to protect Korea against the "aggressions of a third Power or internal disturbances." 23

The Russian Government claimed that this treaty was invalid because made under duress. ${ }^{24}$ This raises a very interesting question in International Law. Was the duress here alleged of such sort as to render the treaty and all acts performed under its sanction invalid? The rule which applies in such cases is perfectly clear, although we are not fully informed as to the facts in this particular instance. One of the antecedent conditions upon which the validity of a treaty depends is "freedom of consent." But "the freedom of consent, which in principle is held as necessary to the validity of contracts between states as it is to those between individuals, is understood to exist as between the former under conditions which would not be thought compatible with it where individuals are concerned. In International Law force and intimidation are permitted means of obtaining redress for wrongs, and it is impossible to look upon permitted means as vitiating the agreement, made in consequence of their use, by which redress is provided for. Consent, therefore, is conceived to be freely given in interna-

${ }^{23}$ See the London Times (weekly ed.) for March 4, 1904, for the text of the treaty between Japan and Korea. See also Asakawa, pp. 367-68.

${ }^{24}$ The Russian Novosti published a statement from the Minister of Foreign Affairs declaring that "Russia does not consider Korea as a belligerent state, but simply as a neutral state, acting under violent pressure from Japan and deprived of the power of free action." For this reason, it is said, "Russia can not regard as valid any treaty concluded by Korea for the benefit of Japan, nor any abrogation of Russian concessions." See London Times for March 25, 1904. 
tional contracts, notwithstanding that it may have been obtained by force, so long as nothing more is exacted than it may be supposed that a state would consent to give, if it were willing to afford compensation for past wrongs and security against the future commission of wrongful acts. And as International Law can not measure what is due in a given case, or what is necessary for the protection of a state which declares itself to be in danger, it regards all contracts as valid, notwithstanding the use of force and intimidation, which do not destroy the independence of the state which has been obliged to enter into them. When this point, however, is passed, constraint vitiates the agreement, because it can not be supposed that a state would voluntarily commit suicide by way of reparation or as a measure of protection to another. The doctrine is, of course, one which gives a legal sanction to an infinite number of agreements, one of the parties to each of which has no real freedom of will; but it is obvious that unless a considerable degree of intimidation is allowed to be consistent with the validity of contracts, few treaties made at the end of a war or to avert one would be binding, and the conflicts of states would end only with the subjugation of one of the combatants or the utter exhaustion of both." 25

In the treaty between Japan and Korea above referred to, the "independence and territorial integrity" of Korea was carefully and explicitly provided for, so that there can be no objection to the validity of the treaty on this score.

"The only kind of duress which justifies a breach of treaty is the coercion of a sovereign or plenipotentiary to such an extent as to induce him to enter into arrangements which he

${ }^{25}$ Hall, op. cit., 3d ed., pp. 325-26. 
would never have made but for fear on account of his personal safety. Such was the renunciation of the Spanish crown extorted by Napoleon at Bayonne, in 1897, from Charles IV and his son, Ferdinand. The people of Spain broke no faith when they refused to be bound by it and rose in insurrection against Joseph Bonaparte, who had been placed upon the throne." ${ }^{26}$ So far as the writer is aware, it is not alleged that Japan used such methods of coercion in the case of this treaty with Korea. ${ }^{27}$

At the very outset of the war an extremely interesting question arose in respect to the proper treatment of the sailors of the Russian vessels (the Korietz and the Variag) whose crews had been rescued at Chemulpo by neutral cruisers of various nationalities ${ }^{28}$ on February 8 , 1904. The

${ }^{2}$ Lawrence, Principles, pp. 287-88. Cf. Hall, p. 326; Bluntschli, 8409 ; Rivier, II, p. 55 ; Bonfils-Fauchille, \$ 818, and Despagnet, \& 455 . For an interesting discussion of Korean neutrality, see Lawrence, $W a r$ and Neutrality ( $2 \mathrm{~d}$ ed.), ch. Ir.

${ }^{27}$ The same statement can not be made in respect to the Convention of November 17, 1905. In the case of the latter treaty, it is charged that the signatures of the Emperor of Korea and of the Korean ministers were obtained by the Marquis Ito and Mr. Hayashi, the Japanese Plenipotentiaries, as a result of force and intimidation due to the presence of Japanese soldiers. See London Times for December 5, 1905. This treaty was also invalid from a strictly legal point of view for another reason. It formally extinguished the independence of Korea by transforming this country into a protectorate, for the conduct of Korean foreign affairs was placed under the control and direction of representatives of the Japanese Government. For the text of this treaty, see Archives Diplomatiques, 3d series, Vol. 96, p. 363. For an interesting article on "The International Status of Korea," see F. Rey in Revue Générale de Droit Int. Pub. for I906, pp. 40-58.

These were the French cruiser Pascal, the British cruiser Talbot, the Italian cruiser Elba, and the American gunboat Vicksburg. The charge made by the Russian newspapers that Captain Marshall, the commander of the Vicksburg, refused to assist in taking care of the Russian wounded was admitted to be false by the Russians themselves. It is true that none of the Russian wounded were received on board the 
Japanese, who seem to have feared that the rescued sailors would be surrendered to the Russians, at first demanded their surrender as prisoners of war; but the neutral commanders objected, and the British Government at first insisted upon taking those in its possession into British territory, with a view of interning them until the close of the war, or until other arrangements could be made. The Japanese Government, however, at last generously consented to their release on parole, and the rescued sailors were handed over to the Russians outside the theatre of hostilities. A wise and easy solution of what seemed for a time a very perplexing problem was thus reached. In the event of an unwillingness on the part of the Japanese Government to consent to such an arrangement, the obligations of neutrality would probably have been best fulfilled by interning the rescued sailors in neutral territory until the close of the war, in accordance with Premier Balfour's suggestion to the British Parliament. ${ }^{29}$ This is now universally admitted to be the proper course to pursue in the analogous case of an army which has been forced to retreat into neutral territory. ${ }^{\mathbf{3 0}}$ The surrender of these sailors to Russia under the circumstances would have furnished a just cause for protest on the

Vicksburg, but Captain Marshall had good reason for his action. See House Doc. cited in footnote on p. 71, supra.

${ }^{20}$ See the New York Evening Post for February 25, 1904 (semiweekly ed.).

${ }^{20}$ See Art. 57 of the "Laws and Customs of War" adopted by the Hague Conference of 1899 . Holls, Peace Conference, p. 160. The Hague Conference failed, however, to agree upon a proper disposition of shipwrecked, wounded, or sick belligerents landed at a neutral port or rescued by neutral ships of war. For a fuller discussion of this subject, see Lawrence, $W$ ar and Neutrality, ch. 4; Holls, op. cit., pp. 127-132 and pp. 504-506; and Latané, "The Use of Neutral Waters by Belligerents" in the Proceedings of the American Political Science Association, Vol. II (1905). 
part of Japan, and might have tended in future wars either to discourage rescue from a sense of humanity on the one hand, or to have encouraged it from motives of partiality on the other. ${ }^{31}$

"The treatment of the rescued crews of the Korietz and the Variag may prove a valuable precedent in future wars.

A different course was followed by the British Government during the Civil War, in the famous case of the Deerhound-a private yacht belonging to the Royal Yacht Association of England. The owner of this yacht, acting at the request of Captain Winslow, of the Kearsarge, helped to rescue the officers and crew of the Alabama upon the occasion of the latter's sinking at the hands of the Kearsarge. To the surprise of Captain Winslow, the Deerhound, after picking up a certain number of men, largely officers (including Captain Semmes) of the Alabama, hastily and surreptitiously steamed off with its precious cargo to Southampton. Several of these men had already surrendered themselves to the Kearsarge as prisoners of war, and there was some evidence of collusion between Captain Semmes and the owner of the Deerhound. To be sure, the Deerhound was a private yacht instead of a warship, but she seems to have had a sort of semi-official character as a boat belonging to the Royal Yacht Association. In any case, the British Government would probably have best performed its neutral duties by interning the officers and men of the Alabama as prisoners of war. For the facts of the case, see the Claims Against Great Britain, Vol. III, pp. 26I308 (1st sess. 4Ist Cong. 1869). For a somewhat different view of the law and the facts than that given above, see Bernard, The Neutrality of Great Britain During the American Civil War, pp. 429-30. 


\section{CHAPTER II}

The Conduct of the United States in Respect to Its Neutral Rights and Duties

The Government and people of the United States are able to show a remarkably clear and consistent record in the performance of their neutral duties toward both belligerents during the Russo-Japanese War. ${ }^{1}$

A loud outcry was raised by the Russian Press late in February, 1904, in consequence of a report that an application had been made to the United States by the Commercial Cable Company (presumably acting in the interest of Japan) for permission to connect Japan with Guam and the Philippine Islands (and thus with the rest of the world) by means of a submarine cable, it being feared that the two existing cables connecting Nagasaki with Shanghai would be cut by the Russians. In the latter case Japan would have been cut off from telegraphic communication with the rest of the world.

In Russia the view prevailed that the granting of such a permit by the United States would constitute a breach of neutrality, although there seems to have been no official intimation or expression of opinion to this effect on the part of the Russian Government. Our Government appears to have been similarly non-committal. In reply to an informal

${ }^{1}$ The same may be affirmed of England, but can hardly be said of Germany and France. The charges against Germany and France will be considered in subsequent chapters. 
inquiry by Count Cassini, the Russian ambassador at Washington, as to the truth of this report, Secretary Hay denied that the United States Government was considering such an application. ${ }^{2}$

The legality or propriety of laying such a cable would probably depend upon the question of fact as to whether it were an enterprise in which the animus vendendi or the animus belligerandi predominated. During the Spanish-American War in 1898 , the British authorities refused a request from the United States to lay a cable between Manila and Hong Kong, such a cable being obviously intended primarily for military use.

In the earlier period of the war there were frequent comments in the Russian newspapers on what was called "American meddling." These charges seem to have been inspired mainly by the pro-Japanese tone of the American press, and also by the interest manifested by the Government and people of the United States in the fate of China. It goes without saying that expressions of opinion and sympathy on the part of neutral individuals, or of the newspapers, or even of public meetings, in behalf of either belligerent do not constitute a violation of neutrality. No government can be required to interfere with such free expression of opinion or sympathy, and it is not desirable in a land animated by the traditions and spirit of freedom that such an attempt should be made. It is a mere confusion of ideas to pretend, as some people in this country seemed to imagine during the war, that because it was the duty of our Government to observe the obligations of neutrality, it was also our duty as a people to affect indifference toward both belligerents in the

${ }^{2}$ See Chicago Record-Herald for March 2, 1904. 
struggle. " "Neutrality," says a well-known French publicist, "is not impassibility. It merely implies abstention from external acts which may favor one of the belligerents during hostilities; it does not exclude an expression of opinion upon the politics (which may be either praiseworthy or blamable) of such a state. In certain cases, one should even regard it as a human and international duty to sympathize with a state, the rights of which are injured by an abuse of force, and to morally encourage it."4

American sympathy for Japan appears also to have sought expression in several practical ways.

For example, it was announced in February, 1904, that sixty residents of Chicago (among them a number of veterans of the Spanish-American War) intended to sail for the Orient with the intention of enlisting in the Japanese army, in spite of the announcement by Japan to the effect that she desired no foreign troops, and numerous applications are said to have been made by American citizens for permission to enter the military and naval service of Japan.

It was also reported in February, 1904, that there was a movement on foot in Atlanta, Georgia, to procure a warship and present it to the Japanese Government.

At a mass meeting held in New York on February I2, I904 (at which the majority of those present were Japanese, but which was also attended by a number of American citizens), a committee reported in favor of raising a Japanese war-fund of $\$ 5,000,000$ by loans, gifts and contributions to the Red Cross Society. The question was raised as to

: Slightly adapted from an editorial in the London Times (weekly ed.) for March 7, 1904. For some official utterances of American statesmen on this head, see Wharton's Digest, III, $\$ 389$.

- Kleen, Lois et Usages de la Neutralité, t. I., p. 218. 
whether American sympathizers could contribute to the Japanese war-fund without violating the neutrality laws of the United States or the obligations of International Law. The Japanese Consul-General, Mr. Uchida, is reported to have said that he thought this point had not been definitely settled, although he declared that he would be ready to receive contributions; but he was of the opinion that there could be no legal objection to the purchase of Japanese war bonds as an investment, and he said that there was no question but that Americans could donate as much as they liked to the Japanese Red Cross Society. ${ }^{5}$

In a communication dated May 5, 1904, Secretary Hay notified Mr. Takahira that the Commandant at the Mare Island Navy Yard had been instructed not to forward to Japanese serving in the United States Navy certain circulars, contained in envelopes sent out from the ConsulateGeneral of Japan at New York, soliciting subscriptions to Japanese bonds, contributions to the relief fund for Japanese soldiers and sailors, and aid for the Red Cross Society of Japan. "While Japanese in the United States doubtless have the right to subscribe to Japanese bonds or to contribute to relief and Red Cross Society funds in Japan, yet it is undesirable that such contributions should be sought through the naval official channels of this Government." 6

The successful floating of large Japanese war loans in England and the United States, as also the successful float-

- For a report of this meeting, see New York Times, for February I3, 1904. Mr. Takahira, the Japanese minister at Washington, is said to have received numerous offers of large contributions to the Japanese war fund from Americans. The writer does not know whether any of these were accepted.

'House Doc. of the 58th Congress, 3d session (Foreign Relations, 1904), pp. 427-428. 
ing of still larger Russian loans in France, also raises the question as to the legality of such loans.

As to the legality of foreign enlistment, the acceptance on the part of a British subject, without a license from His Majesty, of any commission or engagement from a belligerent state is forbidden, under penalty of fine and imprisonment, by the British Foreign Enlistment Act of 1870, whether such engagement takes place within or without His Majesty's dominions; but our own neutrality laws ${ }^{7}$ merely prohibit foreign enlistment or the acceptance of a foreign commission within the territory or jurisdiction of the United States. But the municipal laws of a state are not necessarily the correct measure or standard of its international obligations, and it is at least doubtful whether the requirements of International Law in the matter of enlistment within neutral jurisdiction are even as stringent as are those of our Neutrality Act of $1818 .^{8}$ "It is not the duty of a neutral government to prohibit the enlistment of its subjects in the service of a foreign belligerent, such enlistment taking place beyond its territorial jurisdiction. The neutral ruler may punish by municipal penalty a subject so engaging, but, in default of treaty stipulation, he is under no international obligation so to do."

The levying of troops within the borders of a neutral

They also prohibit any person from hiring any person to enlist or from hiring another to go beyond the jurisdiction of the United States with intent to be enlisted. It would not be a violation of our neutrality laws merely to leave this country with intent to enlist. $U$. $S$. v. Kazinski, 2 Sprague 7. For official opinions on the subject of enlistment, see Wharton's Digest, III, §392.

- The requirements of International Law are certainly not as stringent as are those of the British Foreign Enlistment Act of 1870.

- Walker, The Science of International Laze, p. 446. 
state, or "anything like recruiting on a large scale,"10 is distinctly forbidden in modern times by the law of nations, and the failure to prevent these things would constitute a serious breach of neutrality; but on the other hand, "a state is not expected to take precautions against the commission of microscopic injuries."11 "It is not implied for a moment that the government of a neutral country is obliged to keep watch over each unit of its population, and (that it) can be made responsible if a man here and another there crosses its frontier for the purpose of taking service with a belligerent." ${ }^{2}$ Besides, although there is no right of expatriation known to International Law, it is always open to any individual to renounce his nationality and enroll himself as a citizen or to enter the service of another state. The failure of the United States Government to prevent the departure of a certain number of her citizens for the Orient and the enlistment of these in the Japanese army could not have been made a serious ground for complaint on the part of Russia, and such conduct on the part of our citizens would not even have been a violation of our own neutrality laws. On the other hand, our Government could not have permitted the levying or recruiting of troops in this country by agents or friends of the Japanese Government.

Our neutrality laws also forbid any one from fitting out and arming, or knowingly being concerned in the procuring, furnishing, fitting out or arming of any vessel, with intent that such vessel shall be employed in belligerent service. Since the incorporation of this principle in the Treaty of Washington in I87 I and the Geneva Award of 1872 , no one

\footnotetext{
${ }^{10}$ Lawrence, Principles, p. 533.

${ }^{11}$ Hall, Treatise, p. 601 .

${ }^{22}$ Law rence, op. cit., p. 533.
} 
is likely much longer to deny that this rule forms an integral part of International Law; and the proposal to present Japan with a war-vessel, if made, was on the face of it absurd. The Government of the United States would have been bound by its international obligations to have prevented the fitting out, arming, and the equipping within its jurisdiction, as well as the departure, of such a vessel, and every contributor to such a fund would have been liable to arrest and punishment for a violation of the Neutrality Act of 1818 .

"The duties of neutrals happily do not impose any checks upon the humane impulses of the citizens of neutral countries, or upon the practical expression of their sympathies in case of the wounded, the widows, and the fatherless;"13 and there can be no sound objection to contributions to any Red Cross Society, at least on the part of neutral individuals.

As to the question whether American sympathizers with Japan had a right to make gifts or voluntary contributions to a fund set aside for the purpose of assisting Japan to carry on the war, the case is by no means so clear. There can, however, be no real question as to the legality of the purchase of war-bonds as an investment. Of course, it would be a flagrant breach of International Law if such a loan were in any way to be advanced, supported, or guaranteed by a neutral government. Although the legality of loans by neutral individuals to belligerent states has been denied by some eminent publicists, ${ }^{14}$ such a position is not in conformity

${ }^{13}$ From an editorial in the London Times for February $13,1904$.

${ }^{14}$ E. g., by Bluntschli, \& 768; Phillimore, III, \& 151 ; Calvo, \$8 262830 (5th ed.) ; and Halleck (Baker's ed.), II, p. r95. The cases De Wutz v. Hendricks, Common Pleas, 1824, 9 Moore, 586; Thompson v. Powles, Chancery, 1828, 2 Simon, 194; and Kennet v. Chambers, U. S. Supreme Court, 14 Howard 38 , upon which the view of these publicists seems to be founded, merely go to the extent of holding that contracts to raise 
with the practice of nations. "Money is a form of merchandise, and neutral individuals constantly trade in it with belligerent governments. It can be transferred with the greatest ease, far more easily, in fact, than other commodities. Commercial transactions in it could not be prevented, except by an amount of espionage and interference which would outrage human nature and render all trade impossible. No war of any magnitude takes place without a free resort by the combatant powers to neutral money markets. The stock in loans issued to provide funds for the conflict is bought and sold in other countries, just as freely as shares in foreign mines and railways. . . . When practice points entirely in one direction, it is idle to pit against it a so-called rule based on nothing better than the statement that gold is a prime necessity in war. It certainly is; and nearly all agree that a belligerent may lawfully confiscate any supplies of it he may find in a neutral vessel on its way to the enemy. Money is contraband of war, and must be treated like other articles in the same category. The neutral trader in it lends at his own risk, but he commits no breach of the common law of nations by lending, and his government is under no obligation to attempt the impossible task of preventing him.".15

loans for the purpose of aiding communities whose belligerency or independence has not been recognized are illegal or invalid. This is a good example of the excessive deference which is sometimes paid to the decisions of judges whose opinions are often mere obiter dicta or are given a more extended application than they deserve. In dealing with the decisions of courts we should always remember that they are necessarily of limited application, both as to subject-matter and in respect to nationality. We should never forget that International Law is based upon the general practice of nations. This is one of the gravest objections to the teaching of International Law mainly or exclusively by the use of the "case system."

${ }^{25}$ Lawrence, Principles, pp. 522-23. Cf. Hall, p. 598. 
But it is claimed that gifts or voluntary subscriptions stand upon a different footing from ordinary loans. In 1823 the law officers of the British Crown, in response to an inquiry from the British Cabinet in respect to the legality of certain funds which were being raised in behalf of the Greek revolutionists whose belligerency had been recognized by the British Government, gave an opinion to the effect that "voluntary subscriptions of the nature alluded to were inconsistent with neutrality and contrary to the law of nations." "1s In commenting upon this opinion, Lawrence says: "Even in deciding, and rightly deciding, that voluntary gifts and subscriptions were illegal, the British law officers took care to add that the belligerent against whom they were directed would not have the right to consider them as constituting an act of hostility on the part of the neutral government. Moreover, they abstained from recommending a prosecution of the subscribers, upon the ground that it would be almost certain to fail." 17

But of what use, we may ask, is a prohibition in International Law which can not be made effective, or a rule for the non-enforcement of which a neutral state can not be held responsible? The only apparently sound argument in favor of such a rule which occurs to the writer is one based upon the doctrine of intent. It might be urged that we ought to distinguish, as in the case of the sale, construction, or exportation of a war-ship, between a bona fide commercial transaction and an intent to render assistance to one of

${ }^{26}$ For the documents, see Halleck (Baker's ed.) II, pp. 195-97. But with respect to loans, the learned lawyers declared that "if entered into merely with commercial views, we think, according to the opinion of writers on the law of nations and the practice which has prevailed, they would not be an infringement of neutrality."

${ }^{17}$ Lawrence, op. cit., pp. 523-24. 
the belligerents. But the rules of International Law have fortunately not been devised to satisfy the demands of logic or of any system of classification, and the doctrine of intent, at least as applied to ships of war, ${ }^{18}$ is one of very doubtful value and validity. For, as an able writer has well said, "in international wrongs . . . the intent is not the thing chiefly or primarily regarded." 10

So far as can be ascertained, the people and Government of the United States fully discharged their neutral obligations toward both belligerents during the war. President Roosevelt's Proclamation of Neutrality, issued on February ro, 1904, was more than usually full and explicit, and it took advanced ground on all important questions. In accordance with the terms of our neutrality laws, the acceptance of commissions and enlistment in the military or naval service of either belligerent were strictly forbidden. ${ }^{20}$ In accordance with the requirements of International Law as well as of our neutrality laws, it also prohibited "the fitting out and arming of any ship or vessel with intent that such ship or vessel shall be employed in the service of either belligerent," as also the "increasing or augmenting of the force of any ship of war, cruiser, or armed vessel in the service of either of the said belligerents." For the same reasons it prohibited the preparing or setting on foot of any military expedition or enterprise against the territory of either bel-

${ }^{18}$ In respect to the construction, sale and exportation of ships of war, International Law would probably gain in efficiency as well as clearness if these acts were altogether forbidden. It is highly probable that this is now the rule. But this is a point which will be more fully discussed in a subsequent chapter.

"Bernard, The Neutrality of Great Britain, p. 398.

"As has been noted above, these would not, strictly speaking, necessarily be offenses in the eyes of Intcrnational Law. 
ligerent, and it forbade the use of our ports or territorial waters for any military purpose.

The President's Proclamation also directed the enforcement of the two twenty-four-hour rules, viz., the rule requiring that vessels belonging to either belligerent and entering a neutral port during the war be required to leave within twenty-four hours after their arrival, except in case of necessity, and the rule which provides that an interval of at least twenty-four hours must elapse between the departure from a neutral port of vessels belonging to opposing belligerents. These rules are now so generally observed by neutral states that they are in all probability in process of becoming a part of the law or practice of nations, if, indeed, they do not already deserve this description. The same may be said of two other requirements, likewise inserted in the President's Proclamation and now generally observed in the practice of nations, to the effect that ships of war belonging to either belligerent shall only be permitted to take in a supply of coal at any of our ports sufficient to take them to the nearest home port, ${ }^{21}$ and that the same vessel, after having once been furnished with coal, shall not receive another supply at any of our ports within three months, unless she shall in the meantime have entered a port of the government to which she belongs. ${ }^{22}$

${ }^{21}$ The British Proclamation of Neutrality adds, "or to some nearer named neutral destination."

${ }^{22}$ It is perhaps too much to say that these are rules of International Law at the present time, but they are undoubtedly in process of rapidly becoming so. They have been incorporated into many of the recent Neutrality Proclamations, at least in those of the United States and Great Britain.

The rule limiting the stay of a belligerent war-vessel to twenty-four hours, except in case of necessity, also appears, $e$. g., in the recent Neutrality Proclamations of China, Denmark, Norway and Sweden, Italy 
In a subsequent Executive Order, ${ }^{23}$ President Roosevelt warned all officials of the Government, whether civil, naval, or military, not only to observe all obligations of neutrality during the present war between Japan and Russia, but "also to abstain from either action or speech which can legitimately cause irritation to either of the combatants." This proclamation is said to have produced a good effect in Russia and to have somewhat allayed the feelings of irritation of the Russian Government and people against the United States. Although doubtless an act of wisdom and discretion on the part of our President, this additional proclamation was not necessary from the point of view of our international obligations, and it can hardly be said to have been binding upon the majority of those to whom it was addressed.

If the United States and Great Britain can show a remarkably clear and consistent record in the performance of their neutral duties during the Russo-Japanese War, the

and The Netherlands. Denmark and Norway-Sweden also strictly limit the supply of coal in neutral waters. In Norway-Sweden a number of ports and fjords were entirely closed to the entry of belligerent warships. For the various Neutrality Proclamations issued after the outbreak of the Russo-Japanese War, see House Doc. of the 58th Congress, 3rd session (For. Rel.), pp. 14-36, and Revue Générale de Droit Int. Pub., t. XI (1904), Documents, pp. I-I8.

It seems always to be assumed in current discussions that these rules are part and parcel of International Law. Where modern governments as well as the general public are willing to take such advanced ground, it would seem to be unbecoming for publicists to lag too far behind. This is especially true of the rule limiting the supply of coal in neutral ports. In view of the supreme importance of coal under conditions of modern naval warfare, there can scarcely be any question but that a very limited supply only should be furnished to belligerent vessels at neutral ports. But this subject will be discussed more fully in a subsequent chapter. See infra, ch. 7 .

${ }^{23}$ Printed in House Doc., 58th Congress, 3d Session (For. Rel.), 1904, p. 185 . 
same can scarcely be affirmed of Germany and France. The complaints which were directed especially against Germany will be discussed in the next chapter. ${ }^{24}$

${ }^{20}$ For the charges against France, see infra, ch. 7. 


\section{CHAPTER III}

The Construction, Sale, and Exportation by Neutrals of Warships, Submarines, and Other

Vessels INTENded for Belligerent Service

The charges against Germany raise some very difficult and delicate questions which are inseparably connected with a great historical controversy. The most important of these charges are that the German Government failed to prevent (if, indeed, it did not, directly or indirectly, encourage) the sale to Russia of a number of transatlantic steamers belonging to its Auxiliary Navy, and that it permitted the exportation overland of torpedo boats to Russian territory.

Soon after the beginning of the war the charge was freely circulated in the newspapers, and was even made on the floor of the German Reichstag, ${ }^{1}$ that the Russian Government had purchased several vessels (notably the Fürst Bismarck, of the Hamburg-American Line) belonging to a great German transatlantic line, whose vessels are auxiliary cruisers of the German Navy. In reply to the strictures of Herr

${ }^{1}$ By Herr Bebel, the famous leader of the Socialists. See N. Y. Times for April 15, 1904. For other reported sales, see, e. g., London Times (weekly ed.) for April 15 and May 13, and N. Y. Times for May II. It was also reported that Japan had bought eight steamers belonging to the North German Lloyd Co., but this report was officially denied by the Japanese Government. It seems certain, however, that a considerable number of auxiliary cruisers of the German Government belonging to the North German Lloyd and the Hamburg-American Companies were purchased by Russia, equipped in Russian ports, and sent out to prey upon neutral commerce in the summer of 1904 . 
Bebel, who maintained that "such sales accomplish indirectly the reinforcement of the Russian Navy," Chancellor von Bülow is reported to have claimed that, "according to the principles of International Law hitherto prevailing, the sale of the vessels of a private firm to a foreign state was admissible." "At any rate," he declared, "the question is a doubtful one." He admitted that "the principle of neutrality forbids a neutral state from giving direct or indirect support to either belligerent through furnishing ships for war transportation purposes." However, "in the case of the Russian transports, it was not to a state, but to private firms that the vessels were sold. There could not be any question of taking sides against Japan, since she also had full liberty to buy vessels from Germany."'.

It was also charged on the floor of the German Reichstag, ${ }^{3}$ as well as in the newspapers, that the German Government permitted the exportation overland of a number of torpedo boats and destroyers for the use of the Russian Navy. It was charged that, for the purpose of disguising these transactions, "the several parts of the vessels are being exported as half-finished manufactures and put together in Libau, Russia," whither a large number of German workmen had been sent. It was also asserted that these submarine boats were originally built for the German Government, which refused to take them because the terms of the contract ( $i . \mathcal{c}$., the stipulations as to time limit) under which they were built had not been strictly observed.

It appears, however, that Germany was not the only coun-

${ }^{2}$ For reports of these somewhat puzzling utterances, see N. Y. Times and Chicago Tribune for April 15, 1904 .

"By Herr Bernstein, the anti-Bebel Socialistic leader. See, e. g.. N. Y. Times for May 5, and editorials in N. Y. Tribune for May I4 and Hartford Courant for May 5. 
try in which Russian agents were busy in making and soliciting contracts for the purchase or construction of vessels for the use of Russia in the war, but that Japanese agents were similarly active in other countries as well. Germany seems, however, to have been the most flagrant offender in these respects.

It was reported early in June, 1904, ${ }^{4}$ that Russia had ordered five armored cruisers to be built at Trieste, but this report was afterwards contradicted by the Vienna correspondent of the London Times. Russia was also said to have purchased a number of fast cargo vessels in England, with a view to their alteration for use as transports, ${ }^{5}$ and Premier Balfour publicly justified such sales. At a meeting of a section of the London Chamber of Commerce held on August 25, 1904, he said: "There can be no doubt that merchant ships may be sold by neutrals to any government, and that that government may turn these ships into cruisers if they please."

It was also stated that several new battleships had been ordered by Japan in England prior to the beginning of the war, and that these were in process of construction ${ }^{7}$ in April, 1904. Several new ones are said to have been ordered later in the year. ${ }^{8}$ In May, 1904, the Russian and Japanese Governments were reported to be in sharp competition for the purchase of transports in Holland and Belgium, ${ }^{9}$ and repeated and persistent rumors were current to the effect that

'Chicago Tribune, June I, I904.

N. Y. Times, May 28, 1904.

- London Times (weekly ed.) for Sept. 2, I904. Premier Balfour admitted that one of the vessels bought by Russia was a British ship.

'Chicago Record-Herald, April Io, I904.

N. Y. Times, Aug. I3, 1904.

N. Y. Times, May 25, I904. 
agents of both Russia and Japan were busy negotiating for the purchase of cruisers belonging to several South American states, more particularly those of Chile and the Argentine Republic. ${ }^{10}$ It was reported at St. Petersburg on September 20, 1904, that four warships purchased from the Argentine Republic had arrived at Libau, but the sale of Argentine warships was flatly denied by Señor Betbader, the Minister of Marine at Buenos Ayres. ${ }^{11}$ It was also vaguely rumored at one time that Turkey was purchasing ships on Russia's account. ${ }^{12}$

Nor is this all. It seems that both Russian and Japanese agents were at work in the United States. It was reported in May, 1904, that a contract for the construction of four Lake submarine boats destined for service in the Japanese Navy during the war had been awarded the Newport News Shipbuilding Company, of Newport News, Virginia. ${ }^{13}$ In June a submarine torpedo boat, the Protector, was shipped as cargo on board the Norwegian steamer Fortuna, which sailed from New York in June, bound nominally for Cork. ${ }^{14}$ It was generally supposed at the time that the real destination of this vessel was Japan, and a leading Russian news-

${ }^{10}$ See especially H. W. Wilson in the London and the New York Times for May 26, 1904. The Chilian Congress is said to have refused a very high price offered by Japanese or Russian agents for six warships. The St. Petersburg correspondent of the London Telegraph claimed to have learned that an unpublished report from Admiral Witthoeft asserted that the Japanese fleet contained several warships formerly belonging to the Chilian navy. But these vessels may have been purchased before the outbreak of the war, as were several cruisers belonging to the Argentine Republic. Such sales are perfectly legal.

${ }^{11}$ See N. Y. Times, Sept. 2I and 22, 1904.

${ }^{12}$ N. Y. Times, June 13 , 1904.

${ }^{18}$ N. Y. Times, May II, 1904.

${ }^{14}$ See N. Y. Sun for June 10 and 14, 1904. 
paper (the Novoe-Vremya) called upon the United States Government to explain why she had been allowed to leave the territory of the United States $;^{15}$ but the Protector finally turned up in Kronstadt, Russia, early in July. ${ }^{16}$

Later, in July, 1904, another submarine boat, the Fulton, was reported to have arrived at Kronstadt and to be undergoing tests in the Neva. The Fulton had, it appears, been purchased from the Holland Construction Company and had been shipped from Newport in the latter part of June on the deck of the Menantic. ${ }^{17}$ Acting Secretary of State Loomis is reported to have made the following statement in regard to this matter: "This Government will take no action. Under a ruling made some years ago by the State Department, a smaller vessel shipped on a larger vessel, as in the case of the Fulton, is contraband of war. Therefore, any person who ships or buys contraband does so at the risk of capture by either belligerent. Japan, in other words, could have seized this Fulton as contraband of war. Japan has made no protest to this Government, so far as I know. The general principle is that the owner of the contraband must take all the risks. If the Fulton had been rigged out here and a crew put aboard of her, it would have been an entirely different question. The United States would not have permitted it, as a neutral country." 18

After the shipment of the Protector and the Fulton to Russia, there were frequent and persistent rumors of the sale, construction, or exportation of torpedo craft in or from the United States to or for both belligerents. One report,

${ }^{15}$ Chicago Tribune, June $12,1904$.

${ }^{16}$ N. Y. Times, July 8, 1904.

${ }^{17}$ N. Y. American, July 16, 1904.

${ }^{38}$ N. Y. American, July I6, 1904. 
e. g., spoke of a Russian order for thirty submarines of the Protector type, and another of an order from Japan of fifty such boats of the Holland type. ${ }^{19}$ Similar orders were said to have been placed in Germany and Austria-Hungary.

The failure of the British Admiralty Office in October, 1904, to prevent the delivery of the torpedo boat destroyer Caroline into the hands of a Russian agent aroused some severe criticism in England, and was made the subject of editorial comment in the London Times. ${ }^{20}$ But it was alleged by her builders, Messrs. Yarrow \& Co., that the Caroline was bought from them as a yacht and fitted up as such. They claimed that there was no armament of any kind on board when the vessel left their yard on October 6, and that very considerable alterations would have been necessary in order to fit her as a torpedo boat. ${ }^{21}$ Although the sale of the vessel was reported to the British Admiralty the day after it was made, we are not aware that any evidence was produced which would tend to show that the British Government had knowledge of the purpose for which this yacht was to have been used.

These reports, which are drawn from the newspapers, may be somewhat wanting in accuracy and authenticity, but, assuming that they are substantially true, they may serve as the background for a discussion of the following questions: whether the construction, sale, and exportation by neutral

${ }^{10}$ New York dispatch to the London Times for October 13, 1904.

${ }^{20} \mathrm{~N}$. Y. Times and London Times for December 3, 1904. It appears, however, that the British Foreign Office had stopped the sale of a similar vessel to a Paris firm two months previously on the ground that it might fall into the hands of Russia or Japan.

${ }^{21}$ For the alleged facts in this case, see London Times (weekly ed.) for December 2, 1904, p. 772. For a summary of the letter from Messrs. Yarrow \& Co., see London Times (weekly ed.) for December 9, 1904, p. 795. 
states and individuals of warships, torpedo craft, and other vessels adapted to warlike use and intended for belligerent service, constitute a violation of neutral obligations; and whether a neutral state can be held responsible in such cases.

It, of course, goes without saying that the direct sale of a war vessel by a neutral state to either belligerent would be a gross breach of neutrality, for which ample redress or reparation ought at once to be demanded, and, if necessary, exacted by the injured state. ${ }^{22}$

Since the settlement of the famous "Alabama Case" by the Treaty of Washington in 1871 and the Geneva Award of 1872 , there can scarcely be room for doubt that a neutral state may be held responsible in damages if its Government knowingly permits the fitting out, arming or equipping ${ }^{23}$ within its jurisdiction, or the departure from its territory of any vessel intended for belligerent service. The First Rule of the Treaty of Washington declares that "a neutral state is bound to use due diligence to prevent the fitting out, arming, or equipping within its jurisdiction of any vessel which it has reasonable ground to believe is intended to cruise or to carry on war against a Power with which it is at peace, and also like diligence to prevent the departure from its jurisdiction of any vessel intended to cruise or carry on war

n Such sales by Chile to both belligerents were reported during the war between China and Japan in 1895. See an article by Professor Holland in Fortnightly Revieze for June, 1895, Vol. 63, p. 913. The best modern usage not only forbids this practice, but scrutinizes very carefully all sales of vessels made by a state during a war. For examples, see Lawrence, $W$ ar and Neutrality, pp. 177 ff. Modern usage does not, however, forbid the sale of such vessels prior to the outbreak of war.

${ }^{23}$ The arming and equipping of such a vessel, as also the augmentation of the force of a war vessel in a neutral port, had been prohibited by International Law, as well as by the British and American Neultrality Acts, for many years. 
as above, such vessel having been specially adapted, in whole or in part, within such jurisdiction to warlike use."24

Although the principles incorporated into this rule have not won the unreserved approval of all English publicists, ${ }^{25}$ and have not been formally accepted by the Powers, ${ }^{26}$ they

* For the Three Rules of the Treaty of Washington, see, e. g., Wharton's Dig. III, p. 630. It is now also generally recognized that third powers owe similar obligations toward established or recognized governments which are engaged in a civil war, or in a struggle with insurrectionists or revolutionists. See the rules adopted by the Institute of International Law in the Annuaire for 1900 .

${ }^{25}$ E. g., Hall ( $\$ 225$ and notes) and Lawrence, Principles ( $\$ \S 262$ and 263). Hall, although he insists that this is not the law, was of the opinion that such a usage is in course of growth. He seems, moreover, to have looked upon such a rule or usage as healthy and desirable, if it be not based upon the doctrine of intent, in place of which he suggests the alternative principle of the character of the vessel. Lawrence thinks "the question is still far from settlement." He says that "the old principles have been thoroughly discredited and the maritime Powers have come to no agreement upon new ones." That the First Rule of the Treaty of Washington is probably a rule of International Law is admitted by Walker (Manual, $\S 65$ ), "provided a fair interpretation be accorded to the phrase "due diligence'." "The general consensus of opinions of publicists, with some dissent in England, is that they (the Three Rules of the Treaty of Washington) are a correct statement of existing International Law." Foster, American Diplomacy, p. 429.

${ }^{28}$ The United States and Great Britain agreed, according to the terms of the Treaty of Washington, to abide by these rules in their future relations with each other, and to invite other maritime Powers to accede to them, but such an invitation has never been issued. The failure to invite or secure the adhesion of the maritime Powers to these rules does not, however, destroy their validity or impair the value and importance of the decision of the Geneva Board of Arbitration as a precedent. Additions to International Law are usually the result of a natural growth rather than of formal legislation, and if all such additions had to await the formal sanction of the Powers, there would be, comparatively speaking, little growth or progress. If the decisions of national prize courts constitute an important source of International Law, how much greater should be the value as precedents of the decisions of International Courts of Arbitration.

Although the value and importance of the decision of the Geneva Board of Arbitration as a precedent can scarcely be called into ques- 
may now be regarded as forming an integral and important part of the correct practice of International Law. They have, generally speaking, found favor in the eyes of continental jurists, ${ }^{27}$ and they were adopted, although in somewhat altered language, by the Institute of International Law in $1875 .{ }^{28}$ They have long since been incorporated in the Neutrality and Foreign Enlistment Acts of the United States and Great Britain, ${ }^{29}$ and the British Foreign Enlistment Act of 1870 , which has been pronounced by a leading

tion, there is still some difference of opinion in regard to the correct meaning of the phrase "due diligence"; there are serious objections to the American doctrine of intent; and all of the decisions of the Geneva arbitrators (or rather the reasoning on which some of these decisions were based) have not been fully accepted on all sides.

${ }^{2 \pi}$ See, e. g., Calvo in Revue de Droit International, VI, pp. $453 \mathrm{ff}$; Bluntschli in the same review, II, pp. $452 \mathrm{ff}$; Calvo, Le Droit Int., IV, \& 2,623; Bluntschli, Droit International Codifié, §\& 763, 765, and notes; Fiore (Antoine's trans.), III, \& I,555; Rivier, II, \& 68, pp. $405 \mathrm{ff}$; and Kleen, Les Lois et Usages de la Neutralité, I, p. 315.

${ }^{2}$ Tableau Générale de l'Institut, pp. 161-63. Cf. Annuaire for 1877, p. 139 .

The United States Neutrality Acts of 1794 and 1818 and the British Foreign Enlistment Acts of 1819 and 1870. The British Act of 1819, like the United States Acts of 1794 and 1818, prohibited the fitting out, as well as the arming, of any vessel with intent, etc.; but the administrative and preventive powers (viz., those requiring bond and authorizing detention for probable cause) of the tenth and eleventh sections of the United States Act of 1818 were omitted in the British Act of 1819. The evidence required in order to convict under the British Act of $18 \mathrm{ig}$ had to be sufficient to satisfy a jury of the probable violation of the provisions of the statute, and such evidence was, of course, extremely difficult to obtain. The defects in the British Act of 1819 were probably due to lack of effective procedure or a want of proper administrative machinery, rather than to any lack of good intention on the part of the legislature. To those administrative defects there was added a certain inertness or indifference in the execution of the law, if not of positive sympathy with the Southern Confederacy, on the part of the governing classes of England, which lamed the energies of the British Government and caused its failure to strictly observe its obligations of neutrality during our Civil War. 
authority to be "perhaps the best and fairest expression of the modern rule anywhere to be found in public law," ${ }^{30}$ goes at least one step farther than our own Neutrality Act and the Treaty of Washington. It prohibits not only the commissioning, equipping, and dispatching, but also the building or construction of "any ship with intent or knowledge or having reasonable cause to believe that the same shall or will be employed in the military or naval service of any foreign state at war with any friendly state." ${ }^{\prime 1}$

True it is that a long line of American jurists and statesmen have held, in the language of Judge Story," that "there is nothing in our laws, or in the law of nations, that forbids our citizens from sending armed vessels, as well as munitions of war, to foreign ports for sale. It is a commercial adventure which no nation is bound to prohibit, and which only exposes the persons engaged in it to the penalty of confiscation." The American view that vessels built or sent out solely with the animus vendendi are mere contraband of

${ }^{* 0}$ Snow, Cases, p. 438. Cf. Scott's edition, p. 720.

s1 8 of the British Foreign Enlistment Act of 1870 . See 33 and 34 Vict. 90. For a convenient abridgment of the British and American Neutrality Acts, see Scott's edition of Snow's Cases, pp. 692-95.

${ }^{32}$ In the Santissima Trinidad, U. S. Supreme Court, 1827,7 Wheat. 283. For a digest of leading American cases involving a breach of our neutrality laws, see Dana's Wheaton, note 215, pp. 543-557. For opinions of American statesmen and judges, see Wharton's Dig. III, $\$ \$ 393$ and 396. See especially the opinions of Secretary Clay and those of Judges Betts and Nelson in the case of the Meteor. Secretary Clay was of the opinion that "if the neutral show no partiality; if he is as ready to sell to one belligerent as the other; and if he take, himself, no part in the war, he can not be justly accused of any violation of his neutral obligations." But then Mr. Clay does not seem to have been absolutely sure that it was a violation of neutrality for the head of a state to sell, to a belligerent, ships of war completely equipped and armed for battle. Mr. Clay, Secretary of State, to Mr. Tacon, Wharton's Dig. III, p. 52I. 
war, but that vessels fitted out or dispatched with an animus belligerandi constitute in effect a proximate hostile expedition which it is the duty of the neutral government to prevent, if possible, by the use of a reasonable diligence, is one which was long insisted upon, especially by American statesmen, judges, and publicists, and this doctrine still holds a place in some important works on International Law. ${ }^{\mathbf{3 3}}$

But this view can scarcely be longer maintained in the face of the First Rule of the Treaty of Washington, and of the increasingly sensitive and ever-growing sense of neutral obligations on the part of modern nations. As one of our leading American authorities, Dr. Freeman Snow, has well said: "In considering this question, it should be remembered that, by the introduction of steam as the motive power of ships, and of iron and steel as the material of their construction, the conditions of maritime warfare have been very radically changed. What might have been a reasonable rule as applied in the time of sailing ships might now, in the age of swift ironclads, be intolerably oppressive. In the cases of the Santissima Trinidad, U. S. v. Quincy, and the Meteor, the courts were dealing with small sailing vessels, which had been converted into privateers, the possession of which by one or the other belligerent made very little difference in the general result of the struggle; whereas, the possession of an ironclad ship might well turn the scale one way or the other, as indeed it did in the war between Chile and Peru, in I880188I. This great power of inflicting injury upon one of the belligerents, it is fair to say, ought not to be permitted to

*3 The best and most authoritative statement of this view is by Dana. See Dana's Wheaton, note 215, p. 563. A recent defense of this view may be found in Taylor, Public International Law, Pt. V, ch. 2. 
neutral citizens, and the neutral nation is alone in a position to restrain them.

"In view of these facts, it is believed that the doctrine set up by the United States Neutrality Act and by the Federal Courts, that the 'intent' of the owner or shipbuilder is the criterion by which his guilt or innocence is to be judged, is wholly inadequate; it would not for a moment stand the test of the rule of 'due diligence' as applied by the Geneva tribunal." ${ }^{4}$

The American doctrine of intent has also been justly and severely criticised by a number of English writers. Walker ${ }^{35}$ points out that it "leaves open to fraud a wide and open door." He continues: "Who may know the intent of a crafty and secret mind? A thousand tricks and devices may be employed to disarm suspicion. An unarmed vessel may be dispatched from a neutral port, arms and men from another, and the intent with which these elements were prepared and gathered together may only become apparent on their combination at some spot far beyond the bounds of the neutral jurisdiction." Lawrence ${ }^{36}$ says : "Nothing is more difficult to prove than intentions. They have frequently to be inferred from actions of an ambiguous character. Moreover, the two intents-that of selling and that of making war-may co-exist in the same mind." Bernard ${ }^{37}$ declares: "In international wrongs . . . the intent is not the thing chiefly or mainly regarded; and in international wrongs of this particular class the only intent and the only inadvertance which are really material are, first, that hostility in the per-

${ }^{34}$ Snow's Cases, note on "The Three Rules of the Treaty of Washington" on pp. 437-38. Cf. Scott's Cases, p. 720.

${ }^{25}$ Science of International Law, p. 500.

${ }^{33}$ Principles, p. 548.

${ }^{3}$ Neutrality of Great Britain during the American Civil War, p. 389. 
sons who constitute or direct the expedition which makes it noxious instead of harmless; and secondly, that connivance or negligence on the part of the neutral government which makes the nation responsible for the noxious enterprise." Dana, ${ }^{38}$ the leading champion of the doctrine of intent, admits that "the act is open to great suspicions and abuse, and the line may often be scarcely traceable." Hall ${ }^{39}$ remarks upon this passage: "It is eminently inadvisable in matters which may lead to international controversy to adopt as the test of the character of an action anything so indeterminate as to be 'often scarcely traceable.' No intent other than that which is inferred from acts of a broadly marked character can be safely so used."

The complexity of this doctrine of intent and the fine distinctions to which it has led in practice may be seen by consulting the case of the $U$.S. v. Quincy (Supreme Court of the U. S., 1832, 6 Peters 445). In this case a distinction was made between a fixed and present intent on the one hand and a conditional or contingent intent on the other. It was held that if the intent was to send the vessel in question to the West Indies in search of funds with which to complete her armament, with no present or fixed intention of preying upon the commerce of a friendly state, but with a mere conditional or contingent intent or wish to fit her out after her arrival there, it was not an illegal transaction.

On the other hand, the older English doctrine to the effect that a ship adapted for belligerent use is a mere article of contraband unless she leaves the neutral port in a condition capable of committing hostilities the moment she enters upon her voyage was wholly unsatisfactory and absurdly

Note 215 to Wheaton.

Treatise ( $3 \mathrm{~d}$ ed.), p. 6rg, note. Cf. Lawrence, op. cit., p. 548. 
inadequate. This view presupposed innocence on the part of the owner or shipbuilder unless the vessel was at least partly armed and equipped in the neutral port. This was in substance the doctrine laid down in 1863 in the case of the Alexandria (Att. Gen. v. Sillem, 2 Hurlstone and Coltman, Excheq. Rep. 43I) by Chief Baron Pollock and Baron Bramwell. ${ }^{ \pm 0}$

There has also been considerable controversy as to the true meaning of the phrase "due diligence." The American contention at Geneva was that it meant diligence "commensurate with the emergency or with the magnitude of the results of negligence." The British case set forth that "due diligence on the part of the sovereign government signifies that measure of care which the government is under an obligation to use for a given purpose. This measure, when it has not been defined by international usage or agreement, is to be deduced from the nature of the obligation itself, and from the considerations of justice, equity, and general expediency on which the law of nations is founded." A more vague and unsatisfactory definition than this can scarcely be imagined. The Geneva arbitrators adopted in substance the American definition, although couched in somewhat different language. They held that due diligence should be "in exact proportion to the risks to which either of the belligerents may be exposed from a failure to fulfill the obligations of neutrality on their part."

This definition has been criticised ${ }^{41}$ on the ground that it accepts the principle of a "changing standard" of neutral obligations, and "imposes different degrees of responsibility

${ }^{*}$ On the Alexandra, see especially Bernard, Neutrality, pp. 353-54 and note, and Walker, op. cit., p. 499.

${ }^{41}$ E. g., by Lawrence, Principles, pp. 538-540. 
upon different neutrals in the same war, and thus destroys that impartiality which is the essence of neutral duty." But it is doubtful whether any definition which has been or which could be framed would be wholly free from difficulty or to which serious objection might not be made. Lawrence suggests that "the kind and amount of diligence which a strong and careful government would use to put down smuggling ought to be used by neutral states to fulfill the obligations of their neutrality." This suggestion would certainly seem to furnish a good practical working rule or standard of neutral obligations, but it may be doubted whether even this rule would give us the precise and absolute standard which Lawrence seems to be in search of. Certainly some account should also be taken of the "emergency" and of the "risks" or "magnitude of the results of negligence." For example, the same degree or amount of diligence would scarcely be required in the case of a small submarine boat as in the case of a large warship or of a number of these. ${ }^{42}$

${ }^{42}$ For a severe criticism of the definition of "due diligence" adopted by a majority of the arbitrators at Geneva, see an article by Rolin Jacquemyns in the Revue de Droit Int., VI, pp. 567 ff. For citations from the opinions of the Geneva arbitrators, see Wharton's Dig. III 4022 and Moore's History of Arbitration, IV, ch. 68. For a full and complete history of the "Alabama Case" and the Geneva Award, see $U$. S. Diplomatic Correspondence for the years 1863-1871; Papers Relating to the Treaty of Washington; Case of Great Britain with Appendix; Claims of the U. S.; Case of the U. S., etc. For a good abridgement of the proceedings of the Geneva Board, see Moore on Arbitration, I, ch. I4. For a good short history of the "Alabama Case," see Walker, Science of International Law, pp. 458-502, and Kleen, Les Lois et Usages de la Neutralité, I, pp. 285-316. For an excellent summary of the controversy from the British point of view, see Bernard's Historical Account of the Neutrality of Great Britain during the American Civil War. For a summary of the controversy from the American point of view, see Cushing's Treaty of Washington. See also Balch, The Alabama Arbitration, 1900. 
In view of the unsatisfactory and inadequate character of the older body of doctrine, would it not be well to take a step or two even beyond the First Rule of the Treaty of Washington and broadly assert that a neutral state is bound to use due diligence ( $i$. e., a kind and degree of diligence reasonably sufficient under the circumstances) not only to prevent the fitting out, arming or equipping within its jurisdiction and departure from its territory of any vessel intended for the use of either belligerent, but also the construction, sale and exportation of any warship whatsoever for or to any other than a bona fide neutral purchaser? Nay, would it not be well to go still farther and insist that a neutral state is bound to use due diligence to prevent the construction for, or sale to, a belligerent purchaser, or the exportation to a belligerent destination, ${ }^{43}$ of any vessel which is adapted or readily convertible to belligerent use ? $^{44}$

It will be said that this is an invasion of the commercial rights of neutral individuals who depend upon shipbuilding for a livelihood or for profit, and that it imposes onerous and difficult burdens upon neutral states. Moreover, "if a distinction is to be made between vessels serviceable for warlike use and other vessels, where, it may be asked, are we to fix the line ?"45 It is very doubtful whether our shipbuilding

${ }^{43}$ In case the destination were nominally neutral, but really belligerent, the doctrine of "continuous voyage" might be made to apply.

"Bonfils ( $\$ 1467$ ) thinks that a neutral state should "forbid to its subjects the sale of all armed war ships and oppose their departure by all means in its power." These questions are discussed at length by Kleen, op. cit., $\S 83$, pp. 323-3I (especially p. 329) and $\S 85$, pp. 335 339. Kleen lays down the following rule $(\$ 85$, p. 335$)$ : "A neutral state should neither directly nor indirectly, send, remit, or deliver, to a belligerent, war ships or vessels that are notoriously adapted to warlike use or intended for belligerent service, nor should it allow its subjects to do so."

${ }^{45}$ Bernard, op cit., p. 395. 
interests $^{46}$ would greatly suffer by an adoption of these principles; but, even supposing that this were the case, have communities or nations ever hesitated to sacrifice the vested rights or commercial interests of certain individuals, or even classes, to the general welfare of society as a whole? If they have not hesitated to exact these sacrifices in the interest of particular communities or nations, how much less hesitation should there be when the welfare of humanity at large or the collective interest of civilization are at stake!

But, it may be asked, should we not go still farther, and, as has frequently been suggested, prohibit all trade in arms and ammunition or implements of warfare between belligerents and neutrals? To this piece of apparently unanswerable logic we may reply that to compel neutral states to assume such responsibilities would burden them to such an extent that in some cases they might prefer the status of belligerency to that of neutrality. In framing rules of International Law we should be careful never to exceed the limits of the practical, and we should avoid the mistake into which our legislatures so often fall of framing rules which are difficult or impossible to enforce.

${ }^{46}$ Even under the interpretation given to our present law, it is rather difficult to imagine a case where such a vessel might so be disposed of (if sold to a belligerent purchaser or dispatched to a belligerent destination) as to free the neutral trader or builder from all taint of suspicion of being engaged in an illegal venture or an unlawful transaction (see $e$. g., the cases of the Meteor and the $U$. S. v. Quincy, cited above). In practice it is very difficult to distinguish between a belligerent and a commercial intent. There is no attempt at such a distinction in the case of contraband of war where the character of the articles and the belligerent destination furnish the justification of capture. The main difference between the two cases would be that in the case of contraband the right of capture belongs to the belligerent; in that of vessels adapted to warlike use and intended for a belligerent destination, the duty of prevention would rest on the neutral, as it indeed already does to a very considerable extent. 
Would it be impossible or difficult to enforce the prohibition of the sale to, or construction for, a belligerent purchaser of all vessels adapted or readily convertible to warlike use, or to prevent the exportation of such vessels to a belligerent destination? Some at least of the nations have already burdened themselves with considerable responsibility in this direction. According to our own neutrality laws, such a vessel might indeed be built and sold as an article of commerce, but it must not be permitted to depart from any of our ports if intended for belligerent use. In England, since the enactment of the British Foreign Enlistment Act of I870, such a vessel could not lawfully be built or contracted for. According to the older statutes, the Alabama might have been built and sold as an article of commerce, if she had not been directly intended for the service of the Confederacy. But, as an able writer has well said: "It is clear that proof of an intention hostile in fact, or constructively hostile, in the builder of a ship or his workmen, or in the maker or purveyor of guns or ammunition, has really little or nothing to do with the question whether the belligerent nation has sustained injury from the neutral. To the United States it was of no consequence at all what were the intentions of Laird or Miller, or their riggers or ship carpenters, or whether these persons, or any of them, were animated by partiality to the Confederates, or were merely working, in the exercise of their respective trades, for what they could get. What was of consequence to the United States was the intention with which the vessels were dispatched from England by those who had at that time the real control of them. . . Nor did it matter to the United States whether the vessels were purchased ready-made or were built to order. . . . In a word, as between nations, the intent which 
impresses on an armed ship, dispatched from a neutral port, the character of a hostile expedition is the intent which governs the dispatch of the ship, not the intent which presided over its preparation." ${ }^{47}$

As to the difficulty of distinguishing between vessels serviceable for warlike use and other vessels, it must be admitted that this is a real and serious difficulty; but it is one which might, we think, be overcome by the exercise of proper care and exertion on the part of the neutral government. ${ }^{48}$

"Bernard, op. cit., pp. I96-97. This argument was used by Bernard against the American claims, but it merely proves the inconsistency or inadequacy of the American doctrine of intent. This doctrine is now mainly open to criticism because it does not go far enough. It is too narrow and restricted in its scope. By condemning the commercial as well as the belligerent intent, much of the difficulty and doubt to which it has given rise would vanish. On the inadequacy of the doctrine of belligerent as distinguished from commercial intent, see also Kleen, op. cit., pp. $325,33 \mathrm{I}-35$, and 338 .

The real question is as to whether the vessel is likely to prove useful to, or fall into, the hands of one of the belligerents. This must be prevented, if possible, i. e., due diligence must be used by the neutral state to prevent it. Due diligence, of course, implies knowledge.

4 $T$ his is a question for experts. Hall (p. 620) says: "Experts are perfectly able to distinguish vessels built primarily for warlike use: there would therefore be little practical difficulty in preventing their exit from neutral ports, and there is no reason for relieving a neutral government from a duty which it can easily perform. But it is otherwise with many vessels primarily fitted for commerce." Hall calls special attention to the fact that "mail steamers of large size are fitted by their strength and built to receive, without much special adaptation, one or two guns of sufficient calibre to render the ships carrying them dangerous cruisers against merchantmen." He remarks that these vessels "melt insensibly into other types," and he thinks that "it would be impossible to lay down a rule under which they could be prevented from being sold to a belligerent and transformed into constituent parts of an expedition immediately outside neutral waters without paralyzing the whole ship-building and ship-selling trade of the neutral country." Part of this argument has been dealt with above. Hall certainly exaggerates the injury to ship-builders. We would not presume to say to what extent experts can distinguish between the different classes of 
There can be no doubt that the German Government was guilty of a violation of neutrality in permitting the sale and delivery of the transatlantic steamers of the great German steamship companies to agents of the Russian Government. The sale of merchant vessels by neutral individuals to belligerents has generally been upheld in spite of the adaptability of many of these vessels to warlike purposes, ${ }^{48}$ although the arming and equipping, as well as the augmentation of the force of such vessels after having been armed and equipped in a neutral port, have generally been deemed unlawful. The fact, however, that these vessels were auxiliary cruisers of the German Navy puts a different face on the matter. In view of the close and intimate relations which subsist between these companies and the German Government, the sale and exportation of such vessels would seem to be impossible without the consent or connivance of that Government; and it can hardly be contended that such consent or connivance could be given without a serious breach of neutral obligation.

In any case, the reported contention of Chancellor von Bülow to the effect that the sale of the vessels of a private firm to a foreign state or to a private firm is admissible, can not be maintained if it be meant that the neutral government is free from responsibility in all such cases, as $e . g$. , in the case of warships. It has been suggested that Germany

vessels. In order to secure a proper enforcement of the law, guarantees or bonds might be exacted from ship-builders and ship-traders, such as are required by the terms of our own Neutrality Act. The burden of proof should be thrown upon the ship-builder, as is done by the British Act of 1870 . $\mathrm{He}$ is liable if he has "reasonable cause to believe, etc."

to See c.g., the opinion of Secretary Clay to Mr. Rivas Salmon in 1827, Wharton's Dig. III, p. 520. This is not, however, in accordance with the newer and, as we believe, the sounder doctrine advocated above. 
would not have been guilty of any breach of neutrality if she had simply played the part of an "honest broker,"50 and sold ships of all kinds impartially to both belligerents; but this notion is based upon a wholly erroneous conception of the real nature and scope of neutrality. "Neutrality does not consist in the mere impartial treatment of opposing belligerents, but in the entire abstinence from any assistance of either party in his warfare," and "a neutral government is bound not only to abstain from affording any direct addition to the combatant force of either belligerent, but to exercise a reasonable diligence in compelling the like conduct on the part of all persons within its jurisdiction." ${ }^{21}$ Total abstention-not mere impartiality-is in such matters the real extent of neutral obligation.

Modern usage seems also to permit the sale of submarine boats or torpedo craft as merchandise, although it is difficult to justify or defend such usage on principle. Our own Government, following a precedent which was set by Secretary Evarts in $1879,{ }^{52}$ seems to class these boats with contraband of war, at least if shipped in sections, rather than as warships, and consequently declines to forbid their sale or prevent their shipment from American ports. Other governments appear to take the same or a similar view of their obligations in such cases.

The fact, however, that these vessels are not armed or furnished with crews; that they are shipped in sections and

${ }^{\circ}$ See editorial in N. Y. Tribune for May II, 1904, and the opinion of Chancellor von Bülow, cited above. This seems also to have been the opinion of Secretary Clay. See Wharton's Dig. III, p. 520.

${ }^{32}$ Walker, The Science of International Law, pp. 374 and 388 . Attention should be called to the fact that there are certain kinds of indirect aid to belligerents, as, $e$. g., trade in contraband, which are not forbidden to neutral individuals.

62 Wharton's Dig. III, § 391, p. 515. 
are not fully completed on neutral territory, ought not to free neutral governments from responsibility (provided they have knowledge) in this matter, any more than the fact that the Alabama received her armament in Portuguese waters absolved the British Government during the Civil War. Besides, both the First and the Second Rules of the Treaty of Washington seem expressly to cover such cases. Indeed, any kind of a modern war vessel intended for belligerent service is a weapon with such tremendous possibilities of destruction that it approximates a military expedition; and the exportation of such a vessel, either as a whole or in sections, for the use of a belligerent, from a neutral port amounts in effect to the use of neutral territory as a base of military operations, or to the origination of a proximate act of war on neutral soil-acts which are clearly forbidden by International Law. ${ }^{53}$

In the case of the submarine boat Protector, which was shipped as cargo on board the Norwegian steamer Fortuna, and which cleared from New York early in June, 1904, the Government of the United States could in no wise be held responsible whatever her destination, although the owners or builders might, possibly, under certain circumstances, have been indicted under our' neutrality laws. ${ }^{54}$ As Mr. Cass, Secretary of State, said in 1860: "A Government is responsible only for the faithful discharge of its international duties, but not for the consequences of illegal enterprises, of which it had no knowledge, or which the want of proof or

ss "No proximate acts of war are in any manner to originate on neutral ground." Sir W. Scott in the Twee Gebroeders, 3 C. Rob. 164.

"These remarks may also be applied to the case of the Fulton. See above, p. 95 . 
other circumstances rendered it unable to prevent." "The case of this submarine was distinctly one in which our Government neither actually had knowledge nor was 'charged' with it. . . . To make sure that no submarines were building in the United States, we should have to maintain a constant inspection of every shipyard and boatyard in the country, which is, of course, out of the question." ${ }^{50}$

It is one of the duties of the diplomatic representatives of the belligerent states in neutral countries to call the attention of such and similar violations of neutrality on the part of neutral individuals to neutral governments. If the Russian or the Japanese representative at Washington had called the attention of our Government ${ }^{57}$ to the fact that a submarine, supposed to be intended for use against his country, was building, our effective responsibility would then have begun. This would have made the case parallel to that of the Alabama. In that case, the Geneva tribunal found from all the facts that the "British Government failed to use due diligence in the performance of its neutral obligations, and especially that it omitted, notwithstanding the warnings and official representations made by the diplomatic agents of the United States, to take in due time effective measures of prevention." Under such circumstances there might possibly have been material for another Alabama case, at least if other conditions had been present, "such as proof that it

${ }^{60}$ Mr. Cass, Secretary of State, to Mr. Molina, 1860. See Wharton's Dig. III, p. 603.

See an excellent editorial on this subject in the N. Y. Times for June 13, I904.

${ }^{57}$ The failure of the representatives of both Russia and Japan to call the attention of neutral governments to these matters is probably due to the fact that both belligerents hoped to profit by such sales or shipments. 
really was a submarine, and proof that it really did some damage to one of the belligerents." 58

${ }^{50}$ From the editorial cited above. Proof of actual injury, as well as actual knowledge and lack of due diligence, would probably have to be furnished by the injured belligerent in order to justify a claim for damages, although the duties of a neutral government would begin long before that point had been reached; but evidence of hostile intention would, under certain circumstances, justify a prosecution under our neutrality laws. 


\section{CHAPTER IV}

War Correspondents, Wireless Telegraphy, and SubMARINE MINES

The Russo-Japanese War has given rise to several interesting and important questions bearing upon the rights and privileges of neutrals in warfare which are wholly new and unprecedented in the history of International Law. In dealing with these questions it may be well to call attention to the fact that a discussion of such topics must necessarily be more or less tentative in its nature, inasmuch as we can not appeal, in support of our views, to the authority of eminent publicists or jurists or to the force of precedents in international practice. In the absence of such guides we must fall back upon the general or fundamental principles of our science or seek for analogous cases in the history of International Law.

The first of these questions relates to the rights of war correspondents and the use of wireless telegraphy in neutral waters and on the high seas.

The head of our State Department must have been considerably surprised to receive the following note from Count Cassini, the Russian ambassador at Washington, on April I5, I904:

"I am instructed by my Government, in order that there may be no misunderstanding, to inform your Excellency that the Lieutenant of his Imperial Majesty in the Far East ${ }^{1}$ has just made the following declaration: In case neutral vessels, having on board correspondents who may communicate news to

${ }^{2}$ Admiral Alexieff. 
the enemy by means of improved apparatus not yet provided for by existing conventions, should be arrested off Kwan-tung, or within the zone of operations of the Russian fleet, such correspondents shall be regarded as spies, and the vessels provided with such apparatus shall be seized as lawful prizes." 2

It is believed that a similar, if not identical, note was communicated to the other Powers, ${ }^{3}$ which was thus in the nature of a general notification to the whole world. After a careful consideration of this announcement by the Russian Government that it proposed to treat as spies any newspaper correspondents falling into its hands who might be engaged

${ }^{2}$ For the text of this note, see the London Times (weekly ed.) for April 22, 1904, and House Doc. of 58th Congress, 2nd session (For. Rel., 1904), p. 729. Cf. N. Y. Times for April 16, 1904. This declaration on the part of the Russian Government is somewhat analagous to Prince Bismarck's threat, during the Franco-Prussian war, to treat those crossing the German lines in balloons as spies. This action of Bismarck has generally been condemned by publicists. The Second Hague Convention (Art. 29) expressly declares that "individuals sent in balloons to deliver dispatches, and generally to maintain communication between the various parts of an army or a territory" are not spies. For Bismarck's declaration, see Guelle, Précis, I, p. 136.

${ }^{3}$ This is true, at least in the case of the British Government. The British note does not seem to have been given to the Press, but on April 22 Earl Percy, Under-Secretary of State for Foreign Affairs, gave an account of Admiral Alexieff's order in the House of Commons which differed from the American version in a very important respect. He spoke of "correspondents, who are communicating information to the enemy," instead of "who may communicate, etc." "There is," as Lawrence (War and Neutrality in the Far East, and ed., p. 85) says in commenting upon this apparent discrepancy, "all the difference in the world between being in a position to do an act and actually doing it." In the latter case, $i$. $e$., if the war correspondent on board the Haimun had actually communicated news to the Japanese, he would have been guilty of having performed an unneutral service for which he would have rendered himself liable for the loss of his ship and apparatus, although even in this case, he would not have been subject to the treatment of a spy. We have accepted the American version and assumed throughout our discussion that there was no question of unneutral service involved. 
in the collection or transmission of news on the high seas by means of wireless telegraphy, our Government appears to have wisely decided to defer action or formal protest until a case of violation of neutral or American rights had actually arisen. ${ }^{4}$

The Russian note to the Powers was provoked by the presence in the Yellow Sea and adjacent waters of a British war correspondent equipped with a De Forest wireless telegraph apparatus ${ }^{5}$ on board the Chinese dispatch boat Haimun. This vessel, which was in the joint service of the London Times and the New York Times, and which flew the British flag, had been cruising about the Gulf of Pe-chi-li and adjacent waters as near to Port Arthur as practicable, and was sending its dispatches by means of wireless telegraphy to a neutral station at the British port of Wei-haiwei, whence they were transmitted to London and thence to New York. The Times' correspondent declared that his messages, being in cipher, could not be recorded either by Russian or Japanese instruments, that they all went to a neutral cable office, that he had never been in Russian waters, and that all of his dispatches had been sent either in neutral waters or on the high seas."

"The Russian Foreign Office was notified, however, that "the United States Government does not waive any right it may have in International Law should any American citizen be arrested or any American vessel be seized." Lord Lansdowne addressed a note to the Russian ambassador in London embodying a reservation similar to that contained in the reply of the United States. (House Doc. of 58 th Congress, 3rd session, Foreign Rel. 1904, pp. 332-33, and p. 729.) Russia appears to have given assurances to the British and American Governments that she did not contemplate any immediate execution of her threat. Lord Lansdowne is reported to have expressed the opinion that the attitude of Russia was "unjustifiable and altogether absurd." See N. Y. Times for April 22, 1904.

- Several of the operators are said to have been Americans.

- See his letter in the N. Y. Times for April 19, 1904. It is worth 
War is now regarded as an abnormal or exceptional relation between states, and the presumption, even in time of warfare, is always in favor of the laws of peace and therefore of the rights and privileges of neutrals in their peaceful relations with each other and with belligerents. "Unless proof to the contrary is shown, neutral states and their subjects are free to do in time of war between other states what they were free to do in time of universal peace."'

If we apply this fundamental principle of the Law. of Neutrality to the subject under discussion, it will at once be seen that not a word can be said in favor of this absurd and monstrous innovation upon the rights of neutrals threatened by Russia. The Russians appear to have defended Admiral

noting that the Japanese also attempted to control the movements of the Haimun. In a communication printed in the N. Y. Times for May 16, the Times' correspondent stated that on April I7 he had received a communication from the British Minister at Tokio to the effect that he was requested by the Japanese military authorities not to proceed north of the Che-Foo-Che-mul-po line until further notice. He remarked that his position was difficult in the extreme. He was threatened with capital punishment by one belligerent and warned off the high seas and neutral waters by the other. He chose, however, to submit to the wishes of Japan out of deference to former courtesies on the part of the Japanese. These restrictions on the movements of the Haimun appear subsequently to have been at least partially removed by Japan.

'Lawrence, Principles, p. 474. It is unnecessary to multiply references upon this general and fundamental principle of the Law of Neutrality, which may be regarded as fully established since the close of the eighteenth century. "Till then belligerents were, on the whole, more powerful than neutrals, and were able to carry on their wars with slight regard to the sanctity of neutral territory or the convenience of neutral commerce." Lawrence, op. cit., p. 475. For the earlier practice and theory, see especially Hall, Pt. II, ch. 2. For a remarkable exposition of this fundamental principle, see Decamp, Le Droit de la Paix et de la Guerre" (1898), and an article by the same author in the Revue Générale de Droit International Public, VII (1900), pp. $629 \mathrm{ff}$. M. DeCamp's conclusions were unanimously accepted by the Interparliamentary Peace Conference at its Paris session in 1900. 
Alexieff's order on the grounds that "the correspondent on board the Haimun regularly transmitted to Che-Foo intelligence of all the outgoings and ingoings of the Russian fleet at Port Arthur," and that "the information thus conveyed might obviously have been of the highest value to the Japanese." 8

It also appears from Count Cassini's note that the fact that the use of wireless telegraphy had not been "foreseen by existing conventions" seemed to the Russian Government to afford ample justification for such an unwarranted attack upon the rights of neutral individuals. In other words, the presumption was assumed to be in favor of the rights of belligerents and against the rights of neutrals-a total misconception and reversal of one of the fundamental principles of modern International Law. Under existing law it would, as a matter of fact, require an International Convention to prohibit, or even to restrict, the use of wireless telegraphy on the high seas or in neutral territory.

In view of their ever-growing importance, it is somewhat surprising to note that the status of war correspondents is one which is seldom discussed by publicists on International Law." The "Instructions for the Government of the Ar-

${ }^{8}$ From the Novoe Vremya, quoted in the N. Y. Times for June 8, 1904

- Among the publicists who refer to the status of war correspondents are Bluntschli ( $\$ \$ 594-96$ and 638 and notes), Hall (note on p. 404 of 3d ed.), and Lawrence, Principles (p. 336). Bluntschli says that a military occupant (or invader) has the "right to detain persons, who, without belonging to the army and exercising pacific functions, are dangerous to the army of occupation," amongst whom he includes journalists whose opinions are hostile. $\mathrm{He}$ is also of the opinion that non-combatants, e.g., newspaper correspondents, contractors, etc., attached to an army which has surrendered or to troops which have been captured, may be made prisoners at least provisionally; but he thinks they ought not to be retained as prisoners of war unless "their 
mies of the United States in the Field," prepared by Dr. Francis Lieber and issued by the Secretary of War in April, r863, declare that "citizens who accompany an army for whatever purpose, such as sutlers, editors, or reporters of journals, or contractors, if captured, may be made prisoners of war, and be detained as such."10 This provision was incorporated into the "Rules of Military Warfare" adopted by the Brussels Conference of $1874 .{ }^{11}$ The Code adopted by the Institute of International Law at its Oxford Session in I 880 merely declares in favor of detention in case of necessity. It provides that "persons who follow an army without forming part of it, such as correspondents of newspapers, sutlers, contractors, etc., on falling into the power of the enemy, can only be detained for so long a time as may be required by strict military necessity." ${ }^{22}$ The "Regulations

presence in the camp of the enemy constitutes a support to the latter or a danger to the Power which has captured them." Hall seems to think that newspaper correspondents should only be detained for special reasons. Lawrence suggests that "probably the worst that could happen to them if captured in civilized warfare would be expulsion from the lines of the captors."

For fuller discussion and indication of recent practice in respect to the treatment of Journalists, see Guelle, Précis, II, $55 \mathrm{ff}$., and Pillet, Les Lois de la Guerre, pp. 194-196. For the status and treatment of newspaper correspondents in recent wars, see Revue Générale de Droit International Public, t. I (I894), p. 6o, t. III (I896), p. 80, and t. IV (1897), p. 698.

${ }^{10}$ Section III, $\S 50$ of the "Instructions." For the text of these Instructions, see, e. g., the Appendices to Tucker and Wilson's International Law and Snow's Cases.

11 "Persons in the vicinity of armies, but who do not directly form part of them, such as correspondents, newspaper reporters, vivandiers, contractors, etc., may also be made prisoners of war. These persons should, however, be furnished with a permit, issued by a competent authority, as well as with a certificate of identity." Art. 34 of the Rules of the Brussels Conference. For the English text, see App. III to Tucker and Wilson.

${ }^{12} \mathrm{Pt}$. II, \& 22, of Hall's translation of the Oxford Code. For text, see 
Respecting the Laws and Customs of War on Land," adopted by the Hague Conference in 1899 , declare that "individuals who follow an army without directly belonging to it-such as newspaper correspondents and reporters, sutlers and contractors-who fall into the enemy's hands, and whom the latter see fit to detain, have a right to be treated as prisoners of war, provided they can produce a certificate from the military authorities of the army which they were accompanying." 13

It will thus be seen that, according to existing international practice, a war correspondent, who is captured on belligerent territory and who conducts himself properly and can show proper credentials, is entitled to the privileges of a prisoner of war. In no case can he be treated as a spy. "An individual can only be considered a spy if, acting clandestinely, or under false pretenses, he obtains, or seeks to obtain, information in the zone of operations of a belligerent, with the intention of communicating it to the hostile party." 14

It may be said, however, that the use of wireless telegraphy introduces a new factor into this problem. War correspondents have hitherto been more or less subject to control, and it is clearly within the right of a belligerent either to exclude them altogether from belligerent territory

App. II in Wilson and Tucker. Cf. $\S 2 \mathrm{r}$ of the translation in App. to Snow's Cases. For the French text of the Oxford Code, see Tableau Générale de l'Institut de Droit Int., pp. 173-190.

${ }^{13}$ Art. I3. See Holls, Peace Conference, pp. 148 and 43I.

${ }^{14}$ Art. 29 of the "Regulations Respecting the Laws and Customs of War on Land," adopted by the Hague Conference. See Holls, op. cit., pp. 153 and 439. Cf. the definitions of a spy contained in the American Instructions ( $\$ 88$ ) and the Rules of the Brussells Conference ( $\$ 19$ ). They are couched in terms almost identical with those employed by The Hague Conference. 
or to place them under such supervision as may be necessary in order to control their actions. But the invention of wireless telegraphy has made it possible for them, under ctrtain circumstances, to operate either on the high seas or on neutral territory ${ }^{15}$ to an extent which was impossible before. If the use of wireless telegraphy on the high seas may be injurious to belligerent interests, might we not also conceive cases in which it would be equally injurious if operated on neutral soil? Would any one go so far as to maintain that a war correspondent, who had operated either by means of wireless telegraphy or by any other system on neutral territory, could be seized and treated as a spy under any circumstances, or even be held as a prisoner of war? A belligerent undoubtedly has the right to prohibit or prevent the transmission of cable messages (and wireless telegraphy is only a means of accelerating the transmission of messages) on belligerent territory (including the three-mile limit). So he also probably has the right to interrupt submarine telegraphic cables extending between enemy and neutral territory at any point within his own territorial jurisdiction or within that of the enemy. But he has no right to interfere with submarine telegraphic communication between two neutral territories. "On the high sea a cable can only be cut in case there is an effective blockade, and within the limits of the line of blockade." ${ }^{16}$

\footnotetext{
${ }^{25}$ In the summer of 1904 the Russians installed a wireless telegraphy apparatus at the Chinese port of Che-Foo for the transmission of wireless messages from Port Arthur. See e. g., New York Times for June 9 and II, 1904. This was a case of the use of neutral territory by a belligerent for a military purpose, but newspaper correspondents might conceivably make similar use of a neutral station. The Chinese authorities finally realized their neutral obligations and demolished the wireless station at Che-Foo toward the end of August, 1904. See Lawrence, War and Neutrality (2d ed.), pp. 218-220.

${ }^{16}$ Rule adopted by the Institute of International Law. See Annuaire,
} 
But in view of the possible injury which may result to belligerents from the use of wireless telegraphy on the high seas or on neutral territory, some concessions should perhaps be made to military necessity, provided neutral rights and interests are not seriously impaired. Interference with wireless messages by neutrals on the high seas might, under certain circumstances, be permitted to belligerents, as also the seizure and confiscation of wireless telegraphy apparatus as contraband of war, ${ }^{17}$ and neutrals should certainly refuse

XIX, p. 33I. See also Art. 5 of the Naval War Code, prepared by Captain Stockton, of the United States Navy, and issued as General Orders No. 551 on June 27 , I900. On the law of submarine cables. see especially, Scholz, Krieg und Seekabel; Renault in the Revue Générale de Droit International Public, t. XII, pp. $25 \mathrm{I}$ ff; and Wilson, Submarine Telegraph Cables, Igor.

${ }^{17}$ It may be noted that M. Pillet, Professor of International Law at the University of Paris, is quoted as having expressed a similar opinion in respect to the liability to seizure and confiscation of wireless telegraphy apparatus as contraband of war. See Army and Navy Journal for June 4,1904 . The same opinion is expressed in the Saturday $R e$ view for April 23, 1904. It is worthy of especial notice, in this connection, that Russia has placed telephonic and telegraphic material in her list of contraband of war.

Lawrence (War and Neutrality in the Far East, 2d ed., p. 92) suggests that "power should be given by international convention to exclude the vessels of correspondents for a time from any zone of sea in which important warlike operations were in process of development. Each belligerent should have a right to place an officer on board a newspaper steamer to act as censor of its messages, and the penalty for persistent obstruction and refusal to obey signals should be capture and confiscation." We do not see the necessity for such an extension of the rights of belligerents and encroachment upon the rights and privileges of neutrals. The phrase, "zone of warlike operations" is very vague, and the penalty appears to us to be unduly severe. Why punish an act which is harmless and innocent in itself by a penalty which is usually reserved for those in unneutral service?

A recent French writer (Rolland, in Revue Générale de Droit Int. $P u b$. for 1906, pp. 83 ff.) proposes that each belligerent be given the right to prohibit the emission of waves by a neutral on the high seas in a "zone corresponding to the sphere of action of its military opera- 
to permit the use of their territory for military purposes. ${ }^{18}$

The second question, wholly new, relates to the menace to neutral rights and the danger to the safety of neutral persons and property which, it was at one time feared, existed from the placing of submarine mines in Eastern waters.

In the latter part of May, I904, it was reported that the

tions." As penalty he proposes the confiscation of the apparatus if the dispatches are innocent, and of the vessel in case of unneutral service. Cf. Scholz, Drahtlose Telegraphie und Neutralität, pp. 45-46.

${ }^{18}$ Lawrence (op. cit., p. 200) properly suggests that neutral Powers ought to prevent the receipt of messages on their territory from a blockaded garrison, as in the case of the alleged Russian communication between Che-Foo and Port Arthur. He cites as a precedent the refusal by the British authorities of a request from the United States for permission to land a cable at Hong Kong from Manila during the SpanishAmerican War in 1898 , on the ground that "to grant such facility would be a breach of neutrality." But it may be well to call attention to the fact that this refusal to permit the use of neutral territory for military purposes rests upon a well-established principle of International Law, and would not apply to the use of neutral cable stations by war correspondents. Such use was made of neutral stations in Haiti (French) and Jamaica by American war correspondents during the Spanish-American War. Upon complaint of the Spanish, the English authorities in Jamaica refused to permit the use of their cable stations for the transmission of dispatches in cipher or of those relating to the war. See Le Fur, Etude sur la Guerre Hispano-Americaine de I898, p. 227.

For useful or suggestive discussions or editorials on "War Correspondents and Wireless Telegraphy," see especially Harper's Weekly for April 30, 1904; Army and Navy Journal for May 21; New York Times for April I6-19; London Times (weekly ed.) for April 22; A. Maurice Low in The Forum for July-September, and Sir John Macdonnell in Nineteenth Century for July, 1904. See also Lawrence, War and Neutrality in the Far East, pp. 83-93 and pp. 199-202; Thonier, Contrebande de Guerre (I904), ch. 6, pp. $332 \mathrm{ff}$; Woolsey in Yale Law Journal for March, I905; Rolland in Revue de Droit Int. P. for 1906, pp. 58-92; Von Kebedgy in Revue de Droit Int. et de Leg. Comp., pp. 83 ff.; and especially Scholz, Drahtlose Telegraphie und Neutralität (1905). 
Russians at Port Arthur had sown the whole strait of $\mathrm{Pe}$ chi-li with floating marine mines. "Not only have these diabolical machines been placed off their own shores and in their own waters, but it is reported that launches and junks have been sent out to drop mines at night or in fogs in waters likely to be used by the Japanese warships and transports. These mines have drifted into the high seas and Chinese waters, where they constitute the gravest danger to neutral shipping." ${ }^{10}$ It was feared by experts ${ }^{20}$ that these mines would be a menace to the lives and property of neutrals for some time to come, and that they might get out into the great ocean currents and drift about in the Pacific Ocean.

These charges against the Russians can not be said to have been fully proven, but there was certainly a strong presumption of carelessness in the laying of these submarine mines or negligence in controlling them after they were laid. It is true that our information is unofficial, but there seems to have been sufficient evidence of the existence of such mines in the open sea. ${ }^{21}$ Either these mines were deliberately laid

10 Special cablegram to the London Times and New York Times, published May 23, 1904.

${ }^{20}$ See, e. g., The Scientific American for June 4, 1904, and the Army and Navy Journal of the same date.

2 The Haimun claimed to have passed two of these mines within two miles of Wei-hai-wei, $i$. e., nearly one hundred miles from Port Arthur, on May 22. Twenty-one similar mines are said to have been discovered by vessels in various parts of the Gulf of Pe-chi-li and the Yellow Sea. The correspondent of the London Express at Wei-hai-wei estimated in the latter part of May that there were some four hundred mines floating in or near the Gulf of Pe-chi-li. The Japanese, judging from newspaper reports, seem to have been kept busy for some weeks in removing Russian mines from these waters, but the correspondent of the Chicago Daily News reported the discovery of a freshly-painted contact mine in the Gulf of Liao-tung as late as June 20, 1904. Insurance rates in London are said to have risen in consequence of the increased risks resulting from the fear of these mines. 
or set adrift on the high seas, or they were insecurely fastened in territorial waters and drifted from their anchorage out into the open sea. ${ }^{22}$

The Japanese battleship Hatsuse was generally supposed to have been blown up by such a mine on May 15, at a distance of ten miles from Port Arthur, although it was also suggested that this vessel may possibly have been destroyed by a Japanese mine or by a mine accidentally adrift. It was pointed out that such a disaster might likewise have happened to a neutral trading vessel cruising in those waters. The Russian battleship Petropavlovsk was destroyed by a Japanese mine on April 13, but this occurred on the outer roadstead of Port Arthur, i. e., in territorial waters. On the case of the Hatsuse, see especially Lawrence, $W$ ar and Neutrality, pp. 93-95, 97, and 106.

${ }^{22}$ It may be that the Japanese, too, were not wholly free from guilt in this matter of laying mines on the high seas or of negligence in securely fastening them in territorial waters; for it is known that they laid mines for the Russian fleet at several points outside Port Arthur (whether inside or outside the three-mile limit is not clearly stated), some of which are said to have been improperly anchored and were found adrift in April and May. See New York Times for April 17 and May 20. But it would be absurd to suppose that the Japanese filled the Gulf of Pe-chi-li and adjacent waters with mines to their own great danger and inconvenience. Indeed, they seem to have been put to no small expense and effort in freeing these waters from these obstacles to the freedom of their movements.

It appears that our State and Navy Departments instituted an investigation at the time in order to ascertain whether and to what extent these mines constituted a menace to neutral navigation. Our ministers at St. Petersburg and Tokio, and our naval attachés there, were instructed to look into the matter and find out what truth there might be in these reports. This information was to be given to the General Naval Board, which was then to submit its views to the President who, if he deemed it advisable, would make proper representations to the belligerents. See New York Sun for May 25, I904. The results of these investigations, if they were ever made, do not appear to have been published.

In May, I905, Minister Conger is said to have reported to our State Department that there were a number of floating mines in the Yellow Sea, which constituted a menace to neutral shipping, and to have recommended that the United States join with Great Britain and Germany in the work of destroying them. It was reported that several of these mines had been destroyed by British warships; but after careful consideration of the matter the United States Government is said to have de- 
There appears to have been no official or semi-official denial of these charges on the part of the Russian Government, although they can not be said to be fully established. The Russians seem to have justified such action on the ground that "everything is permissible in war except those things which are specifically forbidden by convention or International Law." ${ }^{23}$ It was also suggested in Russia that, because of the immensely increased range of modern guns, it is necessary to enlarge the three-mile limit for purposes of defense. It was argued that "if ships can now lie eight or ten miles away and yet reach the coast with their projectiles, the defenders have a perfect right to take such military measures as they choose within the range of the enemy's guns." ${ }^{24}$

In reply to the Russian argument that everything is permissible in war except those things specifically forbidden by International Law or Convention, it is sufficient to repeat

cided not to participate in this work. See Chicago Tribune for May 2I, 1905.

See N. Y. Times for March 26, 1905, for a chart reproduced from the London Times showing the distribution of Russian mines in the vicinity of Port Arthur. The Japanese are said to have raised 395 of these engines of destruction since the capitulation of Port Arthur. The Russians are said to have mined the whole channel between the Miao Islands and Liao-tie-Shan-a channel forty-five miles wide. See London Times (weekly ed.) for March 17, 1905.

${ }^{23}$ This is according to the St. Petersburg correspondent of the London Express. See Chicago Tribune for May 25, 1904. It appears, however, that M. de Plehve, the late Russian Minister of the Interior, in an official communication issued privately, protested vigorously against the alleged action of the Japanese in laying floating mines in the roadstead of Port Arthur, on the ground that "the wholesale scattering of these engines of destruction at points where they may easily drift into the path of the marine commerce of the world, to the common danger, can in no wise be regarded as admissible." St. Petersburg dispatch to the St. James Gazette, published in the New York Times for May 26, 1904.

${ }^{24}$ St. Petersburg dispatch in Indianapolis Journal for May 27, 1904. 
that, as in the case of the proposal to prohibit or punish the use of wireless telegraphy on the high seas or of any other new and unauthorized interference with the rights of neutrals, the presumption should always be in favor of neutral rights and privileges or of the laws of peace. In order to render such acts unlawful, it is not necessary that they be specifically forbidden; for their prima facie illegality may be deduced from general and fundamental principles. The sea is the common property and highway of all nations. It is open to belligerents and neutrals alike; but, in cases in which there is a conflict of rights or interests between the two, the presumption ought always to be in favor of neutrals. All authorities on International $\mathrm{Law}^{25}$ who have expressed

${ }^{25}$ The following is a list, as complete as we have been able to make it, of those who are reported to have expressed opinions on this interesting subject: Admiral Horsey, Sir William Walrond, M. P., Professor Moore of Columbia, Professor Woolsey of Yale, Professor T. E. Holland of Oxford, Dr. Arnold Jarvis, Sir John Macdonnell, Sir Frederick Pollock, Bart., Rev. T. J. Lawrence, and M. Pillet of the University of Paris. See London and New York Times for May 24-28, 1904. For the opinion of M. Pillet, see the Army and Navy Journal for June 4.

For useful editorials or newspaper discussions, see London and New York Times for May 24-31, I904; New York Evening Post for May 24, or the New York Nation for May 26; New York Sun for May 26; Indianapolis Journal for May 27; London Spectator and Saturday News for May 28; Army and Navy Journal for May 28, and June 4; Scientific American for June 4; Bradstreet's for May 28; Public Opinion for June 2; Berliner Nachricht for May 29; and Die Woche for June 4.

"If these mines were deliberately floated into waters where they would be liable to endanger neutral ships, the act was undoubtedly inadmissible." (Professor Moore in New York Times for May 25.) "Mines, whether anchored or intentionally set adrift in the Strait or Gulf of Pe-chi-li, beyond the coast sea limit, constitute an undiscriminating attack upon neutral and belligerent alike, and are, therefore, illegitimate." (Professor Woolsey in the New York Times of the same date.)

"The laying of mines in the open sea beyond the territorial waters would seem, not only inhuman, but a breach of International Law and 
themselves on this subject are, so far as we are aware, unanimously of the opinion that if either or both of the belligerents in this war were guilty of deliberately sowing any portion of the high seas with floating mines, they committed - to put it mildly - a gross violation of the laws of civilized warfare and of International Law. The majority of these authorities seem to be of the opinion that this was the case,

practice. . . . If it should prove true that the destruction of the Hatsuse was effected by a mine wilfully placed in the open sea, ten miles from land, the act appears to me one of wholesale murder, and its perpetrator hostis humani generis." ( Admiral Horsey in London Times and New York Times for May 24, 1904)

"It is certain that no international usage sanctions the employment by one belligerent against another of mines or other secret contrivances which would, without notice, render dangerous the navigation of the high seas." (Professor Holland in London Times and New York Times for May 25, 1904)

"Every belligerent is free, I take it, to destroy his opponent's vessels in territorial waters or on the high seas by all customary means, including the use of mines. If, in an attempt to sink an enemy's ship, he accidentally destroys neutral property, there would be an unanswerable claim for damages done on the high seas. . . . If, on the other hand, and $I$ hesitate to believe it, mines are scattered broadcast in waterways outside territorial limits, neutrals who suffered would have $\mathrm{just}$ cause to complain. Such conduct, if persisted in, would afford ground for remonstrance and, it might be, extreme measures." (Sir John Macdonnell in London Times and New York Times for May 25, 1905.)

"If a mine-field was deliberately created out in the open ocean by the Russians, in such a position that it was as likely to destroy a peaceful neutral as an enemy's warship, words fail to express the reprobation with which the act must be regarded. It is not only illegal, but cruel to the highest degree." (Lawrence, War and Neutrality in the Far East, p. 107.)

The only discordant note which we have detected in this general chorus of denunciation, at least on the part of British and American authorities, was that voiced by Admiral Sir Cyprian Bridge of the British Navy. See London Times and New York Times for May 31, I904. Officers of the British Navy were said to be opposed to any limitations upon the rights of naval warfare. Officials of our own War and Naval Departments do not seem to have entertained such fears or prejudices. See New York Times for May 25, 1904. 
whether the mines were anchored or intentionally set adrift outside the three-mile limit. If neutrals had suffered injury from mines which were accidentally set adrift or which had floated out into the open sea in consequence of having been insecurely fastened in territorial waters, there would seem to have been good ground for a claim for damages; if, on the other hand, it had been proven in such a case that the mines were deliberately placed there, severe measures would probably have been taken by the neutral Powers concerned.

There can, of course, be no question, in the present state of license in the use of submarine mines and torpedo boats ${ }^{28}$ and other highly destructive weapons of modern warfare, but that states have a right to employ these devices in their own harbors and territorial waters (as also in those of the enemy) within the three-mile limit, provided that the life and property of neutrals and non-combatants be not carelessly or wantonly jeopardized. ${ }^{27}$ It is also probable that they have the right to use these weapons outside of territorial waters, $i$. e., on the high seas, with the specific aim of injuring or destroying, or of obstructing and impeding the movements of an enemy fleet, provided no injury which can possibly be avoided result to neutrals. ${ }^{28}$

${ }^{28}$ Count Mouravieff's proposal to "prohibit the use, in naval warfare, of submarine topedo-boats or plungers, or other similar engines of destruction," and of "new explosives, or any powders more powerful than those now in use," did not meet with the approval of the majority of the states represented at the Hague Conference. See Holls, Peace Conference, p. 26 and pp. 94-95. This does not affect neutral rights, however, as the New York Nation (May 26, I904) seems to think.

${ }^{2 \pi}$ Neutrals using or approaching these ports or waters are entitled to notice or warning. Whether such notice or warning should be general or specific would probably depend upon circumstances.

${ }^{28}$ Such injury, if not due to the fault of the neutral, would undoubtedly justify a claim for damages. There seems to be this difference be- 
Centuries of practice show that belligerents have an undoubted right to engage in battle on the high seas. Neutrals must take cognizance of this right and keep out of the range of the guns, as well as abstain from impeding or obstructing the movements of the vessels of either belligerent. Belligerents can not be held responsible for injury to a neutral resulting from the latter's own carelessness or intrepidity. On the other hand, the belligerent should be held to strict account for any injury which neutrals may suffer as a result of the belligerent's own carelessness or negligence, or from the use of weapons, such as submarine mines, as to the existence of which, in that particular locality, the neutral has no knowledge. Even if notified, neutrals could hardly be expected to take cognizance of the existence of mines on the high seas within what has loosely been termed the "theater or zone of warlike operations." This would be a new and hitherto unheard-of restriction on the rights of neutrals which could not be imposed without an international agreement, the enactment of which should be resisted to the utmost by all seafaring nations. ${ }^{29}$

In respect to the argument that, owing to the increased range of modern artillery, the three-mile limit ought to be increased for purposes of defense, it may be admitted that there is much force in this contention. For the protection

tween the rights and privileges of neutrals on the high seas and in territorial waters: the neutral uses the high seas as a matter of right, and the presumption is in his favor; in territorial waters, the neutral is exercising a mere privilege, and the presumption is in favor of the belligerent.

${ }^{20}$ It may be that there are exceptions to the principles enunciated above. For example, a belligerent would probably have the right to defend the anchorage of its vessels or to block up the ships of the enemy by the use of mines outside the three-mile limit. The use of such mines would doubtless also be legitimate in the case of blockade. 
of besieged fortresses like Port Arthur, it would certainly seem only fair to the besieged that the three-mile limit be extended in their behalf and that they be allowed every means of defense (including mines) permitted by the laws of warfare at any point within the range of modern guns. Such is not the law, ${ }^{30}$ however, and a change in the law would require an international agreement or a complete change in international practice. ${ }^{31}$

The three-mile limit or the marine league was originally based upon the principle first clearly enunciated by the Dutch jurist Bynkershoek ${ }^{32}$ in the early part of the eighteenth century, to the effect that the sovereignty or jurisdiction of a state over the seas extends no farther than its power to defend the sea coast by force of arms-terra dominium finitur ubi finitur armorum vis, i. e., quousque tormenta explondunter. The range of the cannon of that day seems to have been about a marine league or three geographical miles; and this distance became the generally, if not universally, recognized limit of territorial waters in the course of the eighteenth century. In the course of the nineteenth century

${ }^{20}$ But even if this were the law, it would not justify the placing of mines in the open sea, e.g., in the neighborhood of Wei-hai-wei, or such acts as the blowing up of the Hatsuse ten miles southeast of Port Arthur.

" "The United States can not admit that Spain, without a formal concurrence of other nations, can exercise exclusive sovereignty upon the open sea beyond a line of three miles from the coast. . . . It can not be admitted that the mere assertion of a sovereign, by an act of legislation, however solemn, can have the effect to establish and fix its external maritime jurisdiction. This right to a jurisdiction of three miles is derived, not from his own decree, but from the law of nations." Secretary Seward to M. Tessara, Dec. 16, I862, and Aug. 10, 1863. See Wharton's Dig. I, § 32, pp. 102-103.

${ }^{2}$ De Domino Maris, ch. 2. This work was published in 1702 or 1703. Cf. the vaguer statements of Grotius (Lib. II, ch. 3, \$8 13, 14) and Vattel (Liv. I, ch. 23, 8289 ). 
the rule of the marine league appears to have completely supplanted the principle upon which it was originally based and, instead of being extended to meet the demands of new modern guns of ever-increasing range, it remained always the same, until it is now as fixed and unalterable apparently as were the laws of the Medes and the Persians, in spite of the protests of publicists and the efforts of statesmen. ${ }^{33}$

There can be no doubt that an extension of the three-mile limit for all territorial purposes would be highly desirable. The marine league no longer satisfies the demands of modern requirements of defense. An extension to meet these requirements is certainly favored by an ever-increasing majority of modern publicists, and has been strongly recommended by the Institute of International Law. ${ }^{34}$

ss The majority of modern publicists appear to favor an extension of the three-mile limit, but some of them do not clearly distinguish between the present three-mile rule and the principle upon which it was originally based. Among those who may be cited as favoring an extension of the present rule or as holding that Bynkershoek's principle is, or ought to be, the rule of International Law, are Bluntschli, 8302 ; Fiore, $\$ 788$; Calvo, I. $\$ 356$; P. Fodéré, II, $\$ \S 360 \mathrm{ff}$; Hautefeuille, I, 89, 239; Ortolan, I, ch. 8; Heffter, § 75; Rivier, I, Liv. III, ch. I, § 10; Phillimore, Pt. III, ch. 8; Hall, § $4 \mathrm{I}$; Taylor, \$ 247.

In 1806 the American Government attempted to obtain a recognition of a six-mile limit from England, but refused to acknowledge the validity of a claim of six miles made by Spain to the coast of Cuba in 1863. But in the following year (I864) Secretary Seward proposed a zone of five miles to the British Legation at Washington. The British Government has, however, always insisted upon the three-mile limit.

The three-mile limit has the sanction of a considerable number of State and International Acts or Conventions, e. g., the Russian Prize Rules of 1869 , the British Territorial Waters Jurisdiction Act of 1878 , the North Sea Fisheries Convention of 1882, the Convention of Constantinople relating to the Suez Canal of 1889 . For list of treaties see Calvo, I., p. 479.

* The Institute of International Law, at its Paris session in 1894, after an exhaustive discussion of this question, gave a decisive majority (there was no division of opinion as to the desirability of extending the 
It is highly desirable that these questions, as well as many others which have arisen, more particularly those relating to neutrality, contraband, and naval warfare, be discussed and, if possible, settled by the coming Hague Conference. In respect to the questions immediately under discussion in this chapter, it may be said that any claims for damages which may arise in the future in consequence of injury to neutrals from submarine mines should be referred to arbitration, preferably to the Hague Tribunal; but to wait until injury has actually resulted to neutral individuals or to neutral property before laying down the rule to be followed in such cases would not seem to be the part of wisdom or sound policy. Precautions should be taken in time, and any evil consequences which might follow upon uncertainty as to the rule ought to be averted, if possible. In respect to the laying of submarine mines, the very least that neutral states have a right to demand is that these highly dangerous explosives be restricted to territorial or belligerent waters; or, if their use be permitted upon the high seas for any purpose whatsoever, that they be anchored in such a way that they can not possibly become a menace to neutral vessels. In all such cases neutrals should receive due notice and the mines should be carefully removed after the special purpose for which they have been placed there has been fulfilled. ${ }^{35}$

three-mile limit) in favor of a zone of six marine miles for all territorial purposes and of permitting neutral states to extend it still farther in time of war for the purpose of defending their neutrality against a belligerent Power, provided the range of cannon was not exceeded. The maritime Powers were recommended to hold an International Congress for the purpose of adopting these and other rules, but no such Congress has ever been held. See Annuaire de l'Institut de Droit International for $1894-95$, pp. $28 \mathrm{I}-33 \mathrm{I}$.

${ }^{35}$ Oppenheim (II, $\S 182$, p. 190), one of the most recent authorities on International Law, is of the opinion that "the matter ought to be regu- 
lated in the following way: Every belligerent is allowed to drop floating mechanical mines inside his own or the territorial waters of the enemy, provided warning is given to neutrals to avoid the waters concerned. On the open sea no dropping of such mines is allowed except inside a line of blockade. In any case, all floating mines must be properly moored, so as to prevent, as far as possible, their drifting away. Under no circumstances and conditions is it allowed to set floating mines adrift."

Note.-At its recent session held in Ghent during the last week of September, 1906, the Institute of International Law adopted a series of articles relative to wireless telegraphy and submarine mines of which the following is a summary based on the best available accounts :

The regulations governing wireless telegraphy in time of peace are applicable in principle in time of war.

Belligerents may prevent the transmission of Hertzian waves by a neutral state over the high seas within the sphere of their military operations.

All persons taken prisoner while receiving or transmitting wireless messages from belligerent territory or between different sections of a belligerent army, are not to be considered spies, but are to be treated as prisoners of war, unless their operations were carried on under false pretenses.

Neutral ships and balloons proved to have been used to furnish an adversary with information helpful in the conduct of hostilities may be removed from the zone of hostilities and the wireless apparatus on board seized and sequestered.

A neutral state is not obliged to prevent the passage across its territory of Hertzian waves destined to a country at war. A neutral state has the right to close or take over the wireless telegraph station of a belligerent operated in its territory.

It is forbidden to place fixed or hidden mines in the open sea. Belligerents may place mines within their own waters and the waters of the enemy, with the exception of floating mines, or fixed mines liable to break loose and be a menace to navigation in waters not belonging to belligerents. The foregoing regulation applies to neutral states wishing to place mines in their own waters to prevent the violation of neutrality, but neutral states can not place such mines in the neighborhood of straits leading to the open sea. A belligerent, as well as a neutral state, must give due notification of the placing of mines. Any state violating the foregoing regulations will be held liable. 


\section{CHAPTER V}

Russian Seizures of Neutral Merchantmen-The Right of Visit and Search and the Alleged Right of Destroying Neutral Prizes

The most important questions of International Law bearing upon the rights of neutrals which arose during the Russo-Japanese War grew out of the exercise of the right of visit and search for contraband of war and from the seizure of neutral vessels in the Red Sea by several cruisers of the Russian Volunteer Navy, as also the seizure and (in two cases) the sinking of neutral prizes in the Pacific Ocean by the Vladivostok squadron during the month of July, 1904 .

Complaints were heard almost at the very beginning of the war against the searching and detention of neutral merchantmen by the Russian Mediterranean fleet in the Red Sea and against the detention of several British and American ships at Port Arthur. ${ }^{1}$ The temporary detention of the British and American vessels at Port Arthur, whether due

\footnotetext{
${ }^{1}$ It was also reported by Admiral Alexieff that the German cruiser Hansa, engaged in transporting German subjects from Port Arthur, was fired upon by Japanese warships; but the circumstances were not described, and, according to Admiral Alexieff's own admission, the vessel appears to have harbored Russians in the guise of Germans. The incident seems to have attracted but little attention. From the military correspondent of the London Times, February 17, 1904.

A British steamer (the $F u$ Ping) was also fired upon by a Russian guardship as it was leaving Port Arthur. This was said by Admiral Alexieff to have been due to a misunderstanding.
} 
to the fact that they harbored Japanese refugees ${ }^{2}$ or whether caused by motives of military expediency, ${ }^{3}$ does not seem to have been regarded as a serious matter by either of the neutral Governments concerned, although there appears to have been some diplomatic correspondence on the subject, and, in one case at least, a claim for the payment of demurrage. ${ }^{4}$ It is probable that the temporary detention for military purposes of neutral merchantmen in a beseiged or blockaded port, more particularly at the beginning of a war, would be regarded with a certain degree of leniency by friendly neutrals. A payment of demurrage by the belligerent government to the neutral owners is probably the utmost that would be expected by a neutral government ${ }^{5}$ under these circumstances.

A much more serious matter was the stopping and searching of a number of neutral merchantmen in the Red Sea by the Russian Mediterranean fleet on its return from a projected voyage to the Far East during the second week of the war. Three neutral colliers ${ }^{6}$ laden with steam coal (which was doubtless destined either directly or indirectly for

${ }^{2}$ As reported in the case of the British steamer Wen Chow. See London Times (weekly edition), February I9, I904.

'The American steamship Pleiades was by some supposed to have been detained for strategic reasons. See New York Times for February 14, 1904 .

"We note that the Russian Government granted compensation to the owners of the British vessel-the steamer Foxton Hall-for loss sustained during her detention at Port Arthur in February. See New York Times for August 4, 1904.

'It would, of course, be different in the case of a war vessel.

- Two of them, the Frankly and the Ettrickdale, were British and one, the Matilda, was Norwegian. For a summary of the facts see Lawrence, War and Neutrality (2d ed.), pp. I 4 f. The Russian Government agreed to indemnify the owners of the British colliers Frankly and Ettrickdale. See New York Times for September 10, I904. 
Japan) were seized and brought as prizes into the Gulf of Suez within Egyptian territorial waters. Here they were detained for about four days, and in the meantime these waters were used as a base of anchorage from which to overhaul neutral vessels, in spite of the protests of the Egyptian Government. The colliers were soon released, however, in response to a telegraphic order from the $\mathrm{Czar}$, on the ground that these captures had been made before the Russian Government had fomally declared coal contraband of war.

The return of the Russian Mediterranean fleet to the Baltic, the prolonged inactivity of the Baltic fleet, and the practical bottling up or blockade of the Russian fleet at Port Arthur almost from the beginning of the war, left the control of the high seas and of contraband trade in the hands of neutral nations and the Japanese, except for an occasional sortie by the Vladivostok fleet which inflicted some serious damage upon Japanese transports. There seems to have been no serious interference with neutral trade until the seizure of the Allanton on June 16 and the Cheltenham early in July, 1904, ${ }^{7}$ for the carriage of contraband.

These seizures had excited some interest and controversy, when the world was suddenly electrified by the news that two cruisers, the Peterburg and the Smolensk, belonging to the Russian Volunteer fleet in the Black Sea, had made their way early in July, 1904, out of the Bosporus and the Dardanelles into the Mediterranean as merchantmen (both of them flying the commercial flag), passed through the Suez Canal, and were holding up and seizing neutral vessels in the Red Sea. ${ }^{8}$ These vessels had apparently passed through

T These seizures will be discussed in the next chapter.

${ }^{8}$ The Russian Volunteer steamer Sevastopol was also reported to have passed the Bosporus on July 6, in company with the Peterburg. 
the Straits (as, indeed, appears to have been their custom for some years past) without protest from Turkey or the Powers; but a terrible storm of indignation was excited in England when it was learned that the British liner Malacca, belonging to the Peninsula and Oriental Navigation Company and bound for Yokohama via Hong Kong, had been arrested by the Peterburg in the Red Sea on July $13^{\circ}$ on a charge of carrying contraband, and was being brought to Port Said through the Suez Canal as a prize in the custody of a Russian prize crew and flying the Russian flag. At about the same time much excitement was created in Germany by the news that the German mail steamer Prinz Heinrich had been stopped by the Smolensk on July I 5 and that a portion of her mail destined for Japan (two mail bags for Nagasaki) had been confiscated, the remaining portion having been transferred to the British steamer Persia, which was forcibly detained for that purpose. ${ }^{10}$

Both the British and German Governments at once entered vigorous protests against what they regarded as violations of neutral rights. The German Government claimed that, while "the exercise of the droit de visite in the case of mail steamers may perhaps be justifiable, the confiscation of mail bags directly contravenes the provisions of International

She was said to be flying the Red Cross flag in addition to the commercial flag. It was also learned that the Russian guardship Chernomoretz, a gun vessel belonging to the regular Black Sea fleet, had been sent through the Straits on July I6, but it was subsequently stated that this vessel had gone to the Piræus in Greece on its usual voyage.

- The news did not reach the public before July 17, rg04. Several British vessels had been visited and searched prior to the seizure of the Malacca, but these had merely been detained for a short time.

${ }^{10} \mathrm{~A}$ section of the English press had commented very strongly upon the detention and search of the British mail steamer Osiris by the Russian gunboat Krabri early in May, 1904. See Lawrence, op. cit., p. 185. 
Law."11 It asked for a disavowal of the Smolensk's action and the return of the captured mail bags. These demands were readily agreed to by the Russian Government, and the German Government was assured that the confiscated mail sacks would be returned as soon as possible, and that the German mails would not again be molested by the Russian auxiliary cruisers. Russia also agreed to indemnify the German shippers and consignees for any losses sustained on account of the seizure of the German ships and the detention of German mails.

The British Government, in addition to a protest and a demand for the immediate release of the Malacca which appears to have amounted to an ultimatum, is said to have instructed the British Mediterranean fleet under the command of Admiral Domville ${ }^{12}$ to patrol the Red Sea and prevent any further molestation of British steamers by Russian merchantment suddenly transformed into warships. Charges of "piracy" were freely made by the most conservative London newspapers, and public opinion in England appears to have been a unit in support of the firm attitude of the British Government.

The British protest against the seizure of the Malacca was partly based upon the ground that part of the contraband which the steamer was alleged to be carrying consisted of British Government stores (forty tons of lyddite, each case of which was marked with the broad arrow or Government

${ }^{11}$ See London Times (weekly edition) for July 22, I904. Germany does not seem to have raised the question of the status of the Smolensk.

${ }^{12}$ Admiral Domville is reported to have detached two of his cruisers with orders to proceed to Port Said, with a view of retaking the $M a$ lacca in case an effort were made to take her to a Russian prize court. They fortunately failed to reach Port Said before the departure of the Malacca from that port. 
stamp) consigned to the British naval station at Hong Kong and intended for the use of the British-China squadron. Sir Charles Hardinge, the British ambassador at St. Petersburg, also presented a general protest against the exercise of the right of search and seizure by vessels of the Russian Volunteer Navy, the question of the right of these vessels to pass the Bosporus and Dardanelles not having been directly raised. ${ }^{13}$ The Russian officials contended, on the other hand, that the Malacca, in addition to British Government stores, had on board munitions of war intended for the use of the Japanese, and that the captain of the Malacca had refused to show the manifest of his cargo. ${ }^{14}$

The Russian Government, acting, it is said, in accordance with the personal wishes of the Czar and upon the advice of the French Government, finally (on July 2I) consented to release the Malacca upon the assurance of the British Government that the war munitions on board the vessel were British Government stores, and after a perfunctory or pro forma examination of the cargo by a British and Russian consul. ${ }^{15}$ Russia also promised that no similar incident should occur in the future, and agreed to instruct the officers of her Volunteer Navy to refrain from interference with neutral shipping in the future on the ground that "the present status of the Volunteer fleet was not sufficiently well defined, according to International Law, to render further

${ }^{13}$ The British Government appears to have raised the question of the status of the vessels of the Russian Volunteer fleet rather than to have charged Russia with a violation of the Treaties of Paris and London.

${ }^{14}$ This was, however, emphatically denied by the Secretary of the Peninsular and Oriental Navigation Company. See letter to the London Times (weekly ed.) for August 5, 1904.

${ }^{28}$ This examination was held at Algiers on July 27, and the vessel was released in accordance with this agreement. 
searches and seizures advisable." There was no agreement in principle on the broader question of the right of the passage of the Straits on the part of these vessels, ${ }^{16}$ and considerable excitement was caused in both England and Germany by the subsequent seizure of one German and several British ships ${ }^{17}$ in the Red Sea; but these seizures were said to have been due to a failure on the part of the Russian Government to convey to the captains of the Russian cruisers a new set of instructions in time to prevent such action. They were speedily released on July 27 , on the same day and on the same terms as in the case of the Malacca. ${ }^{18}$

No sooner had the case of the Russian detentions and seizures in the Red Sea been thus practically disposed of than there was renewed excitement in consequence of the news

${ }^{16}$ This is based on Premier Balfour's statement to the House of Commons on July 28. See, e. g., New York and London Times for July 29, 1904. See also Lord Landsdowne's statement to the House of Lords on the same date.

${ }^{17}$ The German Scandia and the British Ardova and Formosa. The cargo of the Ardova is said to have included military supplies consigned to the United States Government at Manila.

${ }^{18}$ See the London Times and New York Times for August 26, 1904, and Lawrence, $o p$. cit., pp. 215 f. It was now generally assumed that there would be no further trouble of this kind; but in the latter part of August, I904, the British public was again excited by the news that the Smolensk had appeared in South African waters on August 21, and had visited the British Steamer Comedian. Count Lamsdorff, the Russian Minister of Foreign Affairs, explained that the instructions to abstain from further searches and seizures had failed to reach the Smolensk, and he took the extraordinary and humiliating step of requesting the British Government to convey to her officers the orders of the Russian Government. It was reported that no less than seven vessels were sent out by the British Admirality to find this cruiser which was finally discovered off Zanzibar on September 7. She apparently condescended to yield obedience to the orders received through the hands of the British Government, for she gave no further trouble and one of the most exceptional and extraordinary incidents in the history of naval warfare and International Law was closed. 
that several neutral as well as Japanese merchant vessels had been sunk on July 23 and $24,1904,{ }^{19}$ by the Vladivostok

${ }^{10}$ The British steamer Hipsang was also reported to have been torpedoed and a portion of its crew drowned or wounded by the Russians in Pigeon Bay, near Port Arthur, on July 16; but this act, which occurred in belligerent waters, does not seem to have excited much interest or controversy, and it belongs to an entirely different order of phenomena from those discussed in the text. One reason given by the Russians for the destruction of the Hipsang was that the steamer refused to stop when ordered to do so. (See special cable to London and New York Times from Shanghai, July 26); another was that they mistook her for a Japanese vessel. (See Associated Press dispatch in New York Times for August 5.) A British navel court of inquiry held at Shanghai on August 22 exonerated the captain of the Hipsang and found that he acted correctly in all respects. It denied that he refused to stop when ordered to do so, and claimed that there was no contraband, and that there were no Japanese on board the vessel. See New York Times for August 24, and London Times (weekly ed.) for August 26, 1904 See also Lawrence, op. cit., pp. 259-60.

It will be seen from the above scattered and fragmentary reports that it is not at all clear what the charges against the Hipsang really were. In any case, whether carrying contraband or engaged in an unneutral service, she should not have been destroyed, except in case of necessity or of continued or obstinate resistance to arrest. If the finding of the British naval court of inquiry is correct, it would seem that a great and wanton outrage was committed and that the owners of the vessel were entitled to indemnity and the British Government to an apology.

For the finding of the British Naval Court at Shanghai, see London Times (weekly ed.) for November 25, 1904. It shows the destruction of the Hipsang to have been entirely unjustifiable.

Several other neutral vessels are also said to have been sunk by the Russians later in the struggle, e. g., the British steamers St. Kilda and Ikhona on June 5, and the Danish steamer Princess Marie on June 22, 1905. These vessels appear to have been guilty of the offense of "carrying contraband." In response to representations on the part of the British Government, Count Lamsdorff handed to Sir Charles Hardinge, the British ambassador at St. Petersburg, instructions from the Russian Admiralty to captains of cruisers ordering them to abstain from sinking neutral vessels. The instructions are said to have been delivered by British warships. See London Times (weekly ed.) for June 30, 1905, p. 403. Early in August, 1905, we heard of another British steamer, the Oldhama, which had run ashore at Urup Island, a part of whose crew was rescued by the Japanese. London Times (weekly ed.) for 
squadron in one of its occasional sorties on the Pacific Ocean -viz., the Knight Commander, a British steamer with an American mixed cargo (including flour and railway materials) from New York consigned to various Eastern ports, and the Thea, a German merchantman with a cargo of canned fish consigned to Japanese ports. At about the same time (July 25), news was received of the capture (on July 22) of the Arabia, another German vessel with an American cargo of flour and railway material consigned to Japanese ports, and the seizure of the British steamer Calchas, with a cargo of flour and machinery destined for Japan, on July $26 .^{20}$

The sinking of the Thea appears to have excited very little interest in Germany, but the sinking of the Knight Commander created a storm of indignation in England which almost rivalled, if, indeed, it did not surpass, that caused by the seizure of the Malacca. It was condemned on all sides as a gross outrage on the rights of neutrals and a serious violation of International Law. ${ }^{21}$ The British Government entered an energetic protest at St. Petersburg against the sinking of the Knight Commander on the ground that "it is not proper that, on the authority of the captain of a cruiser, goods alleged to be contraband of war should be taken from

August 11, 1905, p. 499. It would be an interesting question in social psychology to ascertain why these seizures and sinkings did not excite the mind of the British public as did the sinking of the Knight Commander.

${ }^{20}$ These cases, which involve questions of contraband, will be considered in the succeeding chapter.

${ }^{21}$ Even Premier Balfour stated in the House of Commons that it was "contrary to the practice of nations in war time," and Lord Lansdowne characterized it in the House of Lords as a serious breach of International Law," and an outrage. See New York Times for July 29, I904. 
a merchant ship without trial." ${ }^{22}$ It is believed that the Russian Government was requested to make ample amends by way of apology and reparation for this "outrage," and it certainly received an intimation from the British Government to the effect that a repetition of acts similar to the seizure of the Malacca and the sinking of the Knight Commander would not be tolerated by the English people. ${ }^{23} \mathrm{~A}$ strong protest against the Russian doctrine of contraband

${ }^{22}$ See Premier Balfour's statement in the House of Commons, cited above. He added: "The proper course, according to international practice, is that any ship reasonably suspected of carrying contraband of war should be taken by the belligerent to one of its own ports, and its trial should there occur before a prize court, by which the case is to be determined. Evidently, if it is left to the captain of a cruiser to decide on his own initiative and authority whether particular articles carried on a ship are or are not contraband, what is not merely a practice of nations, but what is a necessary foundation of equitable relations between belligerents and neutrals would be cut down to the root." "Under no hypothesis," said Lord Landsdowne in the House of Lords, "can the Government conceive that a neutral ship could be sunk on the mere fiat of a cruiser's commanding officer, who assumed that the cargo of the vessel included articles which were contraband." $C f$. Lord Lansdowne to Sir C. Harding, Dispatch No. 20 in Parliamentary Blue Book on Russia, No. I (1905).

23 "You should make it clear that should the Russian Government act upon their extreme contentions with regard to contraband of war, and the treatment of vessels accused of carrying it, His Majesty's Government will be constrained to take such precautions as may seem to them desirable and sufficient for the protection of their commerce." Lord Lansdowne, to Sir C. Hardinge in Dispatch, cited above. The Department of State at Washington also informed the Russian Government on July 30, 1904, that if it be the case, as represented, "that the Knight Commander was under American charter and was carrying American property . . . the Government of the United States would view with the gravest concern the application of similar treatment to American vessels and cargoes, and that this Government reserves all rights of security, regular treatment, and reparation for American cargo on the Knight Commander and in any seizure of American vessels." House Doc. of 58th Congress, 3d session (Foreign Relations, 1904), p. 734. 
was also made by the British as well as by the American Governments at the same time (August 10, 1904).

The Russian Government in its reply appears to have expressed its willingness to make reparation provided it were shown to have been guilty of a violation of any principle of International Law, but to have strenuously insisted at the same time that there had been no such violation. It justified its right to sink the Knight Commander on the ground that the vessel contained contraband of war, viz., railway material and machinery, and because her captor was "unable to bring her to the nearest Russian port without manifest danger to the squadron, owing to her not having enough coal." 24

It was also urged that such action was entirely in accord with the Russian Prize Regulations as well as the principles of International Law. Owing to the strong position taken by the British Government, the Russian Government agreed, however, to have the case reviewed by a special Admiralty Court at St. Petersburg., ${ }^{25}$ and consented to modify its instructions to its naval commanders on certain points. They were accordingly instructed" ${ }^{26}$ on August 5 "not to sink

${ }^{24}$ See the report of Vice-Admiral Skrydloff in the New York Times for August 3, 1904. See also the Russian official report in London Times (weekly ed.) for August 12, 1904. It was also charged that the Knight Commander did not stop until after several blank shots had been fired. (Admiral Skrydloff's report says two, the Russian official report says four shots were fired.) Such resistance might, if proven, be held to justify condemnation, but could not possibly justify the sinking of the vessel except as the result of a struggle.

${ }^{25}$ The Vladivostok Prize Court had rendered a decision justifying the sinking of the vessel. See London Times (weekly ed.) for August 12, 1904. The British Government refused, however, to be satisfied with this verdict.

${ }^{20}$ In spite of these instructions one Danish and several British vessels were sunk by Russian cruisers belonging to Admiral Rojestvensky's ill- 
neutral merchantmen with contraband on board in the future except in cases of direst necessity, but in cases of emergency to send prizes into neutral ports." 27 The decision of the Vladivostok Prize Court which condemned the Knight Commander was subsequently reversed by the Admirality Court at St. Petersburg, and an indemnity of about $\mathfrak{E}$ Ioo,000 was paid by Russia to the British Government. ${ }^{28}$

These seizures and the destruction of neutral prizes raise a number of very important questions in International Law, but the most important of these, viz., those connected with the subject of contraband of war, will be reserved for a separate discussion in the next chapter. The discussion in this chapter will be confined to questions relating to the right

fated Baltic fleet in June, 1905:-the British steamer St. Kilda by the Russian cruiser Dneiper on June 5 in the China Sea (see the Chicago Tribune for June 19, and London Times-weekly ed.-for July 14, 1905); the British mail steamer Ikhona by the Russian cruiser Terek in the China Sea on June 5. (See London Times-weekly-for June 30, 1905); and the Danish vessel Princess Marie by the Terek on June 29. The only circumstantial account we have is that concerning.the sinking of the Ikhona by the Terek. It appears that the cargo of the Ikhona, a British steamer carrying mails from Rangoon to Yokohama, consisted mainly of rice and wheat. As soon as the captain of the Terek boarded her, he observed; "This is contraband. We must sink you as we are unable to convey you." The officers and crew of the Ikhona were treated with the greatest kindness and consideration. See London Times cited above, p. 403 .

${ }^{27}$ Chicago Tribune for August 6, 1904. In her reply of August 12 to the British representations, Russia is reported to have refused to recede entirely from her position as set forth in her "Prize Regulations," and to have reserved the right to destroy, in cases of emergency, neutral vessels carrying contraband. At the same time she is said to have assured Great Britain that no more neutral vessels would be sunk unless circumstances should render it impossible to bring them before a prize court. St. Petersburg dispatch to the Chicago Tribune for August 12, 1904.

${ }^{28}$ See London Times (weekly) for March 17, 1905. 
of visit and search, of capture, the seizure of mails, and the destruction of neutral prizes on the high seas.

The most important question of International Law arising from the seizures in the Red Sea was that the status of the cruisers belonging to the Volunteer Fleet of the Russian Navy. It was not, as frequently stated in the newspapers, the question as to whether these vessels had the right to pass through the Bosporus and the Dardanelles with or without the distinct purpose of being converted into warships. That is a question of international policy and treaty interpretation rather than of International Law. ${ }^{29}$

The right of visit and search of all neutral merchantmen on the high seas by all lawfully commissioned ${ }^{30}$ warships of

${ }^{20}$ According to a series of great international treaties, warships are not allowed to pass through the Straits, but merchant vessels are expressly permitted to do so. The present rule goes back to the London Treaty of $184 \mathrm{I}$, which sanctioned the ancient rule of the Ottoman Empire forbidding all foreign ships of war from entering these waters. These stipulations were reaffirmed by the Treaty of Paris (1856), the London Conference ( $187 \mathrm{I})$, and the Treaty of Berlin (1878). It has been claimed that Russia and Turkey entered into a convention in I89I to permit the passage of the Straits by vessels belonging to the Russian Volunteer Navy, but Premier Balfour disclaimed all knowledge of such an agreement in the House of Commons. Certain it is that Russia has been in the habit for some years of sending these vessels through the Straits under her merchant flag. The British Government appears to have been saving its rights by occasional protests.

The vessels of modern Volunteer Fleets or Auxiliary Navies occupy a new and somewhat anomalous, although fully established, position in modern warfare and International Law. They are in theory merchantmen when nations are at peace, but may readily be converted into warships in time of war. Those belonging to Russia have crews which are subject to naval discipline and are under the control of officers of the Russian Navy. Originally built by a great voluntary subscription shortly after the Russo-Turkish War of $1877-78$, they are at all times in the service of the state to which they belong, and are used for military as well as for commercial purposes.

so "In the absence of a commission, a right of search and capture does 
a belligerent government is one which has never, so far as we are aware, been denied by any one, least of all by Great Britain, the great champion of belligerent rights on the high seas. As Lord Stowell (then Sir W. Scott), perhaps the greatest prize court jurist the world has ever seen, said in I799 in the famous case of the Maria (I Robinson, 359): "The right of visiting and searching merchant ships on the high seas, whatever be the ships, whatever be the cargo, whatever be the destination, is an incontestable right of the lawfully commissioned ship of a belligerent nation. . . . This right is so clear in principle that no man can deny it who admits the legality of maritime capture, because if you are not at liberty to ascertain by sufficient inquiry whether there is property that can be legally captured, it is impossible to capture. . . . The right is equally clear in practice." "It is," admits Premier Balfour, "undoubtedly the duty of a captain of a neutral ship to stop when summoned to stop by a cruiser of a belligerent and to allow, without difficulty, his papers to be examined." 31 Resistance, whether real or con-

not exist as against neutrals." See Taylor, Public International Law, p. 497 , and the cases there cited.

${ }^{31}$ Premier Balfour in the House of Commons on July 28, 1904. In his remarks to the House of Commons on August Ir, Premier Balfour admitted, however, that "in these days of huge ships, there were difficulties in the way of examination of cargo which did not exist formerly; and this examination, though not forbidden by International Law, was made almost impossible by the difficulty of the operation." The right of visit and search must not be confounded with the right of capture, which is much less absolute and which is only justifiable under certain conditions which we need not here enumerate. Of course, the right of visit and search is also limited in several ways. In the first place, it is strictly a belligerent right, and unless there be a strong suspicion of piracy, it can not be exercised in time of peace, unless when permitted by treaty. In the second place, it is restricted in its application to merchantmen alone. In the third place, the right of search should be exercised in such a way as to cause the least possible inconvenience or injury to neu- 
structive (as in the case of enemy convoy), ${ }^{32}$ to the attempted exercise of this right entails condemnation and confiscation.

trals. In other words, as much regard should be paid as possible to the susceptibilities and interests of neutrals. On the limitations of the right of visit and search, see especially Woolsey, $\$ 208$, and Wharton's Dig. III, 8325 .

s2 See especially the cases of the Maria (1799), Robinson, 340; The Schooner Nancy (1812), 27 Court of Claims, 99; and The Ship Rose v. U.S. (190I), 36 Court of Claims, 29I ; also the dissenting opinion of Judge Story in the Nereide, 9 Cranch, 440; and the opinion (obiter dicta) of Justice Johnson in the case of the Atalanta, 3 Wheat. 424. The judges do not always distinguish clearly between neutral and enemy convoy.

In view of the suggestion which was made in some quarters that Great Britain send her merchant vessels to the Far East under convoy of her warships, it may be interesting in this connection to insert a brief discussion of the subject of convoy.

It is still a matter of controversy whether neutral merchantmen under convoy of warships of their own nation are bound to suffer visit and search. The English doctrine is best set forth by Lord Stowell in the case of the Maria, above cited. American jurists have generally followed the English decisions. In the case of the Nancy, it was held that the presence of an enemy convoy is constructive resistance and a denial of the right of search, which authorizes seizure and consequent condemnation. See also the dissenting opinion of Judge Story in the Nereide, 9 Cranch, 440. English and American writers are also generally agreed that "International Law does not prohibit search of convoyed vessels nor substitute the word of the commander for actual search." Dana's Wheaton, note 242, p. 695. Cf. Hall, \& 272; Lawrence, $\$ 268$; Kent, Com., Lect. VII, p. 154; Wheaton, Elem., \$\$ 525 ff; Phillimore, III, \& 338 . Woolsey appears to be alone in expressing the opinion that the right of convoy is destined to become a part of International Law.

Continental publicists are, on the other hand, almost unanimously in favor of exemption from search in the case of convoy by neutral warships. See, e. g., Bluntschli, \$\$ 824 and 826; Calvo, V, \$\$ $2969 \mathrm{ff}$, and the authorities there cited; Ortolan, Dip. de la Mer, liv. III, ch. 7; Hautefeuille, Droits des Neutres, Tit. XI, ch. 3 and Tit. XII, ch. I; Heffter, \& I70; Perels, Droit Maritime, \& 56; Bonfils, Manuel, \&\& 1597 1605; Dupuis, Le Droit de la Guerre Maritime, \$\$ 244-250; Kleen, II, pp. $346-390$.

Nearly all the maritime Powers of Europe have instructed their naval 
After this statement of the law and the facts so far as these can be ascertained, we must agree with the British Government that in respect to the Red Sea searches and seizures Russia was clearly guilty of a violation of "the public law of Europe" or of International Law. Either she violated a long line of solemn international compacts by sending commissioned warships through the Bosporus and the Dardanelles in the guise of merchantmen, or she violated one of the most cardinal principles of International Law by permitting or authorizing merchant vessels to exercise the strictly belligerent right of search on the high seas. If, e. g., the Peterburg was a lawfully commissioned warship, she had a perfect right to visit and search the Malacca on the Red Sea. This being the case, if it be true that the captain of the latter vessel refused to show the manifest of his cargo upon being requested to do so, the captain of the Peterburg was

commanders to respect the word of the commander of a convoy, and many of them have incorporated the principle of freedom from visit of ships under convoy into treaties. Great Britain, on the other hand, still maintains her old position of opposition to this innovation on the rights of belligerents, and has always refused to recognize this right, even in treaties.

The United States occupies a sort of intermediate position on this question. While her writers and jurists have, as a rule, sanctioned the English doctrine, the Government had accepted the principle of freedom from search under convoy in no less than thirteen treaties, mostly with American States, prior to 1872. (For list, see Hall, p. 729.) Article 30 of our Naval War Code, issued in 1900, declares that "convoys of neutral merchant vessels, under escort of vessels of war of their own state, are exempt from the right of search, upon proper assurances, based upon a thorough examination from the commander of the convoy." If the support or example of the British Government could be secured, the principle of freedom from search of vessels under convoy of ships of war of their own nation would, with certain restrictions, have an excellent chance of becoming incorporated among the unquestioned rules of International Law. For the present such a pretension must be denied. 
fully justified in assuming that she carried contraband, in seizing her as a prize of war, and in bringing her through the Suez Canal ${ }^{33}$ on his way to a Russian port. If, on the other hand, as seems more probable, ${ }^{34}$ the Peterburg was not a lawfully commisioned warship, the captain of the Malacca had a perfect right to refuse to show his manifest to the captain of what might, technically speaking, be regarded as a piratical vessel. In any case, whether the Peterburg was a lawfully commissioned warship or not, if, as claimed by him, the captain of the Malacca did not refuse to show his manifest and if the British Government stores on board the Malacca were mistaken for contraband, then the seizure was a serious mistake and a blunder for which the Russian Government owed ample amends and reparation to all concerned. ${ }^{35}$

${ }^{23}$ The fact that the Suez Canal is neutralized by an international treaty does not, as some have supposed, prevent its use by belligerents for the transportation of their prizes. See Articles IV and VI of the treaty, which is printed in Holland's Studies in International Law, pp. 289 ff.

${ }^{34}$ It is difficult to see how and where the Peterburg obtained her commission. She is said to have passed through the Straits as a merchantman on July 7, to have entered the Suez Canal on July 9, and was busy holding up neutral vessels on July II or 12. If she did not have a bona fide commission from the Russian Government, it is difficult to avoid the conclusion that, from a purely technical point of view, she was guilty of an act of piracy when she captured the Malacca. The Official Messenger of St. Petersburg stated on August 2, 1904, that the Peterburg and Smolensk had received a special commission, the term of which had expired. In that case they were undoubtedly warships, but as such they had no right to pass through the Straits.

It has been suggested that the Peterburg and Smolensk were privateers; but privateering was abolished by the Declaration of Paris in 1856 , to which Russia was a party, and it is not alleged that she possessed letters of marque. The least that can be said is that these vessels were guilty of acts of the grossest illegality.

${ }^{s}$ The real facts will probably never be fully known, both because the dispute was largely a political one and compromised on grounds of 
Another important question raised by these seizures is whether the right of search applies to neutral mail steamers. The law on this subject is by no means as clear as could be wished. The best rule is probably that laid down in the United States Naval War Code of 1900 : "A neutral vessel carrying hostile dispatches, when sailing as a dispatch vessel practically in the service of the enemy, is liable to seizure. Mail steamers under neutral flags carrying such dispatches in the regular and customary manner, either as a part of their mail in their mail bags, or separately as a matter of accommodation and without special arrangement or remuneration, are not liable to seizure, and should not be detained, except upon clear grounds of suspicion of a violation of the laws of war with respect to contraband, blockade, or unneutral service, in which case the mail bags must be forwarded with seals unbroken." ${ }_{36}$

Hostile dispatches, military orders, and the like (excepting diplomatic communications, which are privileged), ${ }^{37}$ are, of course, subject to capture, and the vessel carrying them, being engaged in an unneutral service, is liable to confiscation. $^{38}$ On the other hand, the owners and captains of neutral mail steamers, by virtue of the nature of the trust imposed upon them, can not be supposed to have knowledge of the contents of all the various communications entrusted to

policy, and because the examination of the cargo of the Malacca was a mere matter of form.

${ }^{38}$ Article 20 of Stockton's Code, p. 406 of Wilson and Tucker's International Law.

${ }^{37}$ See Lord Stowell's decision in the case of the Caroline, 6 Robinson 464.

${ }^{28}$ The cargo is also confiscated in cases where the "owners are directly involved in the knowledge and conduct of the guilty transaction." Lord Stowell in the case of the Atalanta, 6 Robinson 460. 
their charge. In recent times a usage ${ }^{30}$ has grown up in favor of exempting packet-boats, "not merely from condemnation, but also from visit, search, and capture." This immunity from search and capture has, however, been "granted by belligerents as a matter of grace and favor" rather than of law, and is by no means absolute or unlimited. $^{40}$

20 During the Mexican War, British mail-steamers were permitted to pass in and out of Vera Cruz. During our Civil War the British Government demanded that the United States should adopt the rule that "all mail bags, clearly certified as such, shall be exempt from seizure and violation." A few days later (October 3I, 1862), the United States Government issued instructions to the effect that "public mails of any friendly or neutral Power, duly certified or authenticated as such," found on board captured vessels, "shall not be searched or opened, but be put, as speedily as may be convenient, on the way to their designated destination. This instruction, however, will not be deemed to protect simulated mails verified by forged certificates or counterfeited seals." See Dana's Wheaton, note 228, pp. 659-60. For the diplomatic correspondence bearing on this subject, see Bernard, Neutrality, pp. 319-23. In 1870, France "insisted upon the condition that an agent of the neutral state should be in charge of the mail-bags and declare them to be free from noxious communications." Lawrence, Principles, p. 627. At the outbreak of the Spanish-American War in 1898, President McKinley declared that "the voyages of mail-steamers are not to be interfered with except on the clearest grounds of suspicion of a violation of law in respect to contraband or blockade." But the Spanish Government granted no such concession to neutrals. A similar indulgence to neutrals was granted by Great Britain during the Boer War in South Africa.

"On the other hand, many modern cases may be mentioned where no indulgence, or a very limited one, was given. For instance, in 1898 Spain did not duplicate the American concession, and in 1902 Great Britain and Germany would not allow neutral mail-steamers to pass through their blockade of Venezuelan ports, but stopped them instead, and, after overhauling their correspondence and detaining what seemed noxious, sent the rest ashore in boats belonging to the blockading squadron." Lawrence, War and Neutrality (2d ed.), p. I9I. It is, however, to be observed that this is a case of blockade, and has no bearing on the subject of search on the high seas.

${ }^{40}$ Lawrence, Principles, p. 627. Hall (3d ed., pp. 68I f) is of the opinion that mail-steamers, "although at present secure from condem- 
In view of the great variety in practice and uncertainty of the rule, it is highly desirable that this matter of the right of belligerent search of neutral mail steamers be referred for discussion and settlement to the next Hague Peace Conference, and that, in case of a dispute arising on this subject which can not be settled through the ordinary channels of diplomacy, it be referred to the Hague Tribunal for an authoritative decision. In the case of the Prinz Heinrich, it would appear that the German Government was correct in claiming that the Russians had no right to remove mail bags in a mass from the steamer. The Prinz Heinrich was, however, subject to visit and search if there was reasonable ground for suspicion of the presence of noxious dispatches, in which case the mails should have been opened in the presence of the ship's officers and the objectionable dis-

nation, are no more exempted than any other private ship from visit; nor does their own innocence protect their noxious contents, so that their post-bags may be seized on account of dispatches believed to be within them." But he thinks that "the secrecy and regularity of postal communication is now so necessary to the intercourse of nations, and the interests affected by every detention of a mail are so great, that the practical enforcement of belligerent rights would soon become intolerable to neutrals. . . . At the same time, it is impossible to overlook the fact that no national guarantee of the innocence of the contents of a mail can really be afforded by a neutral Power." He concludes: "Probably the best solution of the difficulty would be to concede immunity as a general rule to mail-bags, upon a declaration in writing being made by the agent of the neutral government on board that no dispatches are being carried by the enemy, but to permit a belligerent to examine the bag upon reasonable grounds of suspicion being specifically stated in writing." Taylor (Public International Law, \& 668, pp. 750-51) says: "The fact that the neutral carrier is permitted to convey certain classes of mail matter does not deprive the belligerent of the right to search his mail-bags in order to ascertain whether or no he is engaged in the transport of noxious dispatches." Oppenheim, the most recent authority on International Law (II, \$ 4II) leaves the question open. 
patches removed. The mail bags should then have been resealed and the vessel allowed to proceed on her voyage.

In respect to the question raised by the sinking of the Thea and the Knight Commander, the modern rule is reasonably clear, although it might be wished that some of the authorities $^{41}$ had made a clearer distinction between the rights of neutrals and belligerents in this matter. It is that

'The authorities are not fully agreed as to whether a neutral prize can ever be destroyed, but they all appear to limit the right, if it exists, to cases of extreme necessity. Hall (p. 74I) says emphatically: "A neutral vessel must not be destroyed." $\mathrm{He}$ observes that "the principle that destruction involves compensation was laid down in the broadest manner by Lord Stowell," who said that where a ship is neutral, "the act of destruction can not be justified to the neutral owner by the gravest importance of such an act to the public service of the captor's own state; to the neutral it can only be justified by a full restitution in value." See case of the Felicity, 2 Dodson 383.

Dana (see note 186 to Wheaton, p. 485) is of the opinion that "necessity will excuse the captor from the duty of sending in his prize. If the prize is unseaworthy for a voyage to the proper port, or where there is impending danger of immediate recapture from an enemy's vessel in sight, or if an infectious disease is on board, or other cause of a controlling character, the law of nations authorizes a destruction or abandonment of the prize, but requires all possible preservation of evidence, in the way of papers and persons on board. And, even if nothing of pecuniary value is saved, it is the right and duty of the captor to proceed for adjudication in such a case, for its own protection and that of his Government, and for the satisfaction of neutrals." Lawrence (Principles, p. 406), observes that "a broad line should be drawn between the destruction of enemy and neutral property,"-a distinction which Dana fails to make.

Taylor ( $\$ 557$, p. 573 ) says "it is generally agreed that neutral prizes should never be burned." He does not seem to contemplate the possibility of sinking them. Oppenheim ( $\$ 43$ I of Vol. II), as usual, leaves the question open.

For recent Continental opinions on the destruction of prizes, see especially Dupuis, Le Droit de la Guerre Maritime, \$\$ 26I ff; Kleen, De la Neutralite, pp. 529-534; Bonfils, Manuel, \& I4I5; Rivier, Principes, II, p. 350; Perels, Droit Maritime, p. 344; De Martens, Traité, III, p. 298. The Russian publicist De Martens enumerates five reasons which appear to him to justify the sinking of an enemy or neutral ship. 
neutral vessels or neutral cargoes must not be destroyed except in cases of extreme necessity, and that, in case of such necessity, the ship's papers must be preserved for purposes of adjudication and indemnification of the owners of the ship and cargo, who are entitled to full and adequate compensation for their losses. ${ }^{42}$ Prizes belonging to the enemy $^{43}$ may be destroyed for good military reasons, but the destruction of neutral property can only be justified on grounds of extreme necessity, since it involves the destruction of a part of the evidence on which alone the capture can

In two letters to the London Times for August 6 and August 30, 1904, Professor Holland thus summarizes the three leading English decisions on this subject: "Such action (i. e., the destruction of a neutral vessel by a captor) is justifiable only in cases of the gravest importance to the captors' own state, after securing the ship's papers and subject to the right of the neutral owner to receive full compensation." The decisions referred to are those of Lord Stowell in the cases of the Acteon (1815) and the Felicity (I8I9) in 2 Dodson 48 and $38 \mathrm{I}$; and the decision of Dr. Lushington in the case of the Leucade (1855), 2 Spinks 228.

Enemy prizes were systematically destroyed during the American Revolution and the War of I8I2. The destruction of enemy prizes by the Southern Confederacy has generally been justified on the ground that there were no non-blockaded ports to which they could be taken. Neutrals have nearly always, and enemies have generally, been exempt from such treatment. In 1870 the French burned two German vessels and refused indemnity in spite of the fact that they had neutral goods on board. Captain Semmes, of Alabama fame, who seems to have turned his cabin into a prize court, was in the habit of releasing ships whose cargoes were plainly neutral, on ransom. "But in a large number of the cases of those condemned and burned, there were claims for the cargoes as neutral property. Captain Semmes seems to have condemned the cargo, unless there was positive proof of its neutrality. This practice was carried on by him for four years, and was acquiesced in by neutral nations, who permitted their ships to be searched and their property adjudicated upon by these commanders." Snow's Cases, pp. 519-20. See also Scott's Cases, note on pp. 932-33. Cf. Bernard, Neutrality, p. 420 . 
be justified and inasmuch as neutral property does not vest in the captors until after it has been adjudicated upon.

It is true that the Russian Prize Regulations ${ }^{44}$ permit the destruction of prizes in a considerable number of contingencies, viz., unseaworthiness, danger of recapture, shortage of coal, difficulty on account of distance, and danger to the success of warlike operations. These are reasons which might perhaps justify the destruction of enemy prizes; but none of them seem sufficient to justify the destruction of neutral prizes, with the possible exception of unseaworthiness and danger of recapture. The Russian Regulations are plainly at variance with the rule of International Law, as stated above.

It is not alleged that the Knight Commander was unsea-

"For a reprint of the Russian "Prize Regulations," see House Doc. of 58th Congress (Foreign Relations-1904) pp. 736-54. On the destruction of prizes, see $\S 2$ I of the "Regulations" and $\S 40$ of the "Instructions," pp. 738 and 752. It should be noted that the "Project for the International Regulation of Maritime Prizes" adopted by the Institute of International Law in its sessions at Turin, Munich and Heidelberg ( $1882-1887$ ), from which the Russian Prize Regulations appear to be taken, merely authorize the sinking or burning of enemy ships. Tableau, \& 50, pp. 205-06. The Russian Regulations omit the word "enemy" before "prizes." Great Britain orders the release of a neutral ship in case of unseaworthiness or if a prize crew can not be spared. See Admiralty Manuel, p. 86. Our own Naval War Code (Art. 50) fails to make a distinction between neutral and enemy prizes. This is a dangerous error or omission which should be rectified in the next code.

The Japanese follow the English practice of releasing neutral vessels. The destruction of captured enemy ships is apparently permitted if the captor thinks that it is impossible to send the captured ship or its cargo to a Japanese prize court for adjudication or if there are an inșufficient number of sailors for this purpose. In such a case the commander is directed to conduct the vessel to the port nearest the place of capture and "act as the state of affairs permits." Article 20 of the Japanese Prize Regulations issued during the Chino-Japanese War of I894-5. See M. H. Nagaoka in Rez'ue Générale de Droit International Public for 1894, p. 504 . 
worthy or in imminent danger of recapture, or even that it was impossible to bring her into port. Still less was there an overpowering or extreme necessity for her destruction. It was not even vital to Russia's military interests that that portion of her cargo which consisted of railway material be destroyed or prevented from reaching its destination. Under the circumstances we must pronounce the sinking of the Knight Commander a gross and wanton attack upon neutral rights and an undoubted violation of International Law. 


\section{CHAPTER VI}

\section{Questions Relating to Contraband of War}

The Russo-Japanese War promises to mark an important epoch in the history of neutral rights and obligations, more particularly in definitely establishing the rights of neutral commerce in respect to that class of contraband goods characterized as articles ancipitis usus (double or dual use), and in extending the duties of neutral governments in limiting the use of neutral ports by belligerent armed vessels. ${ }^{1}$

On February 10, 1904, Japan published the following list of contraband articles, which are divided into two classes corresponding to the English and American division into absolute and conditional contraband :

I. Military weapons, ammunition, explosives and materials (including lead, salt-petre, sulphur, etc.), and machinery for making them, cement, uniforms (naval and military), military accoutrements, armour-plates, machinery and materials for construction or equipment of ships of war, and all other goods which, though not coming under this list, are intended solely for use in war. Above mentioned articles will be regarded as contraband of war when passing through or destined for enemy's army, navy or territory.

2. Provisions, drinks, horses, harness, fodder, vehicles, coal, timber, coins, gold and silver bullion and materials for construction of telegraphs, telephones and railways. Above mentioned articles will be regarded as contraband of war when destined for enemy's army or navy, or in such cases where, be-

${ }^{1}$ This latter subject will be discussed in the succeeding chapter. 
ing goods arriving at enemy's territory, there is reason to believe from the circumstances of the place of destination that they are intended for use of the naval or military forces of the enemy. ${ }^{2}$

It will be seen from the above list that Japan recognizes the English and American doctrine of Conditional Contraband, so emphatically but (so it seems to the writer) vainly denied or denounced by many Continental publicists. ${ }^{3}$

2 The italics are the author's. For this list see London Times (weekly ed.) for February 26, I904. See also Blue Book on Russia, No. I (I905), No. $I$ and inclosure in No. ro. For a translation differing slightly from the above, see House Doc. of 58th Congress (For. Rel., I904), p. 4I6. Cf. list published in Appendix VII of Takahashi's Cases on International Law during the Chino-Japanese War. See also lists found in the Manual of Naval Prize Law (p. 20), drawn up by Professor Holland of Oxford in 1888 for the use of the British Admiralty, and Art. I9 of the Instructions to Blockading Vessels and Cruisers, issued by the United States Government on June 20, 1898 . (See Appendix III in Snow's International Law. The list given in the Instructions has also been incorporated into Stockton's Naval War Code.) These lists, which are those of the leading modern maritime nations of the world who have the power to enforce their decrees, may be considered as the most authoritative. One looks in vain for agreement or consistency in treaties and amongst the authorities or publicists; but it is certainly fortunate that the leading maritime nations of the world (excepting France and Germany, perhaps), are in substantial agreement in regard to the question as to what articles may be dealt with as contraband of war. France can scarcely be cited any longer as favoring the restriction of contraband to arms and ammunition since her attempt to make rice absolute contraband in 1885 . In 1870 Germany remonstrated strongly with the English Government for permitting the export of coal to France. Russia protested vigorously against the inclusion of coal among the articles contraband of war during the West African Conference in 1884 .

'The English and American doctrine of conditional contraband is based upon the Grotian division of commodities into three classes: (I) articles of direct and immediate use in war, such as arms and ammunition, which are always contraband when they have a belligerent destination; (2) things absolutely useless in warfare, such as millinery and pianos, which are never contraband under any circumstances; (3) res ancipitis usus-things of double or dual use, $i$. e., equally useful in war or peace, such as coal, horses, provisions, cloth, etc. It is to this 
Russia, on the other hand, published on February 28, 1904, an extensive list of contraband, in which the distinc-

latter class that the English and American doctrine of conditional contraband has been applied, $i$. $e$, they are only to be considered contraband, and, therefore, as subject to preëmption or confiscation, when destined to a place besieged, or when clearly and unquestionably intended for the direct and immediate use of the army or navy of one of the belligerents. In any case, whether in the case of absolute or conditional contraband, a belligerent destination, either immediate or ultimate, is essential. It need not necessarily be a belligerent port. (See The Commercen, I Wheaton Rep. 382.) For leading cases on the doctrine of conditional or occasional contraband, see The Staat Embden (1798), I C. Robinson 26 (masts); The Endraught (I798), I C. Rob. 22 (timber); The Jonge Margaretha (1799), I C. Rob. I89 (cheese); The Jonge Tobias (I799), I C. Rob. 329 (tar) ; The Sarah Christina (I799), I C. Rob. 237, 24I (tar and pitch); The Ringende Jacob (1798), 3 C. Rob. 86 (hemp and iron bars); The Neptunus (I800), 3 C. Rob. 108 (sail cloth); The Edward (I80I), 4 C. Rob. 68 (wines); The Commercen (18I6), I Wheaton 382; The Ranger (1805), $6 \mathrm{C}$. Rob. 125 (provisions); and The Peterhoff (I866), 5 Wallace $28,58$.

The doctrine of conditional contraband is strongly opposed or denounced by many Continental publicists. Hautefeuille (Droits des Neutres, tit. VIII, sect. II, 3), who relies upon an imaginary loi primitive to prove his case, claims that contraband is confined to arms and munitions of war, or to articles expressly and uniquely destined for warlike use. (See also his Histoire du Droit Maritime, p. 433.) Ortolan (Dip. de la Mer, II, p. I90) is of the "opinion of those who think that the freedom of neutral commerce ought to furnish the general principle to which only such restrictions should be applied as are an immediate and necessary consequence of the state of war between the belligerents;" but he is willing, by way of exception, to make certain concessions to belligerents, "in view of some special circumstances affecting their military operations." Klüber ( $\$ 288$ ) also admits the existence of doubtful cases which must be governed by surrounding circumstances. Bluntschli ( $\$ 805$ ) admits that such objects as "clothing, money, horses, timber for naval construction, sail-cloth, iron plates, engines, coal, and merchant vessels" (he does not include food-stuffs in this list) may "exceptionally be regarded as contraband of war expressly sanctioned by treaty, or if, in a particular case, it can be shown that they are destined to be used in an existing war, and that they are carried to one of the belligerents with the intention of rendering him aid." (For criticism of the doctrine of intent of the owner as applied to contraband, see Kleen, 
tion between articles absolutely and conditionally contraband was ignored. This list was as follows :

I. Small arms of every kind, and guns, mounted or in sections, as well as armour-plates.

2. Ammunition for fire-arms, such as projectiles, shell-fuses,

Contrebande de guerre, pp. 37-43, and Thonier, Contrebande de guerre, pp. I47-149.)

Heffter ( $\$ 160)$ admits the existence of articles of occasional and conditional contraband "in treaties and in the special regulations of several countries," and adds that "a belligerent can only interfere with them when neutral trade, in conveying them to the enemy, affords to the latter succour of a manifestly hostile nature." The Russian De Martens (Traité, III, p. 351), who defines contraband as "objects which a neutral vessel is attempting to deliver (cherce à faire entrer) upon the territory of one of the belligerent states" (which objects, he declares, may always be seized), admits that those (objects) which are not of direct service in war may also be seized in exceptional cases according to the character and destination of the cargo and, in general, under certain determinate circumstances." Kleen (Contrebande de guerre, pp. I9 and 29) would limit the seizure and confiscation of articles as contraband of war to "munitions of war properly so called, i. e., objects expressly made for war or immediately and specially serviceable for warlike use in their actual state," and to "things which enter into the composition of such objects, if it be sufficient to reunite them or to place them into juxtaposition without any other labor, transformation or improvement." See also Kleen, Lois et Usages de la Neutralité, I, pp. $370 \mathrm{ff}$.

It will thus be seen that all of the Continental publicists cited above, with the exception of Hautefeuille and Kleen (the latter of whom seems to be the only thoroughly logical and consistent opponent of the doctrine of conditional contraband), practically concede the principle underlying the British and American contention, viz., that articles of dual or double use may, under certain circumstances (e.g., if destined for military use), be seized and confiscated as contraband of war. Their criticism seems in reality directed against some of the ways in which the doctrine has been applied by English and American prize courts rather than against the principle or doctrine in itself.

It should be noted that the Institute of International Law, in its session at Venice in I896, attempted to abolish what it called relative or accidental contraband as applied to articles ancipitis usus, and limited contraband of war to the following categories: (I) arms of every kind; (2) munitions of war and explosives; (3) military material such as ob- 
bullets, priming, cartridges, cartridge-cases, powder, salt-petre, sulphur.

3. Explosives and materials for causing explosions, such as torpedoes, dynamite, pyroxyline, various explosive substances, wire conductors, and everything used to explode mines and torpedoes.

4. Artillery, engineering, and camp equipment, such as gun carriages, ammunition wagons, boxes or packages of cartridges, field kitchens and forges, instrument wagons, pontoons, bridge trestles, barbed wire, harness, etc.

5. Articles of military equipment and clothing, such as bandoliers, cartridge-boxes, knap-sacks, straps, cuirasses, entrenching tools, drums, pots and pans, saddles, harness, completed parts of military uniforms, tents, etc.

6. Vessels bound for an enemy's port, even if under a neutral commercial flag, if it is apparent from their construction, interior fittings, and other indications that they have been built for warlike purposes, and are proceeding to an enemy's port in order to be sold or handed over to the enemy.

7. Boilers and every kind of naval machinery, mounted or unmounted.

8. Every kind of fuel, such as coal, naphtha, alcohol and other similar materials.

9. Articles and material for the installation of telegraphs, telephones, or for the construction of railroads.

Io. Generally, everything intended for warfare by sea or land, as well as rice, provisions, and horses, beasts of burden and others, which may be used for a warlike purpose, if they are transported on the account of, or are destined for, the enemy."

jects of equipment, uniforms, gun-carriages, etc.; (4) vessels equipped for war; (5) instruments especially made for the immediate manufacture of munitions of war. But the belligerent is permitted, at the risk of having to pay indemnity, to preëmpt or sequester objects which, taken on their way to an enemy port, may serve equally for warlike or pacific usage. See Annuaire, XVI, p. 205.

- The above version, which differs somewhat from that published in the United States, is the one given by T. J. Lawrence in his recent work, 
To this list raw cotton was added by Imperial Order on April 21, 1904.

War and Neutrality in the Far East, pp. 152-53. It may be found both in French and English in the Blue Book on Russia, No. I (1905), inclosure in No. 3. For the American translation, see House Doc. of 58th Congress, 3d session (Foreign Rel.-I904), p. 728.

The meaning of the words others and enemy in section ro is ambiguous. As Secretary Hay said in his Note of August 30, 1904, which contains the protest of the United States against the decision of the Russian prize court at Vladivostok in the case of the Arabia, to Mr. McCormick, our ambassador at St. Petersburg:

"The ambiguity of meaning which characterizes the language of this clause, lending itself to a double interpretation, left its real intendment doubtful. The vagueness of the language, used in so important a matter, where a just regard for the rights of neutral commerce required that it should be clear and explicit, could not fail to excite inquiry among American shippers, who, left in doubt as to the significance attributed by His Imperial Majesty's Government to the word 'enemy'-uncertain as to whether it meant 'enemy government or forces' or 'enemy ports or territory'-have been compelled to refuse the shipment of goods of any character to Japanese ports. The very obscurity of the terms used seemed to contain a destructive menace, even to legitimate American commerce.

"In the interpretation of this clause, and having regard to the traditional attitude of His Imperial Majesty's Government, as well as to the established rule of International Law, with respect to goods which a belligerent may or may not treat as contraband of war, it seemed to the Government of the United States incredible that the word autres (others), or the word l'ennemi (enemy), could be intended to include as contraband of war foodstuffs, fuel, cotton and all 'other' articles destined to Japanese ports, irrespective of the question whether they were intended for the support of a non-combatant population or for the use of the military or naval forces. In its circular of June ro last, communicated by you to the Russian Government, the department interpreted the word 'enemy' in a mitigated sense, as well as in accordance with the enlightened and humane principles of International Law, and, therefore, it treated the word 'enemy,' as used in the context, as meaning 'enemy government or forces,' and not the 'enemy ports or territory.'

"But if a benign interpretation was placed on the language used, it is because such an interpretation was due to the Russian Government, between whom and the United States a most valued and unbroken friendship has always existed, and it was no less due to the commerce of the latter, inasmuch as the broad interpretation of the language used would 
In the publication of this extensive list of articles (all of which were regarded as absolutely and unconditionally contraband), ${ }^{5}$ and still more by her subsequent conduct, Russia not only showed that she intended to ignore the doctrine of Conditional or Occasional Contraband, but she included in her list of things absolutely contraband many articles of ancipitis usus, such as coal, rice, horses, provisions, telegraph

imply a total inhibition of legitimate commerce between Japan and the United States, which it would be impossible for the latter to acquiesce in.

"Whatever doubt could exist as to the meaning of the Imperial Order has been apparently removed by the inclosure in your dispatch of the note from Count Lamsdorff, stating tersely and simply the sentence of the prize court. The communication of the decision was made in unqualified terms, and the department is, therefore, constrained to take notice of the principle on which the condemnation is based and which it is impossible for the United States to accept, as indicating either a principle of law or a policy which a belligerent State may lawfully enforce or pursue toward the United States as a neutral." See House Doc. cited above, pp. $76 \mathrm{I}-62$.

In a communication, dated March 7, 1904, addressed to Sir C. Scott, then the British Ambassador at St. Petersburg, Count Lamsdorff explained that section to meant "that the Imperial Government (of Russia) reserve to themselves the right to supplement the list of contraband articles by the addition of others if, in the circumstances of the war, they should judge it indispensable to forbid the conveyance of such articles to Japan or to Japanese armed forces." See Blue Book on Russia, op. cit., inclosure in No. 7. On March 19, 1904, the Journal of St. Petersburg published the following additional or supplementary instructions to commanders of Russian warships :

"Under the name of foodstuffs, to which allusion is made in section 10 of this Article, must be included among the number of articles which may be used for foodstuffs and forage for the Japanese army, all kinds of grain, fish, fish products of various kinds, beans, bean oil and oil cakes.

"On the list of articles intended for warlike purposes, either on land or on sea, should figure machinery and parts of machinery intended for the manufacture of cannon, small arms, and projectiles." See Blue Book cited above, p. 7.

- This was expressly so stated by Count Lamsdorff in the communication to Sir C. Scott above referred to. See Blue Book, op. cit., p. 6. 
and railway material, etc. These had always hitherto been regarded either as not contraband at all, or, if so, as subject to preëmption or confiscation only in certain contingencies or under certain circumstances, e. g., when destined to a place besieged, or when clearly and obviously intended for, or liable to fall into the possession of, the army or navy of the enemy. Russia will thus be seen to have gone farther than any belligerent has ever gone, at least since the time of the Napoleonic wars, in the direction of a real or threatened attack upon the rights and interests of neutral commerce. "The Russian Government, which more than a century ago was the foremost champion of the freedom of neutral commerce, put forth for, we believe, the first time in the history of civilized warfare the amazing pretension that all such goods should be considered contraband, regardless of destination or circumstances."

The publication of this list drew forth some severe criticism from the English and American Press, and what appears to have been an informal or semi-official protest from our State Department at Washington, ${ }^{\top}$ but it was not before the month of June, I904, that the American and British Governments took formal action. The British Government appears to have entered its first formal protest against Russia's inclusion of rice and other foodstuffs in her list of con-

- From an editorial in the New York Tribune for August 9, 1904

" "In regard to the Russian declaration of foodstuffs as contraband, it is said at the State Department that the destination of such goods must determine their character. If they are intended for either army they are contraband and subject to seizure. If they are intended for the use of civilians, except in the case of besieged towns, they must not be seized, or if seized, they must be paid for." See New York Times for March I, Ig04. 
traband early in June. ${ }^{8}$ On June 10, 1904, Secretary Hay sent the following Circular $^{\ominus}$ (which we reproduce in full because of its importance and because it serves to set forth the American position on the subject of contraband, together with the main arguments with which this view has been supported by one of our greatest statesman) to American ambassadors in Europe:

\section{Department of State,}

Washington, D. C., June Io, 1904.

To the Ambassadors of the United States in Europe:

GENTLEMEN-It appears from public documents that coal; naphtha, alcohol and other fuel have been declared contraband of war by the Russian Government.

These articles enter into general consumption in the arts of peace, to which they are vitally necessary. They are usually treated, not as "absolutely contraband of war," like articles that are intended primarily for military purposes in time of war, such as ordnance, arms, ammunition, etc., but rather as "conditional contraband," - that is to say, articles that may be used for or converted to the purposes of war or peace, according to circumstances. They may rather be classed with provisions and foodstuffs of ordinarily innocent use, but which may become absolutely contraband of war when actually and especially destined for the military or naval forces of the enemy.

In the war between the United States and Spain the Navy Department, General Orders, No. 492, issued June 20, I898, declared, in Article 19, as follows: "The term contraband of war comprehends only articles having a belligerent destination." Among articles absolutely contraband it declared ordnance, machine guns and other articles of military or naval warfare. It declared as conditional contraband "coal, when destined for

'See the Marquess of Lansdowne to Sir C. Hardinge in Blue Book on Russia, op. cit., No. I6.

- See House Doc., op. cit., pp. 3-4 and pp. 730-32. The British protest was directed mainly against the inclusion of foodstuffs as contraband, whereas Secretary Hay confined himself mainly to coal and cotton. 
a naval station, a port of call, or a ship or ships of the enemy." It likewise declared provisions to be conditionally contraband "when destined for the enemy's ship or ships, or for a place that is besieged."

The above rules as to articles absolutely or conditionally contraband of war were adopted in the Naval War Code, promulgated by the Navy Department, June 27, 1900.

While it appears from the documents mentioned that rice, foodstuffs, horses, beasts of burden, and other animals which may be used in time of war are declared to be contraband of war only when they are transported for account of or in destination to the enemy, yet all kinds of fuel, such as coal, naphtha, alcohol, are classified along with arms, ammunition and other articles intended for warfare on land or sea.

The test in determining whether articles ancipitis usus are contraband of war is their destination for the military uses of a belligerent. Mr. Dana, in his notes to Wheaton's International Law, says: "The chief circumstance of inquiry would naturally be the port of destination. If that is a naval arsenal, or a port in which vessels of war are usually fitted out, or in which a fleet is lying, or a garrison town, or a place from which a military expedition is fitting out, the presumption of military use would be raised, more or less strongly, according to circumstances."

In the wars of 1859 and I870 coal was declared by France not to be contraband. During the latter war Great Britain held that the character of coal depended upon its destination, and refused to permit vessels to sail with it to the French fleet in the North Sea. Where coal or other fuel is shipped to a port of a belligerent, with no presumption against its pacific use, to condemn it as absolutely contraband would seem to be an extreme measure.

Mr. Hall, Internationual Law, says: "During the West African Conference in I884, Russia took occasion to dissent vigorously from the inclusion of coal amongst articles of contraband of war, and declared that she would categorically refuse her consent to any articles in any treaty, convention, or instrument whatever, which would imply its recognition as such." 
We are also informed that it is intended to treat raw cotton as contraband of war. While it is true raw cotton could be made up into clothing for the military uses of a belligerent, a military use for the supply of an army or garrison might possibly be made of foodstuffs of every description which might be shipped from neutral ports to the non-blockaded ports of a belligerent. The principle under consideration might, therefore, be extended so as to apply to every article of human use which might be declared contraband of war simply because it might ultimately become in any degree useful to a belligerent for military purposes.

Coal and other fuel and cotton are employed for a great many innocent purposes. Many nations are dependent on them for the conduct of inoffensive industries, and no sufficient presumption of an intended warlike use seems to be afforded by the mere fact of their destination to a belligerent port. The recognition, in principle, of the treatment of coal and other fuel and raw cotton as absolutely contraband of war might ultimately lead to a total inhibition of the sale, by neutrals to the people of belligerent states, of all articles which could be finally converted to military uses. Such an extension of the principle by treating coal and all other fuel and raw cotton as absolutely contraband of war, simply because they are shipped by a neutral to a non-blockaded port of a belligerent, would not appear to be in accord with the reasonable and lawful rights of a neutral commerce. I am, gentlemen, etc.,

JoHN HAY. ${ }^{10}$

Fortunately for Russia and the neutral nations, the Russians had no opportunity of making a practical application of their extraordinary views on the subject of contraband until the months of June and July, I904, ${ }^{11}$ when the Vladi-

\footnotetext{
${ }^{10}$ In the comments of the British and American newspapers (including those of the political opponents of the Administration) upon the position taken by Secretary Hay in this circular, we have been unable to detect a single dissenting voice amidst the general chorus of approval.

${ }^{11}$ As has been noted in the previous chapter, the neutral colliers
} 
vostok squadron captured several neutral vessels in the $\mathrm{Pa}$ cific, and they desisted from attempting to enforce these views a few months later. The first case which aroused controversy was that of the British collier Allanton, which was captured on June 16, I904, in the straits of Korea on her return voyage from a Japanese port, while conveying Japanese commercial (anthracite) coal from Japan to Singapore. One of the grounds on which the vessel was condemned by the Vladivostok Prize Court, on June 24, was that she had carried contraband (Welsh) coal to Japan on her outward voyage. The British Government refused to interfere at the time on the ground that, inasmuch as an appeal to the Admiralty Council at St. Petersburg had been allowed, the case was still sub judice. ${ }^{12}$ The Allanton was subsequently released by the Admiralty Council at St. Petersburg.

If the facts alleged by those interested in the fate of the Allanton are correct, there can be no question but that the

seized and detained as prizes in the Red Sea during the second week of the war were released in response to an order of the Czar on the ground that these captures had been made before the formal declaration of coal as contraband of war. The later Red Sea seizures were decided on other grounds than that of their alleged carriage of contraband.

${ }^{12}$ On the Allanton case, see especially a letter by W. R. Rea, the owner of the Allanton, in the London Times (weekly ed.) for Sept. 2, 1904, and the letter from the British Foreign Office to Mr. Stanley Mitcalfe in the London Times (weekly) for August 26, 1904. Some of the grounds given by the Russians for the condemnation of the vessel were very trivial, as, $e$. g., that she had a Japanese cabin boy on board, that the official log-book had not been entered up properly, etc. A more serious charge was that her papers were irregular. The Allanton was released by the Admiralty Court of St. Petersburg on October 22, 1904. For a very full and comprehensive review of this case, see Lawrence, War and Neutrality, pp. 221-247. Cf. Smith and Sibley, cited below, App. F. 
Russian Prize Court at Vladivostok was guilty of a serious violation of the law of contraband in condemning the vessel for an offense supposed to have been committed on her outward voyage. As Lord Stowell said in the case of the Imina (3 Rob. 168), "the articles must be taken in delicto, in the actual prosecution of the voyage to an enemy's port. ${ }^{18}$ Under the present understanding of the law of nations you can not generally take the proceeds on the return journey." 14

${ }^{13}$ This is the general rule, but there are exceptions. In 1816 the cargo of the Commercen, a Swedish vessel, was condemned by the Supreme Court of the United States because it was intended for the British fleet lying in a Spanish port during the War of 1812. The cases to which the doctrine of continuous voyage has been applied may also be said to constitute exceptions to this rule. In any case, the real or ultimate destination must be a hostile one. The case of the Allanton can not be brought under any of these heads. Her destination appears to have been really as well as nominally neutral. Smith and Sibley (International Law as Interpreted during the Russo-Japanese War, pp. $334 \mathrm{ff}$.) treat the decision in the case of the Allanton as "an extension of the doctrine of continuous voyage." This, like much else in that bulky and pretentious volume, is absurd as well as erroneous.

${ }^{14}$ The rule is different in the case of an attempted breach of blockade, in which case the outward and return voyages are regarded as parts of one transaction and the offence clings to the blockade runner during the return voyage. See Lord Stowell's decision in the case of the Juffrow Maria Shroeder, 3 Rob. I53. But in the case of contraband the return voyage is regarded as a separate and, therefore, innocent expedition. In the case of the Nancy ( 3 Rob. 127), Lord Stowell held that the return voyage will not be regarded as a separate and innocent expedition if the "outward and homeward voyages are but parts of one transaction, conducted by the same persons and planned from the beginning as one adventure, and if on the outward voyage contraband goods and fraudulent papers are carried." Cited by Lawrence, Principles, p. 6r6. But, as Lawrence says, "it is somewhat doubtful whether this view would be acted upon at the present time. Continental publicists condemn it as an undue extension of belligerent rights, and the British Admiralty Manual contents itself with the statement that a commander should detain a vessel he meets on her return voyage with such a record as we have described behind her." See Holland's Manual, pp. 23-24. 
The most important cases bearing on the subject of contraband which arose during the war were those of the Knight Commander, ${ }^{15}$ the Arabia, and the Calchas-all of which were cases of prizes captured by the Vladivostok squadron in the latter part of July, r904.

The Knight Commander was a British steamer with a

${ }^{15}$ The German steamer Thea, which was sunk by the Vladivostok fleet at about the same time as the Knight Commander, is omitted because no facts have come to light which would make a discussion of this case profitable or even possible.

No question appears to have been raised regarding the legality of the capture of the British steamer Cheltenham early in July, r904, until the appearance of Smith and Sibley's work, above referred to (see Appendix E, pp. $435 \mathrm{ff}$.). These authors urge that the condemnation of this vessel, together with its cargo, by the Russian Prize Court at Vladivostok-a decision upheld by the Supreme Naval Court at St. Petersburg-was illegal inasmuch as it "involves the condemnation of both ship and cargo for conveying conditional contraband to a port which can not fairly be considered belligerent." The main part of the cargo of the Cheltenham consisted of railway sleepers and construction timber which were being conveyed from Otarn, Japan, to Fusan, Korea, for the Seoul-Fusan Railway, then being used for military purposes by the Japanese Government. The Insurance Correspondent of the London Times (see weekly edition for July 8, I904, p. 440) says: "Unlike the case of the Allanton, I am afraid there can be no disputing the legitimacy of this capture." It appears that this was the fourth time this vessel had conveyed railway material from Japan to the seat of war. In a suit for compensation brought against her owners by I9 of the crew of the Cheltenham (see London Times, weekly, for September 16, 1904, p. 607), the attorney for the defence himself admitted that his "clients were trading between Japan and Korea in what was declared by both Russia and Japan to be contraband of war." One is pleased to note that his clients lost their case. See London Times for September 23, p. 622. And yet the writers cited above claim that "the two indissoluble tests of contraband, hostile quality and hostile destination, seem alike absent in the case of the Cheltenham." This vessel was, indeed, guilty of a much more serious offence against belligerent rights than is involved in the carriage of contrabandshe was engaged in unneutral service and deserved the full penalty of the law. The argument that, inasmuch as Russia was not at war with Korea, Fusan was therefore a neutral port, is puerile. 
general cargo (including flour and railway material) from New York consigned to various Eastern ports, viz., Manila; Shanghai and Yokohama. She was sunk by the Vladivostok fleet and afterward condemned by a Russian prize court. The questions involved in her destruction as a neutral prize have been discussed in the preceding chapter. Our conclusion was that there existed, under the circumstances, no justification for her destruction, even if she carried contraband. The British Government received an indemnity for the destruction of the vessel, but we have not heard that the American owners of the cargo were in any way compensated for any losses they may have sustained. It would seem that they were entitled to compensation or restitution even in the case of such portion of the cargo as consisted of contraband, inasmuch as it was illegally destroyed before the condemnation by a properly constituted prize court. ${ }^{16}$

The cases of the Arabia and Calchas may conveniently be considered in connection with each other, inasmuch as the circumstanes of these cases are practically identical and the

${ }^{18}$ But a Reuter's telegram to London, dated August 9, declared that "no proof of the American ownership of a single pound of the Knight Commander's cargo had been produced at the State Department." Cited by Lawrence, War and Neutrality, p. 25I. The United States Government entered a conditional protest, on July 30, 1904, against the destruction of any American property which might be found on board the vessel. (See House Doc., op. cit., p. 734.) In view of the subsequent silence of our State Department, it may be assumed that the information contained in Reuter's dispatch, referred to above, was correct.

It was reported at the trial that a letter book, which was found in the captain's cabin, contained copies of correspondence, proving that the cargo (probably the railway material) on board the Knight Commander was really destined for Chemulpo. In that case, its confiscation as contraband of war by a prize court would have been entirely justifiable. See London Times (weekly ed.) for August 12, 1904. 
principle governing them is the same. The Arabia was a German vessel with a cargo composed of American flour, machinery and railway material consigned mainly to Hong Kong $^{\mathbf{1 7}}$ and Japanese ports. There appears to have been no evidence that either the flour or the railway material was intended for the use of the Japanese Government. ${ }^{18}$ The cargo was shipped in the ordinary course of trade from Portland, Oregon, and was in part consigned to commercial

${ }^{17}$ The Arabia appears, at the time of her seizure on July 22, I904, to have been on her way to the neutral port of Hong Kong, but this fact would by no means have saved her cargo from condemnation if it could have been shown that her real or ultimate destination was a belligerent one. The doctrine of continuous voyage has, however, no applicability to this case, and strangely enough, no case calling for its application seems to have arisen during the war. The doctrine is undoubtedly sound in principle, although liable to great abuse in practice.

The doctrine of continuous voyage was first applied to contraband by a French prize court (in the case of the Vrou Hourvina) during the Crimean War in 1855 , but it did not attract general attention until the extension and publicity given to the doctrine by the decisions of the Supreme Court of the United States (in cases of the Peterhoff, etc.), at the close of the Civil War. The doctrine in question was approved by the Italian Council of Prizes in 1896 (in the case of the Doelroyk) and was sanctioned by the Institute of International Law at its session in Venice the same year. The attempt of England to enforce the doctrine (in the cases of the Bundesrath, etc.) during the Boer War in 1900 failed, however, owing to the determined opposition of Germany. On "Continuous Voyage as Applied to Contraband," see especially Westlake in Law Quarterly Review, XV, pp. 24-32; Woolsey in Outlook, Vol. 94, pp. I67 ff; and Baty, International Lawe in South Africa, ch. I. The latter is an extremely able attack on the doctrine. Mr. Baty, at least, shows that it is liable to great abuse. The doctrine is generally condemned by Continental authorities.

${ }^{18}$ It was claimed at the time that the railway material, although primarily to be landed at a Japanese port, was to be transhipped thence to Chemulpo in Korea, where it was to be used in the construction of a railway by the Japanese Government; but none of the cargo appears to have been condemned on this ground. 
houses in Hong Kong, Yokohama and other Chinese and Japanese ports.

The United States Government at once asked for the release of the vessel and its cargo, ${ }^{19}$ but the Russian Prize Court at Vladivostok, which gave its decision in the latter part of July, I904, condemned such portions of the cargo (flour and railway material) of the Arabia as had been consigned to Japanese ports. The vessel, together with the remainder of the cargo (which consisted of flour consigned to neutral ports, and which included more than one-half of its bulk and weight) was released. ${ }^{20}$

The Calchas was a British steamer, largely, if not entirely, laden with an American cargo of flour, raw cotton, lumber, machinery, etc., ${ }^{21}$ shipped from Tacoma and consigned to various Eastern and European ports. As in the case of the Arabia, it was claimed by the owners of the cargo ${ }^{22}$ that the commodities shipped to Japanese ports were consigned to various commercial houses, and that they were in no wise intended for the consumption of the Japanese army or navy. The decision of the local Russian Prize Court at Vladivostok $^{23}$ was the same as in the case of the Arabia. The ves-

${ }^{10}$ House Doc., cited above, p. 735.

${ }^{20}$ See New York Times for August 4, 1904. For the decision, as given by Count Lamsdorff to Mr. McCormick, see House Doc., op. cit., p. 756. The cargo was condemned on the ground that it was "bound for Japanese ports and addressed to various commercial houses in said ports."

${ }^{21}$ The cotton and machinery are said to have been of a strictly commercial character.

${ }^{2}$ See letter of A. Holt and Company in London Times (weekly) for August 26, 1904 .

${ }^{23}$ See New York Times for September 15, 1904, and House Doc., cited above, p. 765. The Calchas was captured in the latter part of July and arrived at Vladivostok on August 8, but the decision of the prize court was not rendered before September 13, 1904.

The Calchas was, however, detained at Vladivostok until October 28, 
sel, together with that part of the cargo consigned to neutral ports, was finally released after a detention of several months, but that portion of the cargo which had been consigned to Japanese ports was condemned. In both of these cases an appeal was taken to the higher Admiralty Court at St. Petersburg. This court happily reversed the decision of the lower prize court in the case of the Arabia (in December,

i. e., a month and a half after she should have been released, on the plea of the Russian Crown Advocate that she had carried mail matter from the United States to Japan containing financial information of special value to the enemy addressed to Japanese officials. This fact was not made public until October 9, when it was learned that several of the Pacific mail steamship lines had notified the Postmaster-General at Washington that they would thereafter refuse to carry United States mail addressed to Japan. It was subsequently learned that the mail bags of the Calchas had been opened by Russian officials and that the contents of four registered mail sacks had not only been opened, but removed. The bags were then resealed and forwarded to Japan after considerable delay. Among the letters lost are said to have been some diplomatic communications (which are privileged) from the Japanese Minister at Washington. It was also reported on October $\mathrm{I}_{4}$ that a pouch containing private or domestic mail for the United States cruiser Cincinnati, then at Nagasaki, Japan, had been opened, subsequently resealed, and then sent on to its destination. On October 13 and 17 , I904, Secretary Hay instructed our representative at St. Petersburg to bring these instances "of what appear to be a violation of the Universal Postal Convention to the attention of the Russian Government, and to request of it an investigation and appropriate action." Mr. Hay added: "Any interruption of regular postal communication entails such serious inconvenience to various interests that, apart from the provisions of treaty, a usage has grown up to exempt neutral mails from search or seizure." House Doc., op cit., p. 772. We are not informed as to the action of the Russian Government in the matter.

If the facts were correctly stated, there can be no doubt that the Russian authorities were guilty of a clear violation of the International Postal Union Treaty, as well as of International Law. However far the belligerent right of search of neutral mail steamers and confiscation of noxious mail matter may extend, it can not possibly be made to justify the detention of a mail steamer under such circumstances. The law bearing on this subject has already been discussed in the preceding chapter. 
I904) ; but decided to confiscate certain portions of the cargo of the Calchas, to inquire into the destination of other portions, and to release the vessel and the remainder of the cargo. The seizure itself was declared to have been justified. This court, of which the eminent Russian publicist De Martens was a member, pronounced cotton contraband of war. ${ }^{24}$

The only attempted justification of the decisions of the Prize Court at Vladivostok which we have seen is the following semi-official statement by a high Russian official to the Associated Press :

"Foodstuff consigned to an enemy's port in sufficient quantity to create the presumption that it is intended for the use of the Government's military or naval forces is prima facie contraband and sufficient to warrant holding it for the decision of a prize court. Even if consigned to private firms, the burden of proof that it is not intended for the Government rests upon the consignor and consignee. If it can be proved that it is not intended for non-combatants it will not be confiscated. Small consignments of foodstuff in mixed cargoes will be considered presumptively to be regular trade shipments, and will not be seized as contraband." 25

On August I0, I904, the British Government addressed a strongly-worded protest $^{26}$ to the Russian Government against the Russian view of contraband, as also against the sinking of neutral merchantmen by Russian warships. ${ }^{27}$ In respect to contraband, Lord Lansdowne pointed out the dis-

${ }^{24}$ See London Times (weekly ed.) for May 20, 1905.

${ }^{25}$ See the New York Times for August 7, 1904.

${ }^{26}$ This protest was not presented to the Russian Government before August I6.

${ }^{27}$ See Nos. 20 and 21 in Blue Book on Russia, op. cit. 
tinction between conditional and absolute contraband, and "with regard to foodstuffs consigned to a belligerent's port," he maintained that "proof is necessary that the goods are intended for the belligerent's naval or military forces before they can be considered as contraband." 28

On August II, and again on August $30,1904,{ }^{29}$ the United States Government protested vigorously against the confiscation of American flour and railway material on board the Arabia. In his famous Note of August 30, Secretary Hay, after remarking that the "judgment of confiscation appears to be founded on the mere fact that the goods in question were bound for Japanese ports and addressed to various commercial houses in said ports," observed that "in view of its well-known attitude, it should hardly seem necessary to say that the Government of the United States is unable to admit the validity of the judgment, which appears to have been rendered in disregard of the settled law of nations in respect to what constitutes contraband of war."

After calling attention to the ambiguity of the Russian Imperial Order of February 28, in respect to the words "enemy" and "others," "30 Mr. Hay thus explained the attitude of the United States in respect to telegraphic, telephonic and railway material:

"With respect to articles and material for telegraphic and

${ }^{28}$ See London Times (weekly ed.) for August 26, 1904. The British position in respect to foodstuffs was thus stated by Lord Salisbury at the beginning of the Boer War: "Foodstuffs with a hostile destination can be considered contraband of war only if they are supplied for the enemy's forces. It is not sufficient that they are capable of being so used; it must be shown that this was, in fact, their destination at the time of seizure."

${ }^{20}$ For these protests, see House Doc., op. cit., pp. 756-57, and pp. $760-63$.

${ }^{30}$ See supra, note on p. 165 . 
telephonic installations, umnecessary hardship is imposed by treating them all as contraband of war-even those articles which are evidently and unquestionably intended for merely domestic or industrial uses. With respect to railway materials, the judgment of the court appears to proceed in plain violation of the terms of the Imperial order, according to which they are to be deemed to be contraband of war only if intended for the construction of railways. The United States Government regrets that it could not concede that telegraphic, telephonic and railway materials are confiscable simply because destined to the open commercial ports of a belligerent."

This great master of International Law and Diplomacy then proceeded to furnish an explanation of the nature of contraband, which we may accept as authoritative:

"When war exists between powerful states it is vital to the legitimate maritime commerce of neutral states that there be no relaxation of the rule-no deviation from the criterion for determining what constitutes contraband of war, lawfully subject to belligerent capture, namely, warlike nature, use and destination. Articles which, like arms and ammunition, are by their nature of self-evident warlike use, are contraband of war if destined to enemy territory; but articles which, like coal, cotton and provisions, though of ordinarily innocent, are capable of warlike use, are not subject to capture and confiscation unless shown by evidence to be actually destined for the military or naval forces of a belligerent.

"This substantive principle of the law of nations can not be overridden by a technical rule of the prize court that the owners of the captured cargo must prove that no part of it may eventually come to the hands of the enemy forces. The proof is of an impossible nature and it can not be admitted that the absence of proof, in its nature impossible to make, can justify the seizure and condemnation. If it were otherwise, all neutral commerce with the people of a belligerent state would be impossible; the innocent would suffer inevitable condemnation with the guilty. 
"The established principle of discrimination between contraband and non-contraband goods admits of no relaxation or refinement. It must be either inflexibly adhered to or abandoned by all nations. There is and can be no middle ground. The criterion of warlike usefulness and destination has been adopted by the common consent of civilized nations, after centuries of struggle, in which each belligerent made indiscriminate warfare upon all commerce of all neutral states with the people of the other belligerent, and which led to reprisals as the mildest available remedy."

The logical results of the new Russian doctrine were thus summarized :

"If the principle which appears to have been declared by the Vladivostok Prize Court and which has not so far been disavowed or explained by his Imperial Majesty's Government is acquiesced in, it means, if carried into full execution, the complete destruction of all neutral commerce with the noncombatant population of Japan; it obviates the necessity of blockades; it renders meaningless the principle of the declaration of Paris set forth in the Imperial Order of February 29 last, that a blockade in order to be obligatory must be effective; it obliterates all distinction between commerce in contraband and non-contraband goods; and is in effect a declaration of war against commerce of every description between the people of a neutral and those of a belligerent state."

And he closes with the following protest on the part of the United States:

"You will express to Count Lamsdorff the deep regret and grave concern with which the Government of the United States has received his unqualified communication of the decision of the prize court; you will make earnest protest against it and say that the Government of the United States regrets its complete inability to recognize the principle of that decision, and still less to acquiesce in it as a policy." 31

"21 The Hay Note or protest of August 30, 1904, will undoubtedly take 
In his verbal reply of September 16 to the British protest of August 10, Count Lamsdorff informed Sir Charles Hardinge that, "owing to the decision of a Commission which had been formed under the Presidency of Professor Martens to study the question of contraband, supplementary instructions $^{32}$ had been issued to the Naval Commanders and to the Naval Prize Courts defining the interpretation of section Io of Article 6 of the Russian Rules, which the Commission were of the opinion had in some cases been misinterpreted. According to the instructions now issued, the conditionally contraband nature of articles used for peaceful or warlike purposes, according to circumstances and included under section Io of Article 6, was admitted, but the Russian Government could not admit that articles of dual use when addressed to private individuals in the enemy's country should necessarily be free from seizure and condemnation, since provisions and such articles of dual use, though intended for the military or naval forces of the enemy, would obviously, under such circumstances, be addressed to private individuals and not to the government, thus defeating the object of the Regulations." 33 Count Lamsdorff assented to the proposition made by the British ambassador that "in the event of the seizure of articles of a conditionally contraband nature addressed to private individuals, the burden of proof would necessarily rest with the captor." 34

rank as one of the best and most authoritative utterances on the law of contraband.

"For the text of these instructions, as amended at the request of the British Government, see Blue Book, cited above, No. 39 (inclosures).

"Blue Book on Russia, cited above. Sir Charles Hardinge to the Marquess of Lansdowne, Nos. 29 and 30 . Cf. Mr. McCormick to Mr. Hay on September 21, 1904, in House Doc., op. cit., pp. 767-68.

"Ibid. The italics are the writer's. But Count Lamsdorff observed 
It will thus be seen that Russia admitted the principle of Conditional Contraband, but restricted its application to the articles enumerated in section ro, $i$. e., practically to rice and other provisions; for horses and beasts of burden were expressly exempted from the operation of the rule, $i$. e., they were declared to be absolutely contraband. In view of this limitation, Sir Charles Hardinge, acting upon instructions from the British Government, made further representations to the Russian Government against the treatment of such articles as coal and raw cotton as contraband, ${ }^{35}$ but was unable to obtain specific assurances on these points. ${ }^{36}$

Another question relating to the law of contraband, which can hardly be said to be more than academic in its nature, arose during the war. The Russians appear to have challenged the legality or legitimacy of trade in contraband itself.

An Associated Press dispatch of July 30, I904, stated that Russia had filed a formal protest at the British Foreign office against the British shipments of contraband of war to

that "it would be equally to the advantage of the owner of the articles in question to disprove the charge that they were destined for the military or naval forces of the enemy."

"See Blue Book, op. cit., Nos. 33, 37 (inclosure), 38 (inclosure). $C f$. official letter to the Liverpool Chamber of Commerce published in the London Times for November 28, 1904.

* The British ambassador was assured.by Count Lamsdorff that "the new instructions had been drawn up in a sense to avoid future difficulties with neutral Powers," and that "he (Count Lamsdorff) was confident that, by a liberal construction, they might be made to cover not only the articles mentioned in section Io, but also those enumerated in the preceding sections." He pointed out that "even in cases where the decision of the Court of Appeal might prove unsatisfactory to a foreign government, there was always arbitration or some such measure to which recourse could be finally had." Sir Charles Hardinge to the Marquess of Lansdowne, September 21, 1904. Blue Book, op. cit., No. 33. 
Japan. It was further asserted that the Russian Government had carefully watched the manufacture of goods intended for the use of the Japanese Government; that as soon as it was established that such goods were about to be shipped to a hostile destination, the facts were officially communicated to the British Government, with a request that measures be taken to stop the shipments; and that at the close of the war Russia proposed to present a bill for damages to the British Government as an offset to the indemnities claimed by the latter for the seizure of the British steamers. ${ }^{37}$

Similar protests are heard in nearly every war. ${ }^{38}$ "Whenever a trade in contraband of war reaches large dimensions, the state whose adversary is supplied by means of it is apt to complain. It reproaches the government of the offending vendors with neglect of the duties of neutrality, and argues that friendship and impartiality alike demand the stoppage of a traffic which supplies its foe with the sinews of war. But it invariably receives in reply a reminder that the practice of nations imposes no such obligation upon neutral powers. . . The utmost that can be expected of them in the matter of ordinary business transactions is that they shall warn their subjects of the risks run by carriers of contraband merchandise, and give notice that those who incur them will not be protected by the force or the influence of the state."

${ }^{37}$ N. Y. Times for July $30,1904$.

${ }^{38} E$. g., Bismarck denounced in vigorous language the conduct of the British authorities in allowing the sale by English firms to France of arms and ammunition in 1870 , and the United States complained of the refusal of the British Government to put a stop to the trade in contraband goods between Great Britain and the ports of the Southern Confederacy during the Civil War.

${ }^{30}$ Lawrence, Principles, pp. 599-600. It may be doubted whether even 
The American position on this question was thus stated by Jefferson in I793, when Great Britain complained of the sale in the United States of arms and accoutrements to an agent of the French government: "Our citizens have always been free to make, vend and export arms. It is the constant occupation and livelihood of some of them. To suppress their callings, the only means, perhaps, of their subsistence, because a war exists in foreign and distant countries, in which we have no concern, would scarcely be ex-

this much is obligatory. Only a few of the Neutrality Proclamations, e. g., those of Great Britain and the United States, contain such warning or notice. The language of the British Proclamation declaring that any one engaging in the carriage of contraband "will rightfully incur and be justly liable to hostile capture and the penalties denounced by the law of nations in that behalf," and that they "will in no wise obtain protection from us against such capture or such penalties," is characterized as "misleading rhetoric" by Professor Holland in his letter to the London Times for November 29, 1904. It may be observed that the language of the United States Proclamation is less strong. It merely states that "while all persons may lawfully, and without restriction manufacture and sell within the United States, arms and ammunition of war, and other articles ordinarily known as 'contraband of war' yet they can not carry such articles upon the high seas for the use or service of either belligerent . . . without incurring the risk of hostile capture and the penalties denounced by the law of nations in that behalf."

It is interesting in this connection to note that the Chinese "Neutrality Regulations" (Art. 6) actually forbid the purchase and manufacture of contraband of war within neutral territory for the use of or sale to the belligerents. The "Royal Proclamation" relative to the neutrality of Denmark (Paragraph 6, section 4) forbids Danish subjects to supply belligerent ships with "articles that are considered contraband," and the "Notice to Danish Trade and Shipping" (Art. 3) forbids any owner or master of a Danish vessel "to employ his ship in the transporting of troops or contraband of war for any of the belligerent powers, or to let or charter ships which are known or supposed to be destined for such purpose." The Brazilian Neutrality Proclamation, issued in I898 (IV), "absolutely" prohibits "the exportation of material of war from the ports of Brazil to those of either of the belligerent powers under the Brazilian flag, or that of any other nation." 
pected. It would be hard in principle and impossible in practice. The law of nations, therefore, respecting the rights of those at peace, does not require from them such an internal derangement in their occupations. It is satisfied with the external penalty pronounced in the President's proclamation, that of confiscation of such portion of these arms as shall fall into the hands of the belligerent powers on their way to the ports of their enemies. To this penalty our citizens are warned that they will be abandoned." A little later in the same year ( 1793 ) Hamilton also declared that "the purchasing within and exporting from the United States, by way of merchandise, articles commonly called contraband is free to all the parties of the war, and is not to be interfered with." 40

These expressions of opinion on the part of two of the greatest American statesmen were based upon the dictum of Vattel, ${ }^{41}$ to the effect that neutrals are under no obligations to abandon their trade in order that they may avoid furnishing either belligerent with the means of making war. They are undoubtedly a part of the theory and modern practice of International Law in spite of the opposition of a small band

* See Wharton's Digest, III, \& 39I, for these and other expressions of opinion on the part of American statesmen. This doctrine has also repeatedly been laid down by the U. S. Supreme Court. See, e. g., the cases of the Commercen, I Wheaton, 382, and Peterhoff, 5 Wallace, 28, 58; and the Santissima Trinidad, 7 Wheaton, 340. The American view was upheld by Lord Westbury in ex parte Chavasse (1865), 34 L. J. N. S. I7. In 1898 the French Government stated in reference to the case of the Fram, that "the neutral state is not required to prevent the sending of arms and ammunitions by its subjects." Cited by Professor Holland in his letter to the London Times for November 29, 1904. In Ruys v. Royal Exchange Assurance Corporation (1897) a contract for insurance on contraband goods was pronounced valid. See London Times for June I, I897. Cited by Smith and Sibley, p. 404.

il Bk. III, Ch. 7, 8 II I. 
of publicists." ${ }^{42}$ As a leading writer says: "No powerful neutral state has ever interfered to stop a trade in arms and ammunition carried on by its subjects with agents of a belligerent government. No belligerent has ever been prevented by moral scruples or legal prohibitions from buying war material in a neutral market." ${ }^{43}$

To place such restraints upon neutral trade would be not only impracticable in the highest degree, but they might, under certain circumstances, make the burdens of neutrality greater than those of warfare, and tempt neutrals to engage in war as a means of preserving or increasing their trade.

"See e. g., Hautefeuille, Droits des Nations Neutres, Tit. VIII, Sect. IIr; Phillimore, III, § ccxxx; Kleen, Lois et Usages de la Neutralité, $\$ 93$, pp. 378-83. Bluntschli $(\$ 766)$ tries to draw a distinction between large (en gross) and small (en detail) exportation of arms and munitions of war, but as Lawrence (Principles, p. 603) observes, "the diffculty of drawing a line between a small trade and a large one is so great as to amount to impossibility."

Lawrence, Principles, p. 602. 


\section{CHAPTER VII}

\section{The Voyage of the Baltic Fleet, and the Rights and Privileges of Belligerent Armed Vessels in Neutral Ports and Waters}

Next to the questions relating to contraband, the most important issues raised during the Russo-Japanese War from the standpoint of International Law were those connected with the rights and privileges of belligerent armed ships in neutral ports and waters.

One of these questions was raised almost at the very beginning of the war when the Russian gunboat Mandjur remained in the neutral harbor of Shanghai (where she was found lying at the outbreak of hostilities) in defiance of the orders issued by the Chinese authorities, who, acting upon the representations of the Japanese consul, demanded that she leave that port within twenty-four hours. ${ }^{1}$

Japan repeated her demands at Peking and is even said to have threatened a resort to force, but the conduct of the Chinese Government seems to have been extremely weak and vacillating. After prolonged negotiations and repeated

\footnotetext{
1 The reluctance of the Mandjur to leave Shanghai appears to have been due to the fact that at the time a large Japanese cruiser was lying outside the harbor. M. De Lessar, the Russian minister at Peking, maintained, however, that the presence of the Mandjur in Shanghai was necessary for the protection of the Russian Consulate there. This question derived additional importance from the fact that the neutrality of China had in a sense been guaranteed by the Powers. The solution of this problem was anxiously awaited by the whole world. See infra, chapter 9.
} 
agreements to disarm on the part of the Russian authorities -agreements which do not appear to have been effectively carried out-the Mandjur was finally disarmed and dismantled, and the important parts of her machinery and armament were placed in the custody of the Chinese Government toward the end of March, I904. ${ }^{2}$

Another case of the abuse of the hospitality of neutral ports on the part of a Russian vessel arose in February, 1904. The Dmitri Donskoi, a cruiser belonging to the Russian Mediterranean fleet, obtained coal at Port Said on the plea that it was needed to enable her to steam to Cadiz on her return voyage to Russia. But the coal thus obtained for an innocent purpose was used in stopping and overhauling several neutral vessels in the vicinity of the Mediterranean entrance to the Suez Canal. "It is quite clear," says Lawrence, "that Admiral Wirenius exceeded his rights and violated the neutrality of Egypt in a gross and open manner. No proximate acts of war must take place in neutral waters, and they must not be used as a base of operations."

An Associated Press dispatch of February 20, I904, stated that friendly communications had been exchanged between France and Japan in respect to the stay of the Russian Mediterrranean squadron under the command of Admiral Wirenius at Jibutil in French Somaliland-a stay which exceeded the twenty-four hours supposed to be prescribed by International Law. But the "Instructions" of the French Minister of Marine expressly stated that "the duration of sojourn in French ports of belligerents unaccompanied by a

${ }^{2}$ On the case of the Mandjur, see the newspapers from February 19 to March 26, 1904. See especially an article in Collier's Weekly for April 9.

${ }^{3}$ War and Neutrality (2nd ed.), p. II6. 
prize has not been limited by any special provision," and the explanation of the French Government was said to have been entirely satisfactory to Japan. It appears that the French authorities at that port also permitted the Russian vessels to take on a full supply of coal. The British Government, on the other hand, not only insisted upon the enforcement of the twenty-four-hour rule, but, in accordance with the terms of its Neutrality Proclamation, refused to supply the Russian warships with more coal than was needed to carry them to the nearest home port or some nearer named neutral destination.

The Japanese also repeatedly complained of the aid and comfort afforded to the Russian Baltic Fleet on its ill-fated voyage to the Far East from October, 1904, to May 1905. They especially complained of the conduct of France in permitting the use of her territorial waters during its prolonged stay at Nossi-Be off the coast of Madgascar in January and February, as also at Kamranh Bay in French Indo-China in April, 1905.

The voyage of the Baltic Fleet is of particular interest and importance to students of International Law from the fact that it again raised the question as to the right and propriety of furnishing coal to belligerent warships in neutral watersa question which had been raised but not solved, during the American Civil War.

After repeated delays, the main portion or first section of this ill-starred fleet finally sailed from Libau on October I6, 1904, under the command of Admiral Rojestvensky. In order to reach Vladivostok-its ultimate destination-the Russian fleet had to traverse a distance of over I7,000 miles by a route on which Russia had no coaling stations of her own. It was well known that if it ever hoped to succeed in 
traversing even a considerable part of this enormous distance, the fleet must depend upon accompanying colliers-a difficult and dangerous expedient-or upon neutral ports for sufficient supplies of coal.

After coaling from colliers at Cherbourg in France, on October 24, the fleet arrived at Vigo in Spain on October 26. Here it was delayed for four or five days until the preliminaries for the reference of the questions growing out of the North Sea Incident to an international tribunal had been arranged. ${ }^{*}$ At Vigo each vessel was permitted by the Spanish Government to take on 400 tons of coal and the fleet was allowed to exceed the twenty-four-hour rule in consequence of the international complications which had arisen, as also to repair several of its vessels. ${ }^{5}$

The Russian Admiral then proceeded to Tangier on October 30 to November I, where he was apparently permitted by the Moorish authorities to take on a full supply of coal and provisions. At Tangier the fleet divided. One portion was sent via the Suez Canal under the command of Rear Admiral Foelkersahm, while Admiral Rojestvensky himself proceeded southward along the west coast of Africa. No secret was made of the fact that the two divisions of the fleet were to reunite at some point on or near the coast of Madagascar.

Rear Admiral Foelkersahm's division, after coaling at Algiers, arrived at Port Said on November 2, and passed through the Suez Canal on November 24. Our information

- See infra, ch. 8.

- The Japanese Minister at Madrid is said to have made representations to the Spanish Government on this subject. See Chicago Tribune for December 3, 1904 . 
is not clear on the point as to whether coal was furnished to the Russian vessels in Egypt, but a dispatch from Port Said to the London Times, dated November 12, states that they would be permitted "to take provisions and coal sufficient to enable them to reach the next port."

It appears that Admiral Rojestvensky coaled at least twice in neutral ports during his voyage around the Cape of Good Hope-at Dakar on the coast of West French Africa in the middle of November, and at Swakopmund in German Southwest Africa early in December, 1904. Both divisions of the Baltic Fleet were reunited in northern Madagascar early in January, 1905.

The entire fleet remained at Nossi-Be, a small island off the northern coast of Madagascar from January 5 to March I6. The time seems to have been spent in drilling and gun practice, and in increasing the efficiency of the ships. The vessels appear to have been anchored outside the threemile limit, but they were in close communication with the shore from whence they obtained abundant supplies. They coaled from colliers which accompanied them or which had been sent thither from European ports.

During the entire period of the voyage there seems to have been a growing indignation in Japan in consequence of the facilities afforded the Russian fleet for coaling in neutral ports and waters, especially in French territory. Complaints and protests, loud and frequent, were heard on all sides, and the prolonged stay of the Russian Admiral at

- This contemplated breach of neutrality (?) was severely condemned by $\mathrm{H}$. W. Wilson in an article entitled "The Voyage of the Baltic Fleet," published in the National Reviezv for December, 1904. Mr. Wilson claims that in 1898 "Egypt declined to allow Admiral Camera's Spanish fleet to ship a single ton of fuel within Egyptian waters." See also his letter to the London Times (weekly) for November 25, 1904. 
Nossi-Be led to the charge that Madagascar was being used as a base of operation against the Japanese. It was even alleged that the relations between France and Japan became considerably strained in consequence of this fact, but there appears to have been no formal protest on the part of the Japanese Government.

The entire Russian fleet sailed from Nossi-Be on March I 6 and is believed to have coaled at the Chagos islands in the Indian Ocean. It was sighted off Singapore on April 8 and arrived at Kamranh Bay in French Indo-China, several hundred miles north of Saigon, on April 12, where it remained for ten days. A considerable number of the vessels were anchored inside the harbor. ${ }^{7}$ During this time the fleet was freely supplied with coal and provisions by German colliers and Russian transports. It appears that at the beginning of the war the Russian Government had purchased a site and established a coal depot near Saigon. It was apparently from this source that the Russian fleet at Kamranh Bay was largely supplied, ${ }^{8}$ although it was claimed by France that the port officials at Saigon had refused to permit the Russian transports in that harbor to take on more coal than was necessary to carry them to Vladivostok.

These repeated violations of neutrality in French waters raised the growing excitement of the Japanese to a fever heat and at last led to representations at Paris on the part

This is according to a statement issued by the Japanese Navy Department. See Chicago Tribune for April 23, 1905.

- See the cable dispatch of April 30, published on May 8, 1905, which the French authorities at Saigon refused to allow to be transmitted to the New York Sun. See also the admissions of the French concessionaire, the Marquis de Barthelemy, in the London Times (weekly) for May 12, 1905. 
of the Japanese Government, on or about April I9. Finally, yielding to the request of the French authorities backed by instructions from Paris and the express orders of the Czar, Admiral Rojestvensky left Kamranh Bay on April 22 or

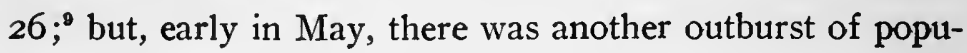
lar anger and excitement in Japan, accompanied by threats of war, in consequence of the continued use of the coast and waters of French Indo-China, more particularly of the Port d'Ayot on the Bay of Van Fong. On May 8 Admiral Rojestvensky's fleet was joined by Nebogatoff's squadron at some point off the Indo-China coast, but the almost total destruction of the entire Russian fleet at the battle of Tsushima in the Korean straits on May 27, 1905, put an end to its erratic career.

Further representations appear to have been made at Paris by the Japanese Government in consequence of the long continued use of the coast and waters of French IndoChina by the Baltic Fleet. Japan cited eight cases of violation of French neutrality, viz., the visits of the Russian fleet to Cherbourg, Dakar, Algiers, Jibutil, Majunga, Nossi-Be, Kamranh Bay, and Port d'Ayot. Japan's statement of her case ended with the following conclusions:

"First-Without impugning the good faith of France, the Japanese Government thinks that the French instructions were inadequately carried out.

"Second-If satisfaction has been given the Japanese observations after the event, it was a pity that more active watch-

- The principal vessels of the fleet left Kamranh Bay on April 22, but they are reported to have returned two days afterwards and to have departed finally with the rest of the squadron on April 26. On April 27 the fleet entered the Bay of Honkoye, where it remained until May 9, 1905. See Nagaoka in Revue Générale de Droit Int. Pub. for 1905, pp. $627-28$. 
fulness was not practiced before, thereby preventing deeds that Japan considers breaches of neutrality.

"Third-Japan does not ignore the complexity of questions of maritime neutrality or France's predilection for her own particular rules; nevertheless, she considers that the aid assured Admiral Rojestvensky, owing to slovenly surveillance, greatly assisted the accomplishment of his mission and his advent into the Chinese seas." 10

In its reply to the Japanese complaints, the French Government entered a general denial on the following points:

r. As regards coal, the Russian fleet never used the privilege of procuring it at French ports, excepting at Algiers, where two torpedo boats took in fifty-seven tons. It was the English and Germans who supplied coal, and Tokio never protested against this action by England or Germany.

2. As regards the strategical use of neutral waters, the French waters never were the scene of the junction of the various Russian squadrons. Coaling at Cherbourg, Dakar, Jibutil, and Nossi-Be took place outside territorial waters. It may have happened close to shore and there may have been intercourse between the fleet and the shore, but not by means of war vessels of any kind.

3. As regards repairs, those made at Cherbourg and Majunga were not in excess of what international practice permits.

As regards the presence of the Russian fleet in IndoChinese waters, the French Government declared Japan's complaints ill founded and laid down the following general propositions :

I. It was impossible to exercise preventive control on account of the extent of the coast line and the absence of tele-

${ }^{10}$ See Chicago Tribune for May 12, 1905. This document was first published in the Paris Temps. It is to be regretted that the Yellow Book on French observance of neutrality during the Russo-Japanese War, announced on May 10, 1905, appears never to have been published. 
graphic stations. The Government did what it could and would do more in this respect.

2. In the matter of coal at Saigon and Kamranh, the quantity bought was not large. Moreover, the coal was bought of private individuals. Japan made no protest when Cardiff sold much larger stocks. The latest instructions sent out provide that no more coal is to be furnished than is necessary to take the fleet to Vladivostok.

3. The shores of Indo-China have not served as a base of operations. According to the best English authorities, a continuous occupation is required to constitute a base of operations.

4. The case of the Diana is proof of the perfectly correct conduct of the French Government. The essential pieces of the guns and machinery were taken out. When it was decided to change its dock, the pieces were put in place again, but immediately afterward they were taken out once more.

The French Government declared the Japanese point of view and Japan's remonstrances unjustifiable for the following reasons :

I. France's impartiality and the circumstances of Admiral Togo's choice of a field in which to give battle brought it about that the Russians were able to stay in Indo-Chinese waters and that the Japanese were unable to obtain the same advantage, but the French Government declines to accept any responsibility for such a situation. If Admiral Togo had gone to meet the Russians at the entrance of the Red Sea, the situation would have been reversed and the Japanese would have profited by the same advantages which the Russians have enjoyed.

2. The Japanese did in the Philippines and the Dutch Indies what they accuse the Russians of doing. That the Japanese squadron cruised for two months in the waters of Singapore, Borneo, and Manila is beyond a doubt. This stay involved frequent relations with the land and unavoidable stays in taking on provisions. 
3. The protest addressed to France alone should have been addressed to the other Powers as well. Before reaching the waters of Indo-China, the Russians coasted along the peninsula of Malacca, where they were joined by their colliers and provisioned with coal, yet no protest was addressed to London.

4. The French reasons, after examination, have been approved by the British Government. Premier Balfour, Lord Lansdowne and Parliament have found the measures taken by France to be satisfactory.

Finally, the five following conclusions were drawn by the French Government :

I. That in law it has completely been cleared by the general and notorious character of its rules of neutrality.

2. That in equity, in spite of the letter of its rules, it had taken certain measures calculated to secure the preservation of absolute impartiality.

3. That as a matter of fact there never were any direct purchases at French ports except at Algiers, and that purchases through the commercial vessels escorting the fleet were insignificant; that, on the contrary, the whole stock of coal for those vessels was bought in England and Germany; that the watchfulness of the French authorities in Indo-China was as keen as the distance and the character of the country permitted.

4. That, at the worst, all the advantages which the Russians may have derived from their use of French ports and waters that would have been assured equally to the Japanese.

5. That, in short, the French Government fulfilled its duty as a neutral Power so far as its means allowed, not only according to the letter, but according to the spirit of the law. ${ }^{11}$

Even admitting that the above documents are not suffi-

${ }^{11}$ From the summary of this document as given by a cable dispatch to the Chicago Tribune for May I2, 1905. 
ciently well-authenticated and that that portion of the law of neutrality which must be applied to them is somewhat vague and uncertain, it is difficult to avoid the conclusion, made on the basis of its own admissions, that the French Government, in permitting the free use of its territorial waters at Nossi-Be and still more at Kamranh Bay and Saigon, violated the spirit, if not the letter of International Law. ${ }^{12}$

The history of the voyage of the Baltic Fleet to the Far East furnishes a good illustration of the existing defects in the present law of neutrality, and especially of the divergence of international practice in the matter of furnishing coal to belligerent warships in neutral ports and waters. It is generally said that, according to International Law, a belligerent armed vessel in a neutral port should not be supplied with coal oftener than once in three months, and then only with a quantity sufficient to take her to the nearest port of her own country or to some nearer named neutral destination.

It is true that this limitation as to coal, first imposed by Great Britain during the Civil War, ${ }^{13}$ now regularly appears in the neutrality proclamations of Great Britain, the United States, and a certain number of other countries. ${ }^{14}$ But the

${ }^{12}$ The failure to prevent the establishment of a coal depot at Saigon by Russia was a most flagrant violation of the letter of the law as well as of its spirit. "It is a breach of neutrality for a neutral to permit a permanent depot or magazine to be opened on its shores, on which a belligerent may depend for constant supplies." Wharton, Commentaries, p. 360 .

${ }^{13}$ On January 3I, I862. These regulations were, however, frequently violated in British ports, at least in behalf of vessels belonging to the Southern Confederacy. The Geneva Board of Arbitration of 1872 refused to consider the mere supplying of coal to warships as constituting a base of naval operations. See De Lapradelle in Revue Générale de Droit Int. Pub., XI (I904), pp. 534 ff.

${ }^{14}$ E. g., in those of Holland, China, Japan, and the Scandinavian coun- 
French "Instructions" of February, 1904, expressly declare that although "a belligerent may in no case make use of a French port for a military purpose," a belligerent vessel may be supplied with "food, commodities, supplies and the means of making repairs (vivres, denrées, approvisionements, et moyens de réparations) which are necessary to the sustenance of the crew and the safety of the voyage."15

The advanced ground taken by England prior to the departure of the Baltic Fleet in this matter of coal supply to belligerent warships in British ports is of great interest and importance. At the beginning of the war the British Government contented itself with the customary prohibitions or limitations noted above, but the Egyptian Government went a step further in the "Notes"16 issued by its Minister of Foreign Affairs on February Io and 12, 1904. These instructions provided that in Egypt "no warship belonging to either of the belligerent Powers shall be furnished with coal without a written authorization obtained from the proper port authorities, specifying the quantity of coal which may be furnished. Such authorization shall be granted by the port authorities only after a written statement from the ship's commander shall have been obtained, stating the des-

tries. See Neutrality Proclamations and Regulations in the House Documents (Foreign Relations volumes) for 1898 and 1904 and in Documents published by the Revue Générale de Droit Int. Pub. for 1904. The Scandinavian States even went so far in April, 1904, as to close absolutely (except in cases of distress) certain of their ports and waters to belligerent warships.

${ }^{25}$ The Neutrality Proclamations of many countries (e. g., those of Germany, Austro-Hungary, Spain, Mexico, etc.) merely enjoin the observance of neutrality without further specification.

${ }^{16}$ For the French text of these "Notes," see the Revue Générale de Droit Int. P., Vol. XI (1904), pp. IO-II and I7-18, under the head of Documents. 
tination of his vessel and the quantity of coal already on board." 17

On August 12, 1904, the Governor of Malta, acting, presumably, in accordance with instructions from the British Government, took a step far in advance of any hitherto taken. He issued a proclamation, ${ }^{18}$ which declared: (I) that a "belligerent fleet proceeding either to the seat of war or to any position or positions on the line of route with the object of intercepting neutral ships on suspicion of carrying contraband of war shall not be permitted to make use in any way of any port, roadstead, or waters subject to the jurisdiction of His Majesty for the purpose of coaling either directly from the shore or from colliers accompanying such fleet, whether vessels of such fleet present themselves to any such port or roadstead or within the said waters at the same time or successively;" and (2) that, except in case of distress at sea, "the same practice shall be pursued with reference to single belligerent ships of war proceeding for purpose of belligerent operations as above defined."

Attention has often been called to the ever-increasing importance of coal to a belligerent warship in modern warfare. As Mr. Lawrence well says in his excellent book entitled "War and Neutrality in the Far East,"-a work which seems to have influenced public opinion in Great Britain and America in no slight degree and whose argument may have greatly influenced the action of the British Government:-

${ }^{17}$ Cf. Lawrence, War and Neutrality, pp. 134-35. These rules were evaded by the Dmitri Donskoi, see supra, p. 189 .

${ }^{18}$ For the full text of this interesting and important proclamation, see the London Times (weekly)-for August 26, 1904, p. 555. The Times adds: "Instructions similar to those embodied in the above proclamation have, we understand, been sent to the Governors of other British colonies and dependencies." 
"Coal has become much more important for warlike purposes than it was in $\mathbf{8 6 2}$. Without it a ship-of-war is a useless log. It is as essential for fighting as ammunition, and much more essential for chasing or escaping. Moreover, the great increase in size or speed, or both, of modern vessels causes them to consume it in much greater quantities than before. A belligerent which can obtain full supplies of it in neutral harbors gains thereby an enormous advantage. The neutral may be perfectly willing to grant similar supplies to the other side, but its wants may be never so great, and consequently, the assistance given to it may never be so effective. Besides, it is of the essence of neutrality that no aid should be given to the belligerents, and this is by no means the same thing as giving aid to both equally." 19

But the objection may be urged that even England regards coal as an article ancipitis usus, and not per se contraband of war. How can the British Government consistently permit its subjects to furnish coal to the enemy in the ordinary way of trade and at the same time forbid its supply to belligerent vessels in neutral ports and waters? Here again Lawrence supplies us with what seems to be a conclusive argument. He calls attention to the fact that if "coal is an article of the first necessity in warfare," it is "equally necessary for peaceful purposes." "An article of commerce may be so essential for hostile purposes that no warship

${ }^{10}$ Lawrence, op. cit., p. 126. See De Lapradelle in Revue Générale de Droit Int. Pub. for 1904 (t. XI), pp. 55I ff, for plausible but unconvincing arguments against Lawrence's view. The main source of the Continental opposition to the limitation or prohibition of the supply of coal to belligerent warships in neutral ports and waters lies, of course, in the fact that most of these states are poorly supplied with coaling-stations of their own as compared with Great Britain. This is also the case with the United States, but arguments based on considerations of national self-interest have no legal value or validity. 
ought to be supplied with it in neutral waters, and yet so essential for the ordinary purposes of civil life that it ought not to be prevented from reaching the peaceful inhabitants of belligerent countries. The two propositions are not inconsistent."20

These arguments derive additional weight and value from a study of the voyage of the Baltic Fleet as outlined above. Without the facilities for coal afforded it in neutral ports and waters (mainly French), it could not possibly have succeeded in circumnavigating the greater part of Europe, Asia, and Africa, with the avowed purpose of attacking the Japanese fleet. Not only have the French "Instructions" proven lamentably insufficient for the purpose of maintaining a real neutrality, but even a strict observance of the British and American rules would not have prevented that fleet from advancing from one neutral port to another by means of coal obtained at a previous port, or from using neutral coasts and waters as bases of supply, or as channels of transportation, even though the fleet itself had remained outside the three-mile limit. Nothing short of the total prohibitions contained in the proclamation of the Governor of Malta would seem to be sufficient for the maintenance of a strict or real neutrality.

For, as pointed out by $\mathrm{Hall}^{21}$ over twenty years ago in a remarkable passage which has proven prophetic: "If a belligerent vessel, belonging to a nation having no colonies, carries on hostilities in the Pacific by provisioning in a neutral port, and by returning again and again to it, or to other similar ports, without ever revisiting her own, the neutral country practically becomes the seat of magazines of stores

${ }^{20}$ Lawrence, op. cit., pp. 162 and 161 .

${ }^{21}$ Treatise (3d ed.), \$ 221, p. 607. 
which, though not warlike, are necessary to the prolongation of the hostilities waged by the vessel. She obtains as solid an advantage as Russia in a war with France would derive from being allowed to march her troops across Germany. She is enabled to reach her enemy at a spot which would otherwise be unattainable."

The present vagueness of the law or principle governing this matter of coal supply to belligerent armed vessels in neutral ports is perhaps best expressed by Professor T. E. Holland in a letter to the London Times:.22 "It is admitted on all hands that a neutral Power is bound not to permit the 'asylum' which she may grant to ships of war to be so abused as to render her waters a 'base of operations' for the belligerent to which these ships belong. Beyond this, International Law speaks at present with an uncertain voice, leaving to each Power to resort to such measures in detail as may be necessary to ensure the due performance of a duty which, as expressed in general terms, is universally recognized." It is sincerely to be hoped that this is one of the subjects to which the coming Hague Peace Conference will give its closest attention.

Much severe criticism was also lavished, especially upon the conduct of the British and German Governments, in permitting vessels carrying the British and German flags to supply the Baltic Fleet with coal. The conduct of Germany in permitting the use of its auxiliary cruisers for such a purpose may be open to criticism; but such trade has always been regarded and treated as contraband of war, although, as Lord Lansdowne observed in a letter to the London Chambers of Shipping and Commerce, British owners char-

2z See London Times (weekly) for April 29, 1904, p. 260. 
tering their vessels for such purposes might render themselves liable to proceedings under the Foreign Enlistment Act of Great Britain. ${ }^{23}$

The question of the rights and privileges of belligerent armed ships in neutral ports came up in a very acute form in the month of August, 1904, when a number of vessels belonging to the Russian fleet at Port Arthur succeeded in escaping to various ports on the Chinese coast after their defeat at the hands of the Japanese on August IO, I904.

Several of the escaped vessels of the Russian fleet sought refuge at the German harbor of Tsing-tau near the entrance of Kiao-chau Bay (the German concession on the Shan-tung peninsula) on the night of August I I, viz., the battleship Czarevitch, the protected cruiser Novik and several torpedo-boat destroyers. The Novik, which was not seriously injured, was ordered to leave within twenty-four hours, in accordance with the instructions of the German Government; and the Czarevitch and several of the torpedoboat destroyers, being in an unseaworthy condition, were not permitted to make repairs. They were, however, permitted to remain to the end of the war on condition that the vessels be disarmed and their crews kept in the custody of the German authorities until the end of the war. ${ }^{24}$ The cruiser Diana sought refuge in the French harbor of Saigon,

${ }^{23}$ See N. Y. Times for November 28, 1904. Lord Lansdowne called attention to the fact that a similar question arose during the FrancoGerman war, when Mr. Gladstone laid down the principle that such colliers would to all intents and purposes become storeships for the fleet.

${ }^{24}$ See the London Times (weekly ed.) for August 19, 1904. The German Government is said to have taken the position that belligerent warships may repair damages for purposes of navigation in any neutral port, but that their armament must not be repaired or augmented. See New York Times for August 14, 1904. 
but was requested to leave within twenty-four hours or dismantle. She was finally dismantled on September ro and her crew interned until the end of the war.

On August I 3 the Russian cruiser Askold and the destroyer Grosovoi arrived at Shanghai-the former vessel being badly damaged, but the latter apparently in fairly good condition. The Russian Consul was at once requested by the Chinese authorities at Shanghai to arrange for their departure from that port within twenty-four hours. He replied that, inasmuch as the ships needed repairs, the Chinese demand was not in accordance with the laws of neutrality, and that reasonable time must be allowed for the necessary repairs. Upon demand of the Japanese Consul that the Russian warships leave Shanghai forthwith or disarm, the Chinese local authorities requested the Commissioner of Customs to report upon their condition and ascertain the period required for repairs. That official having inspected the Grosovoi on August 16, reported that the destroyer's boilers and machinery needed repairs. On the other hand, it was admitted that she had come to Shanghai without reducing her speed.

In the meantime, the situation was changed by the receipt of telegraphic instructions from the Wai-wu-pu and the Nanking Viceroy directing that both vessels forthwith disarm or leave port, and an intimation on the part of Japan that unless this were done, she (Japan) would send a portion of her fleet into the port and capture these vessels, as in the case of the Ryeshitelni. In no case, it was announced, would the Japanese Government tolerate a state of affairs which permits Russian vessels to find asylum in Chinese harbors and make repairs that would enable them to resume belligerent operations. Upon the downright refusal of the 
Russian Consul General to agree even to discuss this proposition, the Chinese authorities again changed front and ordered that a reasonable time be allowed for necessary repairs. But on August 19, after another threat on the part of Japan, the Chinese authorities at Shanghai demanded that the destroyer Grosovoi leave that port within twenty-four hours, and that the cruiser Askold complete her repairs within forty-eight hours and afterward depart within twentyfour hours, or that both vessels disarm. Upon the second refusal of the Russian Consul General to discuss such a proposition, the question was referred to the Consular Body as a whole. This body met on August 22, but failed to accomplish anything, owing to the inflexible opposition of the Japanese Consul to any action affecting the rights of belligerents. On August 23, apparently after the Czar had ordered the disarmament of the vessels, the Chinese executed another volte face, and extended the time for the departure of the warships. On August 25 the Japanese Government addressed a note to the Powers informing them that, unless Russia forthwith disarm her warships at Shanghai, Japan would be forced to take whatever steps she deemed necessary to protect her interests in that quarter. ${ }^{25}$ This veiled threat seems to have had the desired effect, for the Askold and Grosovoi were finally dismantled and disarmed during the first week of September, although not until after further delays, and a long controversy between the Japanese, Russian and Chinese authorities with respect to the disposal of the crews of these vessels. It was at last agreed that the crews be interned in such Chinese treatyports as contained Russian consulates. ${ }^{26}$

${ }^{25}$ See New York Times for August 28, 1904.

${ }^{28}$ The Russians proposed that the precedent set in the case of the 
Another case to be considered in this connection is that of the armed transport Lena, a converted cruiser of the Russian Volunteer Navy, which arrived at the port of San Francisco on September II, I904. Her captain stated that the ship's engines and boilers needed repairs. It was believed at the time that the vessel was on a cruising expedition with the object of preying upon neutral commerce or of capturing Japanese vessels in the Pacific. The Japanese Consul at San Francisco promptly demanded that the vessel be required to leave within twenty-four hours. Mr. Stratton, the Collector of the Port, refused to permit an inspection of the ship by the Japanese Consul, rightly insisting that "the neutrality of the United States will be maintained without regard to any request or act of the Japanese Consul," and that "this matter is between the United States and the Russian Government."27 An inspection of the vessel by the American naval authorities showed that the boilers were in such a bad condition that, although the ship could make ten knots an hour with them, it would not be sea-

Mandjur be followed, and that the crews be sent home at the first opportunity which presented itself. The Japanese insisted, however, that the same procedure be followed as in the cases of the Russian vessels at the German port Tsing-tau, viz., that the crews be retained on Chinese territory. It was claimed by the Japanese that the Russians violated their parole in the case of the paroled crews of the Variag and Korietz, who were drafted later into the service of the Baltic Fleet. See Shanghai dispatch to the Chicago Tribune for August 29, 1904. See New York Times for October 27, 1904, for confirmation of this report.

For the facts bearing on the whole controversy, see especially London Times (weekly ed.) for August 19 and 26 and September 2 and 9, 1904. For some interesting correspondence bearing on this case, see House Doc., 58th Congress, 3d session (Foreign Rel. for 1904), pp. $140 \mathrm{ff}$ and $426-27$.

${ }^{27}$ See the New York Times and Chicago Tribune for September I3, I904. 
worthy in a storm. It was estimated that she would need six weeks for temporary repairs. In the meantime, all necessary precautions were taken to prevent interference or the sending in to the vessel of unauthorized supplies.

Acting upon the written request of the commander of the Lena addressed to Rear-Admiral Goodrich, President Roosevelt issued an order on September I5 that the Russian cruiser be disarmed and taken in custody by the United States naval authorities until the close of the war between Russia and Japan. ${ }^{28}$ The officers and crew of the vessel were detained on parole at San Francisco until the end of the war. $^{29}$

${ }^{28}$ The conditions of disarmament prescribed by the President were: that the Lena be taken to the Mare Island Navy Yard and there "disarmed by the removal of small guns, breech blocks of large guns, small arms, ammunition and ordnance stores and such other dismantlement as may be prescribed by the commandant of the navy yard; that the captain give a written guaranty that the Lena shall not leave San Francisco until peace shall have been concluded; that the officers and crew shall be paroled not to leave San Francisco until some other understanding as to their disposal may be reached between the United States Government and both the belligerents; that after disarmament the vessel may be removed to a private dock for such reasonable repairs as will make her seaworthy and preserve her in good condition during her detention, or may be so repaired at the navy yard if the Russian commander should so elect; that while at a private dock the commandant of the navy yard at Mare Island shall have custody of the ship and the repairs shall be overseen by an engineer officer to be detailed by the commandant and that, when so repaired, if peace shall not then have been concluded, the vessel shall be taken back to Mare Island Navy Yard and be there held in custody until the end of the war." See Mr. Adee to Mr. Takahira in House Doc. of 58th Congress, $3 \mathrm{~d}$ session (For. Rel. for 1904), p. 429. For the correspondence with Russia, see Ibid, pp. $785 \mathrm{ff}$.

${ }^{20}$ It appears that three of the Russian officers of the Lena afterwards broke their parole and went to St. Petersburg. Yielding to the demand of the United States, Russia not only ordered them to return to San Francisco, but reduced them one grade as a punishment. N. Y. Times for February 28, 1905. 
The last set of cases to be considered in this connection is that of the three interned Russian cruisers-the Aurora, Oleg and Jemtchug-which sought refuge in the harbor of Manila on June 3, after the defeat and almost total destruction of the Baltic Fleet in the Korean Strait on May 27, 1905. All of the vessels were more or less seriously damaged, and there were many wounded men on board. The Russian Rear Admiral Enquist asked permission to make repairs and to take on coal and provisions, alleging that he could not sail except in a smooth sea. The naval board appointed by Admiral Train to examine the condition of the Russian cruisers at Manila reported that the Oleg would require sixty days, the Aurora, thirty days, and the Jemtchug, seven days, to effect repairs. Governor Wright is said to have given the Russian Admiral permission to remain long enough to make necessary repairs; but he was overruled by President Roosevelt who, acting, it is said, upon the advice of Secretary Taft, decided on June 5 that the Russian vessels must either dismantle and be interned or leave Manila within twenty-four hours, on the ground that "time can not be given for the repair of injuries received in battle." ${ }^{30}$

This decision is reported to have been criticised in Russia, where it was thought that Admiral Enquist should have been allowed to make such repairs as were necessary to render his ships seaworthy; but no representations on this head

* A distinction is said to have been drawn by Secretary Taft "between the disablement of a vessel caused by a storm or by an explosion or other accident on board, on the one hand, and the damage suffered in battle, on the other." See editorial in N. Y. Sun for June 7, 1905. As the Sun remarks: "The distinction is a just one. It is obvious that a neutral Power which should open its ports to vessels that had been crippled by the enemy for the purpose of enabling them to again take to the sea for an aggressive purpose, would not be exercising impartiality, but really acting as the ally of a belligerent." 
appear to have been made at Washington by the Russian Government, which soon decided in favor of internment. ${ }^{31}$ In the United States the President's decision, which was characterized as a "new principle of International Law," was greeted with a chorus of approval. ${ }^{32}$

In stating the law or custom which has hitherto generally been supposed to govern such cases, it should be observed, in the first place, that the so-called Right of Asylum of belligerent armed ships in neutral ports only exists, if at all, in cases where the vessels are driven into port by stress of weather or when they have otherwise been reduced to an unseaworthy condition; but permission to enter a port and enjoy its hospitality, at least for a short time, is assumed in the absence of any express notice to the contrary. ${ }^{33}$ "Nevertheless it is a privilege based upon the consent of the neutral, and therefore capable of being accompanied by any conditions he chooses to impose." ${ }^{34}$ As stated by Hall, it has

${ }^{11}$ This decision can not have been really unpalatable to the Russians, for the Russian cruisers, once outside of Manila, would soon have fallen victims to the victorious Japanese fleet.

${ }^{32}$ In the case of the Terek, the Government of the Netherlands appears to have assumed a still more extreme attitude than that taken by President Roosevelt in the case of the Russian cruisers interned at Manila. The Russian cruiser Terek arrived at Batavia in Java on June 28, I905, without enough coal on board to enable her to proceed on her voyage. Being unable to take on a sufficient supply within the time fixed for the stay of belligerent warships in that port (twenty-four hours), the port authorities, after consulting with the Home Government, ordered the vessel to disarm and remain until the end of hostilities between Russia and Japan. See N. Y. Sun for August 23, 1905, and London Times (weekly ed.) for July 7, 1905.

${ }^{33}$ See Exchange v. McFaddon, 7 Cranch, i 16.

${ }^{34}$ Lawrence, Principles, p. 509. Such conditions must, however, be impartially applied to both belligerents. Thus Austria prohibited all belligerent men-of-war from entering the port of Cattara during the Crimean War, and Great Britain forbade the access of all belligerent warships to the ports of the Bahama Islands during the American Civil 
hitherto generally been held that "a vessel of war may enter and stay in a neutral harbor without any special reasons; she is not disarmed on taking refuge after defeat; she may obtain such repair as will enable her to continue her voyage in safety; she may take in such provisions as she needs, and if a steamer she may fill up with coal; nor is there anything to prevent her from enjoying the security of neutral waters for so long as may seem good to her.", 35

War. As noted above (see note on p. 199), the Scandinavian countries wholly prohibited the entry into certain of their ports of Russian and Japanese warships soon after the outbreak of the Russo-Japanese War.

${ }^{35}$ Hall (3d ed.), \& 23I, p. 630. But Hall (p. 63I) admits that "in the treatment of ships, as in all other matters in which the neutral holds his delicate scale between two belligerents, a tendency toward the enforcement of a harsher rule becomes more defined with each successive war." As every one knows, the rule is entirely different with respect to belligerent troops which have been driven into neutral territory or which have sought refuge on neutral soil. Such troops are interned and kept there until paroled or until the close of the war. See Arts. 57 and 58 of the Regulations Respecting the Law's and Customs of War on Land adopted by the Hague Conference, Holls, p. I60.

Dana (note 208 to Wheaton, p. 524) thus defines the obligations of neutrals in respect to the use of its ports by belligerent cruisers: "It may be considered the settled practice of nations, intending to be neutral, to prohibit belligerent cruisers from entering their ports, except from stress of weather or other necessity, or for the purpose of obtaining provisions and making repairs requisite for seaworthiness. They must not increase their armament or crew, or add to their belligerent efficiency. It is now the custom to fix a short time for the stay of such vessels, after they have done what is permitted them, or the marine exigency has passed,-usually twenty-four hours. These rules are, however, at the option of the neutral."

Taylor (p. 690) lays down the following rules: "In addition to the observance of all quarantine rules, local revenue and harbor regulations, the belligerent ship must respect all prohibitions designed to prevent the use of the neutral port for the purposes other than those of immediate necessity. While the fighting force of such a ship may not be reinforced or recruited in such a port, nor supplies of arms and war-like stores or other equipments of direct use for war obtained, such supplies and equipments may be purchased as are necessary to sustain life or carry 
It is generally assumed in current discussions (and Japan appears to have acted on this assumption) that it would be a breach of International Law for a neutral state to permit belligerent warships to remain in a neutral port longer than twenty-four hours, except in case of necessity, or to allow such vessels to take in supplies of coal oftener than once in three months, and then only in quantity sufficient to take them to the nearest home port or to some nearer neutral destination. It is true that neutral states are under an international obligation to prevent their ports and waters from being used as a base of military operations or as a constant and regular base of supplies (whether of arms, coal or provisions), or for the purpose of augmenting the force of an armed vessel in the service of a belligerent or of increasing

on navigation. If she is in need of repairs she may procure whatever is needful to put her in a seaworthy condition, including masts, spars and cordage. But she can not make such structural changes as will increase her efficiency as a fighting machine, either of offense or defense. She may take in such provisions as she needs; and, if a steamer, she may purchase enough coal to enable her to reach the nearest port of her own country."

Oppenheim, the most recent authority on International Law (II, $\$ 332$, pp. 354-55), formulates six rules which a neutral is bound to observe in order to prevent "the neutral maritime belt and neutral ports" from being made the base of naval operations. Among these the following are especially noteworthy as bearing upon questions arising during the Russo-Japanese War: (I) "A neutral must, as far as is in his power, prevent belligerent men-of-war from cruising within his portion of the maritime belt for the purpose of capturing enemy vessels as soon as they leave the belt." (4) "A neutral must prevent belligerent menof-war admitted to his ports or maritime belt from taking more provisions and coal than are necessary to bring them safely to the nearest port of their home state." (6) "A neutral must prevent belligerent men-of-war admitted into his ports from remaining there longer than is necessary for ordinary and legitimate purposes." He remarks that "a neutral would certainly violate his duty of impartiality if he were to allow belligerent men-of-war to winter in his ports or to stay there for the purpose of waiting for other vessels of the fleet or transports." 
its military efficiency. It is also true that a considerable practice has grown up in recent times in favor of the twentyfour-hour rule and in favor of strictly limiting the supply of coal permitted to belligerent armed vessels in neutral ports; but the details and specific content of such means or measures for carrying out their international obligations have been left by International Law to neutral governments. ${ }^{36}$

As has been said, neutral governments may impose such conditions upon belligerent armed vessels in their ports or waters as they deem necessary or advisable for the purpose of enforcing their neutral obligations, provided such rules

${ }^{33}$ The rule limiting the stay of belligerent armed vessels in a neutral port to twenty-four hours, "except in the case of stress of weather, injuries or exhaustion of provisions necessary for the safety of the voyage, save that an interval of twenty-four hours must elapse between the sailing of vessels of opponents," was first introduced into international practice by Great Britain during the American Civil War. On January 3I, I862, the British Government published a series of neutrality regulations more stringent than any theretofore issued. They provided that "war vessels of either belligerent should be required to depart within twenty-four hours of their entry, unless they needed more time for taking in innocent supplies or effecting lawful repairs, in which case they were to obtain special permission to remain for a longer period, and were to put to sea within twenty-four hours after the reason for their remaining ceased. They might freely purchase provisions and other things necessary for the subsistence of their crews; but the amount of coal they were allowed to receive was limited to as much as was necessary to take them to the nearest port of their own country. Moreover, no two supplies of coals were to be obtained in British waters within three months of each other." Lawrence, Principles, pp. 310-II.

These restrictions upon the liberty of belligerent warships in neutral ports were adopted by the United States in 1870 , and they have been imposed by Great Britain and the United States in successive wars. They have also been copied, either in whole or in part by other states, $e$. g., by the Netherlands, Brazil, China, the Scandinavian countries, Russia, Japan, etc. It is well known that the twenty-four-hour rule was enforced by Great Britain and Portugal during the Spanish-American War in 1898 . The rule was also enforced by Germany during the Russo-Japanese War. 
or regulations as they choose to make are impartially enforced against both belligerents. But they are bound by the law of nations to make such rules and provide such means for their enforcement as may be necessary to insure a strict and impartial neutrality-a neutrality which consists in absolute abstention from any acts or services which would directly tend to strengthen the fighting forces of either belligerent or which would amount to an actual or potential participation in the war. For this reason a belligerent armed vessel should not be allowed to remain in a neutral port for a longer period of time than is absolutely necessary in order to procure innocent supplies or to effect repairs requisite for seaworthiness; and steamships should not be allowed to coal except in case of necessity, and then only to take on a quantity sufficient to take them to the nearest home port or (better still) to the nearest available neutral destination. ${ }^{37}$

In the light of the lesson read to the world during the Russo-Japanese war by the Baltic Fleet, may we not add that a belligerent armed vessel or fleet proceeding to the seat of war should not be permitted to make use of neutral ports or waters for the purpose of coaling or of making repairs? As Premier Balfour, speaking on the question of the use of neutral ports by belligerents, said in the House of Commons in August, 1904: "The essence of the matter is that neutral ports ought not to be used as bases for hostile operations, and neutrals ought not to allow their coal or

${ }^{37}$ It has also been customary, for a century or more, to interpose a time limit of twenty-four hours between the sailings of two or more hostile ships in neutral waters. The object of this rule is to prevent fighting in the neighborhood of these waters. It dates from the middle of the eighteenth century. This is the custom which is generally referred to in older treatises as the twenty-four-hour rule. See, e. g., Hall, Treatise, $3 \mathrm{~d}$ ed., note on p. 631. 
anything else to be used for the purpose of facilitating such operations." 38

The measure or amount of repairs permitted or supplies allowed to belligerent armed vessels in neutral ports should be determined by what is absolutely needed to render them navigable or seaworthy ${ }^{39}$ as distinct from rendering them more efficient as fighting machines or increasing their warlike capacity." "Speaking generally, we may say that a belligerent ship must not leave a neutral port a more efficient fighting machine than she entered it, except in so far as increased efficiency may come from increased seaworthiness or a better supply of provisions. On the other hand, neutrals may permit the supply of things necessary for subsistence, and they may repair in these ports and waters damage due to the action of the sea. A distinction is drawn between what is necessary for life and what is necessary for war." 41

It appears from the foregoing account that a series of new precedents has been created in this war in favor of the view that belligerent armed vessels seeking refuge in neutral ports ought to be dismantled and disarmed, and their crews pa-

See London Times (weekly) for August 19, 1904, p. 535.

* If the precedent set by President Roosevelt in the case of the Russian cruisers interned at Manila be followed in future wars (and it is to be hoped that this will be done) we shall have to add "unless for injuries received in battle."

* Under this rule the engines and boilers of such a vessel might be repaired, but not so her guns or armament.

"Lawrence, War and Neutrality (2nd ed.), p. 121. Lawrence adds: "It is not very logical, because a man must live before he can fight, and those things which keep him in health fit him to perform his duties as a combatant. But, such as it is, it has to be observed." The rule seems to be a sort of compromise between the obligations of humanity and comity on the one hand and of neutrality on the other. Cf. Taylor, p. 690 , and Oppenheim, II, $\$ 346$. Oppenheim permits slight or small repairs of the vessel herself, but not of the armaments. 
roled or detained until the end of the war, as in the analogous case of defeated or fugitive troops seeking refuge from defeat or pursuit on neutral territory in warfare on land. But the force of these precedents is perhaps somewhat weakened by the fact that some of the Russian vessels cited sought refuge in Chinese territory under the shadow of a Government which was incapable of guaranteeing a perfect neutrality or of perfectly fulfilling its neutral obligations. It may also be suspected that the Russian Government, under the circumstances, was not wholly averse to disarmament under proper guarantees of protection from attack, such as could be furnished by the Governments of Germany and the United States. ${ }^{42}$

In any case the force and validity of the twenty-four-hour rule was greatly strengthened during this war, and the conduct of the Powers in refusing or strictly limiting supplies of coal to Russian warships of the Baltic Fleet shows that modern governments are becoming more fully alive to their neutral duties in this respect also. It looks as though a new chapter in the history of International Law has been written, and it would seem that governments now take a very different view of their neutral obligations than they did in the days when Confederate cruisers, built or purchased in foreign ports, were able to begin and complete their errands of destruction without ever having as much as touched at a Confederate port.

\footnotetext{
"In the case of the Lena, at any rate, this action was taken at the express request of the Russian commander.
} 


\section{The North Sea Incident}

The most sensational incident of the Russo-Japanese War was the so-called North Sea outrage. On the evening of October 23, 1904, several British steam trawlers arrived at Hull, in England, and reported that early on the morning of October 22 (toward I A. M.) nearly fifty small vessels, belonging mainly to the Hull "Gamecock" steam fishing fleet, had been suddenly attacked and fired upon on the high seas by warships belonging to the Russian Baltic squadron then on its ill-fated voyage to the Far East. It appears that on the night in question, which was rather dark and somewhat foggy, these fishing vessels were quietly engaged, under the direction of their admiral, in trawling for cod off the Dogger Bank in the North Sea. All the boats carried their proper lights, and they were employing the conventional rockets in signalling to each other, when they observed that the searchlights of several steamers belonging to the first division of the Baltic Fleet were being turned upon them. This group of steamers passed on, but a second group approached, and presently a third, using searchlights and making signals. One of the vessels belonging to the third group suddenly opened fire, which soon became more or less general. After ten or twelve minutes the firing ceased as suddenly as it had begun, and the Russian vessels continued their voyage without making the slightest attempt to save 
life or to ascertain the amount of damage they had done. ${ }^{1}$ It was soon learned that one trawler had been sunk and five others more or less damaged. ${ }^{2}$

This apparently wanton and deliberate attack upon innocent fishermen was regarded by the English as merely the culminative event in a long series of "outrages" of which Russia had been guilty during the war, and it naturally stirred up British public feeling and opinion to the highest pitch of excitement and expression. The London newspapers were unanimous in their demand for apology and reparation, and even men like Sir Frederick Pollock denounced it as "an act of war."

On October 24 Lord Lansdowne instructed Sir Charles

${ }^{1}$ Lord Lansdowne to Sir Charles Hardinge in Correspondence Relating to the North Sea Incident, Parliamentary Blue Book on Russia, No. 2 (1905), No. 2. The fishermen claimed that a Russian ship was detached to watch them. This vessel was said to have remained on or near the scene of action for about six hours, without offering aid. Admiral Rojestvensky denied that any Russian vessel had remained behind, and argued that it must have been a Japanese torpedo boat which the fishermen saw. The British "Observations" (see Archives Diplomatiques, t. 94, pp. 475 ff.) suggest that it was the Russian transport Kamchatka, which had remained in the rear of the fleet in consequence of an accident to her machinery, and which, believing herself to be attacked by torpedo boats, fired upon the Swedish vessel, Aldebaren, and other unknown vessels on the evening of October 21. See paragraphs 5 and 6 of the Report of the Commissioners.

${ }^{2}$ See Art. 13 of the Report of the Commissioners, published as a Parliamentary Blue Book on Russia, No. 3 (1905), and the Coroner's Verdict in London Times (weekly) for November 4, 1904.

${ }^{3}$ Lord Roseberry referred to it as "an unspeakable outrage," and Sir H. C. Campbell-Bannerman called it "an atrocious act" and "an unparalleled and cruel outrage." The King of England contented himself with a milder characterization. He simply called it "an unwarranted action." Perhaps the Hon. A. Lyttleton, Secretary of State for the Colonies, best expressed the general opinion in England when he declared that the tragedy was "either the result of a murderous intention or of wicked negligence." 
Hardinge, the British ambassador at St. Petersburg, to inform Count Lamsdorff of what had occurred, and to say that "the indignation provoked by the incident can not possibly be exaggerated." In this communication the British Secretary of State for Foreign Affairs did not hesitate to declare that "the whole action would seem to have been of the most deliberate character," and that it "can only have been due to the most culpable negligence." He concluded as follows:- "The matter is one which admits of no delay. His Majesty's Government prefer not to formulate their demands until the explanations, which no doubt the Russian Government will hasten to lay before them, have been received, but it will be their duty to require ample apology and complete and prompt reparation, as well as security against the recurrence of such intolerable incidents." 4

On October 25 the following message from the Czar was brought to the British Embassy in St. Petersburg by Count Lamsdorff :

"No report has reached His Majesty from Admiral Rojestvensky, and he can therefore only consider that the unfortunate accident which has taken place off Dogger Bank must be attributed to an unfortunate misunderstanding. The Emperor is, however, anxious, in view of the sad loss of life which has taken place, to convey to His Majesty, the King, and to His Majesty's Government his sincere regrets at the occurrence;

'Blue Book on Russia, No. 2 (1905), No. 2. In his verbal reply (No. 3) to the representations of the British ambassador, Count Lamsdorff urged that "he had no information beyond that given by the panicstricken fishermen," the correctness of whose deposition he was unable to admit. But he assured Sir Charles Hardinge that "thorough inquiries would be made, and, if any persons were found guilty of such action, adequate punishment would be inflicted on them, and full reparation be made to the sufferers." He felt sure that some "terrible misunderstanding" had arisen, the solution of which, without inquiry, was impossible. 
His Majesty will take the necessary measures of reparation to the sufferers as soon as a clear account is given of the circumstances in which the incident occurred."s

These assurances were deemed wholly inadequate by the British Government as well as by the public and the newspapers, a considerable section of the London Press even going to the extent of demanding that the Baltic Fleet be stopped and forcibly detained, and that the Russian Admiral, together with those of his officers responsible for the outrage, be peremptorily cashiered and disgraced without further investigation.

In the meantime English feeling against Russia ran higher and higher. Preliminary orders for the mobilization of the British fleets were issued by the British Admiralty. The Channel, Mediterranean, and Home squadrons were ordered to meet at Gibraltar with a view of intercepting the Russian fleet on its way southward in case such action were necessary, and instructions for the mobilization of 25,000 naval reserves were said to have been issued. ${ }^{\boldsymbol{B}}$

In an interview with Count Benckendorff, the Russian ambassador at London, on the morning of October 25, Lord Lansdowne, while not undertaking finally to formulate the demands of the British Government, intimated that they must include: (I) an ample apology and disclaimer from the Russian Government; (2) the fullest reparation to the sufferers; (3) a searching inquiry with a view to finding out who were to blame for what must in any case be regarded as "a culpable blunder," and "adequate punishment of

${ }^{B} O p$ cit., No. 8. Count Lamsdorff added that the incident appeared to him "incomprehensible."

- See Associated Press dispatches for October 26, I904. The last statement lacks official confirmation by the British Government. 
the persons, whoever they might be, who proved to be responsible;" (4) security against a repetition of such incidents. ${ }^{?}$

In reply to a communication sent by Count Benckendorff, who had again expressed the deepest regret of the Russian Government at the "unfortunate incident," and who repeated the Czar's promise of ample reparation to the sufferers, Lord Lansdowne assured the Russian ambassador that this was "not enough." In a personal conference with Count Benckendorff on the same day (October 26) the British Minister used very plain language indeed. Commenting upon the evident fact that, although the Russian Admiral had failed to make a report, no effective steps had apparently been taken to intercept the fleet at Vigo, he called the at . tention of the Russian ambassador to the concentration of the British fleet at Gibraltar and remarked that if the Russian fleet "were allowed to continue its journey without calling at Vigo, we might find ourselves at war before the week was over." This language appears to have had the desired effect, for the Russian Government contrived to let Admiral Rojestvensky know that he must stop at Vigo in Spain.

In an interview which a representative of the Associated Press secured from Admiral Rojestvensky soon after the latter's arrival at Vigo on October 26, the Russian Admiral expressed great regret at the incident, and explained that the "unfortunate occurrence was purely accidental." He stated that, on the night in question, two torpedo-boats. which seemed to be discharging torpedoes, ${ }^{\ominus}$ had suddenly

'Blue Book, op. cit., No. 10.

- Ibid., No. 12.

- One Russian officer, Prince Keretelli, thought he saw eight torpedo 
appeared between the two divisions of his squadron, and that the Russians, supposing them to be Japanese craft, immediately opened fire. He denied having seen either lights or fishermen, and was not aware that any damage had been done. On the following day (October 27) Count Lamsdorff read to Sir Charles Hardinge two telegrams which had been received at St. Petersburg from Admiral Rojestvensky. The second of these telegrams stated that "the incident in the North Sea was provoked by two torpedo-boats which, without lights and protected by the obscurity, prepared to attack the leading vessel of the squadron. When the squadron began to show war signals and then to fire, several other small steamers resembling fishing vessels were discovered. The squadron tried to spare these vessels, and stopped firing as soon as the torpedo-boats disappeared. . . . The squadron could not render assistance to the small steamers, who might be suspected of complicity in view of their obstinate attempts to break the line of our ships. There were some boats which had not lit any lights at all, others very late." "I0 "In the above-mentioned circumstances," claimed

boats. The N. Y. Times for October 27, 1904. In a subsequent interview published in the London Daily Chronicle for October 29, Admiral Rojestvensky is quoted as having said that two men were wounded on his flagship during the firing, and that one of his vessels-the Aurora-was so badly damaged as to need repairs. As the Report of the Commissioners (Art. 14) observes, "the fact that the Aurora was hit . . would lead to the supposition that this cruiser, and perhaps even some other Russian vessels, . . . might have provoked and been the object of the first few shots."

${ }^{10}$ Blue Book, cited above, No. 15. The first suggestion to the effect that the firing upon the trawlers was due to the actual or suspected presence among them of Japanese torpedo-boats was made by M. Sazonow, the Russian charge d'affaires at London, to Lord Lansdowne on October 24. See op. cit., No. 6. On October 27, ig04, Count Lamsdorff assured Sir Charles Hardinge that he had received positive proof that 
Admiral Rojestvensky, "no warships could have acted otherwise, even in time of profound peace."

The publication of these statements by the Russian Admiral served rather to inflame than to soften the anger and exasperation of the British public. They were regarded as insolent and flippant in tone, and as insulting as well as injurious to the honor and majesty of the British nation in substance. The London Times described them as a "tissue of palpable untruths," and urged that since "Admiral Rojestvensky claims the privilege of piracy on the high seas," it is "unsafe to suffer him to be at large in command of warships." 11

The English were united in demanding the punishment of the "guilty officers" responsible for this outrageous attack upon innocent fishermen. Nevertheless the publication of

twenty Japanese officers had arrived at Hull a few days before the incident, and that attacks of such a nature were being planned. Not a particle of evidence tending to prove this assertion was ever produced. Op. cit., Nos 14 and 15 .

There is plenty of evidence which goes to show that Admiral Rojestvensky and other officers of the Baltic fleet suffered from extreme nervousness, and that they were in great fear of mines or of attacks by Japanese torpedo-boats. A dispatch to the Berlin Lokal Anzeiger, dated October 27, stated that the German fishing vessel Sonntag had been fired upon off Dogger Bank on October 21. The master of the Norwegian steamship Staatol reported from London on the 27 th that he was fired on by a Russian ship on October 23 in the English channel. The skipper of the Swedish steamer Aldebaran stated that his vessel was chased in the Skagerack on October 21 by a foreign cruiser, apparently Russian. See Chicago Tribune for October 28, 1904. It was also reported that a Danish torpedo-boat had been fired upon. The Russian transport Kamchatka, which fired upon the Aldebaran and other unknown vessels on the evening of October $2 \mathbf{1}$, imagined that she was being attacked on all sides by torpedo-boats. See Arts. 2-7 of the Report of the Commissioners; the Russian recital of the facts in Archives Diplomatiques for 1905, No. I, pp. 97-99; and the Russian "Observations and Conclusions" in the Archives for 1905, No. 4, pp. 482 ff.

${ }^{11}$ See London Times, editorial, for October 28, 1904. 
these very statements of Admiral Rojestvensky's, which so greatly increased the indignation of the British public, and which seemed only to add fuel to the fire, paved the way for the peaceful settlement of the affair; for the British Government could not fairly ask the Russian Government to summarily reject the official report of its Admiral as false or incredible, and accept the statements of "panic-stricken fishermen" without further inquiry.

Immediately upon the receipt of the Russian Admiral's explanation of the affair, Lord Lansdowne formulated the following demands and presented them to the Russian ambassador at London: (I) Before the Russian fleet leaves Vigo, an inquiry shall be made by Russian authorities as to those persons responsible for the attack on the fishing fleet. All those whose testimony is essential to the elucidation of the facts are to be left behind. (2) A full inquiry shall be held at once as to the facts by an independent court of an international character. It was suggested that this commission might be formed of naval officers of high rank representing the two Powers concerned and several others, and that it might be governed by the procedure laid down in Articles IX to XIV of the Hague Convention for International Commissions of Inquiry. (3) The Russian Government shall agree to undertake to punish adequately any person found guilty by this Commission. Lord Lansdowne ${ }^{12}$ assured the Russian ambassador that, "if these demands were conceded, the acute character of the crisis would disappear, as the Russian Government had already expressed their deep regret, promised liberal compensation, and undertaken to prevent the recurrence of similar incidents."

${ }^{12}$ Lord Lansdowne to Sir Charles Hardinge, Blue Book on Russia, op. cit., Nos. 17 and 19. 
In response to these demands the Russian Government promptly ordered Admiral Rojestvensky to remain at Vigo with those ships and officers by whom the North Sea incident was witnessed, ${ }^{13}$ and on the following day (October 28) the principle of an International Commission of Inquiry, "as contemplated by the Hague Convention," was accepted by the Czar in the form of a counter-proposal. 14 "As for the question of punishment, Count Lamsdorff stated that he could not admit the guilt of any Russian officer until the results of the inquiry were known; it would then be time to apportion responsibilities and their consequences on whomsoever they might be found to fall. He therefore declined to discuss this now." 15

As a result, however, of further negotiations, on the same day (October 28), between Lord Lansdowne and Count Benckendorff, it was finally agreed that any persons found guilty by the International Commission of Inquiry would be tried by the Russian Government and punished adequately. ${ }^{10}$ It was also agreed that the Russian Government would is-

${ }^{13}$ Ibid., Nos. 2I, 23, 28 and 45.

16 Ibid., No. 22. It has been claimed that the Czar's counter-proposal was made without knowledge of the previous proposition by Lord Lansdowne; but it is difficult to see how this is possible, inasmuch as Count Lamsdorff's proposal was made before noon of the 27th and the Czar's counter-proposal is dated St. Petersburg, October 28. The difference in time between London and St. Petersburg is not sufficiently great to account for such a delay. Besides, it appears that Count Lamsdorff, at least, had knowledge of Lord Lansdowne's proposal before his audience with the Czar on October 28. See Ibid., No. 45.

${ }^{13}$ Sir Charles Hardinge to Lord Lansdowne, op. cit., Nos. 23 and 45.

${ }^{16}$ Ibid., Nos. 27 and 28 . "There never was any question in regard to apology and compensation," Count Benckendorff was quoted as saying. "These were freely conceded. The only approach to a hitch occurred in connection with the question of guarantee of punishment." See N. Y. Times for October 29, 1904. 
sue instruction ${ }^{17}$ to the whole Russian fleet, so as to secure neutral commerce from risk of interference and prevent a repetition of such incidents.

Accordingly, as a result of these negotiations, Premier Balfour was able to announce these terms of agreement to the world, in a speech at Southampton, on the evening of October 28.

Mr. Balfour's statement, which had been authorized by Count Benckendorff, the Russian ambassador, and which presents in concise form the results of the negotiations up to this point, was as follows : ${ }^{18}$

"The Russian Government, on hearing of the North Sea incident, at once expressed their profound regrets, and the Russian Emperor telegraphed to the King in the same sense. The Russian Government also promised the most liberal compensation. They have now ordered the detention at Vigo of that part of the fleet ${ }^{19}$ which was concerned in the incident, in order that the naval authorities may ascertain what officers were responsible for that incident. These officers and any material witnesses will not proceed with the fleet on its voyage to the Far East. An inquiry will be instituted into the facts. The Russian Government consider that for this purpose it would be useful to intrust this inquiry to an International Commission of the kind provided for by the Hague Convention. Any persons found guilty by this tribunal will be tried by the Russian Government and punished adequately. The Russian Government undertakes that precautions will be taken

${ }^{17}$ Such instructions were given to Admiral Rojestvensky before he left Vigo. See Blue Book, cited above, No. 54.

${ }^{13}$ See Nos. 27 and 28 of the Blue Book, cited above.

${ }^{19}$ This statement was interpreted by a large section of the British public and newspapers to mean that these vessels would be detained at Vigo. As a result of this misunderstanding, there was renewed excitement when the entire Russian fleet sailed away from Vigo on November I, 1904. Only four Russian officers were left behind as witnesses. 
to guard against the recurrence of such incidents, and with this object special instructions will be issued to the whole Russian fleet, so as to secure neutral commerce from all risk."

In his speech upon this occasion, the British Prime Minister severely criticised and ridiculed Admiral Rojestvensky's assertion that he had been attacked by Japanese torpedo-boats. He expressed his disbelief in the "phantom Japanese ships" in substantially these terms: "In the story of our fishermen there was much tragedy, but no romance; in the story of the Russian Admiral there is no tragedy, but I am driven to the belief that there is much romance. It is impossible to doubt which story is substantially correct. The Admiral's story is really an attack upon our national honor, and implies that we are not doing our duty as neutrals. . . . In an island kingdom like Great Britain the nationality of every craft is known. It is inconceivable that we should be harboring Japanese sailors and warships without Russia and, indeed, the whole civilized world knowing it. I enter a most emphatic protest against such an allegation."

Referring to the doctrine, which Admiral Rojestvensky was said to have held, to the effect that his officers were justified in firing on any boat that came too near his ships, $\mathrm{Mr}$. Balfour said: "One difficulty was that the fleet which committed the outrage was on its way to the illimitable East. That difficulty has been gotten over, but there is another difficulty-namely, that the Russian Admiral appears to have a theory of the rights and duties of belligerent fleets as against neutrals that would really make the high seas a place of public danger. ${ }^{20}$

\footnotetext{
${ }^{20}$ The correspondent of the London Daily Telegraph at St. Petersburg
} 
"Suppose some dark night a liner or transport fell in with the Baltic Fleet at Gibraltar, where they intended to divide, and approached within the magic distance, according to the Admiral's theory he would be justified in sinking it. The position is one impossible for neutrals to tolerate. A fleet animated by that policy would be a fleet which would have to be eliminated out of existence if civilized commerce is to pursue its way unimpeded."21

In the negotiations which followed, regarding the organization and scope of the Commission of Inquiry thus agreed upon, there was only one question which presented any serious difficulty. Lord Lansdowne insisted from the first that the Commission should consider and pass upon the "degree of blame" as well as the "responsibility" attached to those involved in the attack upon the fishing fleet. ${ }^{22}$ Article II of the British draft of the proposed agreement, submitted on October 3I, provided that the Commission "shall inquire into and report upon all the circumstances attending the disaster in the North Sea, and particularly as to where the re-

made the following statement to his journal in a dispatch, dated October 28, 1904: "I am enabled to state categorically that Admiral Rojestvensky received from the Russian Admiralty a code of secret instructions, not only authorizing but obliging him to fire upon all ships approaching too close, or otherwise arousing suspicion."

${ }^{21}$ Telegraphic summary of Mr. Balfour's speech in the New York Times for October 29, 1904. For a complete report of this remarkable speech, see London Times (weekly ed.) for November 4, 1904 Mr. Balfour attributed this wise provisional solution of the affair to the wisdom of the Russian Government, which "had shown an enlightened desire that truth and justice should prevail," and to the Czar, who "had shown himself an enlightened judge of what was right in the matter as between nation and nation;" but it was generally believed at the time that this happy outcome was largely due to the unceasing activity and good offices of M. Delcassé, the French Minister of Foreign Affairs, and of M. Cambon, the ambassador for France at the court of St. James.

${ }^{22}$ See especially Nos. 41 and 43 of the Blue Book, cited above. 
sponsibility for the disaster lies, and the degree of blame which attaches to those upon whom the responsibility is found to rest." 28 Count Lamsdorff objected to the wording of this article on the ground that "it assumed the culpability of Russian officers." ${ }^{24} \mathrm{He}$ said: "It is the work of the Commission of Inquiry alone to determine the responsibility for the incident, and he could not admit the responsibility or guilt of the officers detached until proved by that body." ${ }^{25}$

In spite of this apparent difference of opinion, Count Lamsdorff announced, on November 4, that the Russian Government had accepted the six articles of the British draft proposals "integrally.",26

The negotiations leading up to the establishment of the

${ }^{23}$ See inclosure in No. 43, p. 27.

${ }^{24}$ Ibid., No. 56.

${ }^{25}$ No. 57. This difference of opinion appears, as Lord Lansdowne pointed out in No. 58 , to have been a mere "verbal misunderstanding." One would think it might easily have been removed by adding to Art. II, cited above, the phrase "if blame there be." As Lord Lansdowne said: "The International Tribunal (!) alone can determine whether responsibility is equivalent to guilt or is in itself deserving of punishment." $\mathrm{He}$ added: "We do not regard this as necessarily the case, but in our view the persons who are responsible are those on whom blame would fall, if blame there was."

The Russian view appears to have been that the officers detached at Vigo were to be regarded as mere witnesses, and there was to be no presumption of blame or responsibility; the English view was that those implicated in or responsible for the incident were to be detached as well as those who might be regarded as mere witnesses. Lord Lansdowne admitted, however, that "since those officers who were actually implicated would be in the best position to give evidence, the selection of certain individuals as witnesses did not exclude the possibility of their having been responsible in the matter." See No. 57 .

${ }^{26}$ Nos. 59, 60, and 65. Three additional articles, proposed by Count Lamsdorff on November 5, were accepted by the Russian Government on November 8. See Nos. 62,67 and 68 . They dealt with the appointment of Legal Assessors and Agents to assist the Commission in their deliberations. 
Commission of Inquiry seemed thus happily ended when Sir Charles Hardinge received, on November I2, from Count Lamsdorff the French translation of a Russian draft of the proposed agreement, drawn up (so Count Lamsdorff assured the British ambassador) in accordance with the nine articles of the English text. He explained, however, that, "besides corrections of an editorial character," Article II of the agreement had been "worded in somewhat altered form as compared with the English text." 27 But it was found that besides certain changes in the preamble, ${ }^{28}$ the phrase "degree of blame" had been omitted in the new Russian draft.

The British ambassador at once protested, reminding Count Lamsdorff of the integral acceptance by the Russian Government of the English $\mathrm{draft}^{29}$ on November 4, and awaited instructions from London. On November I4 he was informed by Count Lansdowne that the British Government could not now "consent to a controversy as to the form of the Agreement," and that it desired to adhere to the original text as proposed by Great Britain and agreed to by Russia. $^{30}$

The reason given by Count Lamsdorff for the proposed change was that, "after consultation with the best Russian jurists, M. de Martens at their head, he had come to the conclusion that the original text of Article II was contrary to

${ }^{27}$ No. 72.

${ }^{23}$ So, e. g., the English draft of the preamble spoke of referring the question in dispute to an International Commission of Inquiry analogous to that provided for by the Hague Convention. The Russian draft substituted the word conformably for analogous. For the text of the Russian draft, see inclosure 2 of No. 79 .

${ }^{20}$ Nos. 73 and 79 .

${ }^{30}$ No. 75 . 
the sense of the stipulation of the Hague Convention relating to the appointment of a Commission of Inquiry ;" ${ }^{11}$ but, as Lord Lansdowne pointed out, the Commission contemplated by the British Government was not identical with, but "analogous" to those recommended by the Hague Conference. ${ }^{32}$ Count Lamsdorff then explained that the hitch in the negotiations had been due to a misunderstanding,, ${ }^{33}$ and he placed no further impediments in the way of a final agreement. The Declaration of St. Petersburg (as the agreement providing for the organization and scope of the International Commission of Inquiry to investigate the North Sea Incident was called) was signed by Sir Charles Hardinge and Count Lamsdorff on November 25, $1904 .^{.34}$

As eventually adopted, the troublesome Article II provided that "the Commission shall inquire into and report on all the circumstances relative to the North Sea incident, and particularly on the question as to where the responsibility lies, and the degree of blame attaching to the subjects of the two High Contracting Parties or to the subjects of other countries in the event of their responsibility being estab-

${ }^{81}$ No. 76.

${ }^{32}$ No. 77.

${ }^{3}$ Nos. 82 and 88 . This misunderstanding consisted in the fact that the Russian Government had supposed that the stipulation of the Hague Convention was to constitute the sole basis of the agreement, whereas the British Government desired to give the Commission of Inquiry more extended powers than those recommended by the Hague Conference.

In accepting the final draft proposed by Russia, Great Britain stipulated that "should the Instrument about to be signed prove to be in any way inconsistent with the provisions of the Hague Convention (Articles IX to XIV), the Articles of the Instrument shall be held to override those of the Hague Convention." No. 84 and inclosure in No. 90.

"For the French and English texts of this Declaration, see Blue Book, cited above, inclosure I in No. 96. For the English text, see appendix to the Blue Book. 
lished by the inquiry." Article IX of the Hague Convention for the Peaceful Adjustment of International Differences provides that "in differences of international nature involving neither honor nor vital interests, and arising from a difference of opinion on matters of fact, the Signatory Powers recommend that parties who have not been able to come to an agreement by diplomatic methods should, as far as circumstances allow, institute an International Commission of Inquiry to facilitate a solution of the differences by elucidating the facts, by means of an impartial and conscientious investigation." ${ }^{35}$ Article XIV of the Convention provides that "the report of the International Commission of Inquiry shall be limited to a statement of the facts, and shall in no way have the character of an arbitral award."36

A comparison of these texts, reinforced by a study of the negotiations, make it clear that the powers granted to the International Commission of Inquiry for the investigation of the North Sea Incident were much broader than those contemplated by the Hague Conference. The Declaration of St. Petersburg imposed upon the Commissioners the duty of determining the question of responsibility and apportioning the degree of blame attached to those responsible for the attack on the Hull fishing fleet as well as "the task of elucidating by means of an impartial and conscientious investigation the questions of fact connected with the incident," ${ }^{37}$

${ }^{35}$ See Holls, Peace Conference, pp. 203 and 387.

${ }^{\text {se Ibid., pp. } 219 \text { and } 389 .}$

${ }^{37}$ From the preamble to the St. Petersburg Declaration. See Appendix of Blue Book. Lord Lansdowne (No. 78) claimed that the "question of responsibility and question of blame are both questions of fact." Count Lamsdorff (No. 77) appears to have held that the "question of responsibility is a question of fact, but that the question of blame is not." 
and the report of the Commission certainly had more or less of the character of "an arbitral award." 38

Prior to the meeting of the Commission of Inquiry in Paris in January, 1905, separate inquests or investigations were made by Russian and British authorities. There appears to have been an inquiry by the Russian officials at Vigo in the latter part of October, 1904, and, in addition to the Coroner's inquest at Hull, early in November, the Board of Trade conducted an inquiry at $\mathrm{Hull}^{39}$ on November I5-I9, I904. ${ }^{40}$ The findings of these various inquests or inquiries supplied the Russian and British Governments with the material for their respective "Recitals of Facts,"41 submitted to the International Commission of Inquiry.

The International Commission of Inquiry for the investi-

${ }^{38}$ M. Mandelstam (see Revue Générale de Droit International Public for Mars-Juin and Juillet-Août, 1905 , pp. 178 ff. and pp. $413 \mathrm{ff}$.) is of the opinion that the Declaration of St. Petersburg, in combining the functions of a court of arbitration with those of a court of inquiry, created a "hybrid" which should not serve as a model in future conventions of this sort.

In his Southampton speech Mr. Balfour had asserted that the International Commission of Inquiry about to be established by Great Britain and Russia "had nothing to do with arbitration." It was, said he, instituted merely "to find out the facts." Such may have been the intention of the British Government at that time, as it certainly was of the Russian Government; but the Commission of Inquiry as instituted by the Declaration of St. Petersburg was given the functions of a court of arbitration as well as those of a commission of inquiry.

${ }^{30}$ For the proceedings and findings of the Board of Trade inquiry, see London Times (weekly) for November 18 and 25, 1904, pp. 742 and p. $76 .^{1}$ The Commissioners appointed to conduct the inquiry were Sir Admiral Cyprian Bridge and Mr. Butler Aspinall. They were instructed to report upon: (I) the facts; (2) upon the quantum of the damage of whatever kind, and as to compensation.

${ }^{40}$ A later session for the consideration of claims for compensation was held on December 19.

${ }^{41}$ For the Russian and British "Recitals of Facts," see Archives Diplomatiques for 1905, No. I, pp. 97-102. 
gation of the North Sea Incident met in Paris on January 9, $1905 .{ }^{42}$ It was composed of five naval officers representing the Governments of Great Britain, Russia, the United States, France, and Austria. ${ }^{43}$ The sessions from January 9 to January 20 were occupied in the elaboration and adoption of rules of procedure. ${ }^{44}$ Thirteen public ${ }^{45}$ sessions from January 25 to February 2 (inclusive) were occupied in the examination of witnesses, and on February 13 certain

${ }^{42}$ It had met and held its first session on December 22, I904, but this was merely for the verification of powers and the selection of the fifth member of the Commission in accordance with Art. I of the Declaration of St. Petersburg.

${ }^{4}$ These were Vice-Admiral Doubassoff for Russia, Vice-Admiral Beaumont for Great Britain, Rear Admiral Davis for the United States, Vice-Admiral von Spaun for Austro-Hungary, and Admiral Fournier of the French navy who presided. Each of the two High Contracting Parties was represented by a legal Assessor "to advise the Commissioners," and by an Agent "officially empowered to take part in the labors of the Commission." See Art. I of the Declaration. It appears from the Correspondence (No. 68) that the "Agents" were intended "merely to act as intermediaries between the Commission and the Governments concerned." In reality they acted as prosecuting-attorneys for their respective governments and interpellated the witnesses. They were assisted by counsel and advocates, and seem to have played a much more important rôle than the "Assessors." See Mandelstam in article cited above, pp. 362-372.

"For the Reglement or rules of procedure governing the work of the Commission, see the Archives Diplomatiques (t. 93) for 1905, pp. 102107, and the article by Mandelstam, cited above, in the Revue Générale $D$. I. $P$. for 1905, pp. $357-360$. For the minutes or reports of the official proceedings of the sessions, see Archives Diplomatiques (t. 94) for 1905, pp. $450-496$.

${ }^{45}$ With reference to the degree of publicity, the sessions of the Commission were of three kinds: (I) public, $i$. $e$, open to a certain number of outsiders, e. g., newspaper correspondents (such were all sessions devoted to the reading of the exposition of facts, of conclusions, and the report, as also the interpellation of witnesses); (2) not public, $i$. e., open only to persons in any way connected with the Commission (such were all sessions held for purposes of deliberation); (3) sessions in the Council Hall, in which, in principle, only the Commissioners and Assessors participated. See Mandelstam in article cited above, p. 374. 
"Observations and Conclusions" were presented to the Commission by the Agents of the British and Russian Governments.

The Agent of the British Government contended that the evidence of the witnesses and documents presented to the Commission had established the following "Conclusions":

"I. That on the night of October 2I-22, I904, there was in fact no torpedo-boat or torpedo-boat destroyer present among the British trawlers or in the neighborhood of the Russian fleet; and that the Russian officers were mistaken in believing that vessels of this kind were present or close by and that they attacked or intended to attack the Russian fleet.

"2. (a) That there was no sufficient reason to justify the opening of the fire; (b) that, once opened, there was a failure to direct and control the firing so as to avoid damage to the fishing fleet; (c) that the fire upon the fishing fleet was continued for an unreasonable length of time.

" 3 . That those on board the Russian fleet should have gone to the aid of the wounded and the damaged vessels.

"4. That no fault whatever was committed by those on board the trawlers or by those in charge of them."

The "Conclusions" drawn from the evidence by the Agent of the Russian Government were as follows :

"I. That the firing of the Russian squadron on the night of October 2I-22, I904, was ordered and executed in legitimate accomplishment of the military duties of the Commander of the squadron.

"2. That, as a consequence, no responsibility can possibly rest upon Admiral Rojestvensky or any of his subordinates." ${ }^{\prime 6}$

46 For the British and Russian "Observations and Conclusions," see Archives Diplomatiques (t. 94) for 1905, pp. 474-489. For a good English translation of the "Conclusions," see B. H. Conner in the Green Bag for June, 1905, Vol. XVII, pp. 362-63. 
During the inquest Russia endeavored to justify the conduct of her Admiral and officers by trying to show: (I) that the firing was caused by the rapid approach, at a distance dangerous to the squadron, of two actual torpedoboats, which all of the Russian officers present at the inquest claimed to have seen; (2) that the firing was exclusively directed upon these torpedo-boats, and that the British trawlers were merely hit in consequence of a series of inevitable accidents $;^{47}$ (3) that everything possible was done by the squadron to lessen the risks which the trawlers inevitably ran as a result of the firing necessitated by the approach of the said torpedo-boats. The Russians laid great stress upon the excellent quality and "high moral value" of their evidence, which was produced by witnesses who were high naval officials, and who were supposed to speak from direct personal knowelge of all the facts. They pointed to the purely negative character of the British evidence ${ }^{\mathbf{4}}$ as to the absence of the torpedo-boats, as compared with the positive evidence of professional experts who testified, one and all, to the presence of such vessels. The fact that these witnesses were also interested appears to have been overlooked.

The Report of the International Commission of Inquiry was rendered on February 25, I904. The majority of the Commissioners expressed the opinion that "the responsibil-

${ }^{37}$ This claim does not well accord with Admiral Rojestvensky's dispatch, cited above. He had accused the trawlers of "obstinate attempts" to break through his line.

${ }^{48}$ This evidence was of two kinds: that of the fishermen and that of the Governments of France, Germany, Denmark, Holland, Norway and Sweden, and Japan, all of which denied having any knowledge of the acquisition or equipment of any Japanese torpedo-boats in the ports of these countries, or of the existence of such vessels in the vicinity of Dogger Bank on the night in question. See Blue Book on Russia, No. 2 (Ig05) passim. 
ity for the action and the results of the fire to which the fishing fleet was exposed are to be attributed to Admiral Rojestvensky;" ${ }^{40}$ and since it was unanimously agreed that the trawlers had committed no hostile act, and since it was the opinion of the majority that there were no torpedo-boats either among the trawlers or anywhere near," the opening of fire by Admiral Rojestvensky was not justifiable. ${ }^{50}$ But, on the other hand, the majority of the Commissioners considered the precautions taken and the standing orders issued by the Russian Admiral "in no way excessive in time of war, and particularly in the circumstances" $;^{61}$ and they unanimously recognized that he "personally did everything he could, from beginning to end of the incident, to prevent trawlers, recognized as such, from being fired upon by the squadron." ${ }_{52}$ They also unanimously recognized that "after the circumstances which preceded the incident and those which produced it, there was, at the cessation of the fire, sufficient uncertainty with regard to the danger to which the division of vessels was exposed to induce the Admiral to proceed on his way." 53 In conclusion, the Commissioners declared that their findings were "not, in their opinion, of

"See Art. XI, \& 6, of the Report.

"Art. I3, \& 4. The majority also held "the time during which the firing lasted on the starboard side" to have been "longer than was necessary." 8 I, Art. 15.

51 84 of Art. 8. These standing orders of the Admiral "laid down that the officer of the watch was authorized to open fire in case of an evident and imminent attack by torpedo-boats." \$ 2, Art. 8 .

${ }^{82}$ Art. ${ }_{15}, \& 3$.

w 2 of Art. I6. The majority of the Commissioners regretted, however, that "Admiral Rojestvensky, in passing the straits of Dover, did not take care to inform the authorities of the neighboring Maritime Powers that, as he had been led to open fire near a group of trawlers, these boats, of unknown nationality, stood in need of assistance." Ibid., 8 . 
a nature to cast any discredit upon the military qualities or humanity of Admiral Rojestvensky, or of the personnel of his squadron."

The North Sea Incident was finally closed on March 9, 1905, by the payment to Lord Lansdowne by the Russian ambassador of $\mathfrak{f 6 5 , 0 0 0}$ as indemnity or compensation due to the Hull fishermen.

The Report of the North Sea Commission was severely

"Art. 17. The Commissioners found that the firing was due to the "extreme precautions" taken by the Russian vessels "in order that they might be fully prepared to meet a night attack by torpedo-boats, either at sea or at anchor." They declared that "these precautions seemed to be justified by the numerous reports received from the agents of the Imperial (Russian) Government on the subject of hostile attempts to be feared, which in all likelihood would take the form of attacks by torpedoboats." See Report, Art. $2, \$ \S 2$ and 3. They suggested that the firing may have been incidentally caused by the "accidental delay" of the Russian transport Kamchatka, which, having been "obliged to slacken speed in consequence of damage to her engines," was "left behind and isolated about ten miles to the rear of the squadron."

Towards 8 P. M. of October 2I the Kamchatka, "doubtless in consequence of the anxiety inspired in the circumstances of the moment, the damage to her engines, and her small fighting value," opened fire upon the Swedish vessel Aldebaran and other unknown vessels. At 8:45 P. M. the Commander of the Kamchatka sent a message by wireless telegraphy to Admiral Rojestvensky regarding this encounter, stating that he was "attacked on all sides by torpedo-boats." The Russian Admiral, who was at that time about fifty miles ahead of the Kamchatka, was thus led to fear an attack by these alleged torpedo-boats upon his division, and he accordingly signaled his ships at about 10:00 P. M. "to redouble their vigilance and look out for an attack by torpedo-boats." The expected attack occurred towards i:30 A. M. See Report of the Commissioners, Art. 2-9. The majority of the Commissioners observed that "they did not have sufficiently precise details to determine what was the object fired on by the (Russian) vessels." Art. 13, \& 4 . The British Agent (see "Observations" in Archives Diplomatiques (t. 94) for I905, p. 478) presented weighty arguments in favor of the British view that the vessels first seen and fired upon were the Russian cruisers Aurora and Dmitri-Donskoi. The Aurora was hit by several shots. 
criticised in some quarters on the ground that it was a "Scotch verdict." It was said, e. $g$., that the Commission had found that, "though the Russian Admiral was utterly unjustified in turning his guns loose on the helpless fishermen, and that he acted in an extremely reprehensible manner, his conduct was characterized by discretion and valor, and the court is unanimous in holding that he is a fine fellow and a credit to the squadron and the Russian nation." 55 It was intimated that the decision of the Commission was actuated by a desire to conciliate both parties rather than to mete out justice, or that they wished to avoid the imposition of such blame upon the Russian Admiral as would render his trial and punishment by Russia necessary.

Such criticism appears to have been unjust. As our foremost American authority on International Law, ${ }^{56}$ John Bassett Moore, has well said: "It is not improbable that, if the Commissioners had been lawyers instead of admirals, they would have avoided any ground for such a surmise. Had they been lawyers, they probably would have brought out more clearly the distinction, which doubtless was working in their minds, between justification in fact and apparent justification. They found that the attack was not in fact justified, and from this finding there arose an obligation to make compensation. But when we pass from the domain of civil to that of penal law, when we pass from the question of making compensation for a wrongful act to that of undergoing personal punishment for it, the element of intent becomes material, and apparent rather than actual justification

ss See editorial in N. Y. Press for February 26, 1905.

* For the citation which follows, see the report of the eleventh Annual Meeting of the Mohonk Lake Conference on International Arbitration for 1905 , p. 150 . 
or excuse becomes the test. The Commissioners therefore are not chargeable with inconsistency, because, while they found that the firing was not justifiable, they also held that Admiral Rojestvensky had not incurred liability to punishment." It would thus seem that the decision of the Commissioners amounted to a finding that, although the Russian Admiral was responsible for the firing, he was in no wise chargeable with such a kind or degree of blame as would render him liable to trial and punishment at the hands of the Russian Government. ${ }^{57}$

The institution of the North Sea Commission and its successful working under such trying circumstances must be pronounced a great victory for the principle of international arbitration. Although nominally called an International Commission of Inquiry analogous to those provided for by Articles 9-I 4 of the first Hague Convention, it really combined the functions of an International Court or Tribunal of Justice with those of a Commission of Inquiry and, in accordance with the purposes for which it was organized, it passed upon the questions of "responsibility" and "degree of blame" as well as inquired into and reported upon the facts or circumstances of the case. It was in fact an arbitration sui generis, of a kind new and unprecedented in the history of international relations; for it was not only applied, at a time of great excitement, to a question affecting the national honor and vital interests of both parties to the dispute, but it introduced into our administration of international justice a new method of procedure in cases of alleged violations of the law of nations. It has set a precedent for the establishment of tribunals combining the functions of

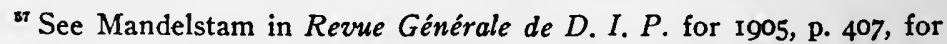
a corroborative view. 
an International Court of Arbitration with those of a Court of Inquiry for the investigation and trial before the bar of the public opinion of the world, of those charged with international crimes and misdemeanors or serious violations of International Law. It is true that the accused in this case, if found guilty, were to have been punished by a national penal sanction; but the power of imposing an international censure was vested in the North Sea Commission by the Declaration of St. Petersburg, and, although the organization and procedure of the Commission may be open to criti$\mathrm{cism}^{58}$ in matters of detail, there is no valid reason why the principles involved in this case should not be given even a more extended application.

For the finding itself there seem to be no precedents ${ }^{59}$

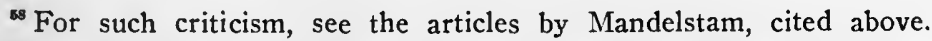
This author recognizes the great service which the Declaration of St. Petersburg has rendered to arbitration by "the extension of its domain to infractions of the law of nations" (see p. $4 \mathrm{I} 5$ of the Revue cited above), but he considers the organization and procedure of the North Sea Commission to have been so defective that he hopes it may "not serve as a model for future Commissions of Inquiry." $\mathrm{He}$ especially objects to combining the functions of a Court or Tribunal of Arbitration with those of a Commission of Inquiry, but on what appear to us to be purely theoretical grounds. The best answer to such an objection is to be found in the successful working of such an institution under such trying circumstances as surrounded the North Sea incident. Not only was a great European war thus narrowly averted, but the questions involved were settled once for all. Had the Russian view for which Mr. Mandelstam contends prevailed and the scope of the Commission been restricted to an inquiry into the facts and to the determination of the question of "responsibility," the question of "degree of blame" or guilt would have remained open as a possible source of future strife and contention between the two countries. It is a point worth considering, however, whether in future disputes of this kind the interests of neutrals would not receive more consideration at the hands of a Commission of international lawyers or jurists rather than at those of admirals or generals.

${ }^{50}$ Among the many supposedly analogous cases, such as the Maine, 
strictly in point. Under the peculiar circumstances of the case and in principle the decision of the Commissioners seems sound, and we have no inclination to find fault with it. It is to be hoped, however, that it will not be distorted into a precedent for the support of a theory of belligerent as against neutral rights on the high seas, which appears to have been entertained in high quarters during the RussoJapanese War.

Count Cassini is reported to have said: "A fleet is like a fortress, and when the sentinel calls out to the stranger to

Virginius, Caroline, etc., cited by Smith and Sibley in their work (see pp. 295-319), there are only two which seem to have any real bearing upon the main points raised by the North Sea Incident. These are the cases of the Marianne Flora (II Wheaton I), decided in 1826 , and the Waima incident of 1893 .

In the former case it was held by the United States Supreme Court that when two armed vessels engage in combat under a mutual misapprehension as to each other's real character, and the vessel attacked captures the attacking vessel under the false impression that she is a pirate, and brings her into port for adjudication, the capture is not unlawful. But it was also held that there was no ground for the confiscation of the captured vessel in such a case, nor for giving costs and damages to its owner. The court formulated the following principles of public maritime law to govern such cases: "Ships of war sailing under the authority of their government in time of peace have a right to approach other vessels at sea for the purpose of ascertaining their real character, so far as the same can be done without the exercise of visitation or search, which does not exist in time of peace. No vessel is bound to await the approach of armed vessels under such circumstances; but such vessels can not lawfully prevent their approach by the use of force, upon the mere suspicion of danger." The Marianne Flora, II Wheaton $\mathrm{I}$.

In the case of the Waima incident in 1893 , which was submitted to arbitration, compensation was awarded by France for an attack by French troops (mostly colored) upon a British camp at Waima in the Conno country. The attack, which was due to a deplorable mistake, resulted in considerable loss on both sides. See Smith and Sibley, pp. 312I4, for an account of this incident. 
halt, and he does not obey the summons, or acts suspiciously, the immediate consequence is a shot." 60

Admiral Rojestvensky was credited with holding that his officers were justified in firing upon any vessels that approached too near his squadron, and the Russian naval officer, Captain Klado, in his testimony before the Commission, cited with evident approval an English Admiral who had once said that "if a torpedo-boat approached his squadron during the night, even in time of peace, he would first sink it and afterward inquire into its nationality." 1

A British naval officer was thought to have expressed the prevalent opinion in naval circles in the following comment :

"The opinion is strongly held by officers of our own and other European navies that a fleet of warships at sea in time of war should not allow any war vessel it can not identify as a neutral to approach it. It is generally held, too, that a merchant vessel should be kept off unless it is known to be well disposed, for otherwise there is nothing to prevent a belligerent from chartering a merchant vessel and doing a lot of damage with her to the enemy's fleet.

"No doubt the Russian Commander thought two of his small cruisers, which suddenly appeared, were Japanese torpedoboats, and if he did, his only proper course was to fire on them. It is really nothing remarkable that cruisers should be taken for torpedo-boats, for there isn't a navy in the world in which the same blunder has not been made. I counted up sixteen authenticated cases the other day, involving the best navies in the world, the British and American not excepted." 62

In reply to Count Cassini's view it may be urged that a

\footnotetext{
${ }^{\infty}$ See interview in the N. Y. Times for October 24, 1904.

"See London Times (weekly) for January 31, 1905.

'See special cable of December 19, 1904, to the N. Y. Times.
} 
fortress is stationary, whereas a fleet or vessel on the high seas is usually in motion, and therefore less liable to sudden and unforeseen attack. Besides, those who approach a fortress, as a rule, do so voluntarily and with full knowledge of its whereabouts, whereas the poor Hull fishermen were wholly innocent even of any knowledge of the proximity of the Russian fleet, which was considerably out of its course. The fishermen were pursuing their ordinary peaceable avocation in a place where they had a perfect right to be, when they were suddenly surrounded and attacked without any warning ${ }^{63}$ whatsoever.

In a letter to the London Times for May 25, 1904, Professor Holland thus states the law regarding belligerent and neutral rights on the high seas :

"It is beyond doubt that the theoretically absolute right of neutral ships, whether public or private, to pursue their ordinary routes over the high seas in time of war is limited by the right of belligerents to fight on those seas a naval battle, the scene of which can be approached by such ships only at their proper risk and peril. In such a case a neutral has ample warning of the danger to which he would be exposed did he not alter his intended course. It would, however, be an entirely different affair if he should find himself implicated in belligerent war risks, of the existence of which it was impossible for him to be informed, while pursuing his lawful business in waters over which no nation pretends to exercise jurisdiction."

This statement of the law, which we believe to be correct, certainly lends no support to the extravagant claims of belligerent rights on the high seas advanced in certain naval

${ }^{63}$ Count Cassini admitted that a stranger approaching a fortress or sentinel is entitled to a warning. Such a warning at sea is given by means of a blank shot. 
circles, or to the apparent assumption in Russia of the right of the Baltic Fleet to traverse the high seas in disregard of the rights of neutral vessels, forbidding them to approach at their peril. If such a view were to prevail every belligerent warship on the high seas might become a source of public danger and a menace to neutral commerce. It is to be hoped that at its next session, the Hague Peace Conference will take into consideration the matter of rights and duties of belligerent warships on the high seas, and frame satisfactory rules and regulations on this important subject. 


\section{CHAPTER IX}

\section{The Hay Note and Chinese Neutrality}

One of the most important and difficult problems which confronted the world during the Russo-Japanese War was that of maintaining the neutrality and integrity of the Chinese Empire. In order to preserve the integrity and neutrality of China proper, as well as to restrict the area of hostilities as much as possible, Secretary Hay, acting, it is said, at the suggestion of Germany, sent the following instructions to our representatives at St. Petersburg, Tokio and Peking on February 10, 1904:

"You will express to the Minister for Foreign Affairs the earnest desire of the Government of the United States that in the course of the military operations which have arisen between Russia and Japan, the neutrality of China and in all practicable ways her administrative entity ${ }^{1}$ shall be respected by both parties and that the area of hostilities shall be localized and limited as much as possible, so that undue excitement and disturbance of the Chinese people may be prevented, and the

${ }^{2}$ The phrase "administrative entity" was thought by some to be ambiguous. It is not really so, for it must mean the administrative integrity of that portion of the Chinese Empire which was actually administered or governed by Chinese officials. It, at least, included China proper, i. e., the eighteen provinces south of the Great Wall and east of Thibet, and probably Mongolia. Manchuria and Korea were, of course, excluded, as also those portions of Chinese territory which had been leased to the Powers. On the phrase "administrative entity," see an article by Professor Moore on "Mr. Hay's Work in Diplomacy" in the American Review of Reviews for August, 1905 (Vol. 32, pp. 174-75), and a letter by the writer to the N. Y. Nation for April 27, rgo5 (Vol. 80, p. 330). 
least possible loss to the commerce and peaceful intercourse of the world may be occasioned."

At the same time all those Powers particularly interested in the fate of China were informed of this action on the part of our Government and invited to take similar action. Favorable replies were received from nearly all the leading European Powers, and the principles embodied in the Hay Note were also accepted by China, Russia and Japan.

The acceptance of Russia was, however, accompanied by certain reservations which threatened future troublesome complications. In its reply of February 19, the Russian Government signified a willingness to respect the neutrality of China on the following conditions: (I) that China herself "strictly observe all the duties of neutrality;" (2) that the Japanese Government "loyally observe" not only the "engagements entered into with the Powers," but, in addition, "the principles generally recognized by the law of nations;" and (3) that "neutralization be in no case extended to Manchuria." Japan, on the other hand, in her reply of February I3, merely stipulated that the "region occupied by Russia" be excluded from the neutral area, and that "Russia, making a similar engagement, fulfill in good faith the conditions and terms of such engagement."2

It will thus be seen that both Russia and Japan made their acceptance of the main principle of the Hay Note, viz.,

2 For the text of the Hay Note and the replies of Japan and Russia, see House Doc. of 58 th Congress, 3d session (Foreign Rel. 1904), p. 2. For the replies of the other Powers, see the same volume, passim. Of the Powers consulted-Austria-Hungary, Belgium, Denmark, France, Germany, Great Britain, Italy, the Netherlands, Portugal and Spainthe last alone made a distinctly unfavorable reply. The replies of several Powers, e. g., Austria-Hungary and Belgium, indicated a somewhat lukewarm or indifferent attitude. 
the maintenance of the neutrality of China proper, conditional upon its observance by the other belligerent. This was entirely reasonable and proper; but Russia, in addition, stipulated for a strict observance of the duties of neutrality on the part of China and of the law of nations on the part of Japan. Several large loop-holes were thus carefully left open by Russia, as means of escape from her obligations in case such an attempt were deemed advisable. Inasmuch as numerous disputes regarding neutral rights and obligations as between neutrals and belligerents, as also charges and countercharges of violations of the law of nations between the belligerents themselves, are bound to arise in every war, and inasmuch as each party is its own judge in these matters, it was not difficult to see that the future contained possibilities of considerable complication and controversy. Pretexts infinite in number and variety would not be wanting to Russia, if she desired to avoid the natural consequences of her engagement.

The term "neutrality," as applied to China by the Hay Note, appears to have had a double meaning. In the first place, it meant that China was to be "neutralized" during the struggle, $i$. e., she was not to be permitted to become a party to the war. This might perhaps be called a temporary as opposed to a permanent neutralization like that of Belgium and Switzerland. It was neutralization under a sort of international guarantee of the Powers, although less formal and perhaps less effective than those of Belgium and Switzerland, which were the results of great international treaties. It might, however, under certain circumstances, prove to be a step in the direction of permanent neutralization. If such guarantees are to prove wholly successful, the guarantors must, of course, be ready and willing to resort 
to other means than those of "moral suasion" or "pressure of public opinion" in case of necessity. Whether the Powers were prepared to resort to the use of force in the case of China was extremely doubtful, to say the least.

In the second place, the maintenance of Chinese neutrality, as implied in the Hay Note, meant that hostilities or hostile preparations must not be carried on within the territorial limits of China proper, i. e., in those parts of China administered by Chinese officials. This was, to a certain extent, merely the guarantee of a right already in existence, viz., of the undoubted right of China to remain neutral, if she so desired, and to have her territorial sovereignty respected during the struggle by both belligerents. The violation of this right by either belligerent would have constituted a gross breach of International Law in itself which it might have been the duty of China to resist by force of arms; and, in case China herself were incapable of such an effort, such an attack might have been resisted by any State which chose to champion her cause, although such knighterrantry is rare among nations except where their national interests are involved. The right of the Powers to take such measures as were deemed necessary in order to prevent or to defeat an attack upon the neutrality of China was clear and unquestionable.

It was clearly understood on all sides that Manchuria, or that portion of the Chinese Empire which was administered, in accordance with treaty stipulations, by Russian officials for certain purposes and was actually occupied by Russian troops, should be exempt from the application of the principles of the Hay Note. The international status of Manchuria during the war appears to have been that of "double 
or ambiguous sovereignty.", In such cases the territories or districts in question owe a nominal allegiance to one sovereign, but are really subject to the commands of another who is in actual possession. It is possible for such a place or region to possess a belligerent and a neutral character at the same time-belligerent in respect to the belligerents and neutrals, and neutral in respect to the nominal sovereign and his relations with other states. "The precise legal position of these territories, is very difficult, and perhaps impossible, to determine." One modern publicist, who carefully examined the question, came to the conclusion that "a juristic examination of these relations can only lead to negative results; it is a political provisional arrangement in which law and fact are in contradiction to each other."'s

The law which should govern in all such anomalous cases is, however, reasonably clear and well-defined. "The belligerency or neutrality of territory subject to a double sovereignity must be determined for external purposes, upon the analogy of territory under military occupation, by the belligerent or neutral character of the state de facto exercising permanent military control within it. . . . When a place is militarily occupied by an enemy, the fact that it is under his control, and that he consequently can use it for the purposes of his war, outweighs all considerations founded on the bare legal ownership of the soil. In like manner, but with stronger reason, where sovereignty is double or ambiguous a belligerent must be permitted to fix his atten-

'Other examples of double or ambiguous sovereignty are Bosnia, Herzogovina, Cyprus, and Egypt. These territories or districts are under the nominal sovereignty of the Sultan of Turkey, but are really administered by Austrian and English officials.

'Hall, Treatise, note on p. 509 of $3 \mathrm{~d}$ ed.

'Holzendorf, Handbuch, II, \$ 5 I, quoted by Hall in note cited above. 
tion upon the crude fact of the exercise of power. He must be allowed to deal his enemy blows whenever he finds him in actual military possession, unless that possession has been given him for a specific purpose, such as that of securing internal tranquillity, which does not carry with it a right to use the territory for his military objects. On the other hand, where a scintilla of sovereignty is possessed by a belligerent state over territory where it has no real control, an enemy of the state, still fixing his attention on facts, must respect the neutrality with which the territory is practically invested."

In view of the anomalous position of China in respect to Manchuria during the war, and also because of the vast interests involved and the great danger to the peace of the world which might have resulted from any serious violation of Chinese neutrality (whether by either or both belligerents or by China herself), it is not surprising that the Press of all countries (and particularly of our own) was very sensitive to any charges of a violation of the neutrality of China (especially by Russia), and that much was said by way of criticism and denunciation which was either unjust or impolitic.

Several weeks after the outbreak of the war Admiral Alexieff issued a somewhat quaint and curious proclamation to the inhabitants of Manchuria, of which there was much unfair criticism. This manifesto, which contained "six regulations which all must tremblingly obey," after charging the Japanese with treachery in covertly attacking the Russian fleet while peaceful negotiations were in progress, laid especial stress upon the indissoluble unity of Russian and

- Hall, op. cit., p. 5 II. 
Chinese interests in Manchuria. He expressed the opinion that since "Russian and Chinese interests are intertwined, like a cart and its prop, mutually dependent," it was the duty of all to join in attacking and resisting the invader. But since the Chinese Government "desires to keep its hands in its sleeves and maintain an attitude of neutrality," he urged all officials (Chinese) of Manchuria to render the Russian army every possible assistance in obtaining supplies, and he directed all the inhabitants of Manchuria to treat the Russian troops with "sincerity and good feeling." He declared that he would hold all law-abiding people, residing in the neighborhood of Manchurian railways or telegraph or telephone wires, responsible for their protection, and that the local officers concerned, together with the gentry and village elders must, with united purpose, devise means to prevent damage. Should attempts at destruction be made, not only would the offenders themselves be severely punished, but the officials and people of the vicinity who "sit by" and witness such attempts would be held responsible. $\mathrm{He}$ also threatened severe punishment against any one privily harboring or concealing the Chunchuses, or red-bearded brigands of Manchuria. He finally declared that should "any of the Chinese officials or people treat the Russian troops with enmity, the Russian Government will assuredly take measures to exterminate such persons, showing no leniency."7

While the language of this proclamation is certainly somewhat harsh and the penalties prescribed rather severe, they do not seem to go beyond the rights of an invader or

${ }^{7}$ For the text of this curious and interesting proclamation, see the London Times (weekly ed.) for February 26, 1904. See also House Doc. of the 58th Congress, 3d session (For. Rel. 1904), pp. $127 \mathrm{ff}$. 
a military occupant, nor do they constitute a violation of Chinese neutrality, as was charged in some quarters. As has been noted above, Manchuria was not included within the sphere of Chinese neutrality as far as the belligerents in their relations with each other and with neutrals were concerned. ${ }^{8}$ The status of Manchuria was one of double or ambiguous sovereignty which is closely analogous to that of a territory or district under military or belligerent occupation. Under such circumstances, pillage or mere plunder is strictly forbidden, and private property on land is not subject to capture and confiscation; but the invader or military occupant has an undoubted right to levy and collect fines, requisitions and contributions for strictly military purposes, and he may, if he chooses, make the war support itself. These should, however, be as orderly and as light as possible, and they should not exceed the needs of the troops or the resources of the district in which they are levied. Above all, it should never be forgotten that the fundamental law of warfare is that of reasonable military necessity, and that only so much violence is permitted in war as is necessary for self-protection and the destruction of the enemy's power of resistance. The fact that Admiral Alexieff insisted that the Chinese in Manchuria treat Russian soldiers in a friendly or non-hostile manner, or even that they were required to furnish the Russian army with supplies and with carts for purposes of transportation was no evidence of an intention or a desire to violate Chinese neutrality, as the American Press seems to have regarded it, nor was it a breach of the laws of civilized warfare. Nor was there any violation of law or custom in the severe pen-

'It was neutral in respect to the relations between China and other states. 
alties prescribed for the destruction of railways or of telegraph and telephone wires, or the harboring of brigands.

Almost from the very beginning of the war the alleged violations of Chinese neutrality by China and Japan were made the subject of frequent protests and complaints on the part of Russia. Japan also at times complained of such violations by China and Russia, but her protests appear to have been less formal and persistent than were those of Russia.

It was said that the Russian minister at Peking made firm representations to the Chinese Government as early as March, 1904, concerning the activity of the Chinese troops along the Manchurian frontier ; ${ }^{3}$ that Russia at the same time served notice on China that the latter must not send troops beyond the Great Wall ; and that China was informed that she must use her influence to restrain the Chinese bandits (who were spoken of as partially under the control of Chinese officials) from interfering with the railway and telegraph lines. It was also stated that Russia notified China that a refusal to heed these warnings would be considered a breach of Chinese neutrality, and that China received a pointed intimation of the defensive measures which Russia might in that case be compelled to take for her own protection.

The dispatch of 18,000 Chinese troops to the Manchurian

'On March 4, I904, Mr. Conger, the American representative at Peking, reported to the State Department at Washington that 18,000 Chinese troops had been sent to the border of Manchuria to preserve order in accordance with the Chinese Neutrality Proclamation. He stated that because of Russia's opposition the troops that were originally intended to be sent into that part of Manchuria which had already been surrendered to China (i.e., the region west of the Liao River) would be kept on the west side of the Manchurian border. See House Doc. of 58 th Congress, 3d session (For. Rel. I904), p. I28. 
frontier was not a menace to Russia, inasmuch as it had for its object the perfectly legitimate one of preserving order and of protecting the neutral rights of China against possible or probable encroachment. It was certainly not a violation of Chinese neutrality. The request that China use her influence to restrain the Chinese bandits in Manchuria as far as possible seems to have been a perfectly proper one to make in itself, although, to be sure, it would have been absurd for Russia to claim that China could be held responsible for any degree or amount of lawlessness and violence on the part of any portion of the population in Manchuria, or for the attacks of Chinese bandits in that region.

In the latter part of March, 1904, dispatches from St. Petersburg declared that Russia had demanded from China the dismissal of the Japanese military instructors in the Chinese army. Inasmuch as these appear to have been very few in number and as they had all been appointed several years prior to the outbreak of the war, this so-called violation of neutrality was, at the most, one of those "microscopic injuries" of which belligerents rarely complain.

During the months of March and April, I904, there arose a newspaper controversy regarding the neutrality of that portion of Manchuria which lies west of the Liao River, as also in respect to the neutrality of the treaty-port of NiuChwang, an important strategic point east of this river and one of the termini of the Northern China Railway system. It was in the region west of the Liao River that China's neutrality was "subjected to the severest strain and the closest scrutiny and criticism," as a writer in the Contemporary Review $w^{10}$ had predicted would be the case. This

${ }^{10}$ See article on "The Neutrality of China" by D. C. Boulger in the Contemporary Review for April, I904. 
region, like the rest of Manchuria, was fully occupied by Russia in consequence of the Boxer uprising in $1900 .{ }^{11}$ On April 8, 1902, Russia agreed to a gradual evacuation of Manchuria within eighteen months, and of this particular region within six months, although she reserved to herself the right to guard the Russian railways. According to this treaty, Russia agreed to the "reëstablishment of Chinese authority in Manchuria," which was to remain "an integral part of the Chinese Empire," and also consented to "restore to China the right to exercise sovereign and administrative powers." 12 This arrangement, however, was only partially carried out, owing, as Count Cassini claimed, ${ }^{13}$ to the "failure of China to furnish the required guarantees." The region west of the Liao River appears to have been the only portion of Manchuria which was actually evacuated by Russia. ${ }^{14}$ Niu-Chwang and Mukden, e. g., remained in her possession in spite of repeated promises to withdraw the garrisons from these cities.

"This region had, however, been practically, though not definitely, under Russian control since 1898, when China leased Port Arthur and. the Bay of Ta-lien to Russia, and at the same time granted her a railway concession through Southern Manchuria from Siberia, including the right to garrison and govern the territory along the line. A similar railway concession in Northern Manchuria had been obtained by Russia as early as 1896 .

${ }^{12}$ Art. I of the treaty. See Current History (XII, pp. $292 \mathrm{ff}$ ) for June, 1902.

${ }^{13}$ See article on "Russia in the Far East" by Count Cassini in North American Review for May, 1904.

${ }^{14}$ A portion of the Russian army seems, indeed, to have been withdrawn from the province and city of Mukden, but the remainder was simply stationed at important places along the Manchurian railways. In September, 1903, Russia undertook to restore Niu-Chwang and to evacuate Mukden on October 8, 1903, but this was never done; for, on December 28, 1903, the Russian Minister at Peking informed the Chinese Foreign Office that "no further steps towards evacuation can be undertaken at present." See Statesman's Year Book for 1904, p. 516. Cf. supra, pp. 33-34. 
China claimed that this region was neutral and included it in her Declaration of Neutrality. Russia, however, declined to respect its neutrality, and reoccupied the district, forbidding China to station troops within its borders. Yet, on the other hand, she appears to have shown a disposition to hold China responsible for the preservation of order in this territory, and is even said to have intimated that a landing of Japanese troops on its coast would constitute a violation of Chinese neutrality, for which China would be held responsible.

A great outcry was raised by the American Press in consequence of the proclamation of martial law at Niu-Chwang on March 27, I904. This outcry was probably aggravated by the indiscreet action of the Russian police authorities in ordering some American (and British) flags on certain private buildings at Niu-Chwang to be hauled down. The Russian authorities seem to have been clearly within their rights in this matter, but they wisely apologized for their action and the flags were restored to their former places upon the representations of the American consul. ${ }^{15}$

It was also reported that the foreign consuls at NiuChwang were notified that they were no longer to exercise consular jurisdiction and consular functions, especially those of extra-territorial jurisdiction, but this report does not appear to have been confirmed. It seems that certain of their functions, especially those comprehended under the term "extra-territoriality," were merely suspended, and that the foreign consuls continued to exercise such of their duties

${ }^{15}$ There seems to have been no protest at Washington. Of course, if the flag had been removed from the official residence of the consul, the case would have been different. A prompt and ample apology would have been necessary. 
as were compatiable with the execution of martial law. We do not recall that it has been customary to deprive consuls of their ordinary duties in time of war, but it could hardly be expected that they should be permitted to perform such service as would be inconsistent with the operation of military law.

In declaring martial law at Niu-Chwang, as also in occupying the region west of the Liao River with troops, Russia was clearly acting within her rights and was guilty of no violation of neutral rights or of the neutrality of China. This region forms a part of Manchuria, and was at least impliedly excepted from the application of the Hay Note, having been in the possession or under the control of Russia since I900. When Russia chose to reoccupy this region with troops in the early part of the struggle, all doubts as to its neutrality vanished and it became a part of the field of possible military operations for Japan as well as Russia; for it would be absurd for one belligerent to make military use of territory while claiming any part of it as neutral over against the other belligerent. ${ }^{16}$

In a Circular Note to the Powers, ${ }^{17}$ issued in January, 1905, Russia went so far as to threaten to "consider the neutrality of China from the standpoint of her own interests in case the actual situation in China, to which attention is now earnestly invited, shall continue." In this Note the Russian Government specified at least five distinct breaches of Chinese neutrality, viz.: (I) the Ryeshitelni incident; (2) the use of the Mia-Tao islands, which lie between Port Arthur and Teng-chow at the entrance of the Gulf of Pe-

${ }^{10}$ Russia seems to have made such claims in respect to the seacoast.

${ }^{17}$ This Note, being regarded as confidential, has not been made public, but an approved synopsis was given to the Press on January 17, 1905. 
chi-li, as a base for the Japanese fleet; (3) the operations of the Chunchuses or Chinese bandits on neutral territory under the command of Japanese officers (it was also charged that whole detachments of these bandits were enrolled in the Japanese army, that they were receiving regular pay for their services from the Japanese Government, and that Japanese instructors belonging to the Chinese military service occompanied the Chinese troops stationed on the northen province of $\mathrm{Pe}$-chi-li, professedly for the purpose of maintaining neutrality) ; (4) the frequent importation from Chinese ports of contraband of war into Dalny; and (5) the sale of iron ore from the Chinese Government factories at Han-yan to the Japanese for military use.

The Japanese, on their part, complained of the following violations of Chinese neutrality by Russia :-the constant violation of the neutrality of that portion of Manchuria west of the Liao River and of the treaty port of NiuChwang; the appropriation by Russia of Manchurian military stores and provisions; the chartering of the German merchant steamer Fooping at Che-Foo to carry Russian arms; the dispatch of 3,600,000 small-arm cartridges from Kalgan to Port Arthur; the establishment of wireless-telegraphy communication between Port Arthur and Che-Foo; the unwarranted delay of the Mandjur in disarming at Shanghai; the flight of Russian officers and sailors from the Ryeshitelni when they were supposed to be interned; and the aid extended at Che-Foo to Russian soldiers fleeing from Port Arthur.

The Chinese, in their turn, entered the following bill of particulars against Russia: the building of bridges and encampment of troops west of the Liao River, which, in their view, marked the boundary line of the neutral zone; the 
forced sale within the neutral zone of provisions to the Russians; the smuggling of arms, ammunition and other contraband articles by the Russians (presumably from China proper into Manchuria); and the escape from the Chinese authorities of the captain of the Ryeshitelni, while under military escort on his way to Shanghai.

The trivial nature of most of these allegations of the violation of Chinese neutrality on the part of Russia and Japan as well as of China is a matter of surprise, and many of them would scarcely deserve emphasis or serious discussion were it not for the magnitude of the interests involved and the great danger of international complications which existed at the time. The only really serious charge against Japan was the capture of the Russian torpedo boat destroyer Ryeshitelni, which had taken refuge in the Chinese port of Che-Foo on the night of August II, I904. This vessel was seized in this harbor and towed out on the night in question in spite of the fact that she was partially disabled and that she had been at least partly disarmed ${ }^{18}$ in accordance with the demand of the Chinese Admiral at CheFoo. This was an undoubted violation of Chinese neutrality and of the law of nations on the part of Japan, the seri-

${ }^{18}$ This was the case, at least, according to the statements of the Russian commander and Admiral Alexieff. But the fact of disarmament was denied by the Japanese Navy Department. For the official statements on both sides, see London Times (weekly ed.) for August 19, 1904. See also the New York Times for August 15. The fact that the Ryeshitelni was partly disarmed was practically admitted by $\mathrm{Mr}$. Takahira, the Japanese Minister at Washington, in an interview published in the New York Times for August 28, 1904. See also Count Cassini's interview in the New York Herald for August 19. For impartial reviews of the facts and law bearing on this case, see Smith and Sibley, pp. I $6 \mathrm{ff}$, and Lawrence, pp. $292 \mathrm{ff}$. 
ous character of which has in nowise been weakened by the specious grounds on which it has been defended.

The Japanese attempted to justify their action on the ground that China had failed to enforce her neutrality over against Russia, ${ }^{19}$ that the neutrality of China was plainly imperfect inasmuch as she was incapable of fulfilling her neutral obligations, and that, in the face of plain proofs of such incompetence, Japan was compelled to enforce her belligerent rights. It was also said that Japan did not intend to repeat the Mandjur farce, and that she could not afford to break up her fleet for the purpose of watching Chinese ports in which Russian vessels were abusing the privileges of asylum and taking advantage of China's inability to enforce neutral rights. ${ }^{20}$

Without examining the truth or seriousness of these charges, it is sufficient to observe that none of them, even if fully proven, would justify this violation of Chinese territorial sovereignty. One international wrong does not justify another, and there are other ways of obtaining redress for violations of neutrality, which are not too gross or serious, than that of an attack upon territorial sovereignty. As Daniel Webster, then (I84I) Secretary of State, said

${ }^{10}$ Amongst the breaches of Chinese neutrality by Russia were enumerated the constant violations of the neutrality of Chinese territory between the Great Wall and the Liao River, Russia's disregard of the neutrality of the treaty port of Niu-Chwang, the sinking of a British vessel, Hipsang, by the Russians, and the use by Russian agents of the port of Che-Foo as a base of supplies and military operations during the war. (It was claimed that Che-Foo had been used by Russia as a wireless telegraphy station, and that Chinese junks used this port as a base for the blockade of Port Arthur.)

${ }^{20}$ See Tokio correspondent to the London Times (weekly ed.) for August 19, 1904. For Japanese official statements, see House Doc. of 58th Congress, 3d session (For. Rel. for 1904), pp. I39 f and 425. 
in the case of the Caroline, ${ }^{21}$ in order to excuse such an act as the violation of neutral territorial sovereignty, one must "show a necessity of self-defense, instant, overwhelming, leaving no choice of means and no moment for deliberation." And as our most eminent jurist ${ }^{22}$ has well said in a famous case: "If there be no prohibition, the ports of a friendly nation are considered as open to the public ships of all Powers with whom it is at peace, and they are supposed to enter such ports and remain in them while allowed to remain, under the protection of the Government of the place." "It is the duty of the belligerent to refrain from the exercise of hostilities within the shelter of neutral territorial waters, ${ }^{23}$ and, if any vessel, whether belligerent or neutral, be assailed within such limits, it is incumbent on the neutral government in the first instance to defend her against her

${ }^{21}$ See Wharton's Digest, I, § $50 \mathrm{c}$.

${ }^{22}$ Chief Justice Marshall in Exchange v. McFaddon, 7 Cranch i 16.

${ }^{23}$ See the opinion of Sir W. Scott (later Lord Stowell) in the case of the Anna (5C Rob. 373), where it was held that the capture of an enemy's ship in neutral waters is illegal, and that such a vessel must be restored by the prize court of the captor. Sir W. Scott gave it as his opinion that this would be so even if the vessel had been pursued into neutral waters. Instances of the violation of neutral territory have not been altogether rare, even in the nineteenth century. They were perhaps the rule rather than the exception in the eighteenth century. The United States was guilty of at least two such violations during the Civil Warthe Florida in Brazilian, and the Chesapeake in British waters; but in both these cases the acts were disavowed and ample apology and reparation were made.

The case of the General Armstrong (see Wharton's Digest, II, § 227), in which Louis Napoleon acted as arbitrator in 1852, has been cited in support of the action of the Japanese, but the case is not at all analogous. Besides, although the decision was doubtless right, it appears to have been based on a wrong principle. In that case it was decided that the Portuguese Government could not be held responsible for the destruction of the American privateer General Armstrong in consequence of an attack by a British fleet in Portuguese waters in 18i4, inasmuch as the American vessel had begun the actual attack, and because her captain 
assailant, and, if she be captured, to exert itself to the utmost to effect restitution or otherwise to secure redress for the injury." ${ }^{24}$ Besides, there is no such status in International Law as that of imperfect neutrality.

The Japanese Government refused to offer any apology, disavowal or restitution for this gross violation of Chinese neutrality, and it must be admitted that her conduct in this matter, although altogether exceptional, constitutes a blot upon a record which was otherwise remarkably clean and spotless from the standpoint of International Law.

But, even granting the serious nature of this charge against Japan, it can not be admitted that the conduct of Japan on this occasion would have justified a violation of the neutrality or territorial integrity of China by Russia. As has been said, one international wrong does not justify another, and there are other ways of obtaining redress for violations of neutrality, than by an attack upon territorial sovereignty. Besides, China was in no wise responsible for this violation of her neutrality; and her Government, being under a pledge to keep the peace, seems to have done every-

had not applied "from the beginning for the intervention of the neutral sovereign." As Lawrence (Principles, p. 54I) points out, while this award was right, the principle of the decision was wrong in so far as it appears to support the broad doctrine laid down by some writers (see Hall, p. 628), that a "belligerent who, when attacked in neutral territory, elects to defend himself, instead of trusting for protection or redress to his host, by his own violation of sovereignty frees the neutral from responsibility." Whether we accept or reject the principle supposed to underly the decision of Napoleon in the case of the General Armstrong, it has no application in the case of the Ryeshitelni. In the latter case, Japan was clearly the actual as well as the real aggressor, and the Russian commander had placed himself under the protection of the Chinese Admiral, who proved to be a weakling or a coward.

${ }^{24}$ Walker, The Science of Int. Law, p. $45 \mathrm{I}$. 
thing possible under the circumstances to secure reparation and restitution.

The remaining charges of Russia against China and Japan are comparatively trivial, and some of them even puerile, in their character. The merest tyro in the study of International Law knows that it is not the duty of a neutral government to forbid the exportation from its ports of contraband of war or to prevent blockade running on the part of its subjects unless some of its ports are being used as a constant and regular base of supplies, in which case the neutral state would render itself liable to damages for any injury that might result to one of the belligerents.

The charges that Chinese brigands were commanded by Japanese officers and enrolled in the Japanese army and that Japanese military instructors were with the Chinese troops on the northern frontier of China, were declared by Japan to be without any foundation whatever. In its reply of January 24, 1904, to Secretary Hay's communication calling attention to the Russian charges that the Chinese were violating neutrality, the Government of China alleged that the Chunchuses were "enlisted first by the Russians as frontier guards" and that "they fought against the Japanese army." With respect to the possible enlistment of some of these brigands in the Japanese army, the reply pertinently states, "that is a matter for the belligerents, in the opinion of the Chinese Government. The subjects of a neutral power have the right as private citizens to enlist in a foreign army. This is an established fact in the law of nations for which China can not be held responsible." 25

With respect to the sale of iron ore to the Japanese, the

${ }^{25}$ For a fuller discussion of this subject of enlistment, see supra, ch. 2. 
Chinese Government claimed that the ore was "from certain mines owned by Chinese merchants, entirely separate from the Government mines at Hunyang," and that the transaction was "entirely between Japanese and Chinese merchants, and in fulfillment of a contract made in 1900."

Japan and China both denied that the Mia-Tao islands were used as a naval base by Japan, but the Japanese declared that Russia had so used the islands. We are not in a position to pronounce upon these alleged facts, but it would seem that for administrative purposes these islands were held by the Chinese Government to be an appurtenance of the adjoining portion of the Liao-tung Peninsula. This would make the use of these islands by the Japanese navy a venial offense. If they had any value as a naval base, their proximity to the theater of naval operations would have made the temptation to use them for military purposes too strong to be resisted.

The charges of Japan and China against Russia are, with the exception of the Ryeshitelni incident, more serious than those of Russia against China and Japan, although they were hardly of such a character as to have justified Japan in violating her agreement with the Powers, or to have called for intervention. The most serious charge is that which relates to the violation of the neutrality of NiuChwang and the neutral zone west of the Liao River. As stated above, this region is, indeed, an integral portion of Manchuria, which, by the common consent of all concerned, was exempted from the application of the principles of the Hay Note (at least so far as the neutrality of China was concerned); but it seems to have been wholly evacuated by the Russians prior to the outbreak of the war and to have been included by China in her Declaration of Neutrality. 
Japan appears to have respected the neutrality of this district, but Russia was charged by the Japanese with the maintenance of a large force, and by the Chinese with the building of bridges, the encampment of troops, and the forced sale of provisions in this territory. In a raid upon the Japanese southwest of Liao-Yang and a descent upon Niu-Chwang early in the year 1905, General Mischenko and his Cossack cavalry likewise appear to have violated the neutrality of this region, which could, therefore, no longer be regarded as outside the theater of war or area of hostilities. The same arguments apply here that have been urged in the case of the Mia-Tao islands. This district appears on the map as a part of the province of Sheng-king, the southern province of Manchuria, and its proximity to the theater of war made the temptation to use it for military purposes well-nigh irresistible.

The erection and use of a wireless-telegraphy station at Che-Foo by the Russians for the purpose of communication with Port Arthur, which seems to have been permitted by the Chinese authorities until the end of August, I904 (when the station was demolished by the Chinese), shows that the Chinese Government was at first either ignorant of the obligations of neutrality in this respect or too lax in enforcing them. This was undoubtedly a case of the use of neutral territory by a belligerent for a military purpose; but the use of wireless telegraphy stations on neutral territory raises a new question in International Law which must be decided by the analogy of the law relating to submarine cables (which is also of comparatively recent origin), so that the Chinese should not be judged too harshly in this matter. If the Japanese could prove that they were seriously injured by the transmission of wireless messages between 
Che-Foo and Port Arthur, they would probably be entitled to damages.

The Japanese also seemed to think that they had a serious grievance in the delay of the Mandjur to disarm at Shanghai during the first two months of the war, but the rule of International Law which has generally been supposed to govern such cases is by no means as clear and undoubted as the Japanese appear to have imagined. It is true that a series of new precedents was created during this war in favor of the view that belligerent armed vessels remaining or seeking refuge in neutral ports ought to be dismantled and disarmed, and their crews paroled or detained until the end of the war, as in the analogous case of defeated or fugitive troops seeking refuge from pursuit on neutral territory in warfare on land. ${ }^{26}$ It is also doubtless true that the conduct of the Chinese Government was weak and vacillating in the case of the Mandjur, and still more so in the later cases of the Askold and Grosvoi; but it is only within recent years that neutral governments have become more fully alive to their neutral duties in these respects, and of all states China could hardly be expected to create precedents or prefer the new to the old.

Our review of the most important examples of alleged violations of Chinese neutrality, whether by the belligerents or by China herself, has shown us how trivial, and even puerile, comparatively speaking, most of these charges really are. The very insignificance and triviality of many of them prove that, considering all the conditions in which she found herself and the circumstances by which she was surrounded, China was reasonably successful in the mainte-

${ }^{26}$ See supra, pp. $21 \mathrm{I}$ n. and 216. 
nance of her neutrality and the performance of her neutral duties. In any case, she deserved to be treated with great leniency, especially by Russia, because of the serious difficulties of her anomalous position and her military and administrative weakness. For this weakness and these difficulties Russia was, in a measure, responsible. None of the alleged violations of Chinese neutrality were of such a serious or dangerous character that they might not have been settled by diplomacy or arbitration, or, as Secretary Hay suggested in a note to Count Cassini, by a Conference of the Powers. In international, as well as in other relations, prevention is often better than cure, and the Hay Note, backed up by subsequent representations, must be held to have at least contributed toward the prevention of serious violations of Chinese neutrality and to have thereby aided in preventing serious international complications leading to a possible international catastrophe. The threat of Russia to absolve herself from her agreement with the Powers by an ex parte decision of all questions relating to Chinese neutrality was pretentious and absurd and might, if not resisted, have led to such a catastrophe. 


\section{CHAPTER X}

Russian and Japanese Rules of Warfare

On February 28, 1904, the Russian Government issued an Imperial Order laying down the following rules of warfare to be observed by Russia during the war:

r. Japanese subjects are authorized to continue, under the protection of Russian law, to reside and to follow peaceful callings in the Russian Empire, except in the territories forming part of the Imperial Lieutenancy in the Far East.

2. Japanese merchant-vessels which, at the time of the declaration of war, happened to be in Russian ports and harbors, are authorized to remain there before putting to sea with cargoes not being articles contraband of war, for such period as may be necessary in proportion to their loading requirements, but which shall in no case exceed forty-eight hours, counting from the moment that the present declaration is published by the local authorities.

3. Subjects of neutral states may continue without hindrance their commercial relations with Russian ports and towns, provided that they conform to the laws of the Empire, and to the principles of the law of nations.

4. The military authorities are bound to take all necessary measures to secure freedom for the lawful trade of neutrals so far as is compatible with war-like operations.

5. The following rules are to be observed with regard to neutral commerce:

(I) The neutral flag covers enemy's goods, with the exception of contraband of war.

(2) Neutral goods, with the exception of contraband of war, may not be seized under the enmy's flag. 
(3) Blockade, in order to be binding, must be effective; that is to say, it must be maintained by a force really sufficient to prevent access to the enemy's coast.

6. (Enumerates articles deemed to be contraband of war. See supra, ch. 6.)

7. The following acts, forbidden to neutrals, are assimilated to contraband of war: The transport of enemy's troops, of his dispatches and correspondence, the supply of transports and war-ships to the enemy. Neutral vessels captured in the act of carrying contraband of this nature may, according to circumstances, be seized, and even confiscated.

8. The Imperial Government reserve to themselves the right to depart from the above-mentioned regulations in regard to an enemy or neutral state which, on its side, does not observe them, as well as to take the necessary measures in accordance with special circumstances of each specific case.

9. The detailed regulations which the military authorities are bound to observe during naval warfare are set forth in the "Reglement" relating to prizes sanctioned by His Majesty, the Emperor, on the 27th of March, I895, as well as in the special instructions approved by the Admiralty Council on the 2oth of September, 1900, relating to stoppage, visit, capture, transport, and delivery of captured vessels and goods.

Io. In addition, the military authorities are bound to conform to the following International Agreements signed by Russia :

(I) The Geneva Convention of the roth (22d) August, I864, for the amelioration of the condition of the wounded in time of war.

(2) The Declaration of St. Petersburg of the 29th November (I Ith December), I868, respecting the prohibition of the use of explosive projectiles.

(3) Agreements signed at the International Peace Conference at the Hague, the I7th (29th) July, I899, and ratified by His Majesty, the Emperor, the 6th May, r9oo.

(a) Convention with respect to the laws and customs of war by land. 
(b) Convention for adapting to maritime warfare the principles of the Geneva Convention of the Ioth (22d) August, I864.

(c) Declaration relating to the prohibition of the use, for a period of five years, of projectiles and explosives dropped from balloons or by means of other similar new methods.

(d) Declaration relating to the prohibition of the use of projectiles which are only intended to spread asphyxiating or noxious fumes.

(e) Declaration relative to the prohibition of the use of bullets which expand or flatten easily in the human body, such as bullets with hard casing, of which the casing does not entirely cover the core, or is provided with notches. ${ }^{1}$

On July I4, I904, the following "Instructions" to the

${ }^{1}$ Reprinted from the Parliamentary Blue Book on Russia, No. I (1905), pp. 4-5.

${ }^{2}$ For the French version from which this translation has been made, see Archives Diplomatiques, t. 94, 3d series, Vol. II (1905), pp. $500 \mathrm{ff}$. There were also distributed to the Russian armies the following texts: that of the Convention of Geneva of 1864 ; the Declaration of St. Petersburg of 1868; and the "Regulations Respecting the Laws and Customs of War on Land" of the Hague Conference of 1899 , together with the three Declarations thereto annexed. See Holls, Peace Conference, ch. 4 and Appendix I, pp. 423-463, for the Hague Regulations. Art. I of the Second Hague Convention (Holls, pp. I39 and 4I9), to which the Regulations are merely an annex, declares that the "High Contracting Parties shall issue instructions to their armed land forces, which shall be in conformity with the 'Regulations Respecting the Laws and Customs of War on Land' annexed to the present Convention." It is thus not quite clear whether the Hague Regulations are in themselves binding upon the "High Contracting Parties" or not. M. Renault, the Chairman and Reporter of the Second Committee of the Hague Conference, was of the opinion that they are obligatory, in spite of the somewhat peculiar mode of their adoption-a procedure which, as it seems, was adopted so as not to arouse opposition on the part of certain delegates who appeared to doubt the propriety of giving formal sanction to a body of rules which by their very restrictions implied the recognition of certain belligerent rights. The Russian De Martens, on the other hand, spoke of the Hague Regulations as forming the "solid basis for the instructions which the Governments should hereafter, in case of war, issue to their 
Russian Army Respecting the Usages and Customs of Continental War" were ratified by the Czar:

\section{INSTRUCTIONS TO OFFICERS}

\section{(I) Belligerents}

I. In time of war the regular troops of the enemy, the militia and the volunteer corps are considered as belligerents.

2. Volunteer corps and militia should be considered as belligerents only if they are commanded by a leader responsible for his subordinates, if they have very distinctive external badges, if they carry arms openly, and if they observe the laws and customs of war in their operations.

3. The inhabitants of an enemy country who have taken up arms upon the approach of our army, but who have not had sufficient time to organize themselves into volunteer corps, may be considered as belligerent if they observe the laws and customs of war in their operations. ${ }^{3}$

\section{(2) Non-Belligerents (Les Neutres) 4}

4. Field ambulances and military hospitals are recognized as neuter (non-belligerent, inviolable), but only at a time when there are sick or wounded in them.

arms on land." Holls, p. 136 . See especially the comments of Pillet, Les Lois Actuelles de la Guerre. $2 \mathrm{~d}$ ed., pp. 452 ff. Holland (The Lawe and Customs of War on Land, p. 2) appears to be of the opinion that the text is not binding.

${ }^{8}$ These articles correspond almost literally with Arts. I and 2 of the Hague Regulations, and with Arts. 9 and ro of the Rules of the Brussels Conference. Art. 3 of the Hague Regulations (or Art. II of the Rules of the Brussels Conference), which provides that non-combatants as well as combatants are to be treated as prisoners of war in case of cap. ture, is omitted in the Russian "Instructions."

- The instructions under this head are based upon Arts. I-4 and Art. 7 of the Geneva Convention of 1864. For Arts. 5 and 6 of the Geneva 
This neutrality ceases if the ambulances or hospitals are guarded by a military force.

5. Convoys of wounded and all persons indispensable for conveying them enjoy the right of neutrality.

6. The entire sanitary personnel of field ambulances and hospitals, namely, physicians, officials, nurses, the attachés of sanitary convoys, army chaplains, enjoy the privilege of neutrality during the exercise of their duties.

7. The persons mentioned in the preceding article are free to continue the exercise of their duties and to rejoin their army during the occupation of the enemy's country by our army.

The authorization to rejoin their army must emanate from the corps commander. These persons are to be escorted to the enemy's outposts.

The movables of field-hospitals and pest-houses remain in the possession of the occupying army; this is why the persons attached to these services of sanitation may, in leaving, take with them only their personal belongings.

It is forbidden, however, to take possession of the furnishings of an ambulance designed to follow the troops upon the battle-field.

8. Hospitals, pest-houses and convoys of wounded soldiers shall carry the Red Cross flag.

The entire medical and sanitary personnel of these services shall wear a white arm badge marked with a red cross.

\section{(3) The Rights and Duties of Belligerents}

9. The troops should respect the life and honor of the inhabitants of the enemy's country, their property and family rights, and also their religion and their creed.

Io. They are permitted to take possession of movables belonging to the belligerent state and serving a military purpose, such as money, stores of arms and ammunition, material for dressing wounds, etc.

Convention, see Arts. 2I-24 of the "Instructions." For the text of the Geneva Convention, see Wilson and Tucker, App. IV, pp. 395 ff. 
Beyond this, the troops may take possession of material for railways, telegraphs, telephones, steamboats and other vessels, as also of military stores belonging to companies or to individuals.

II. In the course of military operations, the following things are prohibited:

(a) the use of poison or of poisoned arms, with intent to injure the enemy, as also the use of arms, machines, and materials which may cause useless suffering;

(b) to declare that no quarter will be given;

(c) to make an unlawful use of a flag of truce or of the national flag, of military signals, or of the enemy's uniform;

(d) to show, in order to deceive the enemy, the flag or badge of the Red Cross;

(e) to destroy or to take possession of things belonging to the enemy with the exception of those cases: (I) mentioned in Art. Io; and (2) when military considerations demand it;

(f) to attack and bombard towns, villages, habitations and buildings not occupied by the enemy or by his stores of war material;

(g) to pillage inhabited places, even those taken by assault.

12. All pillage is rigorously prohibited under penalty of the severest punishment (the penalty of death being included).

I3. The capture, destruction, or premeditated injury of property of institutions devoted to purposes of religion, beneficence, education, art and science, as also of historical monuments, are prohibited.

I4. It is the duty of the commander of a detachment to announce to its inhabitants his intention to bombard a place, unless the necessities of war prevent such a course (e. $g$., in the case of a sudden or an unexpected attack).

15. During sieges and bombardments measures should be taken to preserve, as far as possible, the temples and the edifices used as museums, schools, asylums, hospitals, or edifices used for sheltering the wounded, provided said places are not used at the same time for military purposes. 
All the places above mentioned should be marked by special signs which should be made known to the besieger in time.

I6. It is forbidden to force the population of occupied territory to take part in military operations against their own country, as also to compel them to take the oath of allegiance to a hostile power.

17. Contributions (payments in money) can only be exacted by virtue of an order from the commander-in-chief of the army. The troops are required to give receipts for such payments.

I8. Requisitions (compulsory supplies) in kind or in services can only be imposed on the population upon the author $r$ ization of the commander-in-chief of the army or of the chief of the military administration of the district commanding, $a d$ interim, the troops of the district, and, in case of urgency, upon the authorization of the corps or division commander.

19. The services should not be of such a nature as to oblige the local population to take part in the military operations against their country.

20. The supplies and services are to be paid for as far as possible in cash; otherwise the troops are expected to give receipts (signed and sealed by the chiefs of detachments and companies $).{ }^{5}$

- The above rules comply in a general way with the requirements of the Regulations of the Hague Convention contained in Arts. 23-29 and 42-57. They are more specific in some cases and less so in others. On the whole, it must be said that the Russian "Instructions" fall somewhat short of the requirements of the Hague Convention, especially in the omission of Arts. 42, 43 and 48 of the Hague Regulations relating to the law of military occupation. Arts. I7 and 18 of the "Instructions" must be pronounced very unsatisfactory and inadequate in view of the fact that it is not stated that war requisitions and contributions should not be in excess of military necessity and that requisitions "must be in proportion to the resources of the country." See Arts. 49 and 52 of the Hague Regulations. The substitution of the word "occupied" for "defended" in Art. II $f$ of the "Instructions" (see Art. 25 of the Hague Repulations) may be an oversight or an error, but it changes considerably the scope of the right of bombardment. 


\section{(4) The Wounded}

2 I. Sick and wounded soldiers are to be gathered regardless of the army to which they belong.

22. The exchange of the wounded can only take place upon the authorization of the commander-in-chief of the army, and in accordance with an understanding arrived at between the two belligerents.

The convalescent sick and wounded of the hostile army, after their complete recovery, shall be sent back to their own country, if they are regarded as unfit for service; the others can only be returned on condition that they promise not to take up arms again during the war.

23. The commander of the troops should instruct the inhabitants that it is their duty to lend succor to the wounded of both belligerents; those of the inhabitants who accept the wounded are exempt from the obligation of quartering soldiers, and also from a part of the war contribution.

24. After a battle, the chiefs of detachments and the military authorities are required to take such measures as may be necessary to prevent our wounded, as also those of the enemy, remaining upon the battle-field, from being plundered. Those who are found guilty of forcibly plundering the wounded shall be judged as though guilty of an act of brigandage. ${ }^{8}$

"Arts. 2I, 22 and 23 of the above "Instructions" correspond in the main to Arts. 5 and 6 of the Geneva Convention of 1864 . The Additional Articles of 1868 are not binding, as they never received the formal sanction of the Powers. Besides, it is generally conceded that they are defective and deficient in some respects. The principles of the Geneva Convention of 1864 were adapted to the needs of maritime warfare by . the Hague Conference of I899. See Holls, ch. 4, pp. I2I-I3I and pp. 463473. These Conventions still remain the sole source of international legislation on the subjects of which they treat. Among the pious wishes (vaux) expressed by the Hague Conference was one for the assembling, in the near future, of a special Conference having for its object the revision of the Geneva Convention of I864. Holls, p. 377.

Article 24 of the Russian "Instructions," which is strongly to be commended, contains nothing in excess of what is required by military discipline as well as by International Law. 


\section{(5) Prisoners of War}

25. Non-combatants, as well as combatants, may be made prisoners; both are regarded as prisoners of war.

26. If made prisoners and it is found necessary to detain them, newspaper correspondents, sutlers, contractors, etc., who are provided with certificates from the military authorities of the army to which they are attached, shall enjoy the rights of prisoners of war.

27. The duties of receiving, maintaining, and guarding the prisoners, as also their convoy, falls upon the corps commanders, and are to be performed under the direction of the staff officers of the corps.

28. Prisoners of war should be treated with humanity, and they should be allowed entire freedom of worship. They shall be subject to the same treatment as that given to soldiers of the Russian army.

29. Every prisoner is bound to declare his true name arid rank; in case of violation of this rule, he must submit to a restriction of the privileges reserved for prisoners of his class.

30. Prisoners of war are subject to the laws, regulations, and ordinances in force in the army which has captured them; and, in case of insubordination, severe measures may be applied to them.

3I. The commander of the armed detachment which forms the convoy of the prisoners is considered the chief of sentry and he should conform to the regulations for garrisons (Articles I98-210).

32. All their personal belongings, except arms, horses, and military papers, shall remain the property of the prisoners.

33. A prisoner who has succeeded in escaping should not be punished in case he is made prisoner a second time; but the surveillance shall be made more rigorous.

34. Escaped prisoners, who are recaptured before having rejoined their army, are merely liable to disciplinary punishment for having escaped. 
35. The wills of prisoners are to be drawn up and preserved, in conformity with the common law.

36. In case of the death of a prisoner of war, a record of it shall be made and, at the time of the obsequies, proper regard shall be paid to his rank and titles.?

\section{(6) Bearers of Flags of Truce}

37. Every person who is authorized by one of the belligerents to carry a white flag and to enter into communication with the other belligerent, is considered a bearer of a flag of truce.

The bearer of a flag of truce and his suite are inviolable, namely: (a) the trumpeter (drummer, bugler); (b) the flagbearer; (c) the interpreter.

38. The commander to whom the bearer of a flag of truce is sent shall decide whether to receive him or not.

39. All necessary measures may be taken to prevent the bearer of a flag of truce from taking advantage of his mission to obtain information.

"The above "Instructions" regarding the treatment of prisoners of war are, generally speaking, in conformity with the requirements of the Hague Regulations (Arts. 4-2I); but they are less detailed, and there are some omissions. For example, there is nothing said as to the labor and wages of prisoners (see Art. 6 of the Hague Regulations), and there is no provision for the organization of a Bureau of Information such as is provided for by the Hague Convention. (See Arts. 14-17.) This omission led to considerable complaint during the war on the part of the Japanese, who scrupulously observed all the requirements of the Hague Convention.

On the proper treatment of prisoners of war, see also, for purposes of comparison, the American "Instructions," Arts. 49-50, 56, 72-82, 105IIO, II9-I33; the Rules of the Brussels Conference, Arts. 23-35; the Oxford Code or Manual adopted by the Institute of International Law, Arts. 2I-22 and 6I-78; and the French Reglement du $2 \mathrm{I}$ Mars, I893, sur les prisonniers de guerre. The French Regulations, which are the most liberal and detailed I have seen dealing with this subject, are printed in the Revue Générale de Droit International Public for 1894, Documents, pp. Io-30. The other documents may be found in the appendices to Snow's Cases and to Wilson and Tucker's International Law. 
If it be observed that the bearer of a flag of truce is guilty of such abuse, he may be detained provisionally.

40. The bearer of a flag of truce loses the right of personal inviolability if it be proven that he has taken advantage of his privileged position to provoke treachery.

4r. The act of raising a white flag during a battle should not stop the military operations; but the bearer of the white flag and his suite should not be fired upon. When the bearer of a flag of truce approaches our fighting lines, he must be directed to the chief to whom he is sent or to a superior commander. It is only when the enemy's troops lay down their arms or fulfill the conditions stipulated for that the battle shall cease. $^{8}$

\section{(7) Spies}

42. An individual who, acting secretly or under false pretenses, tries to obtain any information in the zone of our operations with the intention of communicating it to the enemy, is considered a spy.

43. Spies can only be punished in pursuance of a sentence.

44. The following are not considered spies:

(I) soldiers not in disguise who have penetrated into the zone of operations of the belligerent to obtain information;

(2) soldiers or civilians who carry out their mission openly and are charged with transmission of dispatches destined either for their own army or for that of the enemy;

(3) persons sent in balloons to maintain communications between the various parts of an army or a territory. ${ }^{\circ}$

${ }^{8}$ Cf. Arts. ${ }^{32-34}$ of the Hague Regulations. Art. $4 \mathrm{I}$ of the Russian "Instructions" is not included in the Hague Regulations; but Art. 112 of the American "Instructions" states that "firing is not required to cease on the appearance of a flag of truce in battle." The Oxford Code (Art. 29), the Rules of the Brussels Conference (Art. 44), and the Hague Regulations (Art. 33) all state that "the commander to whom a flag of truce is sent is not obliged to receive him under all circumstances."

' $C$. Arts. 29-3r of the Hague Regulations. Art. 3r of the Hague Regulations is omitted. It provides that a spy, who has rejoined his 
I. You are to wage war with the troops of the enemy and not with the peaceable inhabitants.

The inhabitants of the enemy country may also be enemies, but only in case they are seen with arms in their hands.

2. Strike the enemy in loyal combat. Do not strike the enemy who is disarmed and who begs for quarter.

3. Respect foreign religions and temples.

4. Do not injure the peaceable inhabitants of the enemy country; do not take away nor injure their goods, and restrain your comrades from doing these things. Cruelties toward the inhabitants only increase the number of our enemies. Remember that the military man is the soldier of Christ and of the Czar; this is why he should conduct himself like a Christian soldier.

5. After the battle is ended, you should be considerate of the wounded and try to aid them without distinguishing whether they are our own people or not. The wounded are no longer enemies.

6. Treat prisoners with humanity. Do not rail at their faith; do not oppress them; do not meddle with their belongings.

7. The plundering of prisoners, and, still worse, of the wounded and killed, is a lasting disgrace to an honest soldier; one who permits himself to commit such an action is liable to the severest penalties, as though he had committed an act of brigandage.

8. If prisoners are entrusted to you, prevent people from addressing them. If the prisoner attempts to escape, stop him, call for aid, and, as a last resort, have recourse to arms.

9. Tents and houses in which the wounded are kept are al-

army and is subsequently recaptured, shall be treated as a prisoner of war. 
ways designated with a white flag marked with a red cross. Do not fire upon these places, and do not enter them forcibly.

Io. Do not meddle with people, even those carrying the enemy's uniform, if they wear a white arm badge marked with the red cross, for they take care of the sick and wounded.

II. If you perceive an enemy carrying a white flag, do not fire upon him, but send him to your chief; he is the bearer of a flag of truce, a person who is inviolable.

On February 9, 1904, the Japanese Government issued an Imperial Ordinance exempting Russian merchant-ships from capture in the following cases $:^{10}$

ART. I. Russian merchant ships which happen to be moored in any Japanese port or roadstead at the time of the issue of the present rules, may discharge or load their cargoes and leave the country not later than February 16, 1904.

2. Russian merchant ships which have left Japan in accordance with the foregoing article shall not be captured if they can prove by certified documents that they left the ports and roadsteads of Japan after having discharged or loaded their cargoes before the expiration of the delay granted by the foregoing article, and that they are steaming towards the nearest Russian or leased port or to their original destination. This exemption shall not, however, apply in case such a ship has once touched at a Russian port or at a leased port.

3. Russian merchant ships which have left foreign ports or roadsteads for a Japanese port or roadstead before February I6 may enter our ports, discharge their cargoes at once, and leave the country. Russian merchant vessels coming under the above category shall be treated in accordance with Article 2.

4. This ordinance shall not be held to apply to Russian merchant ships having on board objects of which the exporta-

${ }^{10}$ For the French text, see M. H. Nagaoka in Revue de Droit International et Leg. Comp. for 1904, pp. 494-95. For an English translation which I have tried to correct with the aid of the French version, see House Doc., 58th Congress, 3d session (For. Rel. I904), pp. 414-15. 
tion is forbidden, whether persons, objects or documents of contraband.

On February I0, 1905, the Japanese Minister of the Interior issued the following Instructions ${ }^{11}$ to the general Government of Tai-wan, etc. :

"Having been obliged to its great regret to declare war against the Russian Empire, the Imperial Government (of Japan) by no means intends to show itself hostile to the subjects of that nation. Those among them who actually happen to be in Japanese territory will be permitted to continue to reside here; those who shall come here will not be expelled, and those who may wish to leave will not be prevented from doing so. They will all be protected in their lives, honor, and property in accordance with the text of our laws and ordinances. They will be allowed to attend quietly to their own affairs and to ask for the protection of the imperial tribunals. This should, however, be considered as an act of grace on the part of the Imperial Government. Consequently, it will permit no restrictions in the execution of necessary administrative acts of surveillance and of measures taken by the military or naval authorities for military purposes and it may in part restrict the guarantees in respect to persons, their lives and property. Besides, it may prohibit or limit travel or changes in domicile, if it be considered necessary. Thus, those who, in spite of the favor granted by the Imperial Government, serve their country in respect to its military interests, or who threaten the safety, order, or the good customs of the Empire, or who commit any other acts injurious to the interests of the Empire, may be made the objects of special measures in accordance with our laws

\footnotetext{
"See Nagaoka, op. cit., pp. 480 ff. As Nagaoka remarks, these instructions are very similar to those given in 1894 in favor of Chinese subjects. Although the ordinance of August 4, 1894, required registration on the part of the Chinese, this was because of the greater number of Chinese subjects in Japan at that time. For the decree of August 4, I894, see Ariga, La Guerre Sino-Japonaise, pp. 23-25.
} 
and ordinances, and may even receive an order to leave the Empire at once. Those who, having no means of existence, are forced to apply for public charity, may also learn that they are forbidden to reside in the Empire. In one word, to every subject of the Russian Empire residing in Japan there will be granted the greatest protection possible within limits not injurious to the interests of the Empire. It will be expected that Russian subjects be treated in accordance with this spirit and that care be taken that Japanese subjects do not create misunderstandings upon this point."

The same day (February I0, I904) the Minister of Public Instruction addressed a note to the school teachers of Japan in which he asked them not to encourage chauvinism (jingoism) and in which he recommended the following mode of conduct toward Russian subjects : ${ }^{12}$

"Although the Imperial Government is at present at war with Russia with the purpose of later securing a permanent peace, the students and pupils should make it their special aim to show themselves in no wise hostile toward Russian subjects. Such hostility on their part would give foreign nations a bad opinion of us. Besides, this is an important point to be considered in the education of boys and girls."

On February I9 the Minister of the Interior, in his instructions to the heads of the various Shinto and Buddhist sects in Japan, said in respect to religious freedom $:^{13}$

"Although diplomatic relations between Japan and Russia are suspended, there is no reason for showing ourselves hostile toward Russian subjects and especially should there be no change in our attitude in respect to the equality and liberty of religions. This is an important point to which those who are

${ }^{12}$ Nagaoka, op. cit., $48 \mathrm{r}$.

${ }^{13}$ Ibid. 
engaged in religious propaganda and mission work should give their careful attention. The heads of the various faiths are requested to ask their clergy to pay special attention to these instructions."

On February 14, I904, the Japanese Minister of War issued a list of "Regulations Relative to the Treatment of Prisoners of War," consisting of thirty-four articles. ${ }^{14}$ We do not deem it necessary or advisable to reproduce them here, partly because of their length, but mainly because most of their important or distinctive features are more clearly and fully repeated in later "Instructions." They provide, e. $g$., that prisoners are to be treated with humanity (i.e., not to be maltreated or insulted) and in conformity with their rank (Arts. 2 and 3 ) ; they shall enjoy liberty of conscience and freedom of worship (Art. 5) ; if possible, they shall have separate rooms in accordance with their position and rank (Art. 23) ; if convenient, they shall be furnished with such articles of use or luxury as they may wish to purchase (Art. 24); sick and wounded prisoners who are vouched for as incapable of further military service, are to be sent back to their own country on parole after they have been properly cared for in hospitals or ambulances (Art. 28); all articles belonging to prisoners shall be returned to them as soon as they shall have obtained their liberty, and all articles left by deceased prisoners, as also all wills, shall be sent to the Bureau of Information for prisoners of war (Arts. 29, 30 and 31 ) ; prisoners shall be permitted to receive money or articles sent directly to them, as also any aid from benevolent associations, after proper precautions

${ }^{14}$ For the French text of this "Reglement," see Nagaoka in Revue Générale de Droit Int. Pub. for 1905, pp. 605 ff. 
have been taken to prevent any abuse of such privileges (Arts. $3^{2}$ and 33 ), etc. As may be seen from the above partial synopsis of their contents, these regulations were conceived in the most advanced, humane, and liberal spirit. ${ }^{15}$

On February 19 the Japanese Minister of the Navy issued the following additional Instructions ${ }^{16}$ in respect to the treatment of prisoners of war:

I. All objects found in the possession of enemy combatants made prisoners or who are considered as such by virtue of treaties or the customs of war will be examined.

2. Arms, ammunition and other things of use in war found in the possession of a prisoner will be confiscated; but every other object may, according to circumstances, be left in his possession or taken away from him. ${ }^{17}$

The officers and civil functionaries assimilated to officers may also, according to circumstances, be allowed to keep their sabres and other arms, on condition, however, that the firearms be discharged.

${ }^{25}$ On September 10, 1904, the Japanese Minister of War issued additional rules regulating the kind and amount of labor which might be required from prisoners of war. Article I provides that "prisoners of war might be required to work for governmental or public establishments, corporations or individuals according to their rank, situation, or capacities," but that officers can not be forced to labor against their own will. Such work must not be excessive or humiliating to those engaged in it. (Art. 3.) In case prisoners are employed by the governmental establishments, the soldiers are to receive four sen (nearly two cents) and the non-commissioned officers and civil functionaries seven sen per diem. (Art. 5.) Prisoners may be authorized to work for themselves (Art. 2), but in this case the proceeds (whether in the form of money or product) are to be turned over to treasurers of the establishment where the prisoners are kept and the expenses of nourishment and maintenance shall be deducted from the amount credited to each prisoner. (Arts. 6-8.) See Nagaoka, op. cit., pp. $608 \mathrm{f}$.

${ }^{16}$ For the French version of which this is a translation, see $M$. $H$. Nagaoka, Revue de Droit Int. et de Leg. Comp. for 1904, pp. 497 ff.

${ }^{17} \mathrm{Cf}$. Arts. 4 of the Hague Regulations and 32 of the Russian Instructions. 
3. After the two foregoing articles have been executed, the prisoner will be questioned in respect to his age, position, rank and nationality; then the list of prisoners and of articles confiscated and taken away will be drawn up.

4. Prisoners of war will be divided into officers and civil functionaries assimilated to officers and into non-commissioned officers and soldiers, and each prisoner will be treated according to his rank. This, however, will not be the case with those who do not tell the truth when interrogated or who commit other violations of the regulations.

5. Prisoners of war who commit a breach of discipline may be interned, imprisoned, or made the object of any other severe measure.

In case of an attempt to escape even armed force may be used to prevent it, if it be considered necessary.

(Articles 6, 7, 8, and 9, deal with the disposition and distribution of prisoners of war and are omitted.)

Io. The place in which prisoners are kept shall be guarded by sentinels under the supervision of a naval officer.

II. If a prisoner ask permission to buy, at his own expense, an article of use or luxury, he may be allowed to do so if the attendant sees therein no inconvenience. In this case he may be allowed all conveniences which he can procure for himself.

12. The prisoners may send or receive letters and dispatches after these have been examined by the officer in attendance. All suspicious communications or messages in cipher should be confiscated or prohibited.

13. The naval authorities shall, in co-operation with the local postal officials, take such measures as may be necessary in respect to all postal articles which are destined for prisoners or sent to them, and which enjoy free postage according to conventions. ${ }^{18}$

${ }^{18}$ This article refers to Article 16 of the Hague Regulations, which deciares that "letters, money, orders, and valuables, as well as postal parcels destined for the prisoners of war or dispatched by them shall be free from all postal duties, both in the country of origin and destination, as well as in those through which they pass." 
I4. The wills of prisoners shall be subject to the same conditions as those of men belonging to the navy. ${ }^{19}$

I5. At a place pointed out to the agents of the land army who are charged with the delivery of prisoners, the naval prefect shall deliver the articles taken from these prisoners together with all documents as well as wills and articles left by deceased prisoners before their demise. ${ }^{20}$

The text of Article I 3 of the above Regulations being deemed insufficient, the Japanese Minister of Ways and Communications issued, on March 3, 1904, the following "Postal Regulations for Prisoners of War:"21

I. By postal articles in these regulations are meant internal or international postal articles, whether destined for the Bureau of Information for prisoners of war or whether intended for the prisoners themselves or sent by them.

2. All postal articles concerning prisoners of war, excepting those coming under the head of these regulations, shall be subject to the general rules for the internal or international postal service.

3. Those sending postal articles to prisoners of war should indicate the following on the address: "Service for Prisoners of War."

4. The postal articles of prisoners of war are free from all postal duties, in conformity with conventions.

5. The receipts for postal articles recommended, or for ordinary postal articles with a declared value, or of postal packages destined for prisoners of war or sent by them, will be de-

10 This article was inspired by Article ig of the Hague Regulations, which declares that "the wills of prisoners of war shall be received or drawn up on the same conditions as for soldiers of the national army." Cf. Art. 35 of the Russian Instructions.

${ }^{20}$ In the French text, the last word is remise, which is evidently a misprint. The context shows that demise is meant.

${ }^{21}$ Nagaoka, op. cit., pp. 499-500. 
livered by the intendant of the establishment for the interning of prisoners of war or entrusted to this intendant.

On the same day (March 3, r904) the Minister of Ways and Communications issued similar regulations relating to postal orders for prisoners of war $:^{.2}$

I. By a postal order in these regulations is meant the ordinary postal or international postal order destined for prisoners of war or sent by them.

2. All postal orders concerning prisoners of war, excepting those coming under the head of these regulations, shall be subject to the general rules for internal and international postal orders.

3. Postal orders concerning prisoners of war shall be free from all duties, in conformity with conventions.

4. One sending a postal order to a prisoner of war should request the postal bureau from which the order is sent to make the following entry: "Postal Order for Prisoner of War."

5. The money for the order, and the receipt and other documents relating to it shall be entrusted to the intendant of the establishment for the interning of prisoners of war without being subject to the procedure of power of attorney (procuration).

6. The intendant of the establishment may address all requests concerning postal orders at the postal bureau in the name of the prisoner of war without being subject to the procedure of power of attorney.

Article I4 of the Hague "Regulations Respecting the Laws and Customs of War and Land" had provided for a Bureau of Information for prisoners of war in the following terms : ${ }^{23}$

"A Bureau of Information relative to prisoners of war shall

$=$ Op. cit., p. 500 .

${ }^{23}$ Holls, Peace Conference, pp. 148 and $43 \mathrm{I}$. 
be instituted, on the commencement of hostilities, in each of the belligerent states and, when necessary, in the neutral countries on whose territory belligerents have been received. This Bureau is intended to answer all inquiries about prisoners of war, and shall be furnished, by the various services concerned, with all the necessary information to enable it to keep an individual return for each prisoner of war. It shall be kept informed of internments and changes, as well as of admissions into hospitals, and deaths.

"It shall also be the duty of the Bureau of Information to receive and collect all objects of personal use, valuables, letters, etc., found on the battlefields or left by prisoners who have died in hospital or ambulance, and to transmit them to those interested."24

In conformity with these provisions of the Hague Convention, the following Imperial Ordinance, which has a very special interest, was issued by the Japanese Government on February 2 I, $1904:^{23}$

Article I. The Bureau of Information relative to prisoners of war will be established at Tokio and is to deal with the following matters :

(I) examination of interments, changes, admissions into hospitals, deaths, and the recording of individuals driven in as prisoners ;

(2) correspondence relating to the condition of prisoners;

(3) the receipt of gifts made to prisoners and of articles and money sent by them;

(4) preservation of wills and articles left by deceased prisoners, and the return of these articles to their families or to other interested parties;

(5) the receipt of information regarding the enemy's dead

"Art. 16 also gives the Bureaus of Information the privilege of free postage. See above.

${ }^{23}$ Nagaoka, op. cit., pp. 501-502. 
gathered upon the battlefield, and of their wills and articles found upon them, by the land or naval forces, in accordance with the regulations applied to prisoners of war.

ART. 2. The Bureau of Information shall be composed of a President and two Commissioners.

The President shall be selected from among the generals or colonels of the land army; the commissioners from among the superior or subaltern officers of the land or naval forces or from civil functionaries of the rank of "sonin."

Seven Secretaries of the rank of "hannin" are to be added to this Bureau. The number of commissioners and secretaries may be increased if deemed necessary.

Art. 3. The President shall manage the business of the Bureau under the orders of the Minister of War.

ART. 4. The President may request of the military or naval authorities and from the hospitals or ambulances all necessary communications upon the business of the Bureau.

ART. 5. The Commissioners shall administer affairs under the orders of the President.

ART. 6. The Secretaries shall work under the direction of the aforesaid superior functionaries.

Soon after this Bureau of Information was established "orders were issued to all military and naval commanders to report to the Bureau with the least possible delay, and by telegraph whenever practicable, the names of all captured Russian soldiers, their rank, and the military unit to which they were attached. In the case of the wounded the same details and information regarding the men's condition, according to the reports of the surgeons, were to be sent, and before the dead were buried every effort was to be made to ascertain their names and rank, and, failing that, an exact description was to be sent of such bodily characteristics as might serve as a means of identification. Before burial the bodies were to be carefully searched, all valuables, papers, 
and other belongings were to be catalogued, made a matter of record, and forwarded to the Bureau at Tokio, with such other information as might serve to facilitate their return to the relatives of the dead.":26

The humane spirit displayed by the Japanese in their treatment of the dead, as also their regard for sanitation, is shown by the following "Regulations Relative to the Clearing of the Battle-Field and the Interment of the Bodies upon said Field," published by the Japanese Minister of War on May 30 , 1904: ${ }^{27}$

Article I. Each army corps shall, as soon as possible, organize a body of men for clearing (corps de déblaiement) the battlefield after each battle for the purpose of searching for the sick, the wounded, and the dead, and to take necessary measures concerning the articles left by them.

ArT. 2. The sick and wounded ${ }^{28}$ shall be treated in accordance with the provisions of the "Regulations upon the Sanitary Service in Time of War." The bodies of the dead shall be treated with respect according to their position or rank, whether they belong to the imperial army or to the army of the enemy.

ART. 3. The most thorough investigation possible should be made in respect to the names, position, and rank of the men, as also in respect to the name of the company to which they belong, etc. This should be done by examining the army records, the marks of the uniform, the signs of identity, etc.

ART. 4. In general, the bodies of those belonging to the im-

${ }^{20}$ See N. Y. Times for July 25, 1904.

"For these Regulations, see Nagaoka, Revue Générale de Droit Int. Pub., pp. 611-12.

${ }^{23}$ On the treatment of the sick and wounded, see the letter of the Japanese Minister of the Navy to the President of the Red Cross Society, printed in the Revue Générale de Droit Int. Pub. for 1905, pp. 609 ff. Every one knows that the Japanese have set the world an example in sanitation and medical science as applied to the sick and wounded, and that their physicians and surgeons do not distinguish between friend and enemy either in the hospital or on the battlefield. 
perial army should be burned, whereas those belonging to the army of the enemy should be buried; but, in case there should be any fear of spreading contagious diseases, the bodies of the enemy may also be burned.

ART. 5. There shall be no burial until after it is certain that life is extinct.

ART. 6. The corps for clearing the battlefield shall gather together the bodies in one or several places, being careful to separate those belonging to the imperial army from those of the enemy. The bodies shall then be covered with straw matting or some other material. In case they should not be able to group the bodies, every effort should nevertheless be made to cover them.

ART. 7. After having observed the preceding article, the bodies should then be burned or buried as soon as possible in accordance with the distinction indicated in Article 4 .

ART. 8. The place of burning must be selected in conformity with rules Nos. I and 2, indicated below, and the place of burial in accordance with rules Nos. I, 2, and 3, indicated below: I. The place of burning or burial shall be distant from highways, towns, villages, and military posts. 2. The place of burning or burial shall be distant from the sources of water supply, from running streams, and wells or springs of which the water is drinkable. 3. For the place of burial dry and poor lands on a plateau or declivity shall be selected.

ARTS. 9 to II. (Omitted as without importance.)

ArT. I2. As far as possible the following rules should be observed in burning the bodies of those belonging to the army of the enemy: I. The bodies of officers and civil functionaries of similar rank shall be buried separately. 2. The bodies of noncommissioned officers, soldiers, and others shall be buried separately or together without ever exceeding fifty in a grave. 3. The graves should be as deep as possible and the bodies should be interred at more than a metre below the surface of the earth. 4. In the bottom of the graves branches of trees or straw shall be placed upon which the bodies shall lie; and upon the bodies shall be put a bed of lime, charcoal, cinders or min- 
eral solutions. Every precaution should be taken to guarantee proper hygienic conditions. 5. A small mound of earth taken from the grave shall be raised to mark the site.

ARTS. I3 and I4. (Omitted as of no importance.)

ART. I5. Separate mounds should be erected for the bodies of those belonging to the imperial army of Japan and for those of the enemy. Suitable marks should be placed upon each mound in order to perpetuate the memory of the dead.

ART. I6. In all cases where the bodies are buried, a suitable ceremony should be performed in accordance with the position and rank of the dead. At this ceremony Shinto or Buddhist priests, pastors, or other clergy should be asked to assist, if any such are to be found in the army where the burial takes place.

ART. 17. The bodies of the native inhabitants found upon the battlefield shall be buried in the same manner as the bodies belonging to the enemy. But when those having the right to do so shall ask for the delivery of such bodies, as much as possible must be done to grant the request.

ART. 18. (Omitted as of no importance.)

ART. 19. As for those belonging to the army of the enemy of whom the names, age, nationality, position, rank and company are known, a list of their names together with the place of discovery of the body and of its burial, as also the dates of such discovery and burial, should be drawn up. This list shall be transmitted to the Bureau of Information for prisoners of war by the commander of the place who shall at the same time send to the same Bureau the belongings left by the dead. These should be made into parcels upon each of which shall be inscribed the name, rank, etc., of its owner. But the provisions above mentioned are not applicable to arms, horses, and military documents.

ART. 20. The belongings left by the dead native inhabitants upon the battlefield shall be delivered to the nearest local authority by the commander of the company of the place for the purpose of restoring them to those having the right to claim such articles. 
ART. 2I. The commander or the company of the place shall take such measures as may be necessary, according to circumstances, in respect to arms, provisions, horses, and military documents as well as belongings left by unknown owners. The articles enumerated in the preceding paragraph will be considered as booty, excepting those belonging to the imperial army (of Japan).

ArTs. 22 to 24. (Omitted as without importance.)

With certain omissions on the part of Russia which have been noted, the Russian as well as the Japanese Instructions certainly breathe a spirit of the highest type of humanity and religious tolerance. ${ }^{28}$ They are worthy of all praise and imitation. The usages which they enjoin are now indeed so generally observed in civilized warfare that they may be said to constitute at least a part of the spirit of the law of nations.

20 This is particularly true of the Japanese Instructions of February 10 and 19,1904 . 


\section{CHAPTER XI}

\section{The Relations of the Belligerents with Each OTHER}

The relations of the belligerents with each other during the Russo-Japanese War derive especial importance from the fact that both belligerents were signatories to the Hague Convention of 1899 , which adopted an international code of laws and customs for the regulation of land warfare, and also from the fact that this war witnessed the first attempt to put into practice some of the provisions of this code. ${ }^{1}$

In respect to the treatment of subjects or citizens of the enemy state found within belligerent territory at the outbreak of the war and of the number of "days of grace" allowed to enemy merchantmen lying in belligerent ports, the conduct of Japan, as well as that of Russia, although not, strictly speaking, illegal, left much to be desired on the score of liberality. The Japanese Imperial Decree of February 9, I904, permitted Russian merchantmen, ${ }^{2}$ provided

"This code, which was essentially based upon that drawn up by the Brussels Conference in 1874 , was largely ignored during the Boer War, perhaps partly because the Boers were not a party to the Hague Conference. While the conduct of the Boers was, under the circumstances, worthy of much praise, the English fell short in some respects, not merely of the Hague Regulations, but of the standards set by modern civilization, especially in the matter of the treatment of prisoners of war and of non-combatants. For plenty of evidence of the truth of this assertion, the reader is referred to Despagnet, La Guerre Sud-Africaine, and Desjardins in Revue des Deux Mondes, Mars, 1900, pp. $38 \mathrm{ff}$, passim.

'See supra, p. 28I. It will be seen that the Japanese ordinance also provided that Russian merchantmen which had left foreign ports for Japan before February 16 might enter Japancse ports on certain conditions. 
they did not have contraband of war on board, to load and discharge their cargoes and remain in Japanese ports until February 16 (i.e., for a period of seven days) ; and, according to the second article of the Czar's Order of February $28,{ }^{3}$ Japanese ships of commerce (having no contraband of war on board) found in Russian ports at the time of the declaration of war (February Io) were in no case to be allowed to remain more than forty-eight hours after the publication of the "present declaration" by the local authorities.

Although all enemy vessels are, strictly speaking, liable to capture immediately after the outbreak of war, recent practice has been much more liberal and indulgent than was the attitude of Russia and Japan toward each other at the outbreak of the Russo-Japanese War. At the beginning of the Crimean War six weeks were allowed by Russia, England and France," and "concessions of a like kind were made to each other by France and Prussia in 1870, and by Russia and Turkey in 1877."' According to the Proclamation issued by President McKinley on April 26, I898, soon after the outbreak of the Spanish-American War, Spanish merchant vessels in American ports were to be allowed until May 2I, I898, inclusive, for loading their cargoes and departing from such ports. They were not to be captured on their return voyage unless their cargoes included contraband of war, Spanish military or naval officers, or any dispatches to or from the Spanish Government. It was further pro-

- See supra, p. 269. It will be seen that the Japanese ordinance also provided that Russian merchantmen which had left foreign ports for Japan before February 16, 1904, should be permitted to enter Japanese ports on certain conditions.

- See Dana's Wheaton, note 156, p. 389.

'Lawrence, Principles, p. 384. 
vided that "any Spanish merchant vessel which, prior to April 2r, I898, shall have sailed from any foreign port bound for any port or place in the United States, shall be permitted to enter such port or place, and to discharge her cargo, and afterward fortwith to depart without molestation." Such a vessel, it was declared, was not to be captured on her return voyage. ${ }^{6}$.

It is also to be noted that, although the Russian Government declared that "Japanese subjects are authorized to continue, under the protection of the Russian law, to reside and follow their peaceful callings in the Russian Empire," the "territories forming part of the Imperial Lieutenancy in the Far East" (where the great majority of Japanese to be found in the Russian Empire must have resided) were expressly exempted from the terms of this declaration. The Japanese Government in its Instructions of February ro, $1904,{ }^{8}$ made no exceptions whatever, although it was made clear that such permission must be regarded as a pure act of grace and as conditional upon good behavior.

The Japanese complained bitterly during the early stages

- For the text of the Proclamation, see House Doc. of 55th Congress, 3d session (For. Rel. I898), p. 772. Cf. Stockton's Naval War Code, Art. 15, for an official statement of the rules governing American practice.

These liberal rules have been given a still wider interpretation at the hands of the American judiciary. In the case of the Buena Ventura ( 1899,175 U. S. 384) the United States Supreme Court held that the enemy's vessels were included within the intention of the President's Proclamation, even though their departure from an American port took place before the war had begun. The Buena Ventura, which had left Ship Island, Mississippi, on April 19, two days before the outbreak of hostilities, and which was captured on April 22, a day after this outbreak, was accordingly released. On "Days of Grace," see especially Lawrence, War and Neutrality, ch. 3.

'See Art. 17 of the Russian Imperial Ordinance, given above, p. 269.

See supra, pp. 28I-282. 
of the war of the hardships suffered by their compatriots in Manchuria and Siberia in consequence of their sudden and cruel expulsion from these territories. Japanese refugees at Niu-Chwang and Port Arthur appear to have been robbed and cruelly maltreated (in some cases they were even murdered) ; and the Russian soldiery and police, instead of preventing these outrages, are even said to have participated in them. ${ }^{\circ}$

On March 19, 1904, Mr. Takahira, the Japanese Minister at Washington, requested the good offices of the American Embassy at St. Petersburg (which had assumed charge of Japanese interests in Russia) in behalf of about fifty destitute Japanese subjects in Tsitu (Chita?), Siberia. It appears that among these unfortunates were nineteen Japanese who had been suddenly ordered by the police authorities to leave Irkutsk without a moment's warning and who were thus unable to take with them any of their effects. Our State Department and the American ambassador in St. Petersburg acted with great promptness, and some at least of these objects of mistreatment on the part of Russian authorities reached Berlin in safety, where they were cared for by the Japanese Legation. ${ }^{10}$

Although, as a matter of strict law, a belligerent still has an unquestionable right to expel enemy subjects from its territory, this right should undoubtedly only be exercised in

- See especially a Reuter's dispatch from Niu-Chwang, dated February 16, and a dispatch from its special correspondent at Nagasaki, dated March 3, 1904, in the London Times.

${ }^{10}$ See House Doc. of 58th Congress, 3 d session (For. Rel. 1904), pp. 431-32 and 715. See also N. Y. Times and Washington Post for March 20, 1904. About 800 Japanese residing in Russia were subsequently transported from Russia to Germany through the kind offices of our ambassador at St. Petersburg. See House Doc., op. cit., p. 436. 
extreme cases and under very exceptional circumstances. Modern practice permits the citizens or subjects of enemy states to remain in belligerent territory unless their expulsion is demanded by considerations of military necessity. ${ }^{11}$

It is always difficult to obtain full and unbiased information concerning the actual conduct of belligerents in any war. This was especially true during the Russo-Japanese War owing to the remoteness of the field of military operations and the rigor of the censorship on both sides. The Japanese were particularly secretive and their success in concealing from the world all knowledge of their military and naval movements was one of the marvels of modern warfare. Consequently, we are not in a position to present the reader with a very complete account of the relations of the belligerents with each other during the war. Certain incidents occurred, however, and certain revelations were made which throw considerable light upon this interesting subject.

There was much unfavorable criticism of Russian methods of warfare by the Japanese and by pro-Japanese critics in consequence of the sinking of several Japanese trading vessels and transports during the early period of the war. Among these were the Nakonoura Maru on February II,

"Soon after the outbreak of the Boer War (1899), a sentence of expulsion was pronounced upon all Englishmen residing in the Transvaal and the Orange Free State. In 1870 , the French Government ordered all Germans to leave the Department of the Seine, but this extreme measure appears to have been taken primarily in the interest of the Germans themselves.

On the general subject of the effect of war on resident enemies, see especially Lawrence, Principles, pp. 328-330; Hall, 126 and notes; Twiss, II, \$ 46-5I; Taylor, \& 463; Rivier, II, pp. 229-23I; Bonfils, 88 1052-56; Calvo, IV, 1912-15; Geffeken's Heffter, 88121 and 126; and De Martens, III, pp. 197-200. 
the Goyo Maru and the Kinshiu Maru on April 25 and 26, and the Hitachi Maru on June 15, 1904. All of these vessels were either fired upon and sunk, or captured and sunk, without being sent to a Russian Prize Court for adjudication.

The Nakonoura Maru was captured and sunk and her crew was "taken on board a Russian man-of-war and conveyed to Vladivostok, from whence they were sent back to Japan by a German steamer." ${ }^{2}$ The sinking of this vessel may be justified on the ground of military necessity, ${ }^{13}$ for the weather is said to have been "terrific" and the ship was so greatly damaged as to be unseaworthy. "The same considerations apply to the case of the trading steamer Goyo Maru, except that the reason for not sending her in for adjudication by a Prize Court was the close proximity of a superior Japanese squadron." 14

Some of the Japanese troops on board the transport Kinshiu Maru surrendered, and these were held as prisoners of war; but several hundred of them preferred to go down with the ship. If our information be correct, the same thing seems to have happened in the case of the transport Hitachi Maru. Some of the Japanese troops on board surrendered, but the rest refused quarter and went down firing on the

${ }^{12}$ Lawrence, War and Neutrality, p. 41. The first accounts in the newspapers represented that the vessel had been suddenly fired upon without warning or summons to surrender, and that all on board were either killed or drowned, but later information showed that this was an error. This would, as Lawrence (op. cit., p. 40) observes, have been a "gross outrage."

${ }^{23}$ As we have seen in a previous chapter, a broad line of distinction should be drawn between neutral and enemy ships in this respect. See supra, p. 156 and $\mathrm{n}$.

${ }^{24}$ Lawrence, op. cit., pp. $4^{1-42}$. 
Russians as they sank. ${ }^{15}$ This was doubtless brave and gallant conduct from the Japanese point of view, and even we of the West can not withhold our admiration; but, however splendid, it was not war, and the Russians should not be censured either for sinking these transports or for refusing to treat as non-combatants those who had not surrendered and some of whom, at least, continued fighting. ${ }^{16}$

The conduct of both belligerents in the war appears, on the whole, to have been distinclty honorable in abstaining from the use of ruses or methods implying treachery. Among the prohibitions of the Hague Convention ${ }^{17}$ and of International Law are "the improper use of a flag of truce, the national flag, or military ensigns, and the enemy's uniform as well as the distinctive badges of the Geneva Convention," although "ruses of war and the employment of methods to obtain information about the enemy and the country are considered allowable."

An Associated Press Dispatch from St. Petersburg, dated

${ }^{15}$ Nearly all the officers of the Hitachi Maru as well as the Kinshin Maru are said to have performed harakiri.

${ }^{18}$ This conduct on the part of the Russians was, however, contrasted with the humane conduct of the Japanese Vice-Admiral Kamimura, who, in August, 1904, gave up the pursuit of the Russian cruisers Gromoboi and Rossia in order to save the lives of 600 Russians struggling in the sea, who had cast themselves in the water when their vessel, the Rurik, began to sink. See Chicago Tribune and N. Y. Times for August 16, I904.

${ }^{17}$ Arts. $23 \mathrm{f}$ and 24 of the Hague Regulations. These prohibitions, which are also those of the Brussels Conference (see Art. 13f), have been frequently violated even in recent wars. During the Boer War, the Boers brought several serious accusations against the British for firing upon or abusing the distinctive signs of the Geneva Convention and firing upon a Red Cross ambulance. The English, in their turn, charged the Boers with no less than six violations of the rights of a bearer of a flag of truce. See Desjardins in Revue des Deux Mondes, Mars-Avril, 1900, pp. 49-50, and Despagnet, La Guerre Sud-Africaine, passim. 
May 10, $1904,^{18}$ stated that Russia had protested to the Powers signatory to the Hague and Geneva Conventions against the action of the Japanese in firing on the Red Cross train coming from Port Arthur on May 6. Out of two hundred sick and wounded on this train, two were said to have been struck by Japanese bullets. On May I 2 the Japanese Legation at London published an official telegram from the Foreign office at Tokio in explanation of this apparent violation of the law of nations. It asserted that the train carried no distintive marks and that the Japanese merely responded to firing from Russian soldiers on board. When the train stopped and a Red Cross flag was hoisted, the Japanese immediately ceased firing. ${ }^{19}$ It appears that the train was a composite one, partly devoted to the use of the Red Cross service and partly filled with Russian soldiers and non-combatants who had seized this opportunity of leaving Port Arthur. "If," as Lawrence observes, ${ }^{20}$ "this account be correct, not only was the Japanese force fully justified in firing, but Japan might have preferred a counter-charge against the Russians of an unlawful use of the Red Cross to cover the escape of soldiers and high officials. . ..$^{21}$ The Geneva Convention is quite clear upon the point that immunities accorded to the Red Cross badge are conditional upon its exclusive use to cover persons and things connected with the care of the sick and wounded. The Japanese troops would have been well within their rights if they had captured the train and all that it contained."

${ }^{28}$ See Chicago Record-Herald for May II, 1904.

10 Ibid., May 13, 1904.

${ }^{20}$ War and Neutrality, pp. 43-44.

${ }^{21}$ It was reported that Admiral Alexieff was on board this "Red Cross" train. 
Several other charges of treachery in the use of the white flag, the Red Cross flag, and the national flag were made during the war, although we are not in a position to pronounce upon their truth or falsity. An Associated Press Dispatch from Tokio, dated June $16,1904,{ }^{22}$ stated that it was reported in official dispatches from Japanese officers in the field that a body of Russian soldiers had induced the Japanese artillery to cease firing upon them by the use of the Japanese flag at the battle of Telissu. At the battle of Yentai in October, I904, the Japanese were accused of endeavoring to protect themselves from a heavy Russian fire by the use of the Red Cross flag. ${ }^{23}$ In an interview ${ }^{24}$ with a correspondent of the Associated Press at Che-Foo in September, 1904, Lieut. Prince Radziwill, a Polish officer in the Russian army, declared that both besiegers and besieged at Port Arthur had developed such strong feelings of mutual hatred and suspicion that even "flags of truce for the burial of the dead were ignored by both sides." The result was that great numbers of Japanese dead remained unburied and the stench in Port Arthur from their decomposing bodies was almost unendurable. Our informant also related the following incident: In the course of the assaults on Port Arthur, which took place during the last four days of August, 1904, two companies of Japanese soldiers, finding themselves at the mercy of the Russians, hoisted the white flag. But to this the Russians paid no attention and they continued to fire volley after volley upon the helpless enemy. In the meantime, the Japanese troops in the rear of these two companies expressed their disapproval of this attempt

\footnotetext{
2 See Chicago Record-Herald for June 17, 1904.

${ }^{23}$ Chicago Tribune for October ${ }_{15}$, 1904.

${ }^{24}$ See $\epsilon$. g., N. Y. Times and Chicago Tribune for September 19, 1904.
} 
on the part of their comrades to surrender by also firing upon them. As a result of this double fire from friend and foe 600 Japanese soldiers are said to have been killed. ${ }^{25}$

Although a general is under no obligation to receive the bearer of a flag of truce under all circumstances, ${ }^{26}$ and although it is not required that firing shall immediately cease upon the appearance of a flag of truce in battle, ${ }^{27}$ it was customary even in ancient times to grant truces for the burial or disposal of the dead. It is to be hoped that modern belligerents will not permit themselves to fall short of the standard set by the ancients in this respect, and that such scenes as Port Arthur witnessed during the recent struggle may never be repeated. To grant burial to the dead is "a sacred duty toward the individual and toward humanity in general." 28

The Japanese were repeatedly accused of disregarding the

${ }^{25}$ Instances of the abuse of the Japanese and white flags by the Russians are also related by J. H. de Forest in The Independent for October 5, 1905 .

${ }^{23}$ Art. 33 of the Hague Regulations.

${ }^{27} \mathrm{Cf}$. Arts. 112 of the American Instructions and 40 of the Russian Instructions, cited above.

${ }^{28}$ Guelle, Précis des lois de la guerre, I, p. 185. Guelle cites with approval the following rule formulated by G. F. de Martens, Précis, \$ 285 ; "It is contrary to the laws of war to deprive the dead of burial. The victor in a battle should take care of the dead and wounded. When the result of the battle is indecisive, suspensions of arms of one or two days during which each side may withdraw his own (dead or wounded) are sometimes granted."

During the Spanish-American War of 1898 , the Spaniards, when too weak or few in number to dig the ditches necessary for the burial of the dead, sometimes gathered the bodies together into heaps and burned them in order to prevent the spread of infectious diseases. BonfilsFauchille, \& I 108. For sanitary and climatic reasons, the Japanese were also forced to burn the bodies of the Chinese dead in Manchuria during the Chino-Japanese War in $1894-5$, in spite of the aversion of the Chinese for cremation. Ariga, La Guerre Sino-Japonaise, ch. 8. 
obligations of the Hague and Geneva Conventions ${ }^{29}$ by bombarding Red Cross hospitals, quarantine stations and hospital ships during the siege of Port Arthur. In November, 1904, General Balashoff, the head of the Red Cross Society at Port Arthur, sent a personal letter to the Associated Press $^{30}$ charging the Japanese with a violation of the rules of civilized warfare. He claimed that the Japanese fire had "compelled the abandonment by the Russians of three plainly marked hospital ships, and that the wounded who were aboard the half-sunken steamer Andara also had to be removed." "These ships," said General Balashoff, "were anchored where they did not interfere with the Japanese fire against the Russian warships." He further stated that "the Japanese, who use balloons to direct their fire and who drop their shells with accuracy into the harbor, can not mistake the hospital ships," and he charged that they deliberately drove the wounded from the ships for the purpose of sinking the vessels. "This occurred recently," continued General Balashoff, "but earlier I noticed several instances of a concentration of fire on portions of the city devoted almost exclusively to hospitals. Other instances of uncivilized warfare are numerous, but I have no time to write them." In December, 1904, General Nogi replied as follows ${ }^{31}$ to General Stoessel, who had complained of the bombardment of Red Cross hospitals at Port Arthur:

"I have the honor to assure you that the Japanese army, re-

20 See Art. 27 of the Hague Regulations and Art. I of the Geneva Convention of 1864 . On the inviolability of hospital ships, see Arts. I-8 of the Third Convention adopted by the Hague Conference, Holls, pp. 123-131 and 463-473. The additional Articles of the Geneva Convention of 1868 have never secured the formal sanction of the Powers.

${ }^{20}$ N. Y. Times for November $21,1904$.

${ }^{31}$ See N. Y. Independent for December 22, 1904. 
specting humanity and treaties since the beginning of the siege, has never purposely directed shells against buildings or vessels flying the Red Cross, but the greater part of the garrison is invisible from our gun positions, and as you know shells do not always reach the place to which they are directed, and especially owing to your long and brave resistance the deviation of our guns is becoming greater and greater. So with the greatest regret we are unable to guarantee them to reach the places at which they are directed." 32

In the latter part of March, 1905, the French Government, which was intrusted with the protection of Russian interests in Japan during the war, is said to have transmitted to Tokio a Russian protest against an alleged infraction of the laws of war on the part of Japan. It was charged that during the attack on Port Arthur, on March Io, the Japanese had fired over fifty projectiles at the quarantine station on the island of San-Shan-Top, resulting in the injury of numerous persons. $^{33}$ To this protest Baron Komura, the Japanese Minister of Foreign Affairs, is said to have replied that the Japanese Government had received no report from Vice-Admiral Togo concerning the destruction of the quarantine station; but, whether the station had been destroyed or not, the article of the Hague Convention quoted by Russia in support of her protest related only to land warfare, the Convention having left the question of naval bombardment unsettled. ${ }^{34}$

${ }^{82}$ The Peking correspondent of the London Times (see weekly ed. for January 27, 1905) bore witness to the humanity of the Japanese at Port Arthur in directing their fire on the docks, workshops, and warships in the harbor rather than on the buildings marked with the Red Cross, although there were many such in an exposed position. He declared that out of three hospital ships in the harbor, but one was struck, and that by a single shot.

${ }^{82}$ N. Y. Times for March $21,1905$.

"Ibid., March 31, 1905. This argument of Baron Komura's is tech- 
In October, I904, the Japanese Minister at Washington is said to have requested the American State Department to transmit to Russia a protest $^{35}$ against the use of Chinese clothing by bodies of Russian troops in violation of the Hague Convention. It was explained in St. Petersburg that, owing to the sudden descent of winter, some of the Russian troops in Manchuria were permitted to purchase the warm outer garments or Chinese overcoats worn by the native population. It was also stated that the use of these garments was to be merely temporary, and that every effort had been made to alter them in such a manner as to prevent any possibility of mistaking their wearers for Chinamen. If the facts were as stated, the Russian Commander who authorized these purchases appears to have been well within the requirements of the Hague Convention, which merely requires the militia and volunteer corps as well as the regu-

nically correct. The Hague Regulations, including Article 27, apply only to land warfare. This article runs as follows: "In sieges and bombardments all necessary steps should be taken to spare as far as possible edifices devoted to religion, art, science, and charity, hospitals, and places where the sick and wounded are collected, provided they are not used at the same time for military purposes. The besieged should indicate these buildings or places by some particular and visible signs, of which the assailants should previously be notified." It is also true that the Hague Convention left the question of naval bombardment unsettled, but it appears that both Count Lamsdorff and Baron Komura erred in confusing Arts. 25 and 27 of the Hague Regulations. Article 25 simply forbids the bombardment of undefended towns, villages, habitations and buildings. From the standpoint of humanity and International Law, there is no more reason for a violation of the principles embodied in Articles 25 and 27 by a naval than by a land force.

${ }^{33}$ See London Times (weekly) for October 21 and 28, 1904. See also Chicago Tribune for October 2I, 1904. The correspondence relating to this protest is not found in the Forcign Relations of the United States for 1904 . 
lars "to have a fixed distinctive emblem recognizable at a distance." 38

The conduct of both belligerents, especially of the Japanese, appears also to have been comparatively free from acts of cruelty and barbarity. The Cossacks were accused by the natives of plundering and burning villages and farm-houses, and even of outrages on women in northeastern Korea, ${ }^{37}$ and vague but sensational charges of mutilation of the dead and of the wounded were made against the Japanese by the Russians early in July, I904. ${ }^{38}$ These charges were met by a denial and counter-charges against the Russians on the part of the Japanese, who cited a number of specific instances, giving names, dates and places. ${ }^{30}$ Although the

Art. I. The memorandum issued by the Japanese Foreign Office is said to have contained a statement to the effect that this use of Chinese clothing was "contrary to Art. 23 of the supplementary rules to the Convention of Laws and Customs of War." This is manifestly an error.

${ }^{87}$ London Times (weekly) for July I, 1904. This same correspondent bears witness to the excellent conduct of the Russians as well as of the Japanese in the district around Feng-Hwang-Chem in southern Manchuria.

${ }^{83}$ On the Russian charges against the Japanese, see the N. Y. Times for July I and 3, 1904. These charges, which are said to have been originally based on the sensational declarations of a Russian novelist and war correspondent, were officially denied by the Japanese Government. This denial was generally accepted throughout Europe and America. The charges were too vague and general in their character to be trustworthy.

${ }^{30}$ Thus the Chief of Staff of the second Japanese army reported that "on the I5th of June a petty officer and other soldiers, six in all, belonging to the Eighteenth Infantry regiment, encountered, while scouting, about fifteen Russian troops at Chengtsushan, and were killed after hand to hand fighting. On the death of these men the Russians thrust their bayonets into their mouths and cut open their lungs, and took away the contents of their pockets.

"On the 27th of June Kobayashi Wachihi, a first-class cavalryman belonging to the Third Cavalry regiment, who was scouting at a point about four kilometers (three miles) northeast of Heunyocheng, was at- 
Japanese charges on this head were much more direct, specific and authoritative than were those of the Russians, it is not to be believed that even the Russians were guilty of outrages or atrocities of this nature on a large scale. These were doubtless isolated cases such as come to light in nearly every war, for that breed of degenerates known as hyenas of the battle-ficld is not yet extinct.

Another source of complaint on the part of the Japanese was the enlistment in the Russian military service of criminal convicts from the island of Sakhalin. On May I9, 1904, Admiral Alexieff issued a general order ${ }^{40}$ offering special inducements to these convicts, including some of the most dangerous criminals ${ }^{41}$ in the Russian Empire, for joining the Russian standards. Two months of active service were to count as a year of penal servitude, and "colonists" -i.e., prisoners who are permitted to live outside the prisons during a portion of the time-were to have a certain part of their sentences remitted.

tacked by the Russians and fell dead on the ground. Thereupon about twenty Russian cavalrymen surrounded the dead man and barbarously stabbed his dead body several times. At this moment a company of our cavalry approached the scene and the Russians fled, leaving the body of the man to our hands." From the Chicago Tribune for July 4, 1904. $C f$. the account in the London Times (weekly) for July 8, 1904.

On July 15 (see N. Y. Times for July 18, 1904) the War Office at Tokio published a statement from General Oku's army specifying eleven instances of Russian misconduct in the field. Two instances were given of abuse of the white flag; one of persistently firing on a field hospital conspicuously flying the Red Cross flag; two of firing on men of the Hospital corps who wore Red Cross badges; three of stabbing, shooting and slashing the wounded; two of shockingly mutilating the dead; and one of stealing cattle and horses and assaulting women.

${ }^{\star 1}$ For the terms of this order, see London Times (weekly) for May 27, and N. Y. Times for August 17, 1904.

${ }^{47}$ Out of a total of 22,167 convicts on the island, at least 8,000 are said to have been charged with murder. 
Although it is nowhere expressly stated that the enlistment of convicts is a violation of the law of nations, it is generally agreed that "International Law forbids civilized nations to enroll in their armies savages to whom the laws of war are unknown, or to employ as auxiliaries troops which neither know nor respect the laws and customs of civilized peoples." 42 But this prohibition does not apply to indigenous or native races organized into regular troops of a civilized state, drilled and commanded by its regular officers, and obeying the rules and customs of civilized warfare. ${ }^{43}$ Whether Russia committed a violation of the law of nations in permitting the enlistment of these convicts would seem to depend upon their amenability to discipline and control, and upon the question whether proper means were taken to insure the observance of the rules and usages of civilized warfare by these convicts. In any case, however, there is some-

'This is the identical language of Bluntschli, \&59, and Calvo, \& 2056. See also Woolsey, \& I33, p. 213; Heffter, \& 125, p. 281; Bonfils (Fauchille), § ro70.

${ }^{43}$ See especially Woolsey, p. 213; Lawrence, Principles, pp. 424-26; Despagnet, La Guerre Sud-Africaine, p. 121. The latter author describes at length the charges against the English for violations of this rule during the South African War. During the Spanish-American War the Spanish Government protested against the conduct of the United States in furnishing arms and ammunition to the insurgent Cubans and Filipinos. See Le Fur in Revue Générale de Droit International Public, t. V, pp. $753 \mathrm{ff}$. But Le Fur, who charitably suggests that the Americans should not be blamed too much in view of the tropical climate in these islands, himself admits that the Spanish sometimes contradicted themselves by speaking of these people as "savage" at one time and "civilized" at another. Whatever violations of the laws and customs of war the Cubans and Tagals may have committed, the Americans were not responsible; for these peoples had revolted from Spain, and the Americans simply went to their assistance.

The French have been severely criticized for employing the African and Mohammedan Turcos against the Germans in 1870, but these formed part of the regular French army. 
thing peculiarly revolting to modern conceptions of humanity in the employment of criminals for purposes of warfare.

Each of the belligerents in the war was accused of an attack upon an undefended coast town without giving previous notice to the authorities. In the earlier days of the war (on March 6, I904) a Japanese fleet suddenly appeared off the coast of Vladivostok and bombarded the inhabited and undefended part of the city as well as the forts and shore batteries. ${ }^{44}$ On June 20, 1904, a fleet of six torpedo boats belonging to the Russian Vladivostok squadron entered the Japanese harbor of Gensan and, in addition to burning two Japanese merchant vessels which they found there, they are said to have fired about two hundred shots into the town. ${ }^{45}$ Fortunately no serious damage appears to have been done in either case.

Article 25 of the Hague Regulations asserts that "the attack or bombardment of towns, villages, habitations, or buildings which are not defended, is prohibited;" and Art. 26 declares that "the Commander of an attacking force, before commencing a bombardment, except in the case of an assault, should do all he can to warn the authorities." But these prohibitions, like all of those included in the annex to the Second Convention of the Hague Conference, are intended as a code for the regulation of warfare on land, and do not, therefore, strictly speaking, apply to naval warfare. ${ }^{48}$

" See report of Admiral Alexieff in London Times (weekly) for March 1I, 1904. The bombardment lasted for nearly an hour, but the injury was very slight, only one person (a woman, and hence a noncombatant) having been killed.

${ }^{13}$ London Times (weekly) for July 8 and I5, I904.

* It was proposed at the Hague Conference to extend the interdiction of Article 25 to bombardment by a naval force as well as to those on land; but, because of opposition on the part of Great Britain to such a declaration, action was limited to the expression of a "wish" that this 
The preamble to the Second Convention of the Hague Conference declares, however, that "in cases not included in the Regulations, populations and belligerents remain under the protection and empire of the principles of International Law, as they result from the usages established between civilized nations, from the laws of humanity, and the requirements of the public conscience. ${ }^{47}$

Recent publicists are divided in their opinions as to whether the bombardment of an undefended commercial port or sea-coast town is, as a rule, permissible, but the majority of them appear to maintain, either that the same rules should apply in naval as in land warfare, or that the exercise of the right, if it exists, should be resorted to only in exceptional cases, $e$. g., by way of reprisal or on the ground of military necessity. It is also generally held that, at least whenever compatible with the military interests of the attacking party, previous notice of intention to bombard should always be given to the authorities or inhabitants of the place about to be bombarded. ${ }^{48}$

proposal might be considered by a future Conference. See Holls, pp. 379 and 519; Pillet, p. 469; and De Lapradelle in Revue Générale de Droit International Public, t. VI, pp. 730-33.

${ }^{n}$ Holls, p. 419. This preamble, too, applies strictly speaking, merely to warfare on land, but the principles it announces are, we think, of universal applicability.

4s I have merely tried to register the general drift of opinion on this subject. The variety of views and general lack of harmony, which still prevail among publicists, may be seen by scanning the following citations from leading authorities:

Bonfils ( $\& 1277$ ) is of the opinion that the rule should be the same in naval as in land warfare.

Rivier (Principles, II, \& 193, pp. 283-84) thinks the bombardment of an "exclusively commercial port" justifiable only in exceptional cases, $i$. e., by way of reprisal or on grounds of military necessity, as in the 
The best recent practice on this head is probably that indicated in Article 4 of the United States Code of Naval War-

analogous case of devastation. (See op. cit., p. 265.) He considers previous notice also desirable whenever possible.

Calvo (IV, \& 2068) holds that "in no case, under no pretext, is it permissible to bombard open, unfortified or undefended towns; to act against these as the necessities authorize one to act against fortresses is to violate all the principles of the law of nations and to place oneself outside of the law of the nations which march at the head of civilization."

Perels (Manuel, p. 212) says: "Open towns and places which are undefended can not be bombarded; it is the same with open places on the seacoast." He does not consider previous notice obligatory.

Bluntschli ( $\$ 554$ bis) is of the opinion that "open towns which do not resist may be occupied, but it is interdicted to cannonade them without necessity." He does not appear to distinguish between land and naval warfare. Bluntschli ( $\$ 553$ ) admits that it is customary to give notice of intention to bombard, but he does not seem to regard such previous notice as necessary in all cases.

Pillet (Les Lois, etc., § 7I) thinks that "a fleet should not bombard an open place" and that "bombardment is only legitimate as a means of reducing a port which resists the attack of the enemy." He admits that recourse to bombardment must needs be more frequent in naval than in land warfare, since it is the only means open to a fleet of taking a town which resists; nevertheless "bombardment is only legitimate if it have a precise object: to take possession of a place or of a fleet which has sought refuge in a port." Previous notice should be given in all cases if possible.

Woolsey (pp. 223-24) says: "The bombardment of open undefended towns is now unlawful." He applies this rule to undefended sea-ports as well as to undefended places on land.

Field (Code, $\$ 756$ (4) and note 5) thinks that the "bombardment of defenceless places should be prohibited, though it has been regarded as allowable." He not only insists upon notice of intention to bombard, but upon the allowance of a reasonable time for the removal of all noncombatants $(\$ 757)$.

Walker (Manuel, p. I42) says: "It is clear law that only fortified and defended places are, at any rate in land warfare, liable to bombardment, and notice for the benefit of non-combatants is not uncommonly given previous to the bombardment of a fortified town, but no such notice is legally necessary."

Taylor $(\$ 469)$ claims that "there is no law or practice which limits bombardment from the sea to fortified places as on land," but he insists 
fare, which says: "The bombardment, by a naval force, of unfortified and undefended towns, villages, or buildings is

that "the bombardment of unfortified and undefended towns and places for the non-payment of ransom is forbidden."

Lawrence (Principles, \$ 443) thinks that "open and undefended places should not be bombarded at all; and recent proposals to extort large sums from rich and defenceless coast towns by the agency of a squadron whose guns should lay them in ruins in case of refusal, are retrograde and barbarous." Lawrence here refers to the views of the French Admiral Aube, published in 1882 in an article on the naval warfare of the future in Revue des Deux Mondes. Admiral Aube had expressed the opinion that "armoured fleets in possession of the sea will turn their powers of attack and destruction against the coast towns of the enemy, irrespectively of whether these are fortified or not, or whether they are commercial or military, and will burn them and lay them in ruins, or at the very least will hold them mercilessly to ransom," and he claimed that this would be the true policy of France in the event of a war with England. Cited by Hall, p. 431.

Hall ( $3 \mathrm{~d}$ ed., $\$ 8 \mathrm{I} 40$ and 186 ) earnestly combats these views, which appear to have found much favor in French and British naval circles; but he unfortunately lends the weight of his great authority in favor of the opinion that regular war contributions may be levied on undefended coast towns, provided a sufficient force, which actually takes temporary or permanent possession, is landed. This view, of course, implies the ultimate right of bombardment in case of a refusal to pay. For another excellent criticism of the views of Admiral Aube, see Dupuis, Le Droit de la Guerre Maritime, \$\$ 67-74.

At its Venice session, in 1896 , the Institute of International Law (see Annuaire for 1896, pp. 311-12) asserted that "there is no difference in the laws of war between the rules governing bombardment by land forces or bombardment by naval forces," and it was declared that the principles enunciated in Articles 32, 33 and 34 of the Manual of the Institute (Oxford Code) were equally applicable to naval as to land bombardments. It declared the bombardment of an open town by a naval force inadmissible, except ( 1 ) to obtain requisitions or contributions necessary for the fleet, and (2) to destroy dock-yards, military establishments, depots of war munitions, or war vessels found in a port. Bombardment for the purpose of exacting ransom or of bringing about the general submission of the country were especially denounced. Dupuis ( $o p$. cit. note on pp. $9 \mathrm{I}$ ff.) considers these rules wise, except in authorizing bombardment in case of a refusal to pay a war contribution.

Professor Holland, who drew up these rules, considers bombardment of an open town lawful in the following cases: (I) "as a punishment 
forbidden, except when such bombardment is incidental to the destruction of military or naval establishments, public depots or munitions of war, or vessels of war in port, or unless reasonable requisitions for provisions and supplies essential, at the time, to such naval vessel or vessels, are forcibly withheld, in which case due notice of bombardment shall be given. The bombardment of unfortified and undefended towns and places for the non-payment of ransom is forbidden." ${ }^{49}$ It is impossible to say whether the excellent principles embodied in this article will be followed in future wars, as very few opportunities for such bombardment have presented themselves in recent times. ${ }^{50}$

for disloyal conduct; (2) in extreme cases, as retaliation for disloyal conduct elsewhere; (3) for the purpose of quelling armed resistance (not as a punishment for resistance when quelled); (4) in case of a refusal of reasonable supplies requisitioned, or of a reasonable money contribution in lieu of supplies." It would, he conceives, be unlawful: "( 1 ) for the purpose of enforcing a fancy contribution or ransom; (2) by way of wanton injury to private property." Holland, Studies in International Law, p. 99.

For examples of famous sieges and bombardments, see Guelle, Précis. I, pp. Iog-122 Calvo, IV, \& 2067-2096; and F. de Martens, III, pp. $220 \mathrm{ff}$.

${ }^{4} \mathrm{C} f$. the resolution of the Institute of International Law cited in footnote above. In one respect Art. 4 of the United States Naval Code is an improvement upon the recommendation of the Institute. No mention is made of war contributions by way of exception. There is no good reason why a fleet should levy such contributions. As a rule, it can have no need of money to conduct its operations. See on this point Dupuis, op. cit., note on pp. 9I-92.

${ }^{\infty}$ The British had no opportunity to bombard coast towns during the Boer struggle and the United States had no occasion to do so during the Spanish-American War. The Germans were guilty of gross violations of the laws of warfare in respect to sieges and bombardments during the Franco-Prussian War, but all of the cases which have come under our observation relate to sieges and bombardments on land. F. de Martens (III, 220) characterizes the bombardment of certain open towns on the Black Sea by the Turkish fleet during the Russo-Turkish War in $1877-78$ as a "violation of the laws of war." 
If the Japanese bombardment of Vladivostok and the Russian attack on Gensan can not, in view of the diversity of opinion and practice which exists on this head, be unqualifiedly characterized as a violation of the law of nations, it is certainly not in conformity with the best practice and with the law which undoubtedly should prevail. They appear to have been justified by no pressing military necessity and are utterly antagonistic to the demands of modern humanitarianism and enlightened public opinion.

On the occasion of the bombardment of Vladivostok on March 6, I904, Admiral Alexieff accused the Japanese of using shells charged with lyddite $;^{51}$ but it was asserted in Tokio that the condition of the wounded Russians in Japanese Red Cross hospitals conclusively disproved such allegations, ${ }^{52}$ and a high officer in the Russian navy is quoted as having stated that "the accusation against the Japanese of using explosives to produce poisonous gases is based on a misconception. They are employing the same explosives as other armies and navies. It is notorious that the bursting of a melanite shell between decks generates fumes from which the men are liable to asphyxiation, but the Russian shell is no better and no worse than that used by the Japanese." ${ }_{53}$ In view of the fact that very little more was heard concerning the use of such shells, it may be taken for granted that very few, if any, were used by either belligerent during the war. ${ }^{54}$

${ }^{81}$ London Times (weekly) for March II, I904, p. I62.

${ }^{3}$ Associated Press Dispatch in Chicago Record-Herald for March 13, 1904.

${ }^{53}$ See N. Y. Times for March I8, 1904.

"On July I, I904, General Mistchenko reported from Liao-Yan that his cavalry had experienced the effects of lyddite shells employed by the Japanese. N. Y. Times for July 2, 1904. 
The Russians, on the other hand, were accused of using dumdum bullets. The London Times Correspondent at Tokio said in July, I9O4, ${ }^{\text {SS }}$ that it "appears to be clearly proved that the Russians in Manchuria are using dumdum bullets," and, in a dispatch dated September I I, Marquis Oyama stated that "among the ammunition abandoned by the Russians at Liao-Yang, were two kinds of dumdum bullets, each resembling those for the 1891 pattern Russian rifle." Although no rifles which could possibly have fired these bullets were found, and although the Japanese were unable to say positively that any of the wounds received by their men had been made by dumdum bullets, General Oyama asserted that the "fact of the existence of the bullets is uncontrovertible." ${ }^{56}$ In reply to these charges, the Russians appear to have maintained that the Japanese had made the mistake of confounding dumdum bullets "with the bullets used by the Russians in their quick-firing guns." 57

Although these charges against the Japanese of the use of lyddite shells, as well as the counter-charges against the Russians of the employment of dumdum bullets, appear to rest upon an insufficient amount of evidence, ${ }^{68}$ they may serve to recall the three Declarations of the Hague Conference, which are as follows:

I. "The Contracting Powers agree to prohibit, for a term of

* See London Times (weekly) for July 29, 1904.

* N. Y. and London Times for September 12, 1904 For confirmation of Marshall Oyama's statement, see De Forest in the N. Y. Independent for Oct. 5, 1905, p. 795.

${ }^{\text {si }}$ St. Petersburg Dispatch in London Times (weekly) for September 23, 1904, p. 612.

"It must, however, be admitted that the evidence in support of the Japanese charges against the Russians is much stronger than that in support of the Russian charges against the Japanese. 
five years, the launching of projectiles and explosives from balloons, or by other methods of a similar nature." 59

2. "The Contracting Powers agree to abstain from the use of bullets which expand or flatten easily in the human body, such as bullets with a hard envelope which does not entirely cover the core, or is pierced with incisions."

3. "The Contracting Powers agree to abstain from the use of projectiles, the object of which is the diffusion of asphyxiating or deleterious gases." 0

The Russian and Japanese rules and regulations appertaining to the treatment of prisoners of war have been given in the previous chapter. They seem to show excellent in-

${ }^{B 0}$ This agreement terminated on July 29, 1904, but neither of the belligerents appear to have taken advantage of this fact during the remainder of the war.

"Holls, Peace Conference, pp. 377, 455, 459, 461, 489. England did not sign any of these Declarations and the United States only signed the first. Captain Crozier, one of the representatives of the United States, proposed the following formula as a substitute for the second Declaration: "The use of bullets which inflict wounds of useless cruelty, such as explosive bullets and in general every kind of bullet which exceeds the limits necessary for placing a man immediately hors de combat, should be forbidden; but the Conference refused even to vote upon this amendment. For the defence by Great Britain of her use of the dum-dum bullet and the views of Captain Crozier, see Holls, pp. 98117 and 5II-514. Charges against Great Britain of the employment of lyddite shells as well as dum-dum bullets were made by General Joubert during the Boer War. On January 13 , 1900, a note, published in the English journals, informed the world that the British Government had decided, in deference to the Hague Convention, to stop the manufacture of such bullets. It is still a matter of controversy between English and Continental publicists as to whether the use of dum-dum bullets is or is not a violation of the Declaration of St. Petersburg of 1868 , the preamble of which declares the "employment of arms which uselessly aggravate the sufferings of disabled men, or render their death inevitable," to be "contrary to the laws of humanity." For the Continental view, see especially Bonfils-Fauchille, \& ro69; Desjardins in Revue des Deux Mondes for Mars-Avril, 1900, pp. 44 ff; Despagnet, La Guerre Sud-Africaine, pp. Io $\mathrm{ff}$ and $2 \mathrm{II} \mathrm{f}$; and De Lapradelle in Revue Générale de Droit International Public, VI (1899), pp. 691-700. 
tentions on both sides, and are certainly in conformity with the principles of International Law. Let us now see in what spirit and with what degree of good faith these rules were carried out.

All the witnesses who have given evidence (and they are numerous) ${ }^{61}$ speak in the highest terms of the treatment of Russian prisoners, and especially of the sick and wounded, on the part of the Japanese. This "pagan" nation of warriors appears indeed to have set up new standards of International Law and morality in this respect for the future guidance and imitation, let us hope, of the so-called Christian nations of the West. Within a few weeks after the outbreak of the war Japan made arrangements for putting into operation the provisions of the Hague Conference for the treatment of prisoners. In addition to the Instructions of February 19, 1904, cited in the previous chapter, rules regulating the free transmission of letters, money orders, and other articles between prisoners and their friends in their own country were issued on March 3, and a Bureau of Information for the benefit of the prisoners and their friends was established in accordance with Article 14 of the "Hague Regulations Respecting the Laws and Customs of War on Land" on February 2I, 1904. This Bureau seems to have

${ }^{n} E$. g. George Kennan in the Outlook for September 10 and October 29, 1904; Alfred Stead in the Fortnightly Review for February, 1905; editorial in Chicago Tribune for July 2, 1905; summary of the report of the United States Minister at Tokio to the State Department at Washington in N. Y. Times for April 29, 1904; Special Cablegram to the London Times for May 17, 1904; Tokio Dispatch to N. Y. Times for June 27, 1904; passage from letter from a Russian naval officer, published in London Times (weekly) for July I, 1904; Mrs. C. F. McWilliams in Harper's Weekly for September 30, 1905; Special to the N. Y. Times on July 24, I904; Art. on "Foreign Affairs," by Dr. E. J. Dillon in Contemporary Review for August, 1904, pp. $286 \mathrm{ff}$. 
worked well and to have given entire satisfaction to the Russian prisoners and their friends. Every ten days the French Minister at Tokio, who was charged with the protection of Russian interests in Japan, is said to have received lists of the Russian dead, wounded, and prisoners (so far as these were known), and to him was delivered the property of the dead. ${ }^{62}$

Referring to the kind treatment by the Japanese of the Russians on the Yalu early in May, 1904, a special cablegram to the London Times for May 17, 1904, says: "Those in the hospital are most carefully treated. Their lodging is superior to that of the Japanese wounded. The Japanese guards fraternize with their charges and show active sympathy, spending their microscopic pay for cigarettes for the prisoners." Referring to the considerate conduct of the Japanese in behalf of the friends of those Russians who had been killed in battle, a St. Petersburg dispatch to the London Times, dated October 12, 1904, says: "The General Staff now regularly receives through the intermediary of the French Embassy in St. Petersburg large numbers of carefully fastened packets which are forwarded by the Japanese military authorities. They contain objects of value of all kinds, such as jewels, cigar cases, purses, watches, gold crosses and sums of money (sometimes even single rouble pieces) found by the Japanese on the bodies of Russian officers and soldiers buried by them after battles. The receipt of the packets constitutes an irrefutable proof of the falseness of the statements which have found credence here to the effect that the Japanese despoil the dead and wounded on the battlefield. The same scrupulous regard is shown in

${ }^{82}$ N. Y. Times for July $25,1905$. 
the hospitals and prisons in which Russian prisoners in Japan are confined." 33

One of our most impartial and capable witnesses, George Kennan, ${ }^{\circ 4}$ testifies that "Japan treats the wounded soldiers of her enemy better, in some respects, than her own. They are humanely dealt with on the battefield and skilfully cared for in the hospitals; their daily ration is more generous than that of wounded Japanese; their mail goes without postage, and packages for them pay neither customs duty nor freight; and detailed statements of their condition in respect to health are made at short intervals to the French Legation for transmission to Russia."

In speaking of the Japanese attack on Port Arthur and of the terms of the surrender and taking over of that fortress, Mr. Alfred Stead ${ }^{65}$ does not hesitate to say that "the Japanese have set up new standards of conduct, new rules of international morality for the world." $\mathrm{He}$ considers the Japanese treatment of the Russian sick and wounded to have been "beyond criticism," and in support of this view he makes the statement that before the fall of Port Arthur the Japanese medical authorities had prepared stores for 20,000 men. This in spite of the fact that several Russian officers had broken their parole and that hundreds of Japanese

* The scrupulous care shown by the Japanese in returning the effects of the Russian dead, found on the battlefield, was highly commended by the Manchurian Army Vestnik, a newspaper published at the Russian theater of war under the sanction of the Russian officials. It announced that General Kuropatkin had recommended to his commanders the observance of a similar practice regarding the Japanese dead. See the Chicago Tribune for November 16, 1904.

" In the Outlook for October 29, 1904.

* See the Fortnightly Review for February, 1905. 
wounded in the fierce assaults on Port Arthur appear to have died in consequence of neglect on the part of the Russians. ${ }^{\circ 6}$

It appears that not only were the Russians confined in Japanese prisons and hospitals provided with all necessary material, comforts and conveniences, but that facilities were afforded for recreation and instruction. They had cards, music, and plenty of exercise, and schools were opened in which languages were taught and lessons in sanitation given. $^{67}$

Of the Russian treatment of Japanese prisoners, less is apparently known than of the Japanese treatment of Russian prisoners. From such evidence as we have, it appears, however, that those Japanese prisoners who fell into the hands of the Russians were, as a rule, well cared for, ${ }^{68}$ except at Port Arthur.

During the summer months of the year 1904 there was considerable complaint on the part of the Japanese because of the failure of the Russians to furnish them (the Japanese) with information concerning their prisoners, ${ }^{\circ 9}$ although it

* See the remarkable dispatch in the London Times for April 22, 1905, from its Tokio Correspondent. See also the comments of the London Spectator for April 29, 1905.

" See especially an article in Harper's Weekly for September 30, I905, by Mrs. C. F. McWilliams, entitled, "What Russia Has to Pay For."

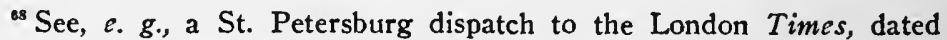
May 27, 1904; and the Army Order issued by General Kuropatkin, reported in N. Y. and London Times for June 30, 1904.

${ }^{\circ}$ For example, a Washington dispatch to the London Times (weekly) for July 29, 1904, states that "in spite of repeated requests, Mr. McCormick, the United States Minister at St. Petersburg, had been unable to obtain the names of Japanese prisoners who had been wounded and captured in the assaults on Port Arthur. This was not the only instance in which the efforts of our Legation at St. Petersburg appear to have been unavailing. 
would appear that a Prisoner's Bureau had been established in St. Petersburg under the Presidency of Professor de Martens as early as May 5, I904. ${ }^{70}$ An arrangement betweeen the Prisoners' Bureaus in Tokio and St. Petersburg was finally concluded in the latter part of September, 1904. It provided that information regarding the Japanese prisoners in the custody of Russia be communicated to the Japanese Legation in Berlin by the St. Petersburg Bureau, and that information regarding the Russian prisoners in Japan be communicated to the Russian Legation in Peking. ${ }^{71}$

Our review of the relations of the belligerents with each other during the Russo-Japanese War has shown that, while there were a considerable number of alleged violations of the rules of civilized warfare, especially on the part of Russia, these rules were on the whole fairly well observed by both belligerents. The violations, even when proven, were wholly exceptional and were comparatively few in number and of minor importance considering the duration of the war and the magnitude and vigor of military operations. In this respect this war ranks perhaps as high as any in history with the possible exception of the Spanish-American War. Russia was much more regardful of the rights of belligerents than of those of neutrals, and Japan not only set a high and, in some respects, new standard of International Law and morality, and her conduct won for her words of praise and admiration from the enemy. "They are a most valorous foe," General Kuropatkin is reported to have said to a war correspondent, "and are most correct in observing the arts

"See N. Y. Times for June 27, 1904.

${ }^{71}$ See London Times (weekly) for September 30, 1904. No further complaints appear to have been made. 
of war. In the latter respect it is the most agreeable war I have ever experienced." 72

As in the war with China, Japan sent trained international jurists with each army corps to act as advisors on International Law. Her conduct throughout the war was marked by the utmost regard for the forms and precedents as well as the principles of the law of nations, and she showed the most scrupulous regard for the rights of non-combatants, and of prisoners, more especially of the sick and wounded of the enemy.

"See the Chicago Tribune for October 16, and N. Y. Times for October 17, 1904. For other Russian tributes to the valor and humanity of the Japanese, see the London Times (weekly) for October 21 and November 25, 1904, pp. 677 and 755 . 


\section{CHAPTER XII}

The Relations Between England and the United States as Affected by the Far Eastern

Question and the War

It is the purpose of this chapter to try to show how the cooperation of England, Japan and the United States in the Far East has strengthened the friendship between England and the United States so auspiciously formed during the Spanish-American War.

Among the many remarkable volte-faces in the history of international relations, none is perhaps more interesting in itself or destined to be more far-reaching in its ultimate effects on the future of civilization than the changed attitude toward each other of the peoples and Governments of England and the United States during recent years. Only a decade ago the American people, almost to a man, were roused to a frenzy of patriotic fervor by President Cleveland's startling message of December, 1895, threatening England with war unless she consented to submit a boundary dispute between herself and Venezuela to arbitration. It then seemed as if the spirit of hatred and suspicion against England transmitted to us by our forefathers would never die out. This spirit had been kept alive after the wars of the Revolution and of 1812 by a variety of real and imaginary grievances, including trade rivalries and boundary disputes, and it was again renewed after the Civil War as a result, among other things, of the Alabama and Bering Sea controversies. 
But a great change for the better has taken place in the relations between the two greatest branches of the so-called Anglo-Saxon race, or rather between the parent trunk and its largest branch. There now exists an unspoken, but genuine friendship, based upon mutal sympathies and interests, between the peoples of England and the United States. Although this silent understanding has as yet found no adequate expression, either in words or acts, it has affected the formal relations between the two Governments, and is stronger in purpose and wider in scope than mere words or a formal agreement could possibly make it. There is a growing conviction in both countries, not merely that each Power will, in the future, refrain from attempting to injure the vital interests of the other, but that neither would permit serious harm to the other at the hands of a third Power, and that both will try to work together in friendly: rivalry at the solution of the great problems set by modern civilization.

It may not be out of place, however, before entering upon our main theme, to emphasize the fact that, as far as the people of the United States are concerned, this friendship or change of heart-a change of heart amounting almost to a conversion-had its main source or origin in the friendly and sympathetic attitude toward us assumed by the people and Government of Great Britain during the Spanish-American War. During that war it apparently dawned upon the people of the United States for the first time that, among European peoples, the English alone had any real sympathy with, or even understanding of, our actual aims and motives in undertaking to drive the Spaniards out of Cuba. Although England's sympathy with our policy during the Spanish-American War was not reciprocated by us during 
the Boer War, the attitude of our Government was perfectly correct during that struggle, and the interests of Great Britain in South Africa were entrusted to the American Consul at Pretoria, as the interests of the United States had been entrusted to the British legation at Madrid during the previous war. ${ }^{1}$

The acquisition of the Philippine Islands at the close of the Spanish-American War gave us a definite foothold and greatly increased our interests in the Orient, and imposed upon us some of the burdens and responsibilities of an Asiatic Power. At that time (in 1898 ) China was in process of partition or dismemberment into "spheres of interest" and "leases" by leading European Powers. The influence of Russia was then all-powerful at Peking; for, as a result of her successful intervention in the Chino-Japanese War and by guaranteeing a four per cent. loan to China of $400,000,-$ ooo francs, Russia had placed China under a debt of fear and gratitude.

Following the example of Germany, who had exacted from China the lease of the Bay of Kiao-chau along with valuable mining and railway privileges in the province of Shan-tung as indemnity for the murder of two German priests, and using this bad example as a pretext, Russia had secured, on March 27, I898, the lease of Port Arthur, and also the concession of a new railway in southern Manchuria in addition to the valuable concessions which she had already obtained in 1896 .

Great Britain did not even enter a formal protest against these immoral and high-handed proceedings $;^{2}$ but in order

\footnotetext{
${ }^{1}$ See House Doc. (Foreign Relations for 1899), pp. 349-351.

${ }^{2}$ Great Britain failed to secure the opening of Port Arthur to the world, but Dalny was made an open port. On January 17, 1898,
} 
to restore the balance of power on the Gulf of Pe-chi-li," the British Government leased and occupied Wei-hai-wei, opposite Port Arthur,-an act which, be it said in passing, met with the approval of Japan. ${ }^{3}$ France also demanded and obtained as her share of the spoils the lease of the Kwangchau Bay in southern China.

The principle of the territorial integrity of the Chinese Empire had thus been violated in the most open and flagrant manner by Germany, Russia, and France; and Great Britain, too, had been, albeit reluctantly, forced to follow suit and abandon her weak and apparently half-hearted attempts to uphold that policy in the Far East. On April 28, 1899, England even entered into an agreement with Russia engaging "not to seek for her own account, or on behalf of British subjects or of others, any railway concessions to the north of the Great Wall of China, and not to obstruct, directly or indirectly, applications for railway concessions in that region supported by the Russian Government." Russia, on

Sir Michael Hicks-Beach, then Chancellor of the Exchequer, had declared emphatically in a public speech that the door must not be closed in China. He said that the British Government did "not regard China as a place of conquest or acquisition by any European or other Power," and that it was "absolutely determined at whatever cost, even-and I wish to speak plainly-if necessary at the cost of war, that the door shall not be shut." See London Times for January 18, 1898. In a communication to Sir N. O'Conor, dated March 28, 1898, Lord Salisbury said: "Speaking generally, it may be said that the policy of this country is effectively to open China to the commerce of the world and that our estimate of the action of other Powers in the Far East depends on the degree to which it promotes or hinders the attainment of this object. It follows from this that the occupation of territory by foreign Powers is to be judged by the results, direct and indirect, immediate and remote, which it is likely to have on the commercial interest of the world, and the right of all nations to trade within the limits of the Chinese Empire on equal terms." Blue Book on China, No. I (1898), No. 133.

'China, No. I (1899), Nos. 35, 49, 79, 8I, 107, etc. 
her part, engaged, in similar terms, not to seek any railway concessions in the basin of the Yang-tse in behalf of Russian subjects. ${ }^{*}$

On October 16, I900, while she was still engaged in her struggle with the Boers, England even entered into an agreement with Germany in which, it is true, both Powers disclaimed territorial designs upon China and mutually engaged to uphold the principle of the open door there; but it was also stipulated that "in case of another Power making use of complications in China in order to obtain under any form whatever such territorial advantages, the two Contracting Parties reserve to themselves the right to come to a preliminary understanding as to the eventual steps to be taken for the protection of their own interests in China. ${ }^{5}$ By this agreement the principle of a balance of power in the Far East was practically suggested as a possible alternative or substitute for that of territorial integrity.

It will thus be seen that China was in sore need of a champion $^{6}$ when Secretary Hay stepped out upon the arena of Asiatic politics and issued his now famous Circular Note of September 6, 1899 , to the Powers in order to "maintain an open market for all the world's commerce and to remove dangerous sources of international irritation." Mr. Hay

- For the text of the Anglo-Russian Agreement, see China, No. 2 (1899), No. 138. See also Beveridge, The Russian Advance, Appendix, pp. 48I ff., and Hosie, Manchuria, pp. 64-65.

- For this agreement and the correspondence relating thereto, see China, No. 5 (1900), No. I.

- In 1898-99 China, or rather British interests in China, found a strong champion in Lord Beresford, who published the results of his investigations and observations in China in 1899 . His work, which appears to have been widely read, bore the significant title, "The Break-up of China." Lord Beresford's mission, which was of an essentially commercial character, was, however, not an official one. 
instructed our American representatives abroad to endeavor to obtain from each of the Powers claiming "spheres of interest" in China formal assurances to the following effect: (I) that it would not interfere with any treaty port or with the vested interest of any nation within a so-called "sphere of interest" or leased territory which such nation might have in China; (2) that it would maintain the Chinese treaty tariff (except in "free ports") under Chinese management, $i$. e., to guarantee equality of treatment for all nations under the most favored nation clause; and (3) that there shall be equality of treatment for all nations in respect to harbor dues and railroad charges. ${ }^{7}$ By March 20, 1900, favorable replies from all the Powers concerned-Great Britain, Germany, France, Italy, Russia, ${ }^{8}$ and Japan-had

${ }^{7}$ See House Doc., Foreign Relations (1899), 56th Congress, first session. pp. I3I ff.

${ }^{8}$ The reply of Russia had not been without a significant reservation. "As to the ports now cpened, or hereafter to be opened to foreign commerce by the Chinese Government, and which lie beyond the territory leased to Russia, the settlement of the question of customs duties belongs to China herself, and the Imperial Government (of Russia) has no intention whatever of claiming any privileges for its own subjects to the exclusicn of other foreigners." But "in so far as the territory leased by China to Russia is concerned, the Imperial Government (of Russia) has already demonstrated its firm intention to follow the policy of the 'open door' by creating Dalny (Ta-lien-wan) a free port; and if at some future time that port, although remaining free itself, should be separated by a custom-limit from other portions of the territory in question, the custom duties would be levied, in the zone subject to the tariff, upon all foreign merchandise without distinction as to nationality." All the Powers except Italy made their assent to the desired declarations conditional upon a similar assent on the part of all the other interested Powers. The reply of Great Britain was the most explicit and comprehensive, for she specifically included "the leased territory of Wei-haiwei and all territory in China which may hereafter be acquired by Great Britain by lease or otherwise, and all spheres of interest now held or that may hereafter be held in China." See House Doc., cited above. 
been received, and $\mathrm{Mr}$. Hay was able to announce that the consent of each nation consulted would be considered "final and definite."

In his communication of September 22, 1899, to Lord Salisbury, our ambassador at the Court of St. James, Mr. Choate, called special attention to the fact that the interests of England and the United States in the maintenance of trade and commerce in the Far East differed "not in character, but in degree only," and he observed that our President conceived such action as that asked for "to be in exact accord with the uniformly declared policy and traditions" of Great Britain. "He (the President) understands it to be the settled policy and purpose of Great Britain not to use any privileges which may be granted to it in China as a means of excluding any commercial rivals, and that freedom of trade for it in that empire means freedom of trade for all the world alike. Her Majesty's Government, while conceding by formal agreements with Russia and Germany the possession of 'spheres of influence or interest' in China, in which they are to enjoy special rights and privileges, particularly in respect to railroads and mining enterprises, has at the same time sought to maintain what is commonly called the 'open door' policy, to secure to the commerce and navigation of all nations equality of treatment within such 'spheres.' The maintenance of this policy is alike urgently demanded by the commercial communities of our two nations, as it is justly held by them to be the only one which will improve existing conditions, enable them to maintain their positions in the markets of China, and extend their future operations."

- Blue Book on China, No. 2 (1900), No. I. Cf. House Doc., cited above. 
On July 3, 1900, during the crisis caused by the Boxer uprising, Secretary Hay addressed to the Powers a second Circular Note in which he said: "The purpose of the President is, as it has been heretofore, to act concurrently with the other Powers, first, in opening up communication with Peking and rescuing American officials, missionaries, and other Americans who are in danger; secondly, in affording all possible protection everywhere in China to American life and property; thirdly, in guarding and protecting all legitimate American interests; and fourthly, in aiding to prevent a spread of the disorders to the other provinces of the Empire and a recurrence of such disasters. It is, of course, too early to forecast the means of attaining this last result; but the policy of the Government of the United States is to seek a solution which may bring about permanent safety and peace in China, preserve Chinese territorial and administrative entity, ${ }^{10}$ protect all rights guaranteed to friendly Powers by treaty and International Law, and safeguard for the world the principle of equal and impartial trade with all parts of the Chinese Empire." ${ }^{11}$ This note met with a most cordial reception on the part of the Powers to whom it was addressed, and it appears to have been a potent factor in the re-establishment of order in China and the restoration of peace between China and the Powers.

During the Boxer uprising of 1900 , as also during the long negotiations which followed, all the Powers interested in the fate of China repeatedly pledged themselves to maintain the 'open door' and the territorial integrity of the Chinese Empire. The latter principle was especially urged by

\footnotetext{
${ }^{10}$ The italics are the author's.

${ }^{11}$ House Doc., Foreign Relations (1900), 56th Congress, second Session, pp. $299 \mathrm{ff}$.
} 
Russia, but was at the same time being violated by her in Manchuria, which was overrun and occupied by Russian troops.

During the campaign of 1900 , as also during the negotiations which led up to the signing of the Peace Protocol of September 7, rgor, between China and the allied Powers, the relations between England, Japan, and the United States were particularly close and they appear, in the main, to have acted in harmony. ${ }^{12}$

The support of the United States and Japan ${ }^{13}$ aided Great Britain in checking the aggressive tendencies of Russian policy in northern China during this period, and this assistance must have been especially gratifying to England at a time when she was engaged in her great struggle with the Boers in South Africa. For had England been compelled

${ }^{22}$ So, $\varepsilon$. g., in July, 1900, the British and American Admirals voted against the proposal to give Russia the control of the railway line from Tongku to Tientsin, which the Russians had seized and were operating in spite of the fact that it was mortgaged to British bondholders. On the strength of the decision of the Admirals, the Russians claimed the whole railway from Taku to Peking. Russian and British troops almost came to an open conflict at one stage of this dispute. See China, No. 7 (I901), passim, especially No. 4. The United States was particularly active in securing a reduction of the amount of indemnity imposed upon China. The United States and Great Britain both strongly opposed the Russo-French proposal of a joint guaranteed loan. See China, No. 1 (1902), passim, especially Nos. 136 and 173 .

On the other hand, the United States, Russia and Japan opposed the extreme demands of England and Germany on the Chinese Government in the matter of the capital punishment of Prince Tuan, Duke Lan, and Tung-fu Hsiang. See China, No. 6 (I90I), passim, especially Nos. $55,57,67,83,119,135,141,172,193,205$ and 233.

${ }^{23}$ The policy of Japan appears at this time to have been much less aggressive than it was a few years later. Inasmuch as Japan furnished more than her proportion of troops for the relief of the Legations at Peking during the Boxer uprising, her Government asked for and received financial assistance from England. See China, No. 3 (1900), Nos. 265 ff. 
to fight the battle of the open door and territorial integrity of China alone during this crisis in her history, she must inevitably have yielded to a coalition between Russia, France, and Germany, who would probably have siezed this favorable opportunity to continue or complete the process of dismembering the Chinese Empire which they had so successfully begun a few years before. In that case, the gates of China would have been closed to the rest of the world and the greater part, at least, of the immense potential resources of that vast country and its teeming population must have fallen a prey to the systematic commercial exploitation and exclusive protective systems of these countries. ${ }^{14}$

In February, I90I, Japan, Great Britain, and the United States made similar representations to China against her signing the Alexieff-Tsêng Agreement for the pacification of Manchuria. The United States, e. g., reminded China of the "impropriety, inexpediency, and even extreme danger to the interests of China, of considering any private territorial and financial engagements, at least without the full knowledge and approval of all the Powers now engaged in negotiations."1s In reply to an appeal from the Emperor

${ }^{14}$ On March 15, I901, the German Chancellor openly declared in a speech in the Reichstag that "there were no German interests of importance in Manchuria," and that "the fate of that province was a matter of absolute indifference to Germany." But he added that Germany had informed China that "she would deprecate the conclusion at the present time of any agreement with no matter which Power, which would impair China's financial resources." Cited by McCarthy, The Coming Power, p. 105. Cf. Scott to Lansdowne in China, No. 6 (Ig01), No. 211. Of course, Germany would have demanded concessions elsewhere in China in return for her complaisance toward Russia in Manchuria. The relations between Russia and France during this period are too well known to admit of any doubt as to the attitude of France.

${ }^{15}$ China, No. 2 (1904), No. 19. See also Nos. 8 and 15 for the attitude of Great Britain and Japan. Germany also made representations to 
of China, Great Britain and Japan remonstrated in March, I90I, against the signing of the drastic Lamsdorff-Yang-yu Convention, which would probably have resulted in the complete Russianization of Manchuria. ${ }^{10}$

On February 3, I902, Secretary Hay lodged a vigorous protest against the terms of a proposed agreement between Russia and China according to which the Russo-Chinese Bank was to be given a practical monopoly of all railway and mining concessions in Manchuria. It is highly probable that similar protests were made by Great Britain and Japan, but no reference to such action appears in the published documents. ${ }^{17}$ There can be no doubt, however, that Secretary Hay's protest was in accordance with the views of these two Powers. ${ }^{18}$ He reminded the Russian and Chinese Governments of the repeated assurances given by Russia of her devotion to the principle of the "open door" in China, and said: "The Government of the United States can view only with concern an agreement by which China concedes to a corporation the exclusive right to open mines, construct railways, or other industrial privilege; that such monopoly would distinctly contravene treaties of China with foreign Powers, affect rights of citizens of the United States by re-

China on this occasion, but with greater reservation and in somewhat different language. See China, op. cit., Nos. 12 and I3.

${ }^{10}$ China, No. 6 (I901), Nos. 202 and 207. See also China, No. 2 (1904), Nos. I6, 21, 24, 28, 34, etc. The United States does not seem to have remonstrated on this occasion. At least such action does not appear in the published documents. She probably considered her former representations sufficient for the purpose.

${ }^{27}$ Asakawa (The Russo-Japanese Conflict, p. 194) calls attention to this fact.

${ }^{18}$ The attitude of the British Government was clearly indicated in a conversation between Lord Lansdowne and Mr. Choate on February II, I902. See Mr. Choate to Mr. Hay in House Doc. of 57 th Congress, 2d session (For. Rel. 1902-03), pp. 5 I I-I2. 
stricting rightful trade, and tend to impair the sovereign rights of China and diminish her ability to meet international obligations; that other Powers will probably seek similar exclusive advantages in other parts of the Chinese Empire, which would wreck the policy of absolutely equal treatment of all nations in regard to navigation and commerce in the Chinese Empire; and that, moreover, for one Power to acquire exclusive privileges for its nationals conflicts with assurances repeatedly given to the Government of the United States by the Russian ministry for foreign affairs of a firm intention to follow the policy of the open door in China, as advocated by the United States and accepted by all the Powers having commercial interests in China." 19

The situation in the Far East was greatly affected by the defensive alliance between England and Japan, signed on January 30, 1902. This alliance was induced by the discovery, as the result of frequent interchanges between the two Governments, that "their Far Eastern policy was identical," and it declared for the open door and the territorial integrity of the Chinese Empire. ${ }^{20}$ It greatly strengthened the hands of both Governments in dealing with China and Russia, and, although the United States made no declaration to that effect, ${ }^{21}$ it was well known that our sympathies

${ }^{10}$ Paraphrase of telegram to Mr. Conger on February II, I902. See House Doc., of 57th Congress, 2d session, pp. 275-76. Cf. Ibid., pp. 926-28.

${ }^{20}$ Lord Lansdowne to Sir Claude MacDonald, The British Parliamentary Papers for Japan, No. I (1902).

${ }^{21}$ The United States Government officially disclaimed all knowledge of the negotiations between Great Britain and Japan leading up to the Anglo-Japanese Agreement; but in a memorandum, dated March 22, 1902, it expressed its gratification in seeing in the Russo-French Declaration of March 16, 1902, as also in the Anglo-Japanese Agreement, 
and interests were also "identical" with those of Great Britain and Japan in the Orient.

This Agreement appears to have had the desired effect. On April 8, 1902, Russia concluded with China the now famous Convention providing for the gradual evacuation of the whole of Manchuria in three successive withdrawals within eighteen months after the date of agreement, "provided that no disturbances arise and that the action of other Powers place no obstacle" in the way of such withdrawal. ${ }^{22}$

After a very incomplete fulfillment of her engagement to withdraw from Manchuria, ${ }^{23}$ Russia made seven additional demands upon China in April, 1903, as a condition for the completion of the process of evacuation. These were of a highly exclusive nature, and included stringent measures for closing Manchuria to the economic enterprises of all foreigners except Russians and for preventing the opening of new treaty ports in Manchuria without the consent of Russia. ${ }^{24}$ These demands were in direct opposition to the principle of the "open door," and their publication was followed by firm representations on the part of Japan, Great Britain, and the United States. ${ }^{25}$

"renewed confirmation of the assurances it has heretofore received from each of them regarding their concurrence with the views which this Government has from the outset announced and advocated in respect to the conservation of the independence and integrity of the Chinese Empire as well as of Korea, and the maintenance of complete liberty of intercourse between those countries and all nations in matters of trade and industry." See House Doc., 57th Congress, 2d session, pp. 930-31.

$=$ The italics are the author's. For the French text and English translation of this Convention, see Blue Book on China, No. 2 (1904), Nos. 54 and 51 .

${ }^{23}$ See Introduction, supra, pp. 33-34.

« For these demands, see supra, pp. 34-35.

${ }^{2}$ China, No. 2 (1904), Nos. $79 \mathrm{ff}$. In a communication, dated April 
An important step in the direction of strengthening the "open door" policy in China was taken by the United States on October 8, 1903-the date which had been set for the final evacuation of Manchuria. On that date the United States concluded a commercial treaty with China which secured the opening of Mukden and Antung in Manchuria to international trade and settlement in spite of Russian opposition. ${ }^{26}$

It was in strict accordance with a number of precedents that Secretary Hay took the initiative on February Io, 1904, in proclaiming that "the neutrality of China and in all practicable ways her administrative entity ${ }^{27}$ should be respected by Japan and Russia during the Russo-Japanese War. Although this proposal was said to have been made at the suggestion of Germany, the burden of enforcing it against Russia would undoubtedly have fallen upon Great Britain and the United States had such action become nec-

28, 1903, to Sir Herbert, Lord Lansdowne said it was the "desire and intention" of the British Government "to act in accordance with what we conceive to be the policy of the United States, namely, to open China impartially to the commerce of the whole world, to maintain her independence and integrity, and to insist upon the fulfillment of treaty and other obligations by the Chinese Government which they have contracted towards us." Ibid., No. 90.

${ }^{26}$ On the same day (October 8,1903 ) a commercial treaty, providing for the opening to the world's trade of Mukden and Tatung-Kao, was concluded between China and Japan.

The attitude of Russia towards the rights and privileges of foreigners in Manchuria may be inferred from Count Benckendorff's admissions to Lord Landsdowne on July II, 1903. He said in effect that the "Imperial Government (of Russia) have no intention of opposing the gradual opening by China, as commercial relations develop, of some towns in Manchuria to foreign commerce, excluding, however, the right to establish 'Settlements'." China, No. 2 (1904), No. 133.

${ }^{27}$ House Doc., 58th Congress, 3d session (For. Rel. 1904), p. 2. Cf. supra, pp. 246-247. 
essary. While the attitude of the Governments of both these countries towards Russia was entirely correct during the war-more so, in fact, than was the conduct of France and Germany towards Japan-nevertheless the sympathies and good wishes of the people of the United States, as well as those of England, were enlisted on the side of Japan. Admiration for the splendid fighting qualities of the Japanese, a fear of the Russian Advance, a feeling that Japan was fighting our battle in the Far East, were sentiments common to the people of both countries. The Governments of both countries made similar protests against the Russian doctrine of contraband, and our leading newspapers took the English side in every important controversy which arose between Russia and Great Britain, as, e. $g$., in respect to the seizure of the Malacca, the sinking of the Knight Commander, and the North Sea Incident.

Our American traditions and principles forbid our becoming a party to the recent offensive and defensive alliance between England and Japan, ${ }^{28}$ but our sympathies and interests are clearly enlisted on the side of that partnership. There exists a gradually growing conviction that the interests of Great Britain and the United States in the Orient are identical. In their Far Eastern Policy both countries have aimed at the enlargement of commercial opportunities and the expansion of trade rather than at territorial aggrandizement or political control, whereas Russia, France, and Germany appear to have sought after "spheres of interest" and "leases" with a view to acquiring special economic privileges or commercial monopolies for themselves. All that the English and Americans ask for is a fair field and an

${ }^{28}$ See infra, pp. $357-359$. 
equal opportunity to enter into free and open competition with the other nations of the world for the markets of the East. In other words, the United States and England stand together in demanding a "square deal" in the Orient. 


\section{CHAPTER XIII}

\section{The Treaty of Portsmouth}

The Russo-Japanese War was ended by a treaty negotiated at Portsmouth, N. H., which was signed September 5 and ratified October 14, 1905. The terms of this treaty are as follows:

ARTICLE I. There shall henceforth be peace and amity between their Majesties, the Emperor of Japan and the Emperor of All the Russias, and between their respective states and subjects.

ART. II. The Imperial Russian Government, acknowledging that Japan possesses in Korea paramount political, military, and economical interests, engage neither to obstruct nor interfere with the measures of guidance, protection, and control which the Imperial Government of Japan may find it necessary to take in Korea.

It is understood that Russian subjects in Korea shall be treated in exactly the same manner as the subjects and citizens of other foreign Powers; that is to say, they shall be placed on the same footing as the subjects and citizens of the most favored nation.

It is also agreed that, in order to avoid causes of misunderstanding, the two High Contracting Parties will abstain on the Russo-Korean frontier from taking any military measures which may menace the security of Russian or Korean territory.

ART. III. Japan and Russia mutually engage:

(I) to evacuate completely and simultaneously Manchuria, except the territory affected by the lease of the Liao-tung Peninsula in conformity with the provisions of the additional Article I annexed to this treaty; and 
(2) to restore entirely and completely to the exclusive administration of China all portions of Manchuria now in occupation or under the control of the Japanese or Russian troops, with the exception of the territory above mentioned.

The Imperial Government of Russia declare that they have not in Manchuria any territorial advantages or preferential or exclusive concessions in the impairment of Chinese sovereignty or inconsistent with the principle of equal opportunity.

ART. IV. Japan and Russia reciprocally engage not to obstruct any general measures common to all countries which China may take for the development of the commerce or industry of Manchuria.

ART. V. The Imperial Russian Government transfer and assign to the Imperial Government of Japan, with the consent of the Government of China, the lease of Port Arthur, Ta-lien, and the adjacent territory and territorial waters, and all rights, privileges, and concessions connected with or forming part of such lease, and they also transfer and assign to the Imperial Government of Japan all public works and properties in the territory affected by the above-mentioned lease.

The two Contracting Parties mutually engage to obtain the consent of the Chinese Government mentioned in the foregoing stipulation. The Imperial Government of Japan on their part undertake that the proprietary rights of Russian subjects in the territory above referred to shall be perfectly respected.

ART. VI. The Imperial Russian Government engage to transfer and assign to the Imperial Government of Japan, without compensation and with the consent of the Chinese Government, the railroad between Chang-chun (Kuan-chang-tsu) and Port Arthur, and all its branches, together with all rights, privileges. and properties appertaining thereto in that region, as well as all coal mines in said region belonging to or worked for the benefit of the railway. The two High Contracting Parties mutually engage to obtain the consent of the Government of China mentioned in the foregoing stipulation.

ART. VII. Japan and Russia engage to exploit their respective railways in Manchuria exclusively for commercial and in- 
dustrial purposes and in nowise for strategic purposes. It is understood that this restriction does not apply to the railway in the territory affected by the lease of the Liao-tung Peninsula.

ArT. VIII. The Imperial Governments of Japan and Russia, with the view to promote and facilitate intercourse and traffic, will, as soon as possible, conclude a separate convention for the regulation of their connecting railway services in Manchuria.

ART. IX. The Imperial Russian Government cede to the Imperial Government of Japan in perpetuity and full sovereignty the southern portion of the Island of Sakhalin and all islands adjacent thereto and the public works and properties thereon. The fiftieth degree of north latitude is adopted as the northern boundary of the ceded territory. The exact alignment of such territory shall be determined in accordance with the provisions of additional Article II annexed to this treaty.

Japan and Russia mutually agree not to construct in their respective possessions on the island of Sakhalin or the adjacent islands any fortifications or other similar military works. They also respectively engage not to take any military measures which may impede the free navigation of the Straits of La Perouse and Tartary.

ART. X. It is reserved to Russian subjects, inhabitants of the territory ceded to Japan, to sell their real property and retire to their country ; but if they prefer to remain in the ceded territory they will be maintained and protected in the full exercise of their industries and rights of property on condition of submitting to the Japanese laws and jurisdiction. Japan shall have full liberty to withdraw the right of residence or to deport from such territory any inhabitants who labor under political or administrative disability. She engages, however, that the proprietary rights of such inhabitants shall be fully respected.

ART. XI. Russia engages to arrange with Japan for granting to Japanese subjects rights of fishery along the coasts of the Russian possessions in the Japan, Okhotsk, and Bering Seas.

It is agreed that the foregoing engagement shall not affect 
rights already belonging to Russian or foreign subjects in those regions.

ART. XII. The treaty of commerce and navigation between Japan and Russia having been annulled by the war, the Imperial Governments of Japan and Russia engage to adopt as the basis for their commercial relations, pending the conclusion of a new treaty of commerce and navigation on the basis of the treaty which was in force previous to the present war, the system of reciprocal treatment on the footing of the most favored nation, in which are included import and export duties, customs formalities, transit and tonnage dues, and the admission and treatment of agents, subjects, and vessels of one country in the territories of the other.

Art. XIII. As soon as possible after the present treaty comes into force all prisoners of war shall be reciprocally restored. The Imperial Governments of Japan and Russia shall each appoint a special commissioner to take charge of the prisoners. All prisoners in the hands of one Government shall be delivered to and received by the commissioner of the other Government or by his duly authorized representative in such convenient numbers and such convenient ports of the delivering state as such delivering state shall notify in advance to the commissioner of the receiving state.

The Governments of Japan and Russia shall present to each other, as soon as possible after the delivery of prisoners has been completed, a statement of the direct expenditures respectively incurred by them for the care and maintenance of the prisoners from the date of capture or surrender and up to the time of death or delivery. Russia engages to repay to Japan, as soon as possible after the exchange of the statements as above provided, the difference between the actual amount so expended by Japan and the actual amount similarly disbursed by Russia.

Arr. XIV. The present treaty shall be ratified by their Majesties, the Emperor of Japan and the Emperor of All the Russias. Such ratification shall, with as little delay as possible, and in any case not later than fifty days from the date of the signature of the treaty, be announced to the Imperial Govern- 
ments of Japan and Russia respectively through the French Minister at Tokio and the Ambassador of the United States at St. Petersburg, and from the date of the later of such announcements this treaty shall in all its parts come into full force. The formal exchange of ratifications shall take place at Washington as soon as possible.

ART. XV. The present treaty shall be signed in duplicate in both the English and French languages. The texts are in absolute conformity, but in case of a discrepancy in the interpretation the French text shall prevail.

In conformity with the provisions of Articles III and IX of the treaty of peace between Japan and Russia of this date, the undersigned plenipotentiaries have concluded the following additional Articles:

Sub-Article I to Article III. The Imperial Governments of Japan and Russia mutually engage to commence the withdrawal of their military forces from the territory of Manchuria simultaneously and immediately after the treaty of peace comes into operation; and within a period of eighteen months from that date the armies of the two countries shall be completely withdrawn from Manchuria, except from the leased territory of the Liao-tung Peninsula. The forces of the two countries occupying the front position shall be first withdrawn.

The High Contracting Parties reserve to themselves the right to maintain guards to protect their respective railway lines in Manchuria. The number of such guards shall not exceed fifteen per kilometer, and within that maximum number the commanders of the Japanese and Russian armies shall, by common accord, fix the number of such guards to be employed as small as possible while having in view the actual requirements.

The commanders of the Japanese and Russian forces in Manchuria shall agree upon the details of the evacuation in conformity with the above principles, and shall take by common accord the measures necessary to carry out the evacuation as soon as possible, and in any case not later than the period of eighteen months.

Sub-Article II to Article IX. As soon as possible after the 
present treaty comes into force, a commission of delimitation, composed of an equal number of members to be appointed, respectively, by the two High Contracting Parties, shall on the spot mark in a permanent manner the exact boundary between the Japanese and Russian possessions on the island of Sakhalin. The commission shall be bound, so far as topographical considerations permit, to follow the fiftieth parallel of north latitude as the boundary line, and in case any deflections from that line at any points are found to be necessary, compensation will be made by correlative deflections at other points. It shall also be the duty of said commission to prepare a list and a description of the adjacent islands included in the cession, and, finally, the commission shall prepare and sign maps showing the boundaries of the ceded territory. The work of the commission shall be subject to the approval of the High Contracting Parties.

The foregoing additional articles are to be considered as ratified with the ratification of the treaty of peace to which they are annexed.

Portsmouth, the fifth day of the ninth month of the thirtyeighth year of Meiji, corresponding to the twenty-third of August, 1905 (September 5, 1905).

In witness whereof the respective plenipotentiaries have signed and affixed seals to the present treaty of peace.

Done at Portsmouth, New Hampshire, this fifth day of the ninth month of the thirty-eighth year of the Meiji, corresponding to the twenty-third day of August, one thousand nine hundred and five. ${ }^{1}$

To the student of International Law and Diplomacy, this treaty is interesting and important mainly for three reasons : in the first place, because of the leading part played by President Roosevelt in inaugurating and influencing the conduct of negotiations; secondly, because of the controversy with regard to the question of indemnity; and thirdly, because,

${ }^{1}$ Reprinted from the London Times (weekly) for October 20, 1905, pp. $659-60$. 
taken in connection with the Anglo-Japanese offensive and defensive Alliance signed on August 12, $1905,{ }^{2}$ it settled, for a time at least, the status of the combatants (and incidentally, too, that of other leading nations of Europe and America) in the Far East.

Article 3 of the First Convention or Arbitration Treaty of the Hague Conference provides: "Independently of this recourse $(i . e$., recourse to the offices or mediation of friendly Powers before an appeal to arms), ${ }^{3}$ the Signatory Powers consider it useful that one or more Powers who are strangers to the dispute should, on their own initiative, and as far as circumstances will allow, offer their good offices or mediation to the states at variance. The right to offer good offices or mediation belongs to Powers who are strangers to the dispute, even during the course of hostilities. The exercise of this right shall never be considered by one or the other parties to the contest as an unfriendly act."4

There was some agitation in favor of peace after the fall of Port Arthur early in January, and again after the great battle of Mukden in March, but it was not until after the destruction of the Baltic Fleet in the Korean Straits, on May 27, 1905, that the Russian Government appeared to be in a mood favorable to the consideration of terms of peace. Accordingly, having received assurances from both combatants that his overtures would be well received, President Roosevelt, acting upon the recommendation of the Hague Conference above cited, took the initiative and, on June 8,

Infra, pp. 357-359.

- See Art. 2 of the Arbitration Treaty.

- For valuable and interesting comments upon these articles, see Holls, Peace Conference, pp. 176-185. 
1905, sent the following identical note to the Russian ${ }^{5}$ and Japanese Governments :

"The President feels that the time has come when, in the interests of all mankind, he must endeavor to see if it is not possible to bring to an end the terrible and lamentable conflict now being waged.

"With both Russia and Japan the United States had inherited ties of friendship and goodwill. It hopes for the prosperity and welfare of each, and it feels that the progress of the world is set back by the war between these two great nations.

"The President, accordingly, urges the Russian and Japanese Governments not only for their own sakes, but in the interest of the whole civilized world to open direct negotiations for peace with one another.

"The President suggests that these peace negotiations be conducted directly and exclusively between the belligerents; in other words, that there may be a meeting of Russian and Japanese plenipotentiaries or delegates without any intermediary, in order to see if it is not possible for these representatives of the two Powers to agree to terms of peace.

"The President earnestly asks that the (Russian) (Japanese) Government do now agree to such a meeting and is asking the (Japanese) (Russian) Government likewise to agree.

"While the President does not feel that any intermediary should be called in in respect to the peace negotiations themselves, he is entirely willing to do what he properly can if the two Powers concerned feel that his services will be of aid in arranging the preliminaries as to the time and place of meeting. But if even these preliminaries can be arranged directly between the two Powers, or in any other way, the President will be glad, as his sole purpose is to bring about a meeting which the whole civilized world will pray may result in peace."

\footnotetext{
-The action of President Roosevelt is said to have been supported by the German Emperor who, it was semi-officially stated, made independent representation to the Czar. See Berlin dispatch of June I 3 to the London Times.
} 
Favorable replies ${ }^{6}$ were received from both belligerents, but considerable difficulty was experienced in deciding upon a place of meeting. Russia appears to have suggested Paris as a suitable place for the negotiations and Japan proposed Che-Foo. ${ }^{7}$ In accordance with the preference of Japan, the United States was finally selected as the place of meeting during the first ten days of August, $1905 .{ }^{\circ}$ Washington seems to have been the first choice, but this was later changed to Portsmouth, N. H., as a more suitable location during the hot season.

As peace plenipotentiaries Russia selected two of her most eminent statesmen-the famous financier, M. Witte, ${ }^{8}$ and the experienced diplomatist, Baron Rosen, who had represented Russia at the court of Tokio at the outbreak of the war. Japan also sent two of her most eminent statesmenthe Foreign Minister, Baron Komura, and Mr. Takahira, Japan's able representative at Washington.

The Portsmouth Peace Conference held its first session, which was wholly devoted to civilities and formalities, on

- For these replies, see London Times (weekly) for June 16, 1905, p. 371. The reply of Russia was characteristically Russian. It declared that the "Imperial Government (of Russia) would have no objection in principle to such an attempt if the Japanese Government expressed a desire for it."

"The Hague was also suggested, but this proved unacceptable to Japan.

' China is said to have given notice that she would not recognize any arrangement which might be made regarding Chinese interests in Manchuria unless she was represented at the conference.

- The experienced diplomatist Nediloff and the Minister of Justice Muravieff were at first selected in M. Witte's place. Both of these gentlemen were excused on the diplomatic ground of ill-health. The eminent Russian publicist, De Martens, together with a number of other experts, accompanied the Russian plenipotentiaries to Portsmouth. The Japanese were similarly accompanied by number of experts and specialists. 
August 9. From the outset, it was generally held by those who were apparently best informed, that the conference was foredoomed to failure. ${ }^{10}$ The language question was settled by an agreement that English, French, or any other language might be spoken, each envoy using the language he preferred. The protocols, it was agreed, were to be drawn in both French and English, the French text, however, to be regarded as official or decisive in case of a question of interpretation. ${ }^{11}$

The twelve Japanese conditions of peace were handed to the Russian envoys at the second session of the Peace Conference on August Io. As a result of the insistence of the Japanese, who maintained throughout the conference an attitude of uncompromising opposition to publicity in any form, the Russians agreed, albeit reluctantly, that all discussions and proceedings were to remain secret. Nevertheless, the Japanese terms gradually leaked out. ${ }^{12}$

These twelve Japanese demands appear to have been substantially as follows :

(I) The recognition by Russia of Japan's paramount interests in Korea.

(2) An engagement on the part of Russia to completely evacuate Manchuria and to relinquish all territorial advantages and all preferential and exclusive concessions and franchises in that region which tended to impair Chinese sovereignty or were inconsistent with the principle of equal opportunity.

(3) An engagement on the part of Japan to restore to China all those portions of Manchuria which she had occupied, with

${ }^{10}$ See, e. g., the repeated predictions of failure made by Dr. Morrison, the famous correspondent of the London Times.

"See London Times for August 10, 1905.

${ }^{12}$ For this "leakage," M. Witte was generally held responsible. 
the exception of the regions affected by the lease of the Liaotung Peninsula.

(4) A mutual engagement on the part of Japan and Russia not to obstruct any general measures $(i . e$., common to all countries) which China may take for the development of the commerce and industries of Manchuria.

(5) The cession of Sakhalin to Japan.

(6) The transfer to Japan of the Russian leases of the Liaotung Peninsula, including Port Arthur and Talien (Dalny).

(7) The transfer to Japan of that portion of the Southern Manchurian Railway (together with its branches) connecting Harbin with Port Arthur, and of all coal mines appertaining thereto.

(8) The retention by Russia of the main line or latitudinal section of the Chinese Eastern or Trans-Manchurian railway, on condition that it be employed exclusively for commercial and industrial purposes.

(9) The demand for a war indemnity, or rather reimbursement for the costs of the war. The amount was not stated, but the costs of the war were variously estimated at from $\$ 500,000,000$ to $\$ 1,000,000,000$.

(I0) The surrender to Japan of all Russian warships interned in neutral ports during the war.

(II) The limitation of Russia's naval forces in the Far East.

(I2) The grant to Japanese subjects of certain fishing rights on the Siberian coast. ${ }^{13}$

Of these twelve demands, four (Arts. 5, 9, I0, I I) were positively rejected in the Russian reply, viz.-the cession of Sakhalin, the payment of a war indemnity, the surrender to Japan of the Russian warships interned in neutral ports, and the limitation of Russia's naval forces in the Far East.

${ }^{2}$ For the text of these demands, see two articles by Dr. E. G. Dillon entitled "The Official Narrative of the Peace Conference" and "The Story of the Peace Negotiations" in Harper's Wcekly for September 16, 1905, and Contemporary Review for October, 1905, respectively. 
Upon Baron Komura's suggestion, the Japanese conditions were considered scriatim, but it was soon learned that the Russians were firm in refusing these four demands. They seem to have been willing to yield or compromise on every point which might be regarded as a casus belli, but to have been unalterably opposed to further concessions.

As to Sakhalin, the Japanese rightly argued that they were in actual possession, and that, considering the fortunes of the war and the fact that the island formerly belonged to Japan, the rule of uti possidetis ought to prevail. The Russians, on the other hand, maintained that the cession of this "sentinel at our gate" to Japan would transform not only the Sea of Japan into a Japanese lake, but the Sea of Okhotsk as well. The retention of this island, they maintained, was of great defensive value to Siberia. In respect to the delivery of the interned Russian warships, the Russians correctly maintained that this was contrary to international precedent. ${ }^{14}$ As to the limitation of their naval forces in the Far East, the Russians rightly held that such a concession would be humiliating for them ${ }^{15}$ and derogatory to their honor and dignity. The utmost that M. Witte would concede on this point was a formal declaration to the effect that Russia had no present intention of increasing her fleet in Eastern waters. As to remuneration for the cost of the war,

${ }^{14}$ The Russians are represented as having said, "contrary to International Law," but they must have meant "international usage" or "precedent." Of course, there is no principle in International Law which would have forbidden such a transfer. But it has not been customary to exact such delivery.

${ }^{15}$ It is well known that Russia had been forced to make such a concession in respect to warships on the Black Sea at the close of the Crimean War in 1856 , but she had taken the first good opportunity which presented itself (in 1870 ) to remove this restriction upon her freedom of movement. 
M. Witte is reported to have said: "We will pay you what you have expended to do us good, all your outlays for the maintenance of prisoners and any expense in that nature which you will define to us. We will pay it gladly, liberally, and without question. But for what you have spent to do us evil一not a copeck."

It soon became apparent that the Japanese were not particularly bent on Articles Io and I I, but that they were determined to secure, if possible, the cession of Sakhalin and a large war indemnity. ${ }^{17}$ The Russians, on the other hand, absolutely refused to concede these demands. The conference seems to have been on the point of breaking up when President Roosevelt stepped into the breach and, on the night of August I8-I9, sent for one of the Russian plenipotentiaries to call upon him at his summer residence at Oyster Bay. What transpired at the interview between him and Baron Rosen on the following day (August 19) is unknown $;^{18}$ but it subsequently developed that the Japanese

${ }^{10}$ London Times (weekly) for August 25, 1905, p. 530. This phrase"not a copeck"-appears to have been a favorite one of M. Witte's, and was repeated again and again during the course of negotiations.

${ }^{17}$ No amount was stated. The attempt was merely made to establish the principle of remuneration.

${ }^{10}$ According to an Associated Press report, President Roosevelt's proposal, whatever it was, was based upon the principles of arbitration, but this was emphatically denied by the correspondent of the London Times, who maintained that the President's object in sending for Baron Rosen was simply to procure information. The President is said merely to have suggested, incidentally, as it were, that "it might be possible to form a commission of competent, disinterested men to examine the question of indemnity." See Cable to the London Times for August 2I, 1905. Dr. Dillon (see article in Contemporary Review, op. cit.) asserted, on the other hand, that President Roosevelt proposed the cession of the whole island of Sakhalin to Japan and the purchase by Russia of the northern half for a sum to be fixed by three arbitrators. Professor de Martens (see article in North American Review for November, 
were willing to waive Articles 9, Io and I I of their demands, and to sell the northern half of Sakhalin to Russia in consideration of a large sum of money. ${ }^{19}$ The Russians maintained, however, that this was simply the old proposal for indemnity in a new form, and remained firm in their refusal to pay a copeck of tribute. The utmost the Czar, in response to an appeal from President Roosevelt, ${ }^{20}$ would concede was the division of the island of Sakhalin between Japan and Russia.

After August 18 the conference almost ceased to meet, ${ }^{21}$ and an attempt was made to conduct negotiations between Tokio and St. Petersburg with President Roosevelt as intermediary. Having made several vain appeals to the Russian Czar, who remained firm (except for his willingness to cede the southern part of Sakhalin to Japan), the President turned to Tokio, ${ }^{22}$ where the influence of the "elder states-

1905), who erroneously refers to the President's action as an "intervention," says that he at first proposed that a commission composed of neutrals be selected to fix the amount of the sum that Russia should pay Japan. Their decision was, however, not to be binding upon the contending parties.

${ }^{19}$ The sum named was $\$ 600,000,000$. This Japanese proposal was, according to the London Times correspondent, erroneously attributed to President Roosevelt by the American Press; but Dr. Dillon insists that it was inspired by the President.

${ }^{20}$ According to Dr. Dillon, this appeal was made through a telegram which President Roosevelt asked M. Witte to forward to the Czar; according to W. T. Stead (see Am. Review of Reviews for October, I905), Ambassador Meyer is entitled to the credit of having persuaded the Czar to change his mind and agree to cede the southern half of Sakhalin.

${ }^{21}$ There were only two sessions of the conference between Friday, August 18, and Tuesday, August 29, viz., the brief sessions of August 23 and 26 , at which the Japanese proposal above referred to was made and rejected.

${ }^{2}$ Prior to this time the President held frequent interviews with 
men" and possibly that of Great Britain (which had just concluded an offensive and defensive alliance with Japan) finally prevailed with the Mikado in favor of peace.

It was generally believed that President Roosevelt had failed at Tokio as well as at St. Petersburg when the Portsmouth Peace Conference met for what was thought to be its last session on the morning of August 28. To the surprise and amazement of the Russians themselves, Baron Komura, acting on instructions from Tokio, gave the sanction of the Japanese envoys to the division of the island of Sakhalin between Japan and Russia and withdrew all demand for indemnity. Thus the only obstacles to an agreement had been removed and one of the greatest wars in history was virtually at an end.

At first sight it seemed to the Japanese and their friends ${ }^{23}$ that those who had conquered in warfare had been outwitted and outgeneraled in diplomacy. It was said that all the points of disagreement between the negotiators had gradually been reduced to that of indemnity, and that the Japanese had been made to appear before the world as though they were willing to wage war for money.

There is doubtless a certain amount of justification for this point of view, but it may be said, on the other hand, that Japan secured at Portsmouth all and even more than she had demanded from Russia prior to the outbreak of the war. She not only obtained the recognition of her paramount interests in Korea, a promise to evacuate Manchuria within eighteen months, a recognition of the principles of

Baron Kaneko, who was described in the newspapers as the "financial" or "unofficial" representative of the Japanese Government.

${ }^{23}$ For expressions of dissatisfaction with the treaty, see, e. g., Professors Reinsch and Seaman in the Outlook for September 16, rgo5. 
the territorial sovereignty of China and equal opportunity of all nations in Manchuria, and the transfer of the Liaotung Peninsula to herself; but she also obtained possession of the southern branch of the Chinese Eastern or TransManchurian railway from Port Arthur and Niu-Chwang to Kuan-chang-tsu (which runs through the richest of the three Manchurian provinces) and the cession of the southern half of the large island of Sakhalin, in addition to valuable rights of fishing on the Siberian coast.

By the Convention of November 17, $1905,{ }^{24}$ the independence of Korea was formally extinguished and the management of Korean foreign affairs was placed under the protection and control of Japan. The evacuation of Manchuria by Russia and Japan will, if executed in good faith by both parties, secure to the commerce and industry of all nations a neutral zone between Korea and China on one side and Siberia on the other, which should tend to prevent friction and preserve peace for many years. But, above all, the Russian Advance in the Far East-that great and growing danger which menaced the very life of Japan-was checked. ${ }^{25}$ From her citadel at Port Arthur, the Gibraltar of the Gulf of Pe-chi-li, Japan can now command the entrance to Peking and play a leading part in the reorganization of the Chinese Empire.

There was one factor in the situation at Portsmouth of which the public was ignorant at the time and whose importance in inducing peace it is even now impossible to esti-

${ }^{24}$ See, supra, note on p. 75.

${ }^{25}$ It is well to remember, however, that the Russian Advance in the Far East was merely checked, and that the power of Russia was not destroyed. She remains, commercially speaking, in possession of the two largest provinces of Manchuria, and her position there is infinitely stronger than it was before its occupation. 
mate. It was not until several weeks after the Treaty of Portsmouth had been signed that it became known that on August 12, 1905, during the progress of negotiations, an offensive and defensive alliance had been concluded between England and Japan. The text of this alliance, so important in the future history of international relations, is as follows:

Preamble.-The Governments of Great Britain and Japan, being desirous of replacing the agreement concluded between them on January $30,1902,{ }^{26}$ by fresh stipulations, have agreed upon the following articles, which have for their object:

(a) the consolidation and maintenance of general peace in the regions of eastern Asia and India;

(b) the preservation of the common interests of all Powers in China by insuring the independence and integrity of the Chinese Empire and the principle of equal opportunities for the commerce and industry of all nations in China ;

(c) the maintenance of the territorial rights of the High Contracting Parties in the regions of eastern Asia and of India, and the defense of their special interests in the said regions.

ARTICLE I. It is agreed that whenever, in the opinion of either Great Britain or Japan, any of the rights and interests referred to in the preamble of this Agreement are in jeopardy, the two Governments will communicate with one another fully and frankly, and consider in common the measures which should be taken to safeguard those menaced rights or interests.

ART. II. If, by reason of an unprovoked attack or aggressive action, wherever arising, on the part of any other Power or Powers, either Contracting Party should be involved in war in defense of its territorial rights or special interests mentioned in the preamble of this Agreement, the other Contracting Party will at once come to the assistance of its ally, and will conduct war in common, and make peace in mutual agreement with it.

ART. III. Japan possessing paramount political, military

${ }^{25}$ For the text of this alliance, see supra, pp. 26-27. 
and economic interests in Korea, Great Britain recognizes the right of Japan to take such measures of guidance, control and protection in Korea as she may deem proper and necessary to safeguard and advance those interests, provided always that such measures are not contrary to the principle of equal opportunities for the commerce and industry of all nations.

ART. IV. Great Britain having a special interest in all that concerns the security of the Indian frontier, Japan recognizes her right to take such measures in the proximity of that frontier as she may find necessary for safeguarding her Indian possessions.

ArT. V. The High Contracting Parties agree that neither of them will, without consulting the other, enter into separate arrangements with another Power to the prejudice of the objects described in the preamble of this Agreement.

ART. VI. As regards the present war between Japan and Russia, Great Britain will continue to maintain strict neutrality unless some other Power or Powers should join in hostilities against Japan, in which case Great Britain will come to the assistance of Japan, will conduct war in common, and will make peace in mutual agreement with Japan.

ART. VII. The conditions under which armed assistance shall be afforded by either Power to the other in the circumstances mentioned in the present Agreement, and the means by which such assistance is to be made available, will be arranged by the naval and military authorities of the Contracting Parties, who from time to time will consult one another fully and freely upon all questions of mutual interest.

ArT. VIII. The present Agreement shall, subject to the provisions of Article VI, come into effect immediately after the date of signature and remain in force for ten years from that date. In case neither of the High Contracting Parties shall have been notified twelve months before the expiration of the said ten years of the intention of terminating the Agreement, it shall remain binding until the expiration of one year from the day on which either of the High Contracting Parties shall have denounced it; but if, when the date fixed for its expiration ar- 
rives, either ally is actually engaged in war, the alliance, ipso facto, shall continue until peace is concluded. ${ }^{27}$

It will be seen that this treaty, the objects of which are clearly set forth in the preamble, provides for common action in case the interests of either Power in the Far East are threatened by "an unprovoked attack or aggressive action." These interests are of two sorts-general and special. The general interests are the maintenance of peace, the preservation of the independence and territorial integrity of the Chinese Empire, and the retention of the "open door" in China. The special interests are those of England in India and of Japan in Korea. These interests, whether general or special, have never been seriously threatened by any Power or Powers, except by Russia, and, in a lesser degree, by Germany and France. Considering the weakened condition of Russia as a result of war and revolution, it would seem that the Anglo-Japanese Alliance, especially if it receive the moral support of the Government and people of the United States, ought to insure peace and the status quo in the Far East for many years to come.

${ }^{27}$ For the text of this agreement, as also an explanatory dispatch from Lord Lansdowne to Sir Charles Hardinge, see London Times (weekly) for September 29, 1905, p. 6r3. Lord Lansdowne calls special attention to Articles II and III and lays stress upon the purely peaceful and defensive character of the agreement. The treaty, although signed on August I2, was not published before September 27, 1905. 



\section{INDEX}

Administrative entity of China, 246 and n., 332, 338.

Admiralty Court at St. Petersburg, upholds decision in cases of the Cheltenham, I73 n., and the Calchas, I78; reverses decision in case of the Arabia, 177; declares cotton contraband, 178 .

Agreements (see also Alliances, Conventions, and Treaties) :

Alexieff-Tsếng (1900), I8-19, 334.

Anglo-German (1900), 329.

Anglo-Russian (I899), 31, 328329.

Modus vivendi relating to Manchuria (1900), I9-20.

Russo-Chinese Bank (1896), I3I4, 335 .

Alabama, case of the, 77 n., 97, I08-I09 and n., II2-II3, 325. (See also Geneva Award.)

Aldebaren, the, fired upon, $218 \mathrm{n}$., 223 n., 238 n.

Alexandra, case of the, 104 and n.

Alexieff, Admiral, 55, 56 n., I 36 n., 260 n.; appointed Viceroy, 57; policy of, 57 ; advice to the Czar, $60 \mathrm{n}$.; order of, to treat war correspondents as spies, II -116 n., II9; his Manchurian proclamation, 25I-254; enlists convicts, 309 ; report of, 3 II n.; accuses Japanese of using lyddite shells, 316.

Alexieff-Tsêng Agreement, 334; terms of, I8-I9.

Allanton, case of the, 138, 171-172, $173 \mathrm{n}$.

Alliances :

Anglo-Japanese (1902), 26-29, 336-337.

Anglo-Japanese (1905), 339, 347, 357-359.

Russo-Chinese ( 1896 ), I2-13 n.

Ambulances, field, neutralized, 273.

American Civil War, questions arising during, I54 n., I75 n.,
I90, I98 and n., 210 n., 213 n., 262, 325.

Ancipitis usus, I60, 16r, n., 166, I69, 201.

Anglo-German Agreement (1900), 329.

Anglo-Japanese Alliance (I902), text of, 26-27; Lord Lansdowne on, 27-28; declaration regarding, 28-29; attitude of Russian Government toward, $29 \mathrm{n}$.; effect of, 336-337; sympathy of United States with, 339 .

Anglo-Japanese Alliance (I905), 347 ; objects of, 357,359 ; text of, 357-359; importance and results of, $356,359$.

Anglo-Russian Agreement (1899), 31, 328-329.

Anna, case of the, $262 \mathrm{n}$.

Arabia, case of the, 144, 165-166 n., I73, 176-177.

Arbitration, 98 n., 134; in Alabama case, $98 \mathrm{n}$.; by the North Sea Commission, 233 and $n$., 240-24I and $n . ;$ of the Waima incident, $242 \mathrm{n}$.; in the case of the General Armstrong, 262 n.; between England and Venezuela, 325; Hague Conference on, 347; President Roosevelt's proposals based on, 354-355 n.

Ardova, seizure of the, $142 \mathrm{n}$.

Argentine Republic, negotiations with, for the purchase of warships, 94 and $n$.

Asakawa, Dr., on causes of the "Russo-Japanese Conflict," 2-3, 9, I2-I3 n., I4 n., 44 and n., 46, 49, 51 .

Askold, the, interned at Shanghai, 205-206, 267.

Asylum, to ships of war, not to be abused, 203, 205; conditions of, 2 Io and n.; Russia accused of abusing, 26I.

Aurora, the, interned at Manila, 209-210. 
Austria-Hungary, 4r, 96, 210 n.; accepts Hay Note, $247 \mathrm{n}$.

Auxiliary Navy, German, steamers of, sold to Russia, 9I and n., Iro.

Balaskoff, General, charges Japanese with violation of rules of warfare, 305.

Balfour, Premier, I42 n., I44 n., I48 n., I97; suggests interning rescued Russian sailors, 76 ; justifies sale of merchant vessels to belligerents, 93 ; on necessity of adjudication by prize court, I45 $\mathrm{n}$.; on right of visit and search, I45 n., I49 and n.; on use of neutral ports by belligerents, 214-215 ; Southampton speech of, on North Sea Incident, 226-228; on rights of belligerent fleets on the high seas, 227-228; on International Commission of Inquiry, $233 \mathrm{n}$.

Balloons, those carrying despatches in, not spies, II6 n., I35 n., 279; Russia agrees to Hague Declaration prohibiting the dropping of explosives from, 27I, 317-318 and n.; used by Japanese at Port Arthur, 305.

Baltic Fleet, prolonged inactivity of, I38; voyage of, I88, 190-194, 202-217; attacks British fishing fleet, 2I7-218; consequent excitement in England, 2I8 and n., 220, 223-224; detention of, at Vigo, $225-226$ and $n$.; use of French ports and territorial waters by, I9I-93; supplied with coal by British and German vessels, 203; joined by Nebagatoff's squadron, I94; destroyed in Korean Straits, .194, 209, 347; voyage of, illustrates defects in law of neutrality, 198, 202, 214 .

Base of operations, 112, 203, 212, 214; use of Madagascar as a, 193; use of Che-Foo as, 26r n., $266-267$; use of Mia-Tao islands as, 259, 265.

Base of supplies, 212, 264; at Saigon, I93, I98 and $n$.

Battle-field, Japanese Regulations relative to clearing of, $291-294$.

Belgium, Russian purchase of transports in, 93; accepts Hay Note, 247 n.; neutralization of, 248.

Belligerent armed vessels (see Warships.)

Belligerents, rights and duties of, as affected by war, $62,67,85$, 272 ; duties of, in preventing abuse of wireless telegraphy, I 19, I22-125, I34, n., I35 n.; laying submarine mines, I $30-132$ and n., I34 n., I35 n.; right of visit and search by, I48-156, I 77 n. ; rights of, in sinking neutral vessels, ${ }_{5} 6$ and $n$. ; rights of, on high seas, 227-228, 242-245; rights and duties of, according to Russian "Instructions," 273276.

Benckendorff, Count, Russian ambassador at London, 220-22I, 225 and n., 226, $338 \mathrm{n}$.

Bismarck, Prince, 84 n., I 6 n.

Blockade, of Russian fleet at Port Arthur, 138; law of, I72 n., I8I, 264 ; Russian rules of warfare relating to, 270 .

Board of Trade, British inquiry of, at Hull, 223 and n.

Boer War, questions relating to, I 54, I75, I79 n., 295 n., 299 n., 301 n., 3IO n., 3I5 n., 333 .

Bombardment (on land) of towns, etc., not occupied by the enemy prohibited, 274 ; notification necessary, 274; Hague Regulations on, $307 \mathrm{n}$.

Bombardment (naval), question of, unsettled, 306 and 307 n.; Hague Regulations on, 3I I-3I2 and $\mathrm{n}$.; opinions of publicists on, 3I2, 3I3-3I5 n.; recent practice in respect to, $313-316$, and 316 $\mathrm{n}$.; of Vladivostok and Gensan, 3 II and n., 316.

Bosporus, the, I38, I4I, I48, I5I.

Boxer uprising, I6, 256, 332, $333 \mathrm{n}$. Brazil, 213 n.

Brussels Code, on war correspondents, 120 and n.; compared with Russian "Instructions," 272 n.; the basis of the Hague Regulations, $295 \mathrm{n}$.; on prisoners of war, $278 \mathrm{n}$.; on flag of truce, $279 \mathrm{n}$.; prohibitions of, $301 \mathrm{n}$. 
Buena Ventura, case of the, $297 \mathrm{n}$. Bülow, German Chancellor, 92, IIO, II I n., $334 \mathrm{n}$.

Bureau of Information for prisoners of war, Russia fails to provide, 278; Art. I4 of Hague Regulations on, 288-289; Japan issues Imperial Ordinance relating to, 289-290; duties of, 28829I ; established by Japan, 284, 319-320; established by Russia, 322.

Cables, submarine, proposal to connect Japan with Philippine Islands by means of, 78-79; the law of, 122-123 and n., 266.

Calchas, case of the, 144, 173, 176I78, $177 \mathrm{n}$.

Capture, right of, 148,149 and $n$.

Caroline, case of the, $96,262$.

Cass, Secretary, lays down rule for neutrals, II2-II3.

Cassini Convention, terms of, roI2.

Cassini, Count, 34 n., 79, I I 5-116, $119,260,268$; on rights of belligerent fleet on the high seas, 242-243; reply to, 243-244; on evacuation of Manchuria, 256.

Cheltenham, case of the, I38, I73 n.

Chesapeake, case of the, $262 \mathrm{n}$.

Che-Foo, II9, 259, 303, 349; wireless telegraph station at, I22 n., 124 n., 259, 266-267; the Ryeshitelni at, 260 ; use of, by Russia as a base, 26I $\mathrm{n}$.

Chemulpo, 44, 47, 51, 66, 70, 7I, 75, I75 n.

Chile, negotiations with, for purchase of warships, 94 and n.; sells such vessels during ChinoJapanese War, $97 \mathrm{n}$.

China, Japan's interest in, $2,26,36$, 325-340; threatened dismemberment of, 2, 327, 334; open door in, $2,24,25,26,28,35,54,56$, $328-338,356-357,359$; independence and territorial integrity of, 2, 26, 28, 29 n., 52, 53-54, 56, 58, $60,328,332,334,336,338$ and $n$., 357,359 ; cedes Liao-tung $\mathrm{Pe}-$ ninsula, 7; concludes Cassini Convention, IO-12; agrees to fortify Port Arthur and Talienwan, I2; concludes agreement with the Russo-Chinese Bank, I3-14; leases Kiao-chau to Germany, 15, 327; leases Port Arthur and Talien-wan to Russia, I5, 256 n., 327; leases Wei-haiwei to Great Britain, I5, 328; leases Kwang-chau Bay to France, 16, 328; refuses to sign Lamsdorff-Yang-yu Convention, 22 ; agrees to protect railways and Russians in Manchuria, 24; refuses to sign agreement with Russia regarding Russo-Chinese Bank, 26; makes counter proposals, 26, 29; interests of Great Britain in, 26, 325, 340; agrees to observe agreement with Russo-Chinese Bank, 29; enters into convention with Russia for evacuation of Manchuria, 29-32, 337; rejects seven Russian demands, 34-36 n., 337; refuses six fresh Russian demands, 36 n., 57 ; relations with Korea, 37 ff. (see Korea) ; interest of United States in, 79, 325-340; AngloRussian Agreement respecting, 328-329; Anglo-German Agreement respecting, 329; Hay's Circular Note of 1899 respecting interests in, 329-33I; Mr. Choate on interests in, 33I; Hay second circular note respecting conditions in, 332; representations of Japan, Great Britain, and United States to, 334-335; appeals to Powers, 334-335; Secretary Hay protests against proposed agreement with, relating to RussoChinese Bank, 335; concludes commercial treaty with United States, 338; concludes commercial treaty with Japan, $338 \mathrm{n}$.; gives notice that she will not recognize arrangements made regarding Manchuria, $349 \mathrm{n}$.; reorganization of, by Japan, 356 .

China, questions relating to neutrality of: Limits stay of belligerent warships in neutral port to twenty-four hours, $88 \mathrm{n}$., 2I3 n.; demolishes wireless telegraphy station at Che-Foo, 122 
n. ; vacillating conduct of, in the case of the Mandjur, 188-189, 267 ; of the Czarevitch and Grosovoi, 205-206, 267; incapable of perfectly fulfilling her neutral obligations, 216, 267-268; guaranteed by Hay Note of February IO, I904, I88 n., 246-247, 338; meaning of term neutrality as applied to, 248-249; anomalous position of, in respect to Manchuria, 249-251 ; danger of international complications because of threatened violations of, 25I, 260; Admiral Alexieff's proclamation not a violation of, 252-254; Russian complaints of violations of, 254259; dispatch of Chinese troops to Manchurian frontier not a violation of, 254; presence in Chinese army of a few Japanese military instructors not a violation of, 255 ; landing of Japanese troops in region west of the Liao River not a violation of, 257-258; Russia specifies five distinct breaches of, 258-259; Japan alleges numerous violations of, by Russia, 259, 26I and n.; China alleges violations of, by Russia, 259-260, 265-267; alleged violations of, by China, 264-265; trivial nature of most of these allegations, 260, 264, 267; the seizure of the Ryeshitelni a gross violation of, 260-264; replies to Russian charges of violation of, $264-265$; alleged violation of, in region west of the Liao River, 257-258, 26 I n., 265266; lax enforcement of, in case of wireless telegraphy station at Che-Foo, I22 n., 259, 26I n., 266-267; reasonable success in maintenance of, 267-268.

Chinese clothing, use of, by Russian troops, 307-308.

Chinese Eastern Railway, I3, I5, 57-58, 351, 356.

Ching, Prince, 23, 29.

Chino-Japanese War, questions relating to, $6,43,65$ n., 97 n., 304 n., 327.
Choate, Mr., American ambassador at Court of St. James, 33I.

Chuncheses, the, 32, 252, 254-255, 259, 264.

Cincinnati, case of the, I77 n.

Circular Notes to the Powers:

Hay Note (Sept. 6, 1899), 329330.

Second Hay Note (July 3, I900), 332.

Russian Note (July, 13, 1900), I $7 \mathrm{n}$.

Russian Note (Aug. 28, 1900), I7.

Hay Note (Feb. Io, I904), 246247, 338 .

Russian Note (Feb. 22, I904), $67,70-7 \mathrm{I}$.

Russian Note (April I5, I904), II 5-II6.

Hay Note (June I0, 1904), I68I70.

Russian Note (Jan., 1905), 258259.

Coal, as contraband, 138 , I60, I6 1 n., 162 n., 164, 166,168 and n., I69, I70, I71, 180, 201, 203.

Coal, the supply of, to belligerent vessels in neutral ports and waters, 88-89 and n., I90-I98; importance of, in naval warfare, 89 n., 200-203; used in stopping neutral vessels, 189 ; the Baltic Fleet supplied with, 190-198, 203; supply of, during American Civil War, 190, 198 and n.; divergence in practice in respect to the supply of, I98-I99 and n.; advanced ground taken by Great Britain in respect to, I99; instructions by Egyptian Government in respect to, $199-200$; Proclamation of Governor of Malta forbidding, 200; present regulations respecting, insuffcient to preserve neutrality, 202203; opinions of authorities on, 2I I-2I2 n.

Commerce, neutral rights of, I62 n., I65 n., I67, I70, I80-I8I, 226 and n., 242-245, 269-270; Russian rules of warfare relating to, 269-27I.

Commercen, case of the, I72 n. 
Conger, Mr., American Minister to China, 23, I27 n., $254 \mathrm{n}$.

Contraband of war, arms and ammunition as, 107, 160, I6I n., 163 and n., r68, r80; coal as, 138, 160, 161 n., 162 n., 164, 166, 168 and n., I69, I70-I7I, I80, 201, 203; cotton as, 165, I68 n., I70, 176 and n., 178, 180; food stuffs as, I60-16r n., I64-166 n., 167-168 n., 170, 175-176, I79 and n., I80, I82; fuel as, I64, I65 n., I68-170; horses as, I60, I62 n., 168, 169, 183; machinery as, 160, 164,166 n., 176 and n.; money as, $85,162 \mathrm{n}$.; railway material, $164,167,173$ n., I74, I75 and n., I76, 179-180; rice as, 164, I66, I69; submarines classed as, 95, II I ; telegraphic material as, I60, 164, 166-167, 179-180; telephonic material as, I60, I64, I79-180; timber as, 160, 162 n., I73 n., I76; war vessels as, I03-104; wireless telegraphy apparatus as, 123 and $n$.

Contraband of war, cases on, arising during the war:

The Allanton, 138, I7I-1 72.

The Arabia, 144, I65-166 n., 173, I76-177.

The Calchas, 144, 173, 176-178.

The Cheltenham, 138, I73 n.

The Fulton, 95, II 2 n.

The Ikhona, $143,147 \mathrm{n}$.

The Knight Commander, I44147, 173-174 and $\mathrm{n}$.

The Malacca, I39, I40-14I, I5I152.

The Princess Marie, I43 n., I47 n.

The Protector, 94-96, I I2-I I4.

The St. Kilda, I43 n., I47 n.

Contraband of war, division of, into absolute and conditional contraband, I6o; latter opposed by Continental publicists, 162I63 n.; doctrine of intent as applied to, I07 n.; importation of, into Dalny from Chinese ports, 259; Japan's list of, 16016I ; questions relating to, I60 I68; right of visit and search for, 136, 148-156; Russia wholly ignores Grotian distinction be- tween absolute and conditional contraband, 163; British and American protests against Russian .view, $145-146$ and n., I67 and $n ., 178,179-182$; Lord Lansdowne criticizes, 178-179; Secretary Hay on, 179-182; Russian view modified, I82-183; Russia's list of, $163-165$; interpretation of, 165-166 n.; Russian rules of warfare relating to, 269-270; sinking of vessels for carrying, I 43 n., I44-I 47 ; smuggling of, by Russians from China into Manchuria, 260; trade in, 107, I38; legality of trade in, $183-187,264$; views of authorities and modern practice as to, $185-187$ and notes.

Continuous voyage, doctrine of, 172 n., I75 n.

Conventions (see also Treaties, Agrecments, and Alliances):

Convention of Tientsin (I885), $4 \mathrm{I}$.

Russo-Turkish Convention ( $189 \mathrm{I}), 148 \mathrm{n}$.

Cassini Convention ( 1896 ), terms of, ro-i2.

Convention of Peking (I895), 8.

Conventions of Hague Conference (1899), (see Hague Conference).

Lamsdorff-Yang-yu (I 90 I), terms of, 2I-22.

Proposed Convention of Evacuation (I9OI), 23-24.

Convention for Evacuation of Manchuria (I902), terms of, 29-32, 337.

Convention between Japan and Korea (1905), 75 n., 356.

Contributions to Red Cross Society, legality of, $80-8 \mathrm{r}$; communication from Secretary Hay to $\mathrm{Mr}$. Takahira regarding, $8 \mathrm{I}$; no sound objections to, 84 ; the right to make gifts for warlike purpose doubtful, 84 .

Contributions for military purposes permissible, 253; conditions under which they may be imposed, 275 and n.; whether permissible in case of bombardment by naval force, 3r4-3r5 $\mathrm{n}$. 
Convicts, enlistment of, by Russia, 309-3II.

Convoy, neutral and enemy, I50$15 \mathrm{I}$ and $\mathrm{n}$.

Correspondents, newspaper, rights of, in war, II5-125; Russia threatens to treat, as spies, II5II7 and n.; status of, I19-12I and $\mathrm{n}$.; entitled to privileges of prisoners of war, I20-I2I ; may be excluded from belligerent territory, 122; harder to control since the invention of wireless telegraphy, I22.

Cossacks, the accusations against, 308.

Crimean War, questions relating to, 5, 175 n., 260 n., 296, $352 \mathrm{n}$.

Czar, the (see also Russia), issues Manifesto of February 10, 67; orders release of colliers seized in the Red Sea, 138; insists upon release of Malacca, I4I; orders Admiral Rojestvensky to leave Kamranh Bay, 194; orders disarmament of the Askold and Grosvoi, 206; expresses regret and promises reparation in North Sea Incident, 219-220, 226; accepts principle of International Commission of Inquiry, 225 , and $n$. ; given credit for solution of North Sea Incident, 228 n.; ratifies "Instructions" to the Russian army, 27I-272; agrees to divide Sakhalin, 354 and $n$.

Czarevitch, visit of, to the Far East, 6.

Czarevitch, the, interned at Tsingtau, 204.

Dalny (see Talien-wan).

Dardanelles, the, I38, I4I, I48, I5I.

"Days of Grace" allowed to enemy merchantmen in belligerent ports at outbreak of war, Russian rules relating to, 269 , 295296; Japanese rules relating to, 28I-282, 295-296; recent practice respecting, 296-297 and $n$.

Dead, the, Russian Regulations relative to, 29I-294; customary to grant truce for burial of, 304 and n.; mutilation of, 308-309 and $\mathrm{n}$.
Declarations :

Declaration of St. Petersburg (I868), 270, 27I n., 3I8 n.

Declarations of Hague Conference (1899), 271 and n., 317$3 \mathrm{I} 8$ and $\mathrm{n}$.

Russo-French (I902), text of, 28-29.

Russian Declaration (I904), threatening to treat war correspondents as spies, II5-II7.

Declaration of St. Petersburg (1904), 231-234 and notes, 24I and $n$.

Declaration (Chinese) of Neutrality (I905), 254 n., 257, 265.

Declaration of war no longer necessary, $62 \mathrm{ff}$; views of older authorities as to, 62 n.; views of modern authorities on, 62-64 and notes; practice in seventeenth century as to, $64 \mathrm{n}$.; in eighteenth century, 63 n.; recent practice and historical examples, 64-65 and notes; does not exclude surprise or treachery, 65 ; ultimatum a conditional declaration, 66; charges of Japan against Russia regarding, examined, $66 \mathrm{ff}$.

Deerhound, case of the, $77 \mathrm{n}$.

Demurrage, payment of, by Russia, 137 and $n$.

Denmark, limits stay of belligerent warships in neutral ports to twenty-four hours and supply of coal in neutral waters, 88-89 n.; accepts Hay Note, $247 \mathrm{n}$.

Destination, belligerent, essential in case of contraband, $162 \mathrm{n}$., I68, 169, I75 n., I80.

Detention of neutral merchantmen, I36-137.

Diana, the, interned at Saigon, I96, 204.

Diplomacy, European, real character of, 9 ; modern methods of, 70 ; Treaty of Portsmouth interesting to students of, $346-347$; Japanese diplomacy at Portsmouth, 355-356.

Diplomatic relations $b$ etween Japan and Russia severed, 6I, 68-70; effect of breach of, 66. Disarmament of belligerent war- 
ships in neutral ports (see Internment).

Dmitri Donskoi, the, violates neutrality of Egypt, I89; fired upon, during North Sea Incident, 238 n.

Dogger Bank, 217, 219, 223 n.

Double or ambiguous sovereignty, law of, 249-25I; examples of, 250 n.; Manchuria an example of, 249-250, 253; analogous to military occupation, 253.

Due diligence, 98 n., I02; rule of, 97-98; difference of opinion regarding meaning of, 99 n., ro 4 , I06; criticism of American definition of, I04-I05 and n.; proof of lack of, necessary, II $4 \mathrm{n}$.

Dumdum bullets, Declaration of Hague Conference prohibiting use of, 27I, 3I8 and n.; Russia accused of using, 317 ; controversy respecting use of, $3 \mathrm{I} 8 \mathrm{n}$.

Egypt, questions relating to neutrality of, I38, I89, I 92 and n., 199-200; an example of double sovereignty, $250 \mathrm{n}$.

Elba, the, rescues Russian sailors at Chemulpo, 75 and $n$.

England (see Great Britain).

Enemy State, moveables of, may be taken, 273; peaceful inhabitants of, not to be injured, 280 .

Enlistment, legality of, $82-83$; forbidden by President Roosevelt's Proclamation of Neutrality, 87 ; Chinese Government on, 264; of convicts by Russia, 309-3Ir.

Equal opportunity, principle of, 2, $26,28,52,53$.

Ettrickdale, seizure of the, $137 \mathrm{n}$.

Evacuation (see Conventions and Manchuria).

Evarts, Secretary, classes torpedo craft as contraband, iII.

Expedition, hostile, duty of neutral to prevent, IOI; a modern warship an approximation of, II2.

Explosives dropped from balloons, declaration relating to use of, 27I, 3I7-3I8 and n.; Japanese accused of using, to produce poisonous gases, $3 \mathrm{I} 6$.
Far East, interests of Russia in, $2-3,28$; visit of Czarevitch to, 6 ; interests of France in, 28; voyage of Baltic Fleet to, I90, I98, 217; coöperation of England, Japan, and United States in, $325,333-340$; interests of United States in, 327, 331, 339340 ; interests of Great Britain in, 33I, 339-340, 359; Japan demands limitation of Russian naval forces in, 35I ; Russian advance in, checked, 356 and $n$.

Far Eastern Question, the, as affecting relations of England and United States, 325-34I ; as affected by Anglo-Japanese Alliance of January 30, 1902, 336.

Felicity, case of the, 156 .

Fishery, rights of, granted by Russia to Japan, $343,35 \mathrm{r}, 356$.

Flags of truce, unlawful use of, 274, 301 and n., 303, 304 n., 309; rights of bearer of, $278-279,28 \mathrm{r}$, 304 ; ignored, 303.

Fleets, belligerent, rights of, in neutral ports and waters (see also Baltic Fleet), 200, 214; rights of on high seas, 227-228, 242-245.

Fooping, case of the, 259.

Foreign Enlistment Acts of Great Britain, 82, 97 n., 99-100 and n., I08, I I o n., 190, 204.

Florida, case of the, $262 \mathrm{n}$.

Formosa, seizure of the, $\mathrm{r} 42 \mathrm{n}$.

Foxton Hall, the, Russia grants compensation for losses sustained by, $\mathrm{r} 37 \mathrm{n}$.

Fram, case of the, $186 \mathrm{n}$.

France, intervenes to secure retrocession of Liao-tung Peninsula, 7; leases Kwang-chau Bay from China, $x 6,328$; declaration of, rega rding Anglo-Japanese Agreement, 28-29; interests of, in the Far East, 28; fails in performance of neutral duties, 78 n., 90, I90-I98; advises release of the Malacca, I4I; makes rice contraband, I6I n.; declares coal not contraband, I69; declaration of, in respect to trade in arms and ammunition, I86 n.; exchanges friendly communica- 
tions with Japan, I89; "Instructions" of, 189-190, 194, I99, 202; permits Russian vessels to take full supply of coal at Jibutil, 190; permits Baltic Fleet to coal at French ports, I9I-I92; to coal and winter at Nossi-Be, I92; to receive supplies from Saigon, I93; to use coast and waters of Indo-China, I94; enters general denial of Japanese charges, I95; lays down four general propositions, I95-I96; declares Japanese remonstrances unjustifiable for four reasons, 196-197; draws up five "Conclusions," I97-198; accepts Hay Note, 247 n.; "Regulations" of, for prisoners of war, $278 \mathrm{n}$.; allows days of grace at beginning of Crimean War and in 1870, 296; orders Germans to leave Paris in 1870 , 299 n.; transmits Russian protest against alleged infraction of laws of war by Japan, 306; criticised for employing Turcos in I870, 310 n.; violates territorial integrity of China, 328; replies to Hay Circular Note of September 6, I899, 338; relations of, with Russia, 334 n.; policy of, in the Orient, 339.

Franco-German War, questions arising during, $204 \mathrm{n}$., 3I5 n.

Frankly, seizure of the, I37 n.

Fulton, case of the, 95, II2 n.

$F u$ Ping, the, fired upon, $136 \mathrm{n}$.

Fürst Bismarck, sale of the, to Russia, 91.

Geneva Award, 83, 97, 98 n., 104, II3 (see also Alabama Case).

Geneva Convention, Russia agrees to observe, 270, 27I and n. ; compared with Russian "Instructions," 272-273 n.; 276 n. ; Russia accuses Japan of violating, 302, 305.

General Armstrong, case of the, 262-263 n.

Gensan, bombardment of, 3II, 3I6. Germany, intervenes to secure retrocession of Liao-tung Peninsula, 7 ; secures lease of Kiaochau, I5, 327; protests against the Alexieff-Tsêng Agreement, 19; fails in the performance of neutral duties, 78 n., 90, 9I-93; IIO-III; fails to prevent sale to Russia of vessels belonging to Auxiliary Navy, 91 and n., IIO; fails to prevent exportation of torpedo boats overland to Russia, $9 \mathrm{r}-92$; orders for torpedo craft placed in, 96 ; protests against confiscation of mails of Prinz Heinrich, 139-140; renewed excitement in, caused by subsequent seizures, 142 ; correct in claiming that Russia had no right to remove mail bags, I55I56; remonstrates against export of coal to France, I6I n.; permits use of its auxiliary cruisers to furnish coal to Baltic Fleet, 203; position of, in the matter of repairs of belligerent warships in neutral ports, $204 \mathrm{n}$.; enforces twenty-four hour rule, 204, 2 I3 n.; destitute Japanese transported from Russia to, 298 and n.; suggests Hay Note, 247, 338 ; accepts Hay Note, 247 n.; guilty of violation of laws of warfare during Franco-Prussian War, 3I5 n.; violates territorial integrity of China, 328; enters into Agreement with England, 329 ; replies to Hay Circular Note of September 6, I899, 330; indifference of, to fate of Manchuria, 334 n.; makes representation to China, 334-335 n.; policy of, in the Orient, 339; supports President Roosevelt in representations to Czar, $348 \mathrm{n}$.

Gifts or subscriptions to Red Cross Society not illegal, 80-8I ; subscriptions to funds raised in behalf of Greek revolutionists held illegal, 86.

Good offices, Hague Conference on, 347 .

Governor of Malta, Proclamation of, forbidding coal to belligerent fleets or warships, 200, 202.

Goyo Maru, the, justifiable sinking of, by Russians, 300 .

Great Britain, advises Japan to recede the Liao-tung Peninsula, 8; 
leases Wei-hai-wei from China, I5, 327; protests against the Alexieff-Tsêng Agreement, I9, 334 ; protests against the Lamsdorff-Yang-yu convention, 22, 335; protests against Russian demands on China regarding Russo-Chinese Bank, 24, 26; interests of, in China, 26, 331, 339340,359 ; enters into defensive alliance with Japan, 26-29, 336337 ; protests against Russia's seven new demands, 36,337 ; seizes Port Hamilton, 42 ; evacuates the island, 43 ; sends seven British men-of-war to Chemulpo, 47; instigates China to refuse six fresh Russian demands, 57 ; at first insists upon taking rescued Russian sailors into British territory, 76 ; fails to perform its neutral duties in the case of the Deerhound, 77 n.; refuses request of submarine cable during Spanish-American War, 79; observes neutral duties during war, 89; purchase in, by Russia, of vessels for use as transports, 93; battleships ordered in, by Japan, 93 ; fails to prevent delivery of the Caroline to Russia, 96; agrees to abide by rules of Treaty of Washington, $98 \mathrm{n}$.; fails to use due diligence in the case of the Alabama, II3; Russian note to, threatening to treat war correspondents as spies, I 6 n.; receives assurances from Russia in reply to note, II $7 \mathrm{n}$.; storm of indignation in, because of seizure of Malacca, I39-140; protests against Russian violation of neutral rights, I39-I42; demands release of Malacca, I40; instructs Admiral Domville to patrol the Red Sea, I40; claims Malacca was carrying government stores, I40-I4I ; protests against visit and search by Russian Volunteer Navy, I4I and $n$.; excitement in, caused by subsequent seizures, 142 and n.; conveys orders of Russian Government to Russian warships, 142 n., I43 n.; renewed excitement in, because of sinking of Knight Commander, 142-144; protests against the sinking of Knight Commander, 144-145; occasional protest of, against passage of Straits by Russian Volunteer Navy, I 48 n.; the great champion of belligerent rights on high seas, 149 ; practice of, in respect to convoy, I50-I5I n.; practice of, in respect to destruction of prizes, $158 \mathrm{n}$.; protests against Russia's inclusion of food stuffs as contraband, I69; protests against Russian view of contraband and sinking of neutral merchantmen, I78, 339; position of, in respect to food stuffs as contraband during the Boer War, r79 n.; makes further representations to Russia as to coal and cotton, I83; enforces twenty-four hour rule and limits supply of coal to Russian warships, I90; takes advanced ground in respect to supply of coal to belligerent warships, 199; issues instructions to Colonial Governors forbidding coal to belligerent fleets and warships, 200 and n.; regards coal as ancipitis usus, 2or ; permits subjects to furnish coal, 201, 203; forbids access of belligerent warships to ports of the Bahama Islands during the American Civil War, zro n.; introduces twenty-four hour rule and limitation of coal-supply into international practice, $213 \mathrm{n}$.; enforces twenty-four hour rule during the Spanish-American War, $213 \mathrm{n}$.; anger and excitement in, caused by North Sea Incident, 218 and n., 220, 223$224,226 \mathrm{n}$.; fleets of, ordered to meet at Gibraltar, 220-22I ; demands of, upon Russia, 224; suggests International Commission of Inquiry, 224-225; negotiations of, with Russia respecting the scope and organization of North Sea Commission, 22823I; signs Declaration of St. 
Petersburg, 23I ; "Conclusions" of, 235; accepts Hay Note, 247 n.; conduct of, during Boer War, 295 n., 301 n., 310, 318 n.; allows six weeks of grace at the beginning of Crimean War, 296; opposes prohibition of bombardment by naval force, 3II n.; refuses to sign the three Declarations of the Hague Conference, $3 \mathrm{I} 8 \mathrm{n}$.; decides to stop manufacture of dumdum bullets, 3I8 n.; relations of, with the United States as affected by the Far Eastern Question, 325-34I ; friendship with United States greatly strengthened by coöperation in Far East, 325, 333-340; changed attitude of, toward United States during recent years, 325-326; sympathy of, with United States during Spanish-American War, 326; fails to enter a formal protest against lease of Port Arthur and Kiaochau, 327; fails to secure opening of Port Arthur, 327 n.; violates territorial integrity of China, 328; enters into Agreement of April 28, 1899 with Russia, 328-329; enters into Agreement of October 16, 1900, with Germany, 329; replies to Hay Circular Note of September 6, I899, 330 n.; Mr. Choate on policy of, in China, 331 ; interests of, and United States in the Orient identical, 33I, $338 \mathrm{n}$., 339-340; supported by United States and Japan in China, 333340 ; concludes offensive and defensive alliance with Japan, 355 , 357 ; recognizes paramount interests of Japan in Korea, 358359.

Groderkoff, General, on conquest of Manchuria, I6-17.

Grosovoi, case of the, interned at Shanghai, 206, 267.

Hague Conference (1899), Conventions of, Russia agrees to observe, 270-271 and n.; Declarations of, $27 I$ and n., 3I -318 and $\mathrm{n}$.; on International Commis- sions of Inquiry, 224-225, 231 and n.; 232, 240; expresses a wish for a Conference to revise Geneva Convention, 276 n.; Japan and Russia both signatories of, 295; expresses a wish that naval bombardment be considered at a future Conference, 3II-3I2 n.; on cases not included in the "Regulations," 312; controversy in as to use of dumdum bullets, $318 \mathrm{n}$.; on mediation, 347 .

Hague Conference, Regulations of, on carrying dispatches in balloons, II $6 \mathrm{n.}$; on war correspondents, 121; definition of spy, I2I and n.; do not prohibit use of submarines, I30 n.; provide for interment of belligerent troops on neutral soil, 76, 21 I n.; Russia agrees to observe, $270-27 \mathrm{I}$ and $n$.; question as to the binding character of, 27I-272 n.; compared with the Russian "Instructions," 272 n., 275 n., 278 n., 279 n., 285 n., 286 n., 287 n.; provide for Bureau of Information for prisoners, 278, 319; based upon Rules of Brussels Conference, 295 n.; ignored during Boer War, 295 n.; prohibitions of, 301 and n.; Russia accuses Japan of violating, 302, 305 ; relate merely to land warfare, 306-307 and n., 3II; on sieges and bombardments, 307 n.; leave question of naval bombardment unsettled, $307 \mathrm{n}$.; Japan accuses Russia of violating, 307; on militia and volunteer corps, 306-307; on bombardment of undefended towns, 3II3 I $2 \mathrm{n}$.

Hague Conference, questions for consideration at the coming Conference, I34, I55, 203, 245.

Hague Tribunal, questions for reference to, I34, 155.

Haimun, the, sends dispatches by means of wireless telegraphy, II 7 -I 19 and $n$.

Hamilton, on right of neutrals to trade in contraband, 186. 
Hansa, the, fired upon by the Japanese, $136 \mathrm{n}$.

Hardinge, Sir Charles, British Ambassador at St. Petersburg, I43 n., I45 n., I82, I83, 219, 222, and n., 230, $23 \mathrm{I}$.

Hatsuse, the, blown up by a submarine mine, I26, I29 n., I32 n.

Hay note of February 10, 1904, text of, 246-247; acceptance of, by the Powers and China, 246; conditional acceptance of, by Russia and Japan, 247-248; meaning of term "administrative entity" as used in, 246 n.; meaning of "neutrality" as used in, 248-249; Manchuria exempted from application of, 246 n., 249, 253, 258 ; tended to prevent serious violation of Chinese Neutrality, 268 ; in accordance with precedents, 338.

Hay, Secretary, protests against Russian demands on China, 24; denies that United States was considering application for submarine cable, 79; communication of, to Mr. Takahira, 8I ; on the ambiguity of Russian phraseology in his Note of August 30, 1904, 165-166 n., I79; Circular of, on Russian list of contraband, 168-170; requests investigation in case of Cincinnati, I77 n.; protests against Russian view of contraband in case of Arabia, 179-183; on nature of contraband, I80-I8I; on Russian doctrine of contraband, I8I ; proclaims neutrality and administrative entity of China, $246-247,338$; calls attention of China to Russian charges of violation of neutrality, 264 ; suggests Conference of the Powers, 268; issues Circular Note of Sept. 6, I899, 329-33I ; announces consent of each nation, $33 \mathrm{I}$; issues second Circular Note of July 3, 1900, 332; protests against agreement relating to Russo-Chinese Bank, 335336.

Hayashi, Mr., Japanese representative at Seot1, $48 \mathrm{ff}$., 5I, $75 \mathrm{n}$.
Hei-lung-chang, province of, 30 , 36.

Hideyoshi, invasion of Korea, 39. Hipsang, the, torpedoed by Russians, 143 n., 26 I $\mathrm{n}$.

Hitachi Maru, the, justifiable sinking of, by Russians, 300 .

Holland, purchase of transports in, 93 .

Holland, Professor, on submarine mines, $129 \mathrm{n}$.; on destruction of prizes, $157 \mathrm{n}$.; on language of British Neutrality Proclamation, I85 n.; on vagueness of law governing supply of coal to belligerent armed vessels, 203; on belligerent and neutral rights on the high seas, 244 ; on the binding character of the Hague Regulations, 272 n.; on bombardment by a naval force, 314$315 \mathrm{n}$.

Hospitals, military, neutralized, 273.

Hospitals, Red Cross, fired upon, 305-306 and n., $309 \mathrm{n}$.

Hull, Coroner's inquest at, 233; Board of Trade inquiry at, 233 and $n$.

Ikhona, sinking of the, I43 n., $147 \mathrm{n}$.

Imima, case of the, 172 .

Imperial Order of Feb. 28, I904, issued by Russia, 269-27I ; of Feb. 9, 1905, issued by Japan, $28 \mathrm{I}-282$

India, British interests in, 358359.

Indemnity, question of, 346, 35I, 352-355.

Indo-China, 190, 193-I97.

Inhabitants of enemy country, conditions under which they may be considered as belligerents, 272; life and property of, to be respected, 273 ; entitled to notice in case of bombardment, 274 ; duty of, to give succor to sick and wounded, 276; not to be injured, if peaceable, 280. (See also Non-combatants.)

Intent. American doctrine of, as applied to gifts and voluntary subscriptions, 86 ; as applied to 
warships, 87; as applied to First Rule of Treaty of Washington, $98 \mathrm{n}$. ; serious objection to, 99 n.; criticism of, I02-I03, 109 n.; complexity of, I03; difficult to distinguish between belligerent and commercial intent, 102-103, 107 n., 109 and n.; argument of Bernard on, $108-109$ and $n$.; as applied to contraband, $162 \mathrm{n}$.

Institute of International Law, adopts principles incorporated in the First Rule of the Treaty of Washington, 99; on war correspondents, I2O-I2I; seeks to obtain extension of three-mile limit, I33 n.; rules of, on wireless telegraphy and submarine mines, I $35 \mathrm{n}$.; on destruction of prizes, I $58 \mathrm{n}$.; attempts to abolish relative contraband, I63-I64 n.; sanctions doctrine of continuous voyage, $175 \mathrm{n}$.; on prisoners of war, $278 \mathrm{n}$.; on flag of truce, $279 \mathrm{n}$.; on bombardment by a naval force, 3I4 $\mathrm{n}$.

Instructions for the Government of the Armies of United States, on war correspondents, 120-12I and $\mathrm{n}$.; on prisoners of war, 278 n.; on flag of truce, $279 \mathrm{n}$.

"Instructions" to Russian Army, 272-28I ; compared with the Hague Regulations, 272 n., 275 n., 278 n., 279 n., 285 n., 286 n., 287 n.; compared with Geneva Convention, $272-273$ n., 276 n.

International Agreements, signed by Russia, 270-27I.

International Commissions of Inquiry, 224, 225, $23 \mathrm{I}$ and n., 232, 240-24I and n. (See also North Sea Commission.)

International ethics, justice of war a question of, 67 .

International morality, new standards of, set up by Japan, 319, 321,323 .

International Law, questions in: Effect of outbreak of war, 62; declaration of war, whether necessary, 62-66; effect of breach of diplomatic relations, 66 ; effect of ultimatum, 66 ; justice or injustice of war, 67 , and
67-68 11.; right of an independent state to remain neutral, 7 I and n.; conditions under which a treaty made under duress is nuil and void, 73-75; force and intimidation permitted means of obtaining redress for wrongs in, 73-74; proper treatment of sailors rescued by neutral vessels, 75-77 and n.; legality or propriety of neutrals permitting laying of submarine cables, 79; question of legality of contributions to Red Cross Society and purchase of Japanese war-bonds, $80-8 \mathrm{I}, 84$; legality of foreign enlistment, $82-83$, and n.; forbids fitting out, arming, or equipping of vessels intended for belligerent service, 83-84, 87 ; legality of loans by neutral individuals, 84-85, and n.; gifts of voluntary subscriptions to a fund raised in behalf of Greek revolutionists held to be contrary to, 86; of what use is a prohibition in, which can not be made effective, $86-87$; rules of, not devised to satisfy demands of logic, 87; probably forbids construction, sale and exportation of warships, $87 \mathrm{n}$.; the two twenty-four rules probably in process of becoming a part of, 86 , and n.; as also the rules limiting the supply of coal to neutral vessels in neutral ports, 88 and n., 89 n.; contention of Chancellor von Bülow that the sale of vessels of a private firm to a foreign state or to a private firm is admissible, 92, 110; questions of legality of construction, sale, and exportation by neutrals of warships, submarines and other vessels intended for belligerent service and responsibility of neutrals in such cases, $96 \mathrm{ff}$.; direct sale of war vessels by a neutral state to belligerent a gross breach of, 97 and n.; prohibits arming and equipping of such a vessel, as also augmentation of the force of a war vessel in a neutral port, $97 \mathrm{n}$.; 
additions to, usually the result of growth, $98 \mathrm{n}$.; decisions of prize courts an important source of, 98 n.; First Rule of Treaty of Washington a part of, 9799 and n.; American doctrine of intent, I02-103; meaning of "due diligence," I04-I05; the limits of the practical should not be passed in framing rules of, 107; forbids use of neutral territory as a base of military operations, II 2,124 and n. ; several new and unprecedented questions in, II5, I25; in dealing with, it is necessary to fall back upon fundamental principles of, or to seek for analogous cases in, II 5 ; rights and status of war correspondents and the use of wireless telegraphy, II5125; presumption in favor of laws of peace and rights of neutrals, II8-II9 and n., I28; the law of submarine cables, I22123 and n.; reply to Russian argument that everything is permissible in war unless expressly forbidden by, I28; opinions of authorities on the legality of setting adrift submarine mines on the high seas or of insecurely fastening them in neutral waters, I28-I30 n.; the threemile limit should be enlarged, I 32-I 34 and $n$.; Russian seizures and sinking of neutral prizes raise important questions in, I36, I47-148; confiscation of mail bags contravenes, 139-I40; status of Volunteer Navy, according to, I4I-I42, I48 and $n$.; sinking of the Knight Commander justified by Russia on the ground of, I46; the right of visit and search of neutral merchantmen, I48-153; question of convoy, I5O-I5I n.; right of visit and search as applied to mail steamers, I5I-I 56; Russian Prize Regulations at variance with, 158; established rule of, with respect to contraband, I65 n.; substantive principle of, can not be overridden by a technical rule of prize court, 180; permits neutral to trade in contraband, I86; important issues respecting rights and privileges of belligerent armed vessels in neutral ports and waters raised during the war, I88; twenty-four-hour rule, I89, 212-216; voyage of Baltic Fleet of interest to students of, 190; question of supply of coal to belligerent warships in neutral ports and waters, 190-198, 212-216; the spirit and letter of, violated by France in permitting the free use of her territorial waters to Russia, I 98 and n.; general rule as to supply of coal, according to, 198; speaks with uncertain voice in respect to supply of coal to belligerent warships, 203; President Roosevelt's decision in case of the Russian cruisers interned at Manila characterized as a new principle of, 210; custom hitherto governing rights of belligerent warships in neutral ports, 210-2I 2 ; binds neutral governments to a strict and impartial neutrality, 2I4; a new chapter of, has been written, 216; a new method for fixing responsibility for violations of, introduced by North Sea Commission, 240-24I ; rule of, respecting belligerent and neutral rights on the high seas, 244245 ; violation of Chinese neutrality a breach of, 249; law of, in respect to "double or ambiguous sovereignty," 249-25I ; no imperfect neutrality in, 263 ; wireless telegraphy on neutral soil, raises new question in, 266 ; a series of new precedents created, 267; Russian and Japanese Instructions in conformity with, 294; a belligerent has the right to expel enemy subjects in extreme cases, 298-299; prohibitions of, 301; should condemn naval bombardment as well as land, 307 n.; forbids enlistment of savages, 3ro; cases not included in the Hague Regula- 
tions remain under the protection of, 312 ; the bombardment of undefended coast towns by a naval force not in conformity with the best practice of, $3 \mathrm{I} 6$; Russian and Japanese rules relating to prisoners in conformity with, 318-3I9; Japan has set up new standards of, 319, 32I, 323; Japan sends advisors on, with each army corps, 324; Treaty of Portsmouth important from the standpoint of, 346347 ; does not forbid surrender of interned war-ships, $352 \mathrm{n}$.

International Law, alleged violations of: The Japanese attack upon the Russian fleets at Chemulpo and Port Arthur on Feb. 8 and 9, I904, $66 \mathrm{ff}$.; violation of Korean neutrality, $70 \mathrm{ff}$. ; charges against Germany for sale of vessels belonging to her Auxiliary Navy and the exportation overland of torpedo-craft to Russian territory, 9I-93, IIO-III ; purchase of vessels in England, Holland, etc., 93-94; construction and sale of submarines in United States and Great Britain, 94-96; cases of the Protector and Fulton, 94-96, I I2-II4; case of the Caroline, 96 ; the use of wireless telegraphy on the high seas by the Haimun, II7II 8 and n.; the laying of floating mines on the high seas, I25I27 and notes; Russian seizures of neutral merchant-men and sinking of neutral prizes, 136, I 38-I 47, I5 I-I 53, I56-I 59; confiscation of mail bags of the Prinz Heinrich, I39-I40, I55I56; case of the Malacca, I39I4I, I5I-I53; case of the Hipsang, I43 n.; case of the Knight Commander, 144-147, I56-160; Russia violates law of contraband, by ignoring distinction between absolute and conditional contraband, I66-I70; in the case of the Allanton, I7I-I73; in the case of the Knight Commander, 173-174; in the cases of the Arabia and Calchas, I74-I82;
Russia guilty of a violation of International Postal Treaty in the cases of the Calchas and Cincinnati, I77 n.; Russian violation of the neutrality of Egypt, 189; charges against France for permitting use of her ports and territorial waters, I89-198; Russian attack on British fishing fleet or North Sea Incident, 217246 ; alleged violations of Chinese Neutrality, 252-269 (see China and Neutrality); Russian sinking of Japanese vessels, 299301 ; violations of Hague and Geneva Conventions, 30I-307 and notes; use of Chinese clothing by Russian troops, 307-308; charges of mutilation of the dead and wounded, 308-309 and notes; enlistment of convicts, 300-3II ; bombardment of undefended coast towns, 3II-3I6; alleged use of lyddite by the Japanese and of dumdum bullets by the Russians, 316-3I7 ; failure of Russia to furnish Japanese with information regarding prisoners, 322 and 11.; general conclusion concerning, 323-324.

International Postal Convention, violated by Russia, I $77 \mathrm{n}$.

Internment of belligerent warships at neutral ports: The Mandjur, 198-189, 259, 367; the Czarevitch, at Tsing-tan, 204; the Diana, at Saigon, 205; the Askold and Grosovoi, at Shanghai, 205-206; the Lena, at San Francisco, 207-208 and $n$.; the three Russian cruisers at Manila, 209210, 2I5 n.; the Terek, at Batavia, 210 n.; views of Hall on, 2II; a series of new precedents in favor of, 215, 267.

Internment of belligerent troops on land, 76, 21 I, 216, 267.

Intervention of Russia in ChinoJapanese War, 7, 10, 327.

Italy, limits stay of belligerent warships in neutral ports to twenty-four hours, $88 \mathrm{n}$.; accepts Hay Note, 247 n.; replies to Hay Circular Note of I899, 300 and $n$. 
Ito, Count, negotiates Convention of Tien-tsin, $4 \mathrm{I}$; views of, $4 \mathrm{I}-$ 42 n.; negotiates convention with Korea, $75 \mathrm{n}$.

Japan, interests of, in China, 2,26 , $36,4 \mathrm{I}-42$ n.; recognizes independence of Korea, 7, 43, 47, 48; retrocedes Liao-tung Peninsula to China, 8; protests against the Alexieff-Tsêng Agreement, 19, 334; protests against the Lamsdorff - Yang - yu Convention, 22, 335; protests against demands of Russia regarding Russo-Chinese Bank, 24, 26; interests of, in Korea, 3, 26, 37, 4I42 n., 46, 359; enters into defensive alliance with Great Britain, 26-29, 336-337; protests against Russia's seven new demands, 36 , 337; relations with Korea, 3752 (see Korea) ; enters into negotiations with Russia, 53-60, 68 ; instigates China to refuse Russian demands, 57 ; accused by Russia of treachery, etc., $66 \mathrm{ff}$.; breaks off diplomatic relations with Russia, 61, 68-70; attack upon the Russian fleets justified, 68-70; reserves right to take independent action, $69-70$; violates Korean neutrality, 70 ff.; makes first aggressive movement, 70 $\mathrm{n}$.; accused of violation of International Law, 70-7I; replies to Russian note, 7I-72 ; impossible for, to respect Korean neutrality, 72; negotiates treaty with Korea, guaranteeing latter's independence and integrity, 73-75; extinguishes independence of Korea, 75 n., 356; demands surrender of rescued Russian sailors, 76 ; consents to their release on parole, 76 ; applies to the United States for permission to construct submarine cable, 78 ; orders battleships in England, 93; in competition with Russia for purchase of transports in Holland and Belgium, 93; agents of, negotiate for purchase of cruisers in South America, 94 and n.; agents of, order torpedo-craft in the United States, 94 ff.; fails to call attention of our Government to fact that submarines were being built, II 3 and n.; attempts to control movements of the Haimun, $118 \mathrm{n}$.; busy removing Russian mines, $126 \mathrm{n}$., 127 11.; practice of, in respect to destruction of prizes, $158 \mathrm{n}$.; publishes a list of contraband, 160-16I; recognizes doctrine of conditional contraband, I6r ; threatens force in case of Mandjur, I88; exchanges friendly communications with France, I89; complains of conduct of France in permitting use of her territorial waters, I90; makes representations to Spain, I9I n.; growing indignation in, due to prolonged stay of Baltic Fleet in French waters, I92-I94; makes representations at Paris, I93194; makes further representations at Paris, I94; statement of the case of, 194-I95; threatens to capture the Askold and Grosovoi at Shanghai, 205; addresses note to the Powers, 206; insists on same procedure as in cases of the Russian vessels at Tsingtau, $207 \mathrm{n}$.; claims that Russians violated parole, 207 n.; copies British restrictions upon liberty of belligerent warships in neutral ports, 2I3 n.; conditional acceptance by, of Hay Note, $247-248$; complains of numerous violations of Chinese neutrality by Russia, 259; attempts to justify seizure of the Ryeshitelni, $26 \mathrm{r}$; charges China with failure to observe neutrality, 26I and n.; refuses to offer apology for action of Ryeshitelni, 263; declares Russian charges without foundation, 264; denies use of Mia-Tao islands as a naval base, 265 ; charges of, against Russia, 265-267; observes all the requirements of the Hague Convention, $278 \mathrm{n}$.; issues Imperial Ordinance exempting Russian merchantmen from capture in 
certain cases, $281-282$; issues instruction to Government of Taiwan, 282-283; addresses a note to school teachers asking them not to encourage jingoism, 283 ; issues instructions to heads of religious sects, $283-284$; issues list of "Regulations Relative to Treatment of Prisoners of War," $284-285$; issues additional instructions, $285-287,285 \mathrm{n}$. ; issues Imperial Ordinance relative to Bureau of Information for prisoners of war, 289-290; issues "Regulations" relative to burial of the dead, 29I-294; a signatory of Hague Convention, 295; complains of hardships suffered by Japanese in Manchuria and Siberia, 298; requests good offices of the United States in behalf of destitute Japanese subjects, 298 ; conduct of, contrasted with that of Russia, $301 \mathrm{n}$.; explains firing upon Red Cross train, 302; accused of violating Hague and Geneva Conventions, 302, 305 ; protests against Russian use of Chinese clothing, 307 ; accuses Russians of mutilation of dead and wounded, 308-309 and n.; complains of Russian enlistment of convicts, 309; bombards Vladivostok, 3II ; accuses Russia of using dumdum bullets, 317 and $n$.; charges against, of using lyddite shells, 3I6; sets up new standards of International Law, 319, 321, 323; establishes Bureau of Information, 319-320; kind treatment of sick, wounded and prisoners by, 319-322; conduct of, during the war, 324 ; complains of failure of Russia to furnish information concerning prisoners, 322 and n.; coöperates with England and the United States in the Far East, 325, 333-335 and n.; approves British lease of Weihai-wei, 328 ; replies to Hay Circular Note of September 6, 1899, 330 ; concludes com mercial treaty with China, 338 n.; para- mount interests of, in Korea, acknowledged by Russia, 34I ; agrees to evacuate Manchuria, $34 \mathrm{I}-342,345,355$; sends favorable reply to President Roosevelt's Note suggesting peace negotiations, 349 ; proposes twelve conditions of peace, 350-35I ; withdraws demand for indemnity, 355; summary of gains of, at Portsmouth, 355-356; concludes offensive and defensive alliance with Great Britain, 357; recognizes special interests of Great Britain in India, 358-359.

Jefferson, on right of neutrals to trade in contraband, $185-186$.

Jemtchug, interned at Manila, 2092 Io.

Jibutil, coaling at, 189, I94, 195.

Kaimimura, Vice-Admiral, humane conduct of, $30 \mathrm{I} \mathrm{n}$.

Kamchatka, the, fires upon the Aldebaren, 218 n., 223 n., 238 n.

Kamranh Bay, Baltic Fleet at, 190, 193, 194, 196.

Kaneko, Baron, interviews with President Roosevelt, 354-355 n.

Kennan, George, on Japan's treatment of the wounded, 32I.

Kiao-chau, I2, 204; leased to Germany, 15, 327.

Kiushiu Maru, the, justifiable sinking of, by Russians, 300301.

Kirin, province of, 30, 34 .

Knight Commander, case of the, I 44-I 47, I56-I 59, I 73-174 n., 339.

Korietz, the, accused of firing the first shot in the war, $70 \mathrm{n}$.; crew of, rescued at Chemulpo, $75,77 \mathrm{n}$; ; crew of, violates parole, $207 \mathrm{n}$.

Korea, independence and territorial integrity of, $7,26,28,29 \mathrm{n}$., $37,40,43,47-48,53-56,7 \mathrm{I}-$ 75, 356; Russian troops in, 34; encroachments of Russia in, 36 ; geographical location of, 37; open door policy in, 4I, 54, 56; treaties of, with foreign Powers, $4 \mathrm{I}$; insurrections of $\mathrm{I} 882$ and of $1884,4 I$; insurrection of 1894 
results in Chino-Japanese War, 43 ; coup d'état of $1895,43-44$; murder of Queen, 44; uprising in, 44; independence of, recognized by Japan and Russia, 4748 ; rivalry of Russian and Japan in, $48 \mathrm{ff}$.; anarchy in, $5 \mathrm{I}$; excluded from application of Hay Note, $346 \mathrm{n}$.

Korea, relations of, with China: Chinese claim of suzerainty over, 37 and n., 39; effect of Mongol conquest on, 38-39; ascendency of Chinese interests and influence in, 39; first and second Chinese and Japanese intervention in, $4 \mathrm{I}$; third Japanese and Chinese intervention in, results in Chino-Japanese War, 43 ; rivalry of Russia and Japan in, $48 \mathrm{ff}$.

Korea, relations of, with Japan: Interests of Japan in, $1,3,26$, $37,4 \mathrm{I}-42$ n., 46, 52-55, 359; temporary subjugation of, by Japan in third century, A. D. 37 ; regarded as a tributary state, 37 ; tribute missions to, 38-39; commerce and immigration, 38 ; effects of Mongol conquest of, 38 ; invasion of Hideyoshi, 39; reassertion of Japanese claims of suzerainty over, 40, 43; Japan recognizes independence of, 40 ; Chinese and Japanese intervention in, 4I; Japanese attempts at reform in, 43; coup d'état of 1895, 43; counter-plot to seize King and Queen, 44; Memorandum of May 14, 1896, regarding, 45 and n.; YamagataLobanoff Protocol regarding, 45-46; Nishi - Rosen Protocol regarding, 47-48; rivalry of Russia and Japan in, 48 ff.; ultimatum of Mr. Hayashi, 5I; negotiations regarding, 52 ff.; increased Russian activity in, 56 ; neutral zone proposed, 5659 ; alleged violation of neutrality of, by Japan, $70 \mathrm{ff}$.; is within Japanese "sphere of influence" and one of the main objects of the war, 72; the Powers warned that Japan's acts in Korea are invalid, 72 ; independence and integrity of, guaranteed by Japan, 73-74; independence of, extinguished by Japan, 75 n., 356; Great Britain recognizes Japan's paramount interests in, 358-359.

Korea, relations of, with Russia: Russia tries to obtain Port Hamilton, 42; agrees not to occupy Korean territory, 43; concludes a commercial convention with, 43; obtains control of Korean Government, 44; brief period of Russian ascendency in, 44-45; obtains timber and mining concessions in, 45; Memorandum of May 14, I896, regarding, 45 and n.; Yamagata-Lobanoff Protocol regarding, 4546; violation of, by Russia, 4647; Russia tries to obtain control of Korean army and finances, 46 ; dismissal and restoration to office, of Mr. Brown, 46-47; visit of British men-of-war, 47; the Nishi-Rosen Protocol regarding, 47-48; independence of, recognized by Russia, 47 ; rivalry of Russia and Japan in, 48 ff.; Russia attempts to lease Masampo, 49 ; to obtain a foothold on Korean territory, 50-5I ; attempts to obtain extension of Yong-am-po lease, 5I; Russia acknowledges Japan's paramount interests in, 341, 355; Russian subjects in, 34I ; Japan demands recognition by Russia of her paramount interests in, 350.

Komura, Baron, negotiations with Russia prior to war, 52-53, 57, 58,59 ; replies to Russian protest, 306; peace plenipotentiary at Portsmouth, 349, 352, 355.

Krabri, the, detains the Osiris, I39 $\mathrm{n}$.

Kurino, Mr., the Japanese Minister at St. Petersburg, 52, 53, 59, $69,70$.

Kuropatkin, General, on occupation of Manchuria, I8 n.; on Japanese observance of the rules of war, 323-324. 
Kurile Islands, exchanged for Sakhalin, 6.

Kwang-Chau Bay, leased to France, 16, 328.

Lamsdorff, Count, I66 n., 181, 219, 222 11., 232 n.; on occupation of Manchuria, I8 n.; denies Alexieff-Tsêng Agreement, 19; admits modus vivendi, 19-20; on evacuation of Manchuria, 20; agreement of, with Yang-yu, 2I22 ; reply of, to Hay, 25 ; assurances by, 25; denies Russian demands, 34 n.; negotiations with Japan, 53-59; Circular Note to the Powers (Feb. 22, I904), 67, 70-71; warns Powers that Japan's acts in Korea are invalid, 72 ; requests British Govemment to convey orders of the Russian Government, I42 n. ; orders captains of Russian cruisers to abstain from sinking neutral vessels, I43 n., I82 and n.; reports decision in case of the Arabia, I76 n.; gives assurances to Great Britain, I83 n.; negotiations of, respecting North Sea Incident, 219 n., 222, 225, 229231.

Lamsdorff-Yang-yu Convention, terms of, 2I-22, 335 .

Lansdowne, Lord, I I 7 n., I 42 n., I 44 n., I45 n., I97, 232, 335 n. ; communication of, regarding AngloJapanese Agreement, 27-28; on contraband, I79; on chartering of vessels for trade in coal, 203204 and n.; negotiations of, respecting the North Sea Incident, 219-22I, 224-225, 228-230, 238; on British policy in China, $338 \mathrm{n}$.

Lawrence, T. J., on declarations of war, 64 n.; on the validity of treaties made under duress, 7475 ; on enlistment, 83 ; on the legality of loans, 85 ; on legality of voluntary gifts and subscriptions, 86; on First Rule of Treaty of Washington, 98 n.; on American doctrine of intent, 102; on "due diligence," 105; on the case of the Haimun, I I6 n.; on fundamental principle of law of neutrality, II8 and n.; on status of war correspondents, $120 \mathrm{n}$.; on wireless telegraphy, I23 n., I24 n.; on the case of the Hatsuse, 126 n.; on submarine mines, $129 \mathrm{n}$.; on the right of search of mail steamers, I 54 and $\mathrm{n}$.; on the destruction of prizes, $156 \mathrm{n}$.; on the case of the Allanton, I7I n.; on the case of the Nancy, I72 n.; on the Knight Commander, $174 \mathrm{n}$.; on right of neutrals to trade in contraband, I84, I87; on violation of neutrality of Egypt, I89; on increasing importance of coal in naval warfare, $20 \mathrm{I}$ and $\mathrm{n}$.; on distinction between hostile and peaceful use of coal, 20I-202; on right of asylum, 210 ; on British neutrality regulations, $2 \mathrm{I} 3 \mathrm{n}$.; on repairs permitted to belligerent warships in neutral ports, 2I 5 and n.; on case of the General Armstrong, 263 n.; on "Days of Grace," 296 and 297 $\mathrm{n}$.; on the sinking of Japanese merchantmen, 300 and n.; justifies action of Japanese in firing upon Red Cross train, 302; on bombardment, $314 \mathrm{n}$.

Laws of Warfare (see Warfare).

Leases in China, 15-16, 327-328, 330 and n., 339; of the Bay of Kiao-chau by Germany, I5, 327; of Port Arthur by Russia, I5, 327; of Wei-hai-wei by Great Britain, I5, 328; of the Kwangchau Bay by France, 16, 328 .

Lena, the, interned at San Francisco, 207-208 and $n$.

Lessar, M., 23-24, 32-33, 57, r88 n. Liao River, $30,33,34,36$; controversy regarding neutrality of region west of, $255-258,265-267$.

Liao-tung Peninsula, 7-9, 341, 342, $345,35 \mathrm{I}, 356$.

Li-Hung Chang, appeals for intervention against Japan, 7 ; favors "open door" in Korea, 40; negotiates Convention of Tien-tsin, 4r.

Loans, movement in United States to contribute to Japanese war fund, $80-81$; not a violation of 
International Law, 8I ; Japanese loans floated in England and United States, $8 I$; communication from Secretary Hay to Mr. Takahira regarding, 8I ; Russian loans in France, 82; legality of, denied by some publicists, 8485 and n.; not an infringement of neutrality if entered into with commercial views, $86 \mathrm{n}$.

Loomis, Secretary, statement of, regarding the Fulton, 95.

Lyddite, Japanese accused of using shells charged with, 316.

Madagascar, Baltic Fleet at, I9I, I92, 193.

Mail Steamers, searched by Russia, I39; right of search of, I39, 153-I56; case of the Prinz Heinrich, I39, I55-156; cases of the Calchas and Cincinnati, I77 n.

Malacca, case of the, 139-142, I5II 53 and n., 339.

Manchuria, Japanese interests in, $3,7,52,56$; interests of Russia in, 3 and n., $54-55$ and n., 56; railways in, I0-I6, $18,21,256$ n., $327,335,342-343,345,35 \mathrm{I}$, 355; occupied by Russia, I6 ff., 333 ; Russian Circular Note regarding, pp. I7-18; modus vivendi relating to, is n., I9-20; Count Lamsdorff on evacuation of, 20; to be restored to China, 2I ; Alexieff-Tsêng Agreement regarding, 18-19, 334; the Lamsdorff-Yang-yu Convention regarding, 2I-22, 335; Russia on evacuation of, 22-23; Russian proposals to evacuate, 23-24; Russian demands concerning, 24; Convention of Evacuation regarding, 29-32, 337; difficult to fulfill, 32-33; evacuation of region west of the Liao River, 33, 256; failure to evacuate the rest of, $34,36,256$ and n., 337; Russia's seven new demands regarding, 34-35; six fresh demands by Russia relating to, 36 n., 57 ; the right of foreign settlements in, 36 n., 58 n., 338 n.; aggressive and exclusive policy of Russia in, 36; negotiations be- tween Japan and Russia concerning, 52 ff.; increasing Russian activity in, 56; excluded from application of Hay Note, 246 11., 249, 253, 258, 265; international status of, 249-25I, 253; Admiral Alexieff's proclamation to inhabitants of, 25I-252; activity of Chinese troops along frontier of, 254-255 and n.; Chinese bandits in, 252, 254-255; neutrality of that portion of, west of the Liao River, 255-258; Japanese subjects suffer in, 298; burning of Chinese dead in, 304; use of Chinese clothing in, 307 ; use of dumdum bullets in, 3I7; German interests in, $334 \mathrm{n}$.; opening of Mukden and Antung in, to trade, $338 \mathrm{n}$.; Japan and Russia agree to evacuate, 34I342,345 ; Japanese proposals regarding evacuation of, $350-35 \mathrm{I}$; results of, 356 .

Manchurian Railway (see Chinese Eastern Railway).

Mandjur, the, interned at Shanghai, I88-189, 206-207 n., 259, 26r, 267.

Manila, 79, I96; the Russian cruisers interned at, 209, $215 \mathrm{n}$.

Maria, case of the, I49, I5o n.

Marianne Flora, case of the, $242 \mathrm{n}$.

Marine League (see Three-mile limit.)

Marshall, Chief Justice, on privileges of public ships in neutral ports, 262 .

Martens, Professor, I78, I82, 230, 27 I-272 n., 323, 349 n., 353-354 n.

Masampo, 37 n.; attempts of Russia to leasc, 49 .

Matilda, seizure of the, $\mathrm{I} 37 \mathrm{n}$.

McCormick, American ambassador at St. Petersburg, 165 n., I76 n., $322 \mathrm{n}$.

McKinley, President, Proclamation of (April 26, 1898), 296297 and $n$.

Mediation, Hague Conference on, 347.

Mediterranean fleet, R us i a n, search and detention of neutral merchantmen by, in Red Sea, I36-I38; projected voyage of, to 
the Far East, I37; return of, to the Baltic, I38; stay of, at Jibutil, IS9.

Memorandum of Russian and Japanese Ministers at Seoul, terms of, 45 and $n$.

Merchantmen, neutral, sale of, to belligerents not illegal, 93, I I0; Russian seizures of, 136, I38I39, I43-I44, I5I-I53; search and detention of, in Red Sea, I36-I37; sinking of, I43-I47, 156-159; sinking of the Thea and Knight Commander, I44147, I56-I59; Russia instructs naval commander not to sink, I 43 n., I46; vessels of Volunteer Fleet in the guise of, $138,15 \mathrm{I}$; right of visit and search of, I48153; can not exercise right of visit and search, 143-147, I56I59; Great Britain protests against sinking of, I44-I 45, 178 .

Merchantmen, Japanese, sinking of, by Russians, 299-30r.

Merchantmen, enemy, in belligerent ports at outbreak of war, Russian rules relating to, 269, 295-296; Japanese rules relating to, 281-282, 295-296; recent practice respecting, 296-297 and n.

Metcor, case of the, 100 n., IOI, I07.

Mia-Tao Islands, use of, by the Japanese, 258-259, 265, 266.

Mikado, issues Imperial Rescript announcing retrocession of the Liao-tung Peninsula, 8; decides in favor of peace, 355 .

Militia, conditions under which, may be considered as belligerents, 272; must wear distinctive emblem, 272, 307-308.

Military occupation, Hall on, 250251 ; rights of, 253, 275.

Mines, submarine, set adrift on the high seas or insecurely fastened in territorial waters by Russia, 125-126 and n.; Japan also lays, I26 n.; United States institutes an investigation regarding, 126I27 n.; Conger reports regarding, 127 n.; distribution of, 127 n.; the laying of, on the high seas a gross violation of the laws of war, $128-\mathrm{I} 30$ and $\mathrm{n}$.; license of practice respecting laying of, I 30 and n.; states a right to employ, inside the three-mile limit, I30; conditions under which they may probably be used on high seas, I3I and n.; rules of Institute of International law relating to, I35 n.; questions relating to, should be referred to next Hague Conference, 134 ; tentative statement of the law of, 134 and $n$.

Mischenko, General, raid of, 266; reports effects of lyddite shells, $316 \mathrm{n}$.

Miura, Japanese Minister at Seoul, 44 and $\mathrm{n}$.

Modus vivendi relating to Manchuria, I8 n., 19-20.

Mongolia, 22, 32, 34, 35, $246 \mathrm{n}$.

Moore, John Bassett, on floating mines, 129 n.; on report of North Sea Commission, 239-240.

Movables, of enemy state, 273 ; of individuals, 274.

Mukden, city of, sham evacuation of, 34 n., 256 and n.; reoccupied, 36 and n.; opened to trade, 338 and n.; battle of, 347 .

Mukden, province of, $30,33,34$.

Myer, American Ambassador at St. Petersburg, 354 n.

Nakonoura Maru, the, justifiable sinking of, by Russians, 299$300 \mathrm{n}$.

Nancy, case of the, I50 n., I72 n.

Naval War Code of United States, $297 \mathrm{n}$.; on convoy, I5I n.; on search of mail steamers, 153 ; on destruction of prizes, $158 \mathrm{n}$.; on contraband, I69; on naval bombardment, 3I3-3I $5 \mathrm{n}$.

Negotiations, leading up to Russo-Japanese War, 52-60, 68 and n.; leading up to North Sea Commission, 225-23I ; summary of, by Premier Balfour, 226; leading up to Treaty of Portsmouth, 346-355; the twelve Japanese conditions of peace, 350$35 \mathrm{I}$; controversy regarding ces- 
sion of Sakhalin and indemaity, 352-355.

Netherlands, the, limits stay of belligerent warships in neutral waters to twenty-four hours, 88$89 \mathrm{n}$.; interns the Terek at $\mathrm{Ba}-$ tavia, 2 Io n.; copies British restrictions upon belligerent warships in neutral ports, $213 \mathrm{n}$.; accepts Hay Note, $n$.

Neutrality, alleged violation of, by Japan in Korea, 70-75; by Germany in permitting sale and delivery to Russia of vessels belonging to her Auxiliary Navy, etc., 9I, 110; by United States in permitting construction and exportation of torpedo boats, 9495, I 12-114; by Great Britain in permitting delivery of the Caroline, 96 and n.; by Russia and Japan in laying submarine mines, I25-127 and notes; by Russia in seizure and sinking of neutral vessels, I36-I 59 ; by Russia in respect to contraband, $160-$ 183; by Russia in Egypt, I89; by France in permitting the use of her ports and waters by Baltic Fleet, I90-198. (For violations of Chinese neutrality, see China, neutrality of.)

Neutrality, rights and obligations of (see also International Law and Neutrals, rights of), as affected by war, 62,67 ; obligations of, best fulfilled by interning rescued sailors, 76 ; expressions of opinion and sympathy not a violation of, 79-80; contributions to Red Cross Society or purchase of Japanese war bonds, not a violation of, $8 \mathrm{I}$; foreign enlistment not necessarily a violation of, $82-83$; conduct of the United States in respect to, 78-90; practical expression of sympathy for wounded, etc., permissible, 84 ; gifts or voluntary subscriptions to a fund in behalf of Greek revolutionists held to be inconsistent with, 86 ; loans not an infringement of, if entered into with commercial views, 86 n.; President Roose- velt's Proclamation of, $87-88$; officials of United States warned by President Roosevelt to observe obligations of, 89 ; forbids giving support to either belligerent, 92 ; obligations of, in the matter of the construction, sale, and exportation of warships, submarines, and other vessels intended for belligerent service, 97-109; direct sale of war vessels by a netutral state a gross breach of, 97 and n.; a neutral state bound to use due diligence in the enforcement of, 97-98, 104-106; to prohibit trade in arms and ammunition would be too great a burden on, I07; not mere impartiality but total abstention the rule of, III, 2 I4 ; presumption in favor of the laws of peace, a fundamental principle of, II8-II9 and n.; questions relating to, should be referred to next Hague Conference, I34; the Russo-Japanese war an important epoch in history of, 160 ; voyage of Baltic Fleet an illustration of defects in law of, 198; essence of, that no aid be given to belligerents, 20I; French "Instructions," as also British and American rules, insufficient for maintenance of, 202 ; obligations of, in respect to the twenty-four hour rule, 213-216; as to supply of coal to belligerent warships in neutral ports, 213-216 ; as to repairs of belligerent warships in neutral ports, 215 and $n$.

Neutrals, rights of, presumption in favor of, II8-II9 and n., I28; threatened by Russia in the case of the Haimun, II5-II9; in respect to wireless telegraphy and submarine mines, II - -I35 n.; violated by Russian seizures and sinking of neutral merchantmen, I36-I59; in respect to contraband, $160-187$; rights of, in respect to belligerent fleets or warships on the high seas, 227$228,242-245$; territorial sovereignty must be respected by bel- 
ligerents, 249, 261-263; duties of (see Neutrality, rights and obligations of).

Neutrality Laws of United States, $8 \mathrm{r}, 82$ and n., 83, 84, 87, 97 n., 99-100 and n., 102, 108, I ro n., II2, II4 n.; of Great Britain (see Foreign Enlistment Acts).

Neutrality Proclamations, recent, lay down the twenty-four hour rule and limit the supply of coal to belligerent warships in neutral waters, 88-89 n., 198-199 and $\mathrm{n}$.; on trade in contraband, 185 n.; of many countries merely enjoin observance of neutrality, $199 \mathrm{n}$.

Neutral territory, use of, for military purposes, at Che-Foo, I22 n., $124 \mathrm{n}$.

Neutral waters (see Waters, neutral).

Neutralization of the sick and wounded, field ambulances, military hospitals, etc., 272-273; temporary as opposed to permanent, 248.

Niu-chwang, seized by Russia, 16; Russia promises to restore, 19; Russian note regarding surrender of, 32; evacuation of, delayed, 33,35 and n., 36 ; conditions of evacuation, 57 ; question of neutrality of, $255-258$, 259, 26r n., 265-266; remains in possession of Russia, 256 and n.; proclamation of martial law at, 257; foreign consuls at, deprived of some of their functions, 257-258; Japanese refugees at, maltreated, 298.

Nishi-Rosen Protocol of 1898 , text of, 47-48.

Nogi, General, replies to General Stoessel, 305-306.

Non-belligerents (see Neutralization).

Non-combatants may be made prisoners, 120 n., 277; not to be injured if peaceable, 280 ; treatment of, during Boer War, 295 n.; Russia refuses to treat as, those who refuse to surrender, 301 ; Japanese regard for rights of, 324. (See also Inhabitants of enemy country.)

North Sea Commission (see also North Sea Incident); idea of, suggested, 224, accepted, 225 and n., 226; negotiations regarding organization and scope of, 228233 n.; Declaration of St. Petersburg on, 231-233; combines function of a court of arbitration and court of inquiry, $233 \mathrm{n}$., 240-24I and n.; meeting and composition of, 234 and n.; degree of publicity, $234 \mathrm{n}$.; report of, $236-238$ and n.; criticism of report, 238-240; Moore on, 239240 ; a great victory for principle of arbitration, 240; no precedents for finding of, $24 \mathrm{I}-242$ and $\mathrm{n}$.

North Sea Incident (see also North Sea Commission), IgI, 217-246; description of, 217-218 and n., 221-222, 238 n.; anger and excitement caused by, 218 and n., 220, 223-224; Admiral Rojestvensky's explanation of, 22I-223; negotiations relating to, $224 \mathrm{ff}$.; Premier Balfour on, 226-228; International Commission of Inquiry on, 233-238; British and Russian "Conclusions" on, 235; character of evidence bearing on, 236 and $n$.; report of Commission on, 236238 and $\mathrm{n}$.; attitude of United States toward, 339.

Nossi-Be, Baltic Fleet at, I90, 192, 193, 195.

Norway-Sweden, limits stay of belligerent warships in neutral ports and supply of coal in neutral waters, 88-89 n.; closes ports and fjords to belligerent warships, 89 n., I99 n., 2 I I n.; copies British instructions upon liberty of belligerent warships, I99 n., 2II n.

Novik, the, seeks refuge at Tsingtau, 204.

Oleg, the, interned at Manila, 2092 IO.

"Open Door" in China, 2, 24, 25, $26,28,35,54,56,328,330$ and $n$., 
$331-332, \quad 334-338$ n., $356-357$, 359 ; in Korea, 41, 54, 56.

Orient (see Far East).

Osiris, the, detention and search of, $139 \mathrm{n}$.

Outbreak of war, effect of, 62 ; subjects of enemy state found in belligerent territory at, Russian rules relating to, 269,295 , 297; Japanese rules relating to, $282-284,295,297$; "days of grace" allowed to enemy merchantmen in belligerent ports at, Russian rules relating to, 269 ; Japanese rules relating to, 281282 ; recent practice respecting, 296-297 and $n$.

Oyama, Marquis, on use of dumdum bullets by the Russians, 317.

Parole, Russian violation of, by crews of the Variag and Korietz, 207 ; n.; by three Russian officers of the Lena, $208 \mathrm{n}$.; by the officers of the Ryeshitelni, 259260; by Russian officers at Port Arthur, 32I.

Pascal, the, rescues Russian sailors at Chemulpo, 75 and $n$.

Pavloff, M., Russian representative at Seoul, 48, 49, 5I, $7 \mathrm{I} \mathrm{n}$.

Peace Conference at Portsmouth, 349-355; President Roosevelt urges, 347-348; composition of, 349 and $n$.; language question at, 350; twelve Japanese conditions of peace, 350-35I ; negotiations relating to, $351-355$; bearing of Anglo-Japanese Alliance on, 356-357.

Peace, laws of, presumption in favor of, II8-1 I9 and n., 128.

Pe-chi-li, Gulf of, 15, 117, 125, 126 n., 258-259, 328 .

Peking, 5, 188, 327, 332, 333 n., 356.

Peterburg, the, searches and seizes neutral vessels in the Red Sea, 138; seizes the Malacca, 139; legality of commission of, 151-153 and n.

Petropavlovsk, the, destroyed by a Japanese mine, $126 \mathrm{n}$.

Philippine Islands, 78, 327.
Pillage, prohibited, 253, 274.

Piracy, charges of, against Russia, $66,140,233$.

Pleiades, the, detained for strategic reasons, $137 \mathrm{n}$.

Poison, use of, prohibited, 274.

Port Arthur, 7, 12, I17, I19, 122 n., 124 n., 125, 126 n., I32, I36, 258-259, 266-267, 298; leased to Russia, 15, 47, 256 n., 327 n.; Japanese attack on Russian fleet at, 66, 70; Russian fleet at, 138, 204 ; seige of, 302-306, 321 ; lease of, transferred to Japan, 342,347 , $35 \mathrm{I}, 356$.

Port Hamilton, seized by Great Britain, 42 ; evacuated, 43.

Port Said, 189, 191, 192.

Ports, belligerent, "days of grace" allowed to enemy merchantmen in, at outbreak of war, Russian rules relating to, $269,295-296$; Japanese rules relating to, $28 \mathrm{r}-$ 282, 295-296; recent practice respecting, 296-297 and $\mathrm{n}$.

Ports, neutral, rights of belligerent armed vessels in (see also Warships, belligerent), 160, I88216, 262-263; abuse of hospitality of, 189; supply of coal in, 191-203, 210-216; instances of prohibition of entry, 199 n., 210$211 \mathrm{n}$.; length of stay in, 210214 and notes, 216; repairs in, 2II, 214-215; right of asylum in, 210 and $n$.; views of authorities on, 211-2I2 and notes; Balfour on, 214-215; Chief Justice Marshall on, 262.

Portsmouth, Peace Conference at (see Peace Conference).

Portsmouth, Treaty of, 34I-359; signed and ratified, $34 \mathrm{I}$; terms of, $341-346$; provisions for ratification, signing, and interpretation of, 344-345; importance of, 346-347; negotiations leading up to, 346-355; results of, 355-356.

Portugal, enforces twenty-four rule during Spanish-American War, 213 n.; accepts Hay Note, $247 \mathrm{n}$.

Powers, the, intervene to secure retrocession of Liao-tung $\mathrm{Pe}$ - 
ninsula, 8; Russian Circular Note to (July I3, I900), I7 n.; Russian Circular Note to (August 28, I900), I7-18; protests of, I9; appeal of Emperor of China to, 22, 334-335; protests of, 24 ; the Russian Note to (February 22, 1904), 67, 70-71; warned that Japanese acts in Korea are invalid, 72 ; three rules of Treaty of Washington never formally acepted by, 98 and $n$.; notified by Russia that war correspondents may be treated as spies, II6-II7; fail to protest against passage of the Straits by Russian vessels, I39; guarantee the neutrality of China, I88 n., 247249; Japan addresses note to, threatening to use force in case of the Askold and Grosovoi, 206; conduct of, in refusing or limiting supply of coal to Baltic Fleet, 216; favorable replies from, to the Hay Note, 247 ; Circular Note (Jan., I905) to, specifying five breaches of Chinese neutrality, 258-259; Secretary Hay suggests Conference of, 268; Russian protest to, against action of Japanese in firing upon Red Cross train, 302 ; about to partition China, 327; violate territorial integrity of China, 328; Hay Circular Note to (Sept. 6, I899), 329-330; replies of, to Hay Note, 330-33I and n.; second Circular Note to, 332 ; repeatedly pledge themselves to maintain open door and territorial integrity of China, 332 .

Preemption, the right of, $162 \mathrm{n}$., I64 n., I67.

Princess Marie, the, sinking of, I43 n., I47 n.

Prinz Heinrich, case of the, I39, I55-I56.

Prisoners of war, war correspondents may be made, I2O-I2I and n.; persons transmitting wireless messages to be treated as, I35 n.; treatment of, according to Russian "Instructions," 277278,280 and n.; according to
Japanese "Regulations" and "Instructions," 284-29I ; kind and amount of labor required from, 285 n.; postal articles for, 287 288 ; postal orders for, 288 ; duties of Bureau of Information for, 298-29I ; treatment of, during the Boer War, 295 n.; Russian and Japanese rules relating to, in conformity with International Law, 3I8-3I9; Japanese treatment of, 319-322, 324; Russian treatment of, $322-323$ and n.; provisions in Treaty of Portsmouth relating to, 344 .

Prize Courts, decisions of, an important source of International Law, $98 \mathrm{n}$.

Prize Court at Vladivostok, condemns the Allanton, I7I-I72; condemns the Cheltenham, I73 n.; condemns the Knight Commander, 174; condemns part of cargoes of Arabia and Calchas, I76-177; attempted justification of decisions of, I78; criticism of, by Secretary Hay, 18I.

Prizes, neutral, alleged right of destroying, I36, 156-159; sinking of, by Russia, I43-147, 156 159; justification of, by Russia, I46; distinction between destruction of enemy and neutral, 156-158 and n.; Prof. Holland on, $157 \mathrm{n}$.; modern usage relating to, 157 n.; Russian Prize regulations on, I46, I47 n., I58 and $n$.

Proclamations: of Admiral Alexieff to inhabitants of Manchuria, terms of, 25I-252; of the Governor of Malta forbidding supply of coal to belligerent fleets or warships, 200, 202; of President McKinley at outbreak of Spanish-American War, 296297 and n.; of neutrality by President Roosevelt, terms of, 87-89. (See also Neutrality Proclamations.)

Projectiles dropped from balloons or intended to spread asphyxiating fumes, Russia agrees to observe declarations prohibiting use of, 271, 317-318 and $n$. 
Protest of the three captains at Chemulpo, $7 \mathrm{I}$ and $\mathrm{n}$.

Protocols :

Yamagata-Lobanoff terms of, 45-46.

(I8g6),

Nishi-Rosen (I8g8), text of, 47-48.

Peace Protocol (Sept. 7, 1901), between China and the Powers, 333.

Protector, case of the, 94-95, I12I 14.

Prussia, allows "days of grace" in $1870,296$.

Quarantine station, fired upon, 306.

Quarter, must be given, 274, 280 .

Railways (see also Chinese-Eastern Railway, Manchuria, TransSiberian Railway), Manchurian, I0-16, I8, 21, 256 n., 327, 335, $342-343, \quad 345, \quad 351,355-356$; agreement regarding, I3-I4; "Statutes" relating to, I3-I4; police agents for, I4; railway guards for, 18, 33; China to protect, 24; restoration of the Shan-hai-kwan - Niu-c h w a n g Railway to Russia, 3I ; Korean, between Seoul and Fusan, 48 n., 50 ; the question of construction of the Seoul-Wiju Railway, 50.

Ransom, whether permissible in case of bombardment by a naval force, 314-3I5 $\mathrm{n}$.

Red Cross badge, medical and sanitary personnel shall wear, 273; use of, to deceive the enemy prohibited, 274; not to be fired upon, 28I; abuse of, 301 ; fired upon, $309 \mathrm{n}$.

Red Cross flag, hospitals, etc., shall carry, 273; use of to deceive the enemy forbidden, 274; not to be fired upon, $28 \mathrm{I}$; fired upon, 302, 305-306, 309 n.; abuse of, 303 .

Red Cross Society, movement to raise a fund for, $80-81$ n.; communication from Secretary Hay to $\mathrm{Mr}$. Takahira regarding. $8 \mathrm{I}$; no sound objections to contributions to, 84 .

Red Sea, Russian seizures of vessels in, 136, I38-142, I48; search and detention of neutral vessels in, 136-138.

Ref ugees, Japanese at Niuchwang and Port Arthur maltreated, 298.

Regulations respecting warfare on land of Hague Conference, Russia agrees to observe, 270, 271 n.; Art. I of, $271-272$ n.; compared with Russian "Instructions," 272 n., 275 n., 278 n., 279 n., 285 n., 286 n., 287 n.

Repairs of belligerent warships in neutral ports, $2 \mathrm{II}-2 \mathrm{I} 5$; in the case of the Czarevitch, 204; of the Askold and Grosovoi, 205206; of the Lena, 207-208; in case of the three Russian cruisers at Manila, 209-2IO, 2I5 n.; views of authorities on, 2I I n.; Lawerence on, 2I5 and $n$.

Report of North Sea Commission, 236-238 and n.; criticism of, 238-240; Moore on, 239-240.

Requisitions, for military purposes permissible, 253; conditions under which they may be imposed, 275 and $n$.

Rojestvensky, Admiral, I90-192, I94-I95, 2 I8 n., 219, 220; interviews with, 22I-222 and n.; official telegrams of, 222-223; suffers from nervousness, 223 n.; ordered to remain at Vigo, 225; receives instructions from Russian Government, 226 n.; criticised by Premier Balfour, 227; receives secret code of instructions from Russian Admiralty, 228 n.; responsibility of, 223 , 235-240.

Rosen, Baron, negotiations of, with Japan, 55,56 n., 57 ; at Portsmouth, 349. 353 and $n$.

Roosevelt, President, Proclamation of Neutrality (Feb. Io, 1904), 87-88; Executive Order of, 89; orders that the Lena be disarmed, 208; decides that the Russian vessels at Manila must either dismantle or disarm with- 
in twenty-four hours, 209; important precedent set by, $215 \mathrm{n}$.; on policy of England and United States in China, 331; purpose of, in China, 332; plays leading part in peace negotiations, 346; sends identical note to Russia and Japan urging peace negotiations, $347-348$; interview with Baron Rosen, 355 and n.; proposes cession of Sakhalin and repurchase by Russia, 353-354 n.; appeals to Czar, 354 and n.; appeals to Mikado, 354-355; interviews with Baron Kaneko, 354-355 n.

Rules of warfare, Russian and Japanese (see Warfare, rules of).

Rurik, the, sinking of, $30 \mathrm{I}$.

Ruses of war allowable, 301 .

Russia, interests of, in the Far East, 2-3, 28; expansion of, 3-4; conquest of Siberia and advance to the Pacific, 4-6; acquisition of Manchuria, 5; intervenes to secure retrocession of the Liaotung Peninsula, 7, 327; ultimate designs of, 9; concludes Cassini Convention, 10-12; leases Port Arthur and Talien-wan from China, I5, 327; occupies Manchuria, I6 ff.; seizes Niuchwang, I6; sends Circular Note to the Powers, I6-17; lays down fundamental principles, I7 n.; promises to withdraw her troops, 18; promises to restore Niu-chwang to China, 19; agrees to restore Manchuria, 2I ; the Lamsdorff-Yang-yu Convention, 22; fails to evacuate Manchuria, 22-23; makes fresh demands on China, 23-24; assurances by, 25; demands on China regarding Russo-Chinese Bank, 24; ceases to press China, 26 ; accepts counter proposals, 26,29 ; declaration of, regarding Anglo-Japanese Agreement, 2829 ; note regarding surrender of Niu-chwang, 32 ; convention for evacuation of Manchuria, 29-32, 256 and n., 337; evacuates region west of the Liao-River, 33,
256 and $\mathrm{n}$.; fails to evacuate the rest of Manchuria, 34, 36, 256 and 11.; makes seven new demands, 34-35, 337; makes six fresh demands, 36 n., 57; aggressive and exclusive policy of, in Manchuria, 36 ; relations with Korea, 42 ff. (see Korea) ; negotiations with Japan, 53-60, 68 and n.; increased activity of, in Manchuria and Korea, 56; military activity of, in the Far East, 5960 and n.; accuses Japan of treachery, 66 ff.; breaks off diplomatic relations with Japan, $6 \mathrm{I}, 68-70$; delays in answering Japanese notes, 68; accuses Japan of violation of International Law, 70-7I; real motive of, in entering protest, 72; claims treaty between Japan and Korea is invalid because made under duress, 73 and n.; view prevails in, that granting of permit to construct submarine cable would constitute breach of neutrality, 78; good effect in, produced by President Roosevelt's Executive Order, 89; sale to, of steamers belonging to the German Auxiliary Navy, 9I and n.; exportation to, of torpedo boats from Germany, 91, 92; purchases vessels in England for use as transports, 93 ; in competition with Japan for the purchase of transports in Holland and Belgium, 93; agents of, negotiate for purchase of cruisers in South America, 94 and n.; agents of, order torpedo craft in the United States, 94 ff.; fails to call attention of United States Government to fact that submarines are being built, II 3 and n.; declaration of, to the United States threatening to treat war correspondents as spies, I I5-I I6; sends similar note to the other Powers, I 16 and n.; notified that rights of American citizens are not waived, $117 \mathrm{n}$.; gives assurances to Great $\mathrm{Bri-}$ tain and United States, II7 n.; provocation for Russian note, 
II7; threatens rights of neutrals, I I9; defends Admiral Alexieff's order, II9; installs wireless telegraphy apparatus at CheFoo, 122 n.; sets adrift submarine mines on high seas, I25126 and n.; makes no denial, 127; M. de Plehve protests against action of the Japanese in laying mines, $127 \mathrm{n}$.; attempts to justify laying of mines, 127128; reply to Russian argument, 128-I30; complaints against, for search and detention of neutral merchantmen, I36-138; pays demurrage and indemnity for detention and seizure of neutral vessels, I37 and n.; releases neutral vessels, I38; declares coal contraband, I38; seizes neutral vessels in the Red Sea, I38-142; searches Prinz Heinrich and confiscates mail bags, I39; agrees to Germany's demands in case of Prinz Heinrich, I40; releases the Malacca, I4I-I42; agrees to instruct officers of Volunteer Navy to refrain from interference with neutral shipping, I4I-I 42 ; fails to convey these instructions, 142 ; requests British Government to convey orders to Smolensk, I42 n.; sinks the Knight Commander, I42I44; sinks other neutral vessels and Japanese merchantmen, I43 n.; orders captains to abstain from sinking neutral vessels, I43 n., I46-147 and n.; requested to make amends for sinking of the Knight Commander, I45; justifies herself, 146 and $n$.; pays indemnity, I47; protests against coal as contraband at West African Conference, 161 n., I69; publishes list of contraband, $163-$ 165; makes no distinction between absolute and conditional contraband, I63, I66; threatens attack upon neutral commerce, I67; violates International Postal Convention and International Law in cases of the Calchas and Cincinnati, I77 n.; replies to British protest, I82; modifies her position as to conditional contraband, 182; gives further assurances to Great Britain 183 ; files protest against British shipments of contraband, $183-184$; disarms the Mandjur, 189 ; proposes that precedent set in case of the Mandjur be followed in case of the Askold and Grosovoi, 206-207 n.; requests internment in case of the Lena, 208; decides in favor of internment of the cruisers at Manila, 2ri; copies British restrictions upon liberty of belligerent warships in neutral ports, 213 n.; not wholly averse to disarmament of belligerent warships in neutral ports, 216; guilty of a long series of outrages, 218 ; expresses regret and promises reparation for North Sea Incident, 219-220, 22I, 226; orders Admiral Rojestvensky to remain at Vigo, 225; accepts principle of International Commission of Inquiry, 225; agrees to issue instructions to Russian fleet securing freedom of neutral commerce, 226 and n.; negotiations of, with Great Britain respecting organization and scope of North Sea Commission, 22823 I ; "Conclusions" of, 235 ; justifies conduct of Admiral Rojestvensky, 236; pays indemnity, 238 ; conditional acceptance by, of Hay Note, 247-248; demands dismissal of Japanese military instructors in Chinese army, 255; reoccupies region west of Liao River, 257; sends Circular Note to the Powers specifying five breaches of Chinese neutrality, 258-259; largely responsible for weakness of China, 268; threatens to absolve herself from her agreement with the Powers by an ex parte decision of all questions relating to Chinese neutrality, 268; issues Imperial Order of Feb. 28, 1904, 269-27I ; agrees to observe certain International Agreements, $270-27 \mathrm{I}$; issues "Instructions" to 
Russian army respecting usages of Continental War, 272-28I ; fails to provide Bureau of Information, 278 n.; a signatory of Hague Convention, 295; allows six weeks of "grace" at beginning of Crimean War, and in 1877,296 ; conduct of, contrasted with that of Japan, 30I n.; accuses Japan of violating Hague and Geneva Conventions, 302, 305; protests against alleged violations of the rules of warfare by Japan, 302, 306; accuses Japanese of mutilation of the dead and wounded, 308-309 and n.; bombards Gensan, 3II, 316 ; accuses Japanese of using lyddite shells, 3I6; charges against, of using dumdum bullets, 317 and $n$.; more regardful of the rights of belligerents than of neutrals, 323 ; violates territorial integrity of China, 328; enters into Agreement of April 28, 1899, with England, 328-329; reply of, to Hay Circular Note of Sept. 6, I899, 330 n.; urges territorial integrity of China, 333; relations of, with France, $334 \mathrm{n}$.; opposes opening of Mukden and Antung to trade, 338; policy of, in China, 339; acknowledges Japan's paramount interests in Korea, 341; negotiates treaty of peace with Japan, 340-359; agrees to evacuate Manchuria, 34I-342, 345-355 ; transfers lease of Port Arthur, railways, etc., to Japan, 342,356 ; cedes southern portion of Sakhalin Island to Japan, 343,346 ; grants fishery rights to Japanese subjects, 343 ; engages to repay Japan expenses for care and maintenance of prisoners, 344 ; sends favorable reply to President Roosevelt's Note suggesting peace negotiations, 349 and $\mathrm{n}$.; rejects four of the twelve Japanese demands, 35I-352; concludes peace with Japan, 34I355.

Russian Advance, 4, 356 and $n$.
Russian fleet at Port Arthur, 138, 204.

Russo-Chinese Bank, activity of, $3 \mathrm{n}$.; organization of, Io; terms of "Agreement" with China relating to, 13-14, 24, 29; Russian demands on China regarding, 24 , 25,35 ; proposed agreement between Russia and China relating to, 335 .

Russo-Korean Bank, 47.

Russo-Turkish War, questions relating to, 148 n., 3I5 n.

Russo-Japanese War, causes of, I61,67 ; negotiations leading up to, 52-60, 68 and n.; severance of diplomatic relations, 59-6r, 69 ; outbreak of war, $62-70$; declaration of, 66; conduct of the United States during, 78-90; gives rise to several new questions in International Law, II5, I25; important questions bearing upon the rights of neutrals arising during, 136; an important epoch in the history of neutral rights and obligations, I60; important issues raised during, I88; writes a new chapter of International Law, 216; the most sensational incident of, was the North Sea outrage, 2I7; one of the most important and difficult problems arising during, that of maintaining neutrality and integrity of China, $246 \mathrm{ff}$.; relations of the belligerents during, 295-325; character of the war, $301,308,323$.

Ryeshitelni, case of the, 205, 258263 and notes.

Saigon, used as a base of supplies for Baltic Fleet, 193 and n., 196; the Diana seeks refuge at, 204.

Sakhalin, 6, 309, cession of southern half of, to Japan, 343,346 , $35 \mathrm{I}-356$.

Salisbury, Lord, on open door in China, $328 \mathrm{n}$.; communication of Mr. Choate to, 33I.

Sanitation, Japanese, 29I $\mathrm{n}$.

Santissima Trinidad, case of the, IOO-IOI and $n$. 
Scandia, seizure of the, $142 \mathrm{n}$.

Scandinavian countries (see Denmark and Norway-Sweden).

Seizures, Russian, of neutral vessels in Red Sea, I36-142, I48, I5I-I53; in the Pacific Ocean, 143-144.

Seoul, 40, 43, 44, 45, 46, 47 .

Settlements, foreign, in Manchuria opposed by Russia, 36 n., 58 and n., $338 \mathrm{n}$.

Shanghai, 78; Russian warships interned at, $188,205-206,259,267$.

Shang-tung Peninsula, Germany secures privileges in, 15, 204, 327.

Sheng-King, province of, I8, 33, $34 \mathrm{n}$.

Shimonoseki, Treaty of, 6.

Siberia, 4, 256 n., 298, 352, 356.

Sick and wounded, the, Russian "Instructions" relating to, 272 ff.; treatment of, 276, 280-28I, 284, 291 and n., 307 n.; Japanese treatment of, 319-323, 324; Russian treatment of, 322 and $n$.

Sieges, Hague Regulations on, 307 n. ; examples of, 3I5 n.

Sinking of neutral prizes by Russians, I36, I42-I 47 and notes, 156-159; sinking of Japanese merchantmen, 143, 299-30r.

Smith and Sibley, on the case of the Allanton, $\mathrm{I} 72 \mathrm{n}$.; on the case of the Cheltenham, I73 n.; on cases analogous to North Sea Incident, 240-24I $\mathrm{n}$.

Simolensk, the, searches and seizes neutral vessels in the Red Sea, I38; confiscates mail of Prinz Heinrich, 139; appears in South African waters, I42 n.; legality of commission of, $\mathrm{I}^{2} \mathrm{n}$.

Sonntag, the, fired upon off Dogger Bank, $223 \mathrm{n}$.

Southampton, Premier Balfour's speech at, 226-228.

Spain, sends unfavorable reply to Hay Note, 247 n.; permits Baltic Fleet to coal at Vigo and exceed twenty-four-hour rule, I9I ; protests against furnishing arms and ammunition to insurgents during Spanish-American War, 3IO n.
Spanish-American War, questions relating to, 65 n., $79-80$, 124 n., I 54 n., I68, 192 n., 296-297 and n., 304 n., 310 n., 315 n., 323, 325-327.

Speyer, M., Russian representative at Seoul, 47.

"Spheres of interest" or "influence" in China, 327, 330, 33I, 339.

Spies, war correspondents to be treated as, II6-II7; Bismarck's threat to treat balloonists as, II6 n.; definitions of, I2I and n., 279; persons transmitting wireless messages not to be considered, $135 \mathrm{n}$.

Stead, Alfred, on Japanese treatment of sick and wounded, 32I.

St. Kilda, sinking of the, I43 n., I47 $\mathrm{n}$.

Stoessel, General, complains of bombardment of Red Cross Hospitals, 305.

Story, Judge, opinion of, in case of Santissima Trinidad, 100 and n.

Stowell, Lord (Sir W. Scott) opinion of, on right of visit and search, I49; on convoy, I50 n.; on destruction of prizes, $156 \mathrm{n}$., I $57 \mathrm{n}$. ; in the case of the Imina, I72; in the case of the Nancy, I $72 \mathrm{n}$.

Suez Canal, 138, I39, I52 and n., I89, I9I.

Suez, Gulf of, 138 .

Subjects of enemy state found in belligerent territory at outbreak of war, Russian rules relating to, 269, 295, 297; Japanese instructions relating to, 282-284, 295-297; conditions under which they may be considered belligerents, 272; a belligerent has the right to expel, in extreme cases, 298-299; recent practice, 299 and $n$.

Submarine Cables (see Cables).

Submarines, exported over land from Germany to Russia, 92; contracts for construction of, in United States, 94; case of the Protector, 94-95, II 2-II4; case 
of the Fulton, 95, II2 n.; statement of Secretary Loomis regarding, 95; rumors of the sale, construction, or exportation of craft in or from the United States, 95-96; case of the Caroline, 96 ; modern usage seems to permit sale of, III; classed as contraband, III; neutrals not free from responsibility in such cases, Ir2; license in the use of, I30 and n.; torpedo-boat destroyers interned at Tsing-tau. 204; alleged attack of Baltic Fleet by Japanese torpedo-boats, 221-222, 227, 235-237, 238 n., 243.

Switzerland, neutralization of, 248 .

Taft, Secretary, draws distinction between disablement of a vessel caused by accident and damage caused in battle, $209 \mathrm{n}$.

Takahira, Mr., Japanese Minister at Washington, $8 \mathrm{I}$ and $\mathrm{n} ., 260$ n., 298, 307, 349 .

Talbot, the, rescues Russian sailors at Chemulpo, 75 and $n$.

Talien-wan (Dalny), 12, 259; leased to Russia, 15, 47, $256 \mathrm{n}$.; made an open port, 327 n., 330 n.; transferred to Japan, 342, $35 \mathrm{I}$.

Terek, the, sinks neutral vessels, 147 n.; interned at Batavia, 2 ro $\mathrm{n}$.

Thea, sinking of the, 144, 156, $173 \mathrm{n}$.

Three-Mile Limit, necessary to enlarge, 127-128, I32; laying of mines outside of, $130-13 \mathrm{I}$; states a right to lay mines within, I30; history of, $132-133$; United States attempts to obtain extension of, I33 n.; The Institute of International Law seeks to obtain extension of, r 34 n.; questions relating to, should be referred to next Hague Conference, 134.

Tientsin Convention, terms of, $4 \mathrm{I}$; ignored by China, 43 .

Torpedo Boats (see Submarines).

Trans-Manchurian Railway (see Chinese Eastern Railway).
Trans-Siberian Railway, 6, 9, II, I4.

Transports, purchase of, in England, Holland and Belgium, 93.

Treachery, Russian charges of, against Japan, 66; conduct of both belligerents honorable in abstaining from, 30r.

Treaties (see also Agreements, Alliances, and Conventions) :

Aigun (1858), 5 .

Arbitration Treaty of Hague Conference (1899), 347.

Berlin ( 1878$), 148 \mathrm{n}$.

Commercial Treaties: between United States and China, 338; between Japan and China, $338 \mathrm{n}$.

Japanese-Korean (r904), 73.

London (r84I), r4r n., $148 \mathrm{n}$.

London Conference (1871), I $48 \mathrm{n}$.

Nerchinsk (I68I), 4.

Paris (1856), I4I n., I48 n.

Peking ( 1860$), 5$.

Portsmouth (1905), 341-360.

Shimonoseki (1895), 6-7.

Washington ( 1870 ), 83 .

Treaties, whether valid if made under duress, 73-75.

Truces for burial of the dead, customary to grant, 304 and $n$.

Tsing-tau, Russian vessels seek refuge at, 204, $207 \mathrm{n}$.

Tsushima, battle of, 194 .

Tsushima Islands, 6, 37 n., 39, 42.

Tumên River, mining concession to Russia on, $45,50-51$.

Turkey, rumors of purchase of ships by, for Russia, 94; fails to protest against passage of Straits by vessels of Russian Volunteer Navy, I39; enters into convention with Russia in I89 1 to permit passage of Straits by Volunteer Navy, I 48 $\mathrm{n}$.; allows days of grace in 1877 , 296.

Twenty-four-hour rule, 88 , 212$2 \mathrm{I} 6$; application of, in case of the Mandjur, I88-189; in case of the Novik, 204; in case of the Diana, 205; in case of the Askold and Grosovoi, 205-206; in case of the Lena, 207; in case 
of the Terek, $210 \mathrm{n}$.; in case of the Russian cruisers at Manila, 209-210.

Uchida, Mr., views of, $8 \mathrm{I}$.

Ultimatum, usually precedes war, 66.

United States, protests against the Alexieff-Tsêng Agreement, 19; protests against Russian demands on China regarding Russo-Chinese Bank, 24, 26, 335336; protests against Russia's seven new demands, 36,337 ; conduct of, in respect to its neutral rights and duties, 78 90 ; a clear and consistent record, 78,89 ; application to for construction of submarine cable, 78; "American meddling," 79; manifests interest in the fate of China, 79; sympathy for Japan, 80 ff., 339; citizens of, desire to enlist in Japanese army, 80; mass meeting in New York, 80-8I n.; failure of, to prevent departure of citizens for the Orient not a violation of neutrality, 83 ; bound to prevent fitting out, arming and equipping of warships intended for belligerent service, 84; fully discharges neutral obligations, 87 ; issues Neutrality Proclamation, $87-88$; Russian and Japanese agents at work in, 94 ; rumors of sale, construction in or of exportation of torpedo craft from, 9596; agrees to abide by Rules of Treaty of Washington, $98 \mathrm{n}$.; classes torpedo craft as contraband, III; not responsible in case of Protector, II2; receives note from Count Cassini threatening to treat war correspondents as spies, I15-II6 and n.; decides to defer protests, II7; notifies Russia that rights of American citizens are not waived, II7 n.; receives assurances from Russia, II7 n.; institutes investigation to ascertain extent of mines, 126-127 n.; decides not to participate in work of destroying mines, 127 n. ; attempts to secure extension of three-mile limit, I33 n.; position of, in respect to convoy, I5I n.; on search of mail steamers, $\mathrm{I} 53$; on destruction of prizes, 158 n.; issues instructions regarding search of mail bags, I54 n.; protests against decision of the Russian prize court in case of the Arabia, I65 n.; semi-official protest of, against Russian list of contraband, I67 and n.; sends Circular Note on Russian list of contraband, I68-170; enters conditional protest in case of Knight Commander, I74 n.; asks for release of Arabia, 176; requests investigation in case of the Cincinnati, I77 n.; protests in case of Arabia, 179-182; complains of trade in contraband between Great Britain and Confederacy, I84 $\mathrm{n}$.; position of, in respect to right of neutral to trade in contraband, $185-186$ and n.; adopts British restrictions upon liberty of belligerent warships in neutral ports, $213 \mathrm{n}$.; sends Hay Note (Feb. Io, I904), 246-247; receives favorable replies, $247-248$; outcry in, owing to proclamation of martial law at Niu-Chwang, 257 and n.; guilty of two violations of neutrality of territorial waters during Civil War, $262 \mathrm{n}$.; calls attention of China to Russian charges of violation of neutrality, 264 ; suggests Conference of the Powers, 268; "days of grace" allowed by, at beginning of Spanish-American War, 296297 and n.; acts in behalf of destitute Japanese in Siberia, 298 and n.; signs the first Declaration of the Hague Conference, 318 n.; unable to obtain names of Japanese prisoners, 322 n.; relations with England as affected by the Far Eastern Question, 325-34I; acquires Philippine Islands, 327; issues famous Hay Circular Note (Sept. 6, I899), 329-33I; policy 
of, in China, 33I-332; second Circular Note of (July 3, I900), 332 ; acts in harmony with England and Japan, 333 and n., 335; makes representations to China, 334-335; disclaims all knowledge of negotiations leading up to Anglo-Japanese Alliance, 336337 n.; concludes commercial treaty with China, 338; interests of United States and Great Britain in the Orient identical, 331,338 n., 339-340; policy of, in the Orient, 339-340; proclaims neutrality and administrative entity of China, 338 ; relations of, with Great Britain as affected by the war, 339; sympathy of, with Japan, 339; protests against Russian doctrine of contraband, 339 ; sends identical note to Russia and Japan, urging peace negotiations, 347-348; selected as place of meeting for the Peace Conference, 349.

$U$. S. v. Quincy, case of the, Ior, I03, $107 \mathrm{n}$.

Unneutral service, no question of, in case of the Haimun, II6 n.; in case of the Cheltenham, I73 $\mathrm{n}$.

Use of neutral territory for military purpose (see Base of $o p$ erations).

Uti possidetis, rule of, 352 .

Variag, crew of, rescued at Chemulpo, 75, 77 n.; violated parole, $207 \mathrm{n}$.

Venezuela, boundary dispute with England, 325.

Vessels, intended for belligerent service (see also Warships), fitting out, arming, etc., prohibited by the United States Neutrality Laws and British Foreign Enlistment Acts, 99 and $\mathrm{n}$.; building and construction of, prohibited by British Foreign Enlistment Act of 1870 , 100 and $\mathrm{n}$.; mere contraband if built or sent with animus videndi, roo and $\mathrm{n}$.; a proximate hostile expedition if dispatched with ani- mus belligerandi, 100 and $\mathrm{n}$.; older English doctrine inadequate, I03-104; neutral state bound to use due diligence to prevent not only fitting out, arming, etc., but also construction, sale and exportation of, 106 and $n$.; argument in favor of this view, 106-107 and n.; difficult to distinguish between such vessels and others, 106, 109 and n.

Vessels, neutral (see Merchantmen).

Vicksburg, the, at Chemulpo, 70 n., 75-76 n.

Vigo, Baltic Fleet at, 19I, 22I, 225, 226 n., 229 n.; Russian inquiry at, 233.

Visit and Search, right of, 136, 148-156; exercise of, in case of mail steamers, perhaps justifiable, I39; by Russian Volunteer Navy, I4I and n.; opinion of Lord Stowell on, 149; Premier Balfour on, I49 and n.; limitations on, I49-150 n.; resistance to, entails confiscation, I49-150 and n.; right of Peterburg to search the Malacca, I5I-153 and $\mathrm{n}$.; as applied to mail steamers, I53-156; modern usage relating to, I54 11.; Prinz Heinrich subject to, I55; violated by Russia in cases of Calchas and Cincinnati, $\mathbf{1 7 7} \mathrm{n}$.

Vladivostok, acquisition of, 5-6, 9-1 I, I4-1 5, I76 n., I90, 193, I96, 300 ; bombardment of, 31 I, 316 .

Vladivostok squadron, sinks neutral prizes, 136; inflicts damage upon Japanese transports, I38; sinks Thea and Knight Commander, I44; captures neutral vessels, I7I, I73.

Volunteer corps, conditions under which they may be considered as belligerents, 272 ; must wear distinctive emblem, 272, 307-308. Volunteer Navy, Russian seizure of neutral vessels in Red Sea by, I36, I38; status of, I4I and n., I48 and n.; Russia agrees to instruct officers of, to refrain from interference with neutral shipping, I4I ; subsequent seiz- 
ures by, I42 and n.; the Lena, a cruiser of, 207.

Waeber, M., Russian representative at Seoul, intrigues of, 43 n., 47.

Waima incident, the, $242 \mathrm{n}$.

War, an abnormal relation, 62 , II8; effect of declaration or outbreak of, 62; preceded by negotiations and ultimatum, 6566 ; justice or injustice of, $67-$ $68 \mathrm{n}$.

War correspondents, status of, II9-12I and notes, 277; and wireless telegraphy, 12I ff.

Warfare, laws of (see also International Law and Neutrality), forbid laying of submarine mines on high seas, 128-130 and $n$.; permit use of mines in territorial waters, 130, 132; fundamental law of, 253; violated by England during Boer War, 295 n. ; criticism of Russian methods of, 299; violated by the Germans during Franco-Prussian War, $3 I 5$ n.; fairly well observed by both belligerents, 323 .

Warfare, alleged violations of, by Russia: Sinking of Japanese merchantmen, 299-30I; use of Chinese clothing, 307-308; mutilation of the dead and wounded, 308-309; enlistment of convicts, 309-3II; bombardment of an undefended coast town, 3II; use of dumdum bullets, 3 I 7 .

Warfare, alleged violations of, by Japanese: Firing on Red Cross train, 30I-303; treachery in use of white flag, Red Cross flag, etc., 303-304; firing on hospital ships, 305-306; firing upon quarantine station, 306 ; mutilation of the dead and wounded, 308 309 and $n$.; bombardment of an undefended coast town, 3 II and n.; use of lyddite shells, 316 .

Warfare on land, Regulations of Hague Conference respecting (see also Hague Conference, Regulations of: Russia agrees to observe, 270, 27 I n.; Art. I of, $27 \mathrm{I}$ n.; question as to binding character of these rules, 27I272 n. ; compared with Russian "Instructions," 272 n., 275 n., 278 n., 279 n., 285 n., 286 n., 287 n. ; Japan and Russia signatories of, 295; "Instructions" to Russian army, 272-28r ; Japanese and Russian rules of, 269 295; Russian rules of, as embodied in Imperial order (Feb. 28, 1904), 269-27 I ; in "Instructions" to Russian army respecting usages of Continental War, 272-28I ; Japanese rules, as embodied in Imperial Ordinance (Feb. 9, 1904), 28r-288; Instructions to the general Government of Tai-wan (Feb. Io, 1905), 282-283; note to schoolteachers of Japan (Feb. ro, 1904), 283; Instructions to heads of religious sects (Feb. I9, 1904), 283-284; regulations relative to the treatment of prisoners of war, 284-2 $S_{5}$; Japanese rules as embodied in additional instructions (Feb. I9, I904), 285-287; additional instructions (Sept. Io, I904), 285 n. ; "Postal Regulations for Prisoners of War" (Mar. 3, I904), 287-288; Imperial ordinance (Feb. 2I, I904), relative to "Bureau of Information for Prisoners of War," 289-290; Japanese "Regulations" relative to clearing of the battlefield and the interment of the bodies upon said field, 29I-294.

Warfare (naval), conditions of, changed, Ior ; questions relating to, should be referred to coming Hague Conference, I34; on question of naval bombardment, 306-307 n., 3II-3I6 and notes.

Warships (see also Vesscls intended for belligerent service), movement to present to Japanese Government, So, 84 ; fitting out, arming, or equipping of, forbidden, 83 ; doctrine of intent as applied to, 86-87; intended for belligerent service, 9III5: ordered by Japan in England, 93; negotiations for pur- 
chase of, in South America by Russian and Japanese agents, 94 and $n$.; sale of, by a neutral state, 97 and n.; neutral state bound to use due diligence to prevent, 97-98; approximates a military expedition, II2; right of visit and search of, r48-r49; important issues respecting rights and privileges of, in neutral ports and waters, raised during Russo-Japanese War, I88, 204; supply of coal to, in neutral ports and waters, 190-203; divergence in practice in matter of furnishing coal to, 198, I99200 ; 210-216; Proclamation of Governor of Malta forbidding coal to, 200; increasing importance of coal to, 200-203; case of the Mandjur, I88-189; the Novik and Czarevitch, 204; the Diana, 204-205; the Askold and Grosovoi, 205-206; the Lena, 207-208; the three Russian cruisers at Manila, 209-210, 2 I5 $\mathrm{n}$.; conditions of right of asylum of, in neutral ports, 2ro and $\mathrm{n}$. ; instances of prohibition to enter neutral ports, I99 n., 2IO-2II n.; views of authorities on, $210-212$ and n., 262-263; length of stay in, 213-216; repairs allowed, 213-2I5; rights of, on the high seas, 242245; Premier Balfour on, 227228; Count Cassini on, 242-243; views of naval officers on, 243; Prof. Holland on, 244; Japan demands surrender of Russian, interned in neutral ports, 35I ; refused by Russia, 35I-352.

Washington, treaty of, 83 ; First Rule of, 97-98 and n., IOO, IOI, 106, 112.

Waters, neutral, rights of belligerent armed vessels in, 188 , 204; use of French territorial waters by Baltic Fleet, 190-203; supply of coal in, 190-203, 213214.

Waters, territorial, rights and duties of belligerent warships in, $262-263$; instances of violation by, 262 n.; Walker on, 262-263; case of the General Armstrong, 262-263 $\mathrm{n}$.

Webster, Daniel, in the case of the Caroline, 262.

Wei-hai-wei, II7, I25 n., I26 n., I32 n.; leased to Great Britain, I5 and n., 328.

Wireless telegraphy, use of, in neutral waters or on high seas, II5-II9, I2I-I25; apparatus of, on board the Haimun, II7; invention of, makes it harder to control war correspondents, 122; station at Che-Foo, I22 n., 266267 ; on neutral soil, 122-123 and $\mathrm{n}$. ; interference with messages might be permitted, 123; seizure and confiscation of apparatus as contraband, 123 and n.; proposal to exclude vessels of correspondents from zone of warlike operations, I23-I24 n.; proposal to prohibit emission of waves, I24 n. ; rules of Institute of International Law on, I35 $\mathrm{n}$.

Wirenius, Admiral, violates neutrality of Egypt, 189; stay of, at Jibutil, I89.

Witte, M., Russian peace plenipotentiary at Portsmouth, 349 and n., 350 n., $35^{2-353}$ and n., $354 \mathrm{n}$.

Wounded, the, Russian "Instructions" on, 272-273; treatment of, $276,280-281,284,291$ and n., 307 n.; fired upon, 305 ; mutilation of, 308-309 and n.; Japanese treatment of, 319-322, 324; Russian treatment of, 322 and $n$.

Yalu River, crossing of, by Russian troops, 34, 7 I n.; timber concessions to Russia on, 45; Russians cut timber at, $5 \mathrm{I}$.

Yamagata-Lobanoff Protocol, terms of, $45-46$; violation of, by Russia, 46-47.

Yong-am-po, 34, 50, 5 I.

Zone, neutral zone in Korea proposed by Russia, 56-59; in Manchuria proposed by Japan, 57; of warlike operations, $123 \mathrm{n}$., I $24 \mathrm{n}, \mathrm{I} 3 \mathrm{I}$. 


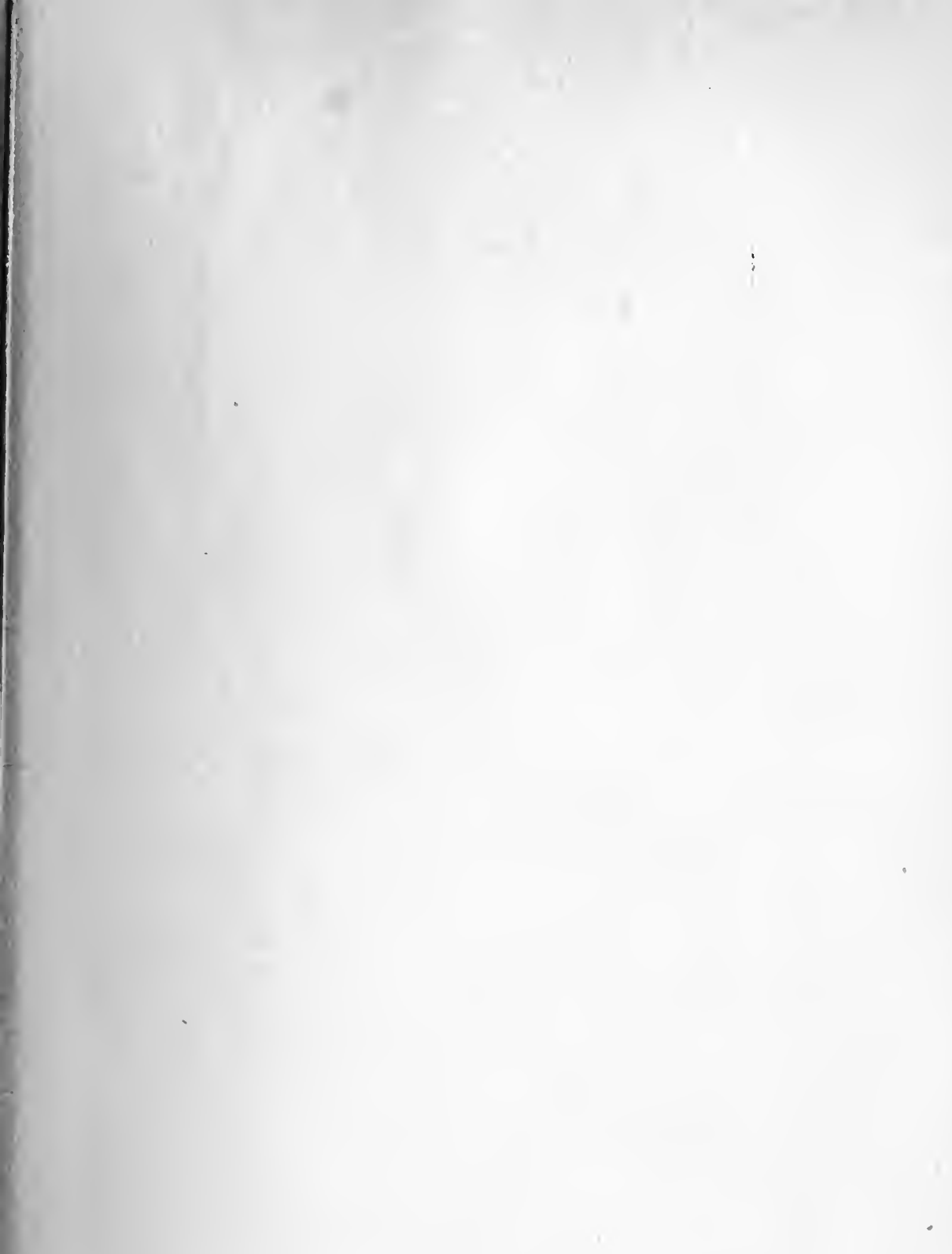
\begin{tabular}{|c|c|}
\hline+0 \\
\hline
\end{tabular}
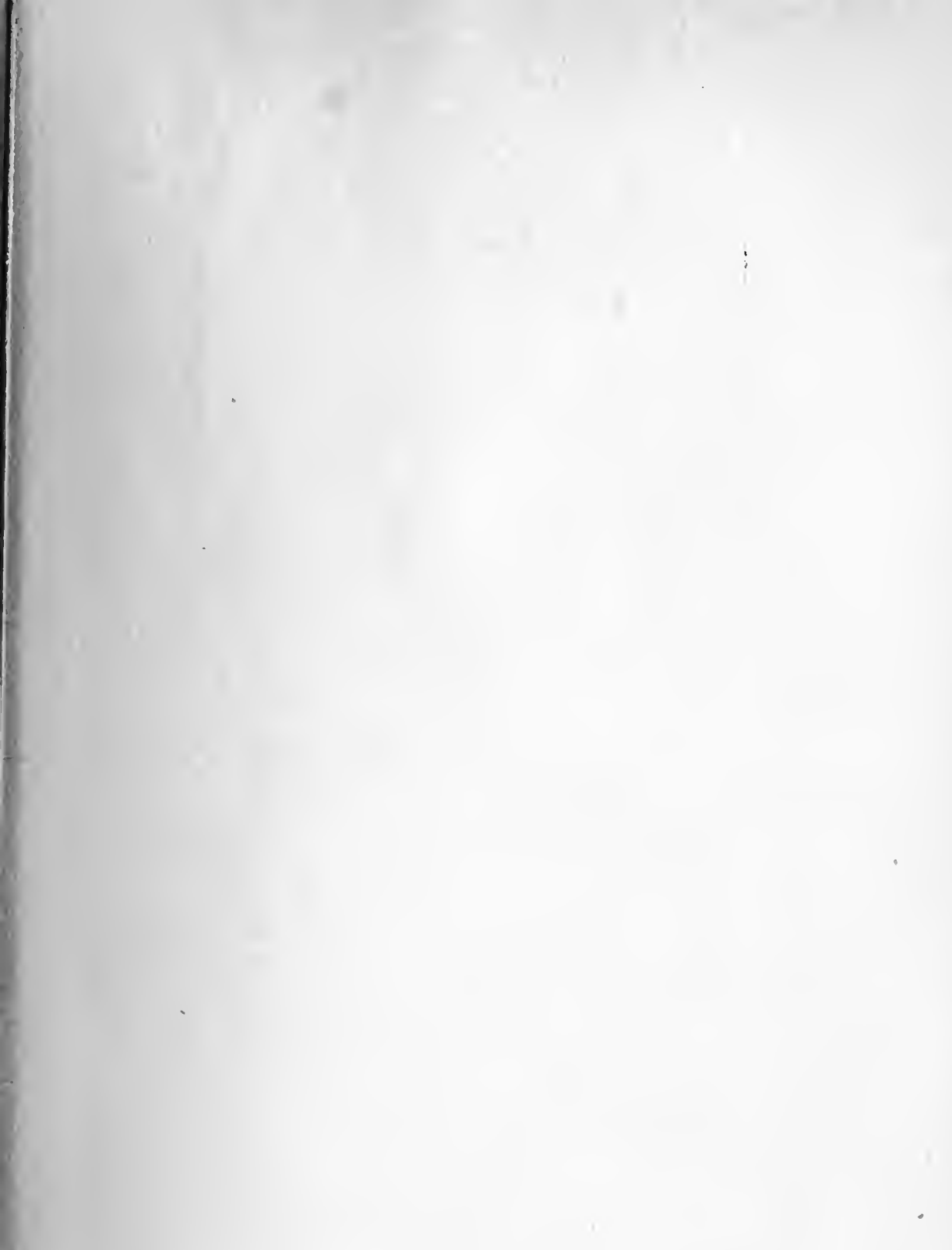



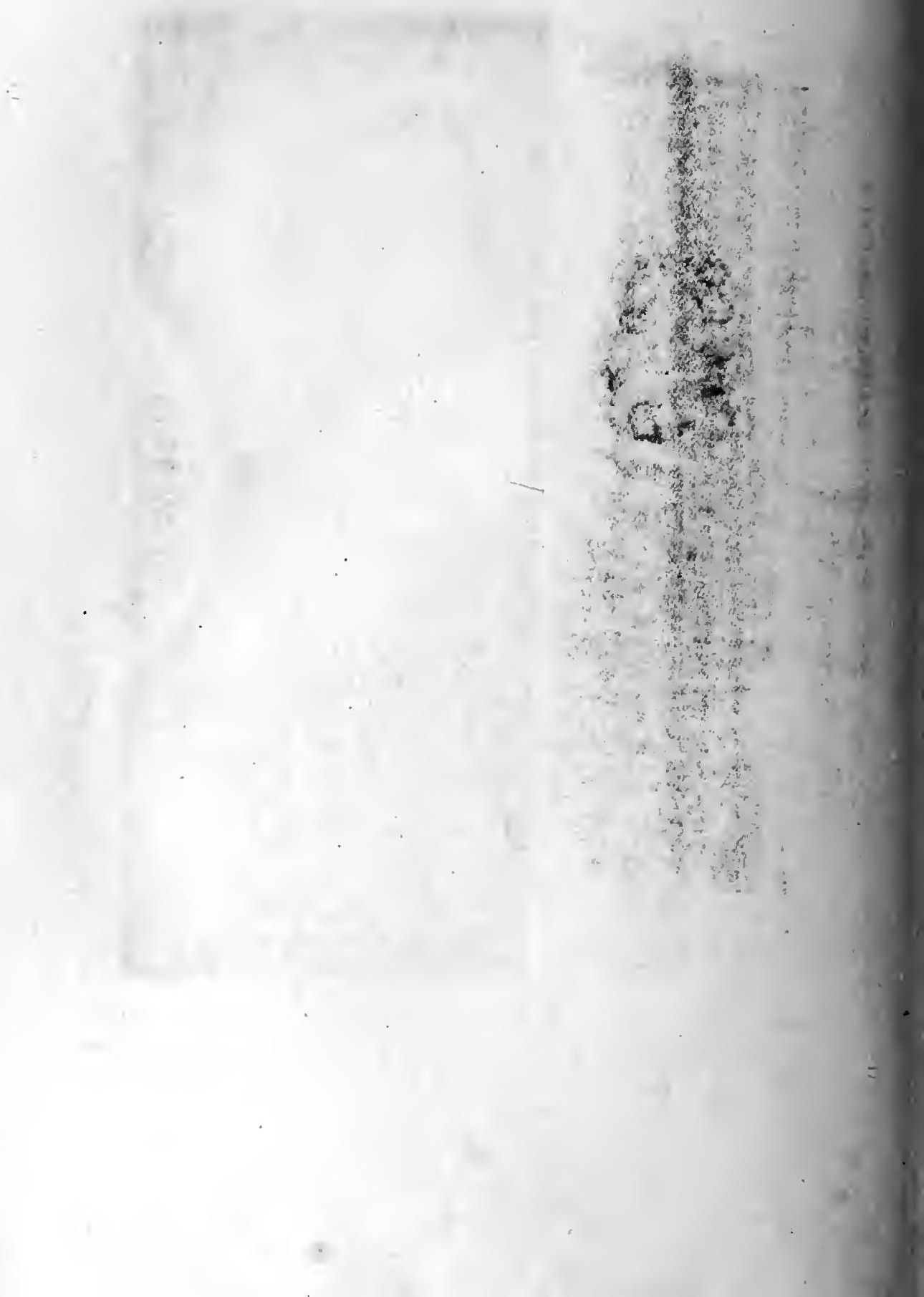




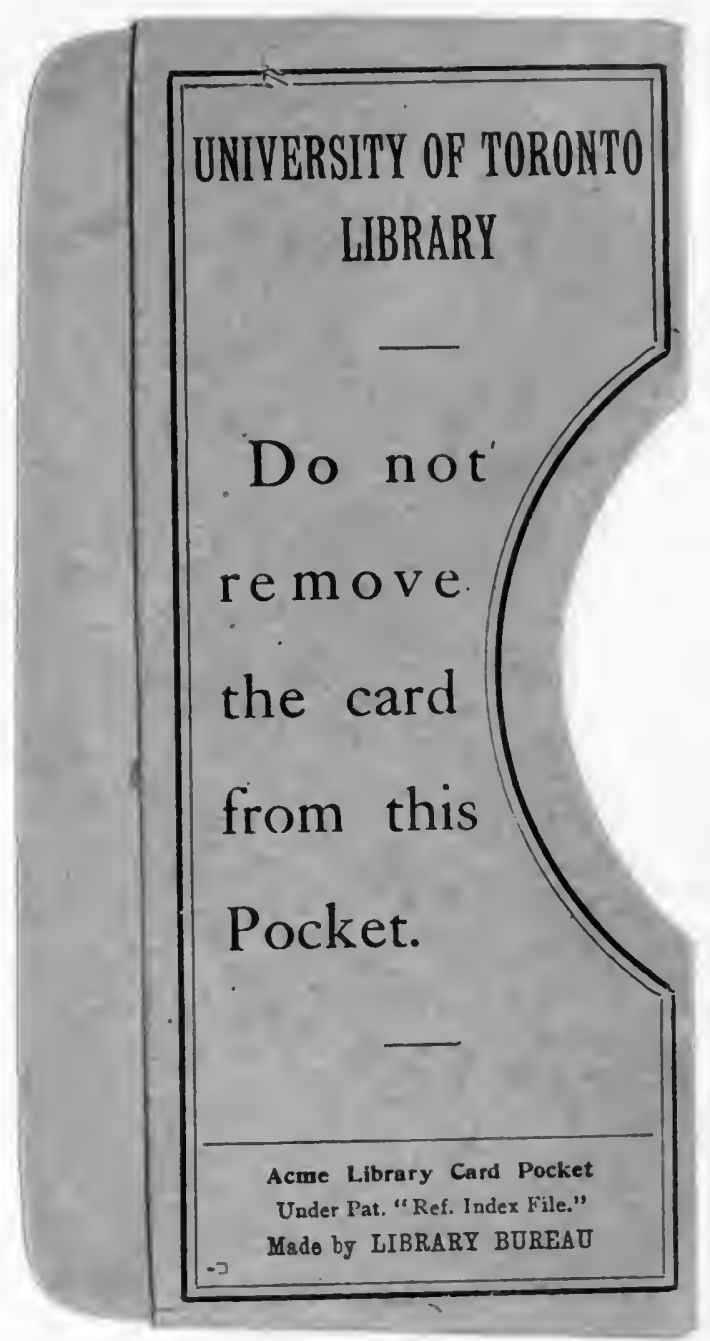


